\title{
Investigation of selenium and arsenic in coal-mining associated rocks and sediments using ultrasonic and sequential extractions techniques
}

Innocent Pumure

West Virginia University

Follow this and additional works at: https://researchrepository.wvu.edu/etd

\section{Recommended Citation}

Pumure, Innocent, "Investigation of selenium and arsenic in coal-mining associated rocks and sediments using ultrasonic and sequential extractions techniques" (2008). Graduate Theses, Dissertations, and Problem Reports. 4417.

https://researchrepository.wvu.edu/etd/4417

This Dissertation is protected by copyright and/or related rights. It has been brought to you by the The Research Repository @ WVU with permission from the rights-holder(s). You are free to use this Dissertation in any way that is permitted by the copyright and related rights legislation that applies to your use. For other uses you must obtain permission from the rights-holder(s) directly, unless additional rights are indicated by a Creative Commons license in the record and/ or on the work itself. This Dissertation has been accepted for inclusion in WVU Graduate Theses, Dissertations, and Problem Reports collection by an authorized administrator of The Research Repository @ WVU.

For more information, please contact researchrepository@mail.wvu.edu. 
Investigation of selenium and arsenic in coal-mining associated rocks and sediments using ultrasonic and sequential extractions techniques

\author{
Innocent Pumure
}

Dissertation submitted to the Eberly College of Arts and

Sciences at West Virginia University in partial fulfillment of the requirements for the degree of

Doctor of Philosophy

in

Chemistry

Ronald B. Smart Ph.D., Chair

Fred L. King, Ph.D.

Lisa Holland, Ph.D.

Bjorn C. Söderberg, Ph.D.

John J. Renton, Ph.D.

C. Eugene Bennett Department of Chemistry

Morgantown, West Virginia 2008

Keywords: Mountaintop removal/Valley Fill coal mining, selenium, arsenic, principal component analysis 


\section{Abstract \\ Investigation of selenium and arsenic in coal-mining associated rocks and sediments using ultrasonic and sequential extractions techniques}

\section{I nnocent Pumure}

Ultrasound extraction was used to compare the accelerated release rates of arsenic and selenium from pulverized rocks associated with mountain-top removal/valley fill method of coal mining. The kinetic studies demonstrated that the release rates are dependent on rock lithology as well as the total concentrations found in the rocks. Se (IV) was found to be stable under ultrasonic irradiation $\left(200 \mathrm{~W} / \mathrm{cm}^{2}\right)$ but As (III) was quickly oxidized to As (V). Rocks such as BT700 were found to have more Se (IV) compared to Se (VI) and others such as BT571 were found to contain more Se (VI) than Se (IV).

Continuous application of ultrasound energy at $200 \mathrm{~W} / \mathrm{cm}^{2}$ for 20 and 25 minutes was found effective in the extraction of bioavailable selenium and arsenic from $1 \mathrm{~g}$ of pulverized rocks, respectively. The amounts extracted were similar to the concentrations obtained in the combined water and phosphate buffer fractions from the sequential extractions.

Selenium concentration in stream at MT15 and MT18 sampling points decreased over a period of seven years but remained almost constant at MT 34B during the same period. The sediment MT 34B had the highest amount of extractable selenium and arsenic and both elements appear to be closely associated with organic matter. Most of the selenium in the MT 34B sediment was Se (IV).

The reduction of Se (VI) through Se (IV) occurs at $\mathrm{pH} 7$ and $\mathrm{pH} 4$ when reacted with kaolin and combined HA-kaolin mixtures. HA alone can reduce Se (VI) at $\mathrm{pH} 4$ but not at $\mathrm{pH} 7$.

A chemometric analysis of extraction data using principal component analysis suggested that released selenium is associated with 14 Á d spacing clays and extracted arsenic is associated with illite in rocks analysed. 


\section{Dedication}

To my lovely wife, Patience and wonderful children, Tapiwa and Tatenda for lightening up my days and for always being there for me .... 


\section{Acknowledgements}

I am greatly indebted to you Dr. Ronald B. Smart for your unwavering support throughout challenging and exciting phases during my stay at WVU. I truly and earnestly appreciate your sustained guidance and encouragement. Through your leadership, I have gained a lot of enthusiasm, knowledge and expertise in as far as critical thinking, synthesis and broadening of research ideas is concerned. I will always cherish this invaluable experience.

I also want to extend my heartfelt gratitude to all the members of my Examining Committee Dr. Bjon Söderberg, Dr. Fred L. King, Dr. Lisa Holland and Dr John J. Renton for taking time out of their busy schedules to read through the dissertation and for asking stimulating questions and providing insightful suggestions. Dr. Smart, Dr. King and Dr. Holland I can never thank you enough for finding time to write recommendations letters during my endeavor to secure employment. Dr Renton, I will never forget the one-on-one Geology 101 tutoring that helped me immensely in the understanding of principles behind the geology of minerals.

I want to thank my mother, Enilia Pumure, for always believing and supporting me throughout my career and my late father, Canaan Tapfumaneyi Pumure, for sowing the seeds of hard work, perseverance and determination in me. Of special mention are family friends Klaas and Reiny van Twillert and my in laws Timothy and Benedicta Kondo for helping with travel arrangements making my dreams come true.

I greatly appreciate the work of three undergraduate students who helped in the analysis of samples; Jason Turner, Kristen Statler and Dan Carrier. 
I also wish to express my sincere gratitude to the United States Geological Survey -State Water Resources Institute program for financial assistance, Grant No. 06HGR0127 and the West Virginia Geological and Economic Survey for providing pulverized coal -associated rock samples. 


\section{Table of Contents}

$\begin{array}{ll}\text { Abstract } & \text { ii }\end{array}$

Dedication $\quad$ iii

Acknowledgements $\quad$ iv

Table of Contents vi vi

List of Figures $\quad$ X

List of Tables $\quad$ xiv

Chapter 1: Mountaintop Removal/Valley Fill Coal Mining and the release of Selenium and Arsenic into Surface Water 1

$\begin{array}{ll}\text { Chemical speciation of arsenic and selenium } & 1\end{array}$

Selenium speciation $\quad 1$

Arsenic speciation $\quad 5$

Selenium and arsenic toxicity to fish and other wildlife 5

$\begin{array}{lr}\text { Release of arsenic and selenium from waste rocks } & 9\end{array}$

$\begin{array}{ll}\text { Environmental impacts of released selenium and arsenic } & 10\end{array}$

$\begin{array}{ll}\text { Extraction of selenium and arsenic from solid samples } & 13\end{array}$

$\begin{array}{ll}\text { Ultrasound extraction } & 17\end{array}$

$\begin{array}{lr}\text { Sample collection } & 18\end{array}$

Chapter 2: Accelerated aqueous leaching of selenium and arsenic with selenium speciation using ultrasound extraction 24

$\begin{array}{ll}\text { Introduction } & 24\end{array}$

$\begin{array}{ll}\text { Ultrasonic first order kinetics } & 25\end{array}$

$\begin{array}{ll}\text { Experimental } & 26\end{array}$ 
Calorimetric power measurements

Power measurement for $1.905 \mathrm{~cm}$ diameter probe tip

Power calculation for a $0.3 \mathrm{~cm}$ diameter probe tip

Selection of an appropriate probe tip

Procedure for hydride generation AAS

Procedure for total As and Se analysis using Graphite furnace AAS

Procedure for microwave digestion

Results and Discussion

Mineralogical examination of pulverized rocks

Comparison of extraction methods

Effects of ultrasonic power on the speciation studies for $\mathrm{Se}$ (IV)/ Se (VI) and As (III)/As (V)

\section{Chapter 3: Sonochemical extraction of arsenic and selenium from coal mining associated rocks: Estimation of bioavailable concentrations}

Introduction

Experimental

Materials and Methods

Sequential extraction

Results and discussion

Batch sonicated extracts

Particle size 
Comparison of bioavailable fractions determined with sequential and ultrasound extractions

Summary

\section{Chapter 4: Distribution of selenium and arsenic in water and sediment} Samples

Introduction

Experimental

Sediments and water samples

Pretreatment of kaolin and silica gel

Sorption of selenium and arsenic compounds on kaolin and silica gel

Catalytic reduction of selenate on kaolin

Results and discussion

Sequential extraction of selenite in sediments

Sequential extraction of total selenium in sediments

Sequential extraction of total arsenic in sediments

Background samples

Sorption of arsenic and selenium on kaolin and silica gel

Selenate sorption on kaolin and associated redox kinetics 
Chapter 5: Interstitial location of selenium and arsenic in coal-associated rocks

Introduction

Structures of phyllosilicate clays

Principal component analysis

Sampling

Experimental

Results and discussion

Primary PCA analysis

Secondary PCA analysis

Scatter and Contour plots

Location of selenium and arsenic in the mineral lattice

Ionic substitution

Summary

Future studies

Appendix 1A: Derivation of the differential first order kinetic equation

Appendix 1B: Approximation of $\mathrm{B}_{\infty}$ using the Kezdy- Swinebourne method

Appendix 1C: $\mathrm{X}$ ray diffraction analysis of rocks

Appendix 1D: Results from secondary PCA 


\section{List of Figures}

Figure 1: $\quad$ Step by step overview of mountaintop removal /valley fills Procedure

Figure 2: $\quad$ A view of the 1929-acre mountaintop removal site in Bob White, Boone County, W.Va.

Figure 3: $\quad$ Eh-pH diagram for dissolved selenium species $\quad 6$

$\begin{array}{lll}\text { Figure 4: } & \text { Eh-pH diagram for dissolved arsenic species } & 7\end{array}$

Figure 5: Bioavailability of species sorbed onto or encapsulated within the rock

$\begin{array}{ll}\text { Figure 6: } & \text { BCR extraction procedure }\end{array}$

Figure 7: $\quad$ Standard Tessier sequential extraction procedure $\quad 16$

Figure 8: $\quad$ General sampling locations 20

Figure 9: $\quad$ MT 15 and MT 18 sediment and water sampling locations in the Mud river watershed

Figure 10: MT34B water and sediment sampling location in the spruce fork watershed

Figure 11: Sampling locations for background control samples

Figure 12: Ultrasound extraction experimental set up

Figure 13: Variation of temperature with sonication time for the larger probe $(1.905 \mathrm{~cm})$

Figure 14: Variation of temperature with sonication time for the smaller probe $(0.3 \mathrm{~cm})$

Figure 15: Release of total selenium (ng/g) as a function of sonication time

Figure 16: The release of total arsenic $(\mu \mathrm{g} / \mathrm{g})$ as a function of sonication Time

Figure 17: Variation of $\mathrm{pH}$ with sonication time 
Figure 18: Variation of Se (IV) and the disappearance of As (III) as a function of sonication time

Figure 19: The release of total Se and Se (IV) from BT571 as function of sonication time

Figure 20: The release of total Se and Se (IV) from BT700 as a function of sonication time

Figure 21: $\quad$ Particle size measurement flow process using SALD 3101

Figure 22: Sequential extraction for selenium

Figure 23: Selenium (IV) concentration released in batch sonicated extracts

Figure 24: Total selenium concentration released in batch sonicated extracts 67

Figure 25: Total arsenic released in batch sonicated extracts 68

Figure 26: Particle size distributions as function of sonication time 69

Figure 27: Variation of mean particle size with sonication time 70

Figure 28: $\quad$ Selenite $(\mathrm{ng} / \mathrm{g})$ extracted after 20 minutes of sonication 73

Figure 29: Total selenium extracted after 20 minutes of sonication $\quad 74$

Figure 30: Total arsenic $(\mu \mathrm{g} / \mathrm{g})$ sample extracted after 20 minutes of sonication

Figure 31: Sequential extraction of selenite in core samples 76

Figure 32: Sequential extraction of total selenium in core samples 77

Figure 33: Sequential extraction of total arsenic in core samples 78

Figure 34: Comparison of bioavailable selenite with ultrasound extraction $\quad 80$

Figure 35: Comparison of bioavailable and total arsenic with ultrasound extraction

Figure 36: Comparison of bioavailable total Selenite with ultrasound extraction 
Figure 37: Sequential extraction of selenite from sediments on a logarithmic scale (with averaged concentration results)

Figure 38: Sequential extraction of total selenium from sediments on a logarithmic scale

Figure 39: Sequential extraction of arsenic from sediments on a logarithmic scale

Figure 40: $\quad$ Sorption of selenite, selenate, arsenite and arsenate on kaolin as a function of $\mathrm{pH}$

Figure 41: Calibration curve for the determination of humic acid (HA)

Figure 42: $\quad$ Sorption of humic acid on kaolin

Figure 43: Optimization of the sorption kinetics of humic acid on kaolin

Figure 44: $\quad$ Reduction of $50 \mathrm{ng} / \mathrm{mL} \mathrm{Se}(\mathrm{VI})$ to Se (IV) at $\mathrm{pH} 7$

Figure 45: $\quad$ Reduction of $50 \mathrm{ng} / \mathrm{mL} \mathrm{Se}(\mathrm{VI})$ at $\mathrm{pH} 4$

Figure 46: The structure of kaolinite (with contributing charges on the silicon tetrahedral and the $\mathrm{Fe}^{+2} / \mathrm{Mg}^{+2}$ octahedral)

Figure 47: The structure of illite

Figure 48: The structure of montmorrillonite

Figure 49: The structure of vermiculite

Figure 50: The structure of chlorite

Figure 51: A scree plot showing all the PCs and their corresponding eigenvalues

Figure 52: A variable Loading plot for PC 1vs. PC 2

Figure 53: A two dimensional sample score plot (total PC variance $63.7 \%$ )

Figure 54: A biplot showing the relationship between objects (samples) and variable loadings

Figure 55: A three dimensional score plot (total PC variance 74.0\%)

Figure 56: Secondary PCA loading plot for mineral inclusions 
Figure 57: A two dimensional scatter plot between standardized values for $\mathrm{ng} / \mathrm{g}$ selenium and $14-\hat{\AA}$-d-spacing clay concentrations

Figure 58: A contour plot between total selenium, selenite and $14 \AA$ d spacing clay concentrations

Figure 59: A two dimensional scatter plot between standardized values for $\mathrm{ng} / \mathrm{g}$ selenium and $\%$ kaolinite

Figure 60: A two dimensional scatter plot between standardized values for $\mathrm{ng} / \mathrm{g}$ arsenic and $\%$ illite

Figure 61: A two dimensional scatter plot between standardized values for $\mathrm{ng} / \mathrm{g}$ arsenic and $\%$ plagioclase

Figure 62: A two dimensional scatter plot between standardized values for $\mathrm{ng} / \mathrm{g}$ arsenic and \% kaolinite

Figure 63: A diffractogram for an untreated clay sample

Figure 64: A scree plot for the secondary principal component analysis

Figure 65: A three dimensional plot of the secondary PCs

Figure 66: A biplot for the secondary PCA 


\section{List of Tables}

Table 1: $\quad$ Power parameters for $0.3 \mathrm{~cm}$ diameter probe in $10 \mathrm{ml}$ water $\quad 34$

Table 2: $\quad$ GFAAS program for selenium analysis 36

Table 3: $\quad$ GFAAS program for arsenic analysis 37

Table 4: $\quad$ Microwave acid digestion heating program 39

$\begin{array}{lll}\text { Table 5: } & \text { X-ray diffraction results } & 40\end{array}$

Table 6: X-ray fluorescence results $\quad 41$

Table 7: $\quad$ Comparison of extraction techniques 45

Table 8: $\quad$ Accelerated first order kinetic modeling for the extraction of total Se and total As $\quad 51$

Table 9: $\quad$ First order kinetic modeling for the release of Se (IV) 55

Table 10: X-ray fluorescence data for the samples 64

Table 11: X-ray diffraction data for the samples 65

Table 12: Comparison of selenium concentrations in water samples $\quad 88$

Table 13: Comparison of total and ultrasound extractable arsenic and selenium in sediments

Table 14. Concentration of arsenic and selenium in background water and sediment samples.

Table 15: Comparison of experimental and certified concentrations of arsenic and selenium in the USGS Green river shale reference material

$\begin{array}{lll}\text { Table 16: } & \text { Recoveries for arsenic and selenium } & 108\end{array}$

$\begin{array}{lll}\text { Table 17: } \quad \text { X- ray diffraction and microscopic results } & 121\end{array}$

Table 18: X-ray fluorescence and graphite furnace analysis data $\quad 122$

Table 19: Variable contribution to the first eight PCs and their respective eigenvalues 
Table 20 : Reflection lines for lithologic identification

Table 21: Secondary principal components and their respective eigenvalues 


\section{Chapter 1: Mountaintop Removal/Valley Fill Coal Mining and the Release of Selenium and Arsenic into Surface Water}

Mountaintop removal/valley fill (MTR/VF) coal mining is a process that involves the removal of mountain tops to expose beds of coal. As shown in Figures 1 and 2, MTR/VF begins with the removal of the flora and fauna necessary for the maintenance of ecological balance in the affected areas. After clearing trees, soil and waste rock are unearthed in search of coal beds. This rock material generated by the mining phase is placed in adjacent valleys and streams creating valley fills. Deposition of the rock material into the stream beds often covers and suffocates benthic organisms that are needed for the sustenance of the natural aquatic environments.

Hartman et al. ${ }^{1}$ found reduced densities of microinvertebrates in streams affected by MTR/VF mining which they proposed was due to the elevated conductivity caused by increased concentrations of ions ( $\mathrm{Na}, \mathrm{K}, \mathrm{Mn}, \mathrm{Mg}, \mathrm{Ca}, \mathrm{Ni}$ and $\mathrm{Fe}$ ) and fine sediment compared to reference streams. Valley fills have been found to leach a variety of metals that disturb the ecological balance in natural aquatic systems. ${ }^{2-4}$ MTR/VF is considered an attractive mining method by coal operators because it allows for an efficient exposure of coal beds while minimizing operational costs. They suggest that the resulting horizontal surfaces may be used for a variety of purposes that include building houses, shopping malls and recreational facilities.

The USEPA National Interim Primary Drinking Water Regulations maximum contaminant level (MCL) for selenium is $50 \mathrm{ng} / \mathrm{mL}$. A concentration higher than the MCL has the potential to cause the following effects from a lifetime exposure: hair and fingernail loss; damage to kidney and liver tissue, and the nervous and circulatory systems. ${ }^{5}$ The USEPA criterion continuous concentration (CCC) for selenium, which is 
an estimate of the highest concentration of selenium in surface water to which an aquatic community can be exposed indefinitely without resulting in an unacceptable effect, has been set as $5 \mathrm{ng} / \mathrm{mL}^{6}$ In a 2001 USEPA study undertaken in a MTR/VF mining area in southern West Virginia, measured selenium concentrations were higher than $5 \mathrm{ng} / \mathrm{mL}$ in 66 out of the 213 water samples collected. All 66 sampling locations were located downstream from filled sites. No detectable arsenic concentrations were found in all 213 water samples collected ${ }^{7}$. Individuals who drink water containing arsenic in excess of EPA's MCL of $10 \mathrm{ng} / \mathrm{mL}^{8}$ over many years could experience skin damage or problems with their circulatory system, and may have an increased risk of getting cancer. The EPA $\mathrm{CCC}$ for arsenic is $150 \mathrm{ng} / \mathrm{mL}$.

\section{Chemical speciation of arsenic and selenium}

Bioavailability and toxicity of arsenic and selenium depend not only on their total concentration but also on their physicochemical nature. Inorganic forms of both arsenic and selenium are generally considered to be more potent toxins compared to organic forms.

\section{Selenium speciation}

Selenium exists in -I, -II, 0, IV and VI oxidation states. Most organic forms are in the $-\mathrm{I}$ and -II oxidation states and are mainly found in biological systems and in reducing swampy environments. In biological systems selenosugars, selenoproteins and selenoamino acids have been reported. ${ }^{9}$ Biotransformation through alkylation of selenium is a detoxification process that changes the more poisonous inorganic selenium to alkylselenium species that are less toxic and are easily excreted through the urine and sweat in animals and also as volatile gases in plants. ${ }^{10}$ Volatile compounds such as 


\section{Original Profile}

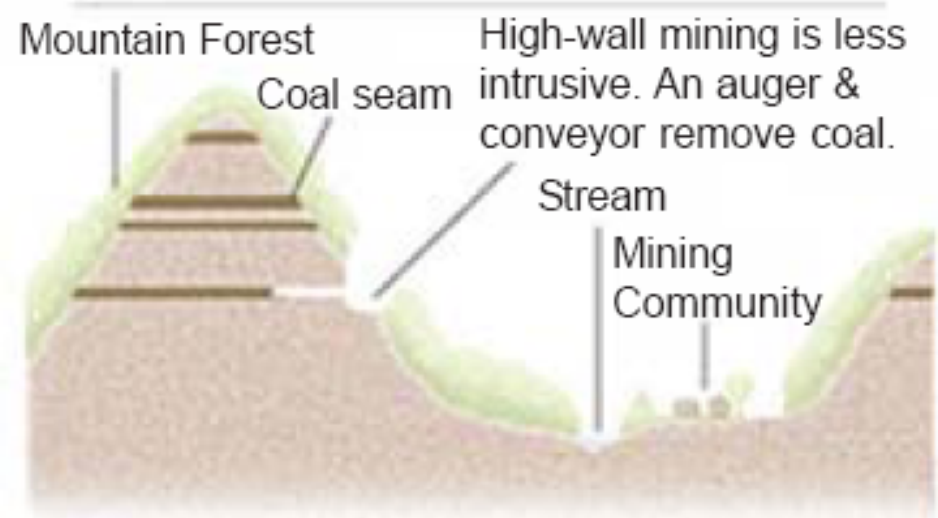

\section{Mountaintop removal}

Mining companies strip forests and topsoil, then blast the mountain apart layer by layer to get to coal seams.

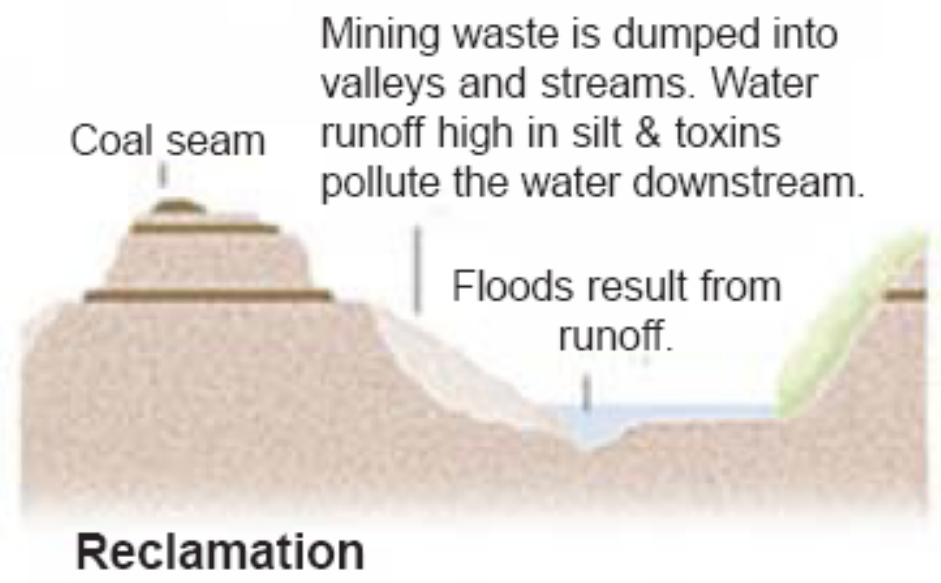

Mining waste is smoothed out and steep slopes are terraced. Even with chemical treatments \& fertilizers, forests \& vegetation at MTR sites have a hard time regrowing.

Mining spoil fills valley.

Figure 1: Step by step overview of mountaintop removal /valley fill procedure. ${ }^{11}$ 


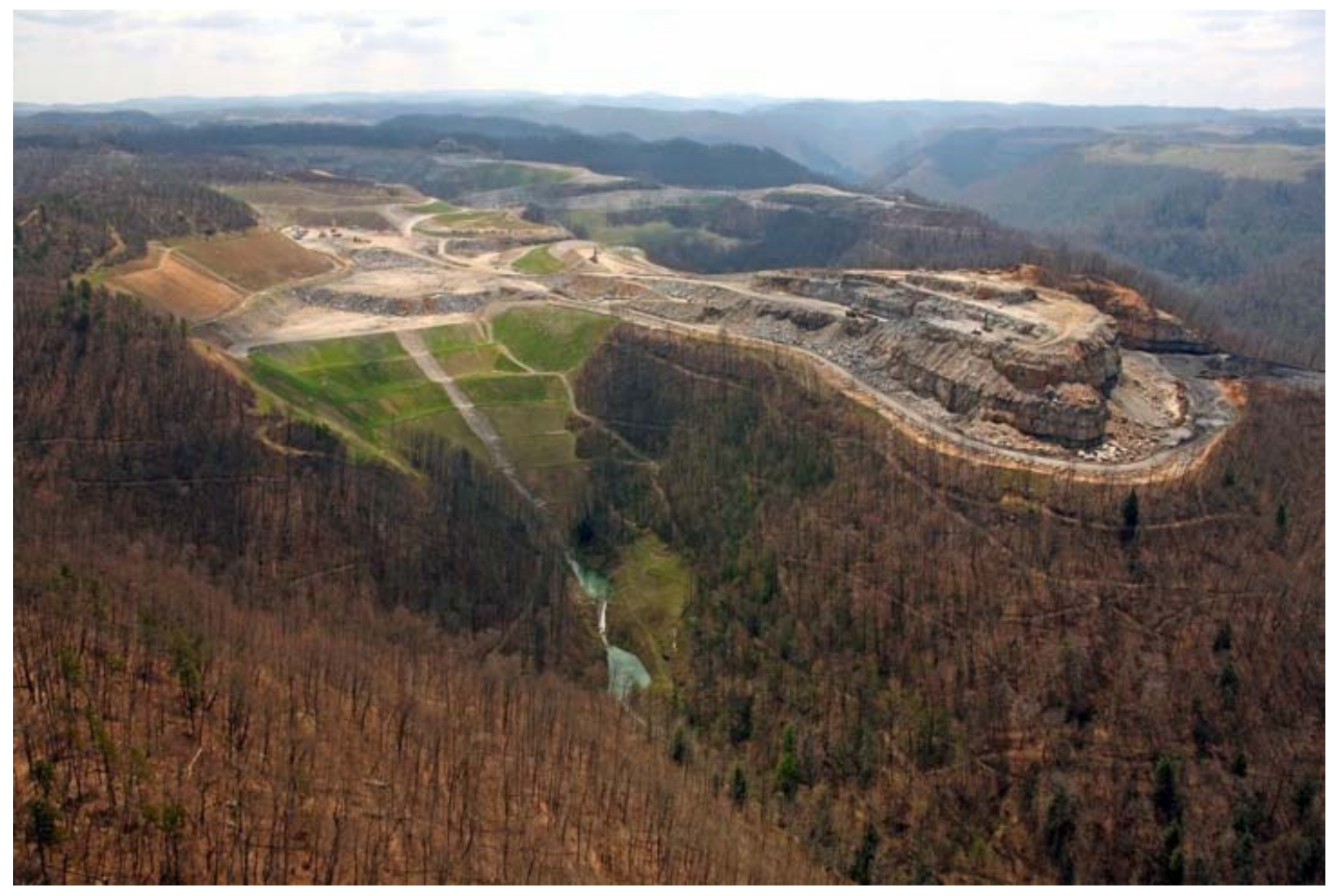

Figure 2: A view of the 1929-acre mountaintop removal site in Bob White, Boone County, W.Va. In the middle is a valley fill, which contains the mountains that made up Island Creek Mountain and buries the headwaters of Big Branch Creek. The mountain peak on the right has been clear-cut and decapitated; blasting blows away the rock to the coal seam, April 2007. ${ }^{12}$ 
dimethylselenide, dimethyldiselenide ${ }^{10,13}$ and hydrogen selenide are produced by some plants and microorganisms ${ }^{14}$ through the detoxification process. Humans excrete trimethylselenonium ion ${ }^{10}$ in urine.

Depending on the prevailing $\mathrm{pH}$ and redox potentials in natural waters, selenium is mainly found as selenite $\left(\mathrm{SeO}_{3}^{-2}\right)$ or selenate $\left(\mathrm{SeO}_{4}^{-2}\right)$. Selenite is less mobile in water compared to selenate and is mainly found in acidic waters with reducing redox potentials. Selenates are found in mainly high $\mathrm{pH}$ environments under oxic conditions as shown in Figure $3 .{ }^{15}$ Selenites are generally considered to be more toxic compared to selenates and are more easily bioaccumulated. ${ }^{16}$

\section{Arsenic speciation}

In natural waters arsenic is found mainly as arsenite $\left(\mathrm{AsO}_{3}^{-3}\right)$ or arsenate $\left(\mathrm{AsO}_{4}^{-3}\right)$. Arsenite is more mobile because it is neutral $\left(\mathrm{H}_{3} \mathrm{AsO}_{3}\right)$ at $\mathrm{pH} 5$ to 8 which is very common in water and sediments. ${ }^{15}$ Arsenite is mainly found in reducing environments whereas arsenate is mainly found under oxidizing conditions. In general arsenite is more toxic and reactive compared to arsenate ${ }^{17}$ Both arsenic and selenium are used as terminal electron acceptors during anaerobic respiration. ${ }^{18}$ The distribution of arsenic species in water is shown in Figure $4 .{ }^{19}$

\section{Selenium and arsenic toxicity to fish and other wildlife}

In 1980s fish and wildlife died at Kesterson National Wildlife Refuge in California due to selenium poisoning as a result of direct and indirect consumption of polluted agricultural drainage emanating from nearby farms. ${ }^{20,21}$ Selenium concentrations in bird livers were found to be in the range associated with adverse reproductive effects. Elevated selenium concentrations in fish and bird eggs are associated with higher 


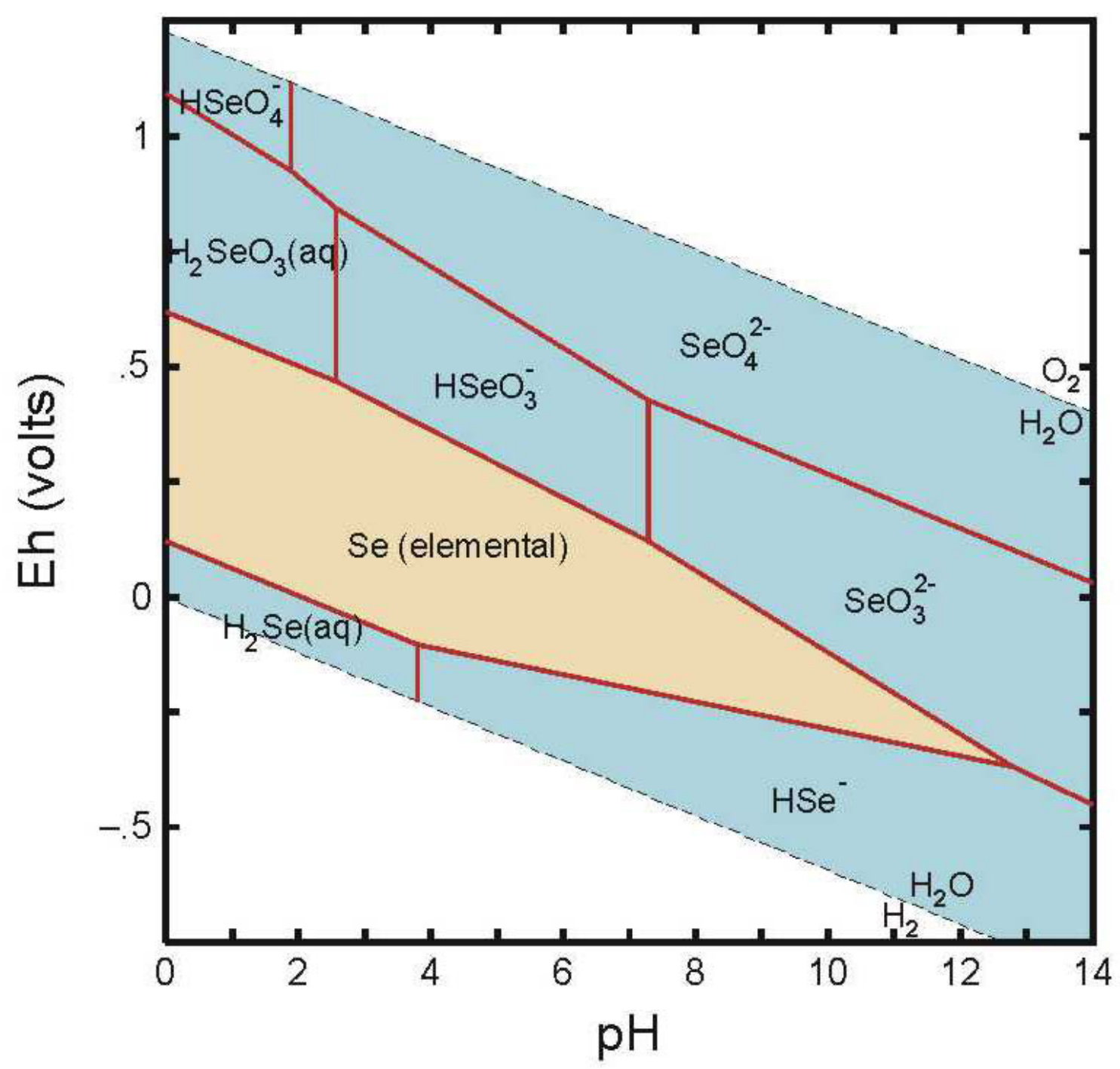

Figure 3: Eh-pH diagram for dissolved selenium species. ${ }^{15}$ 


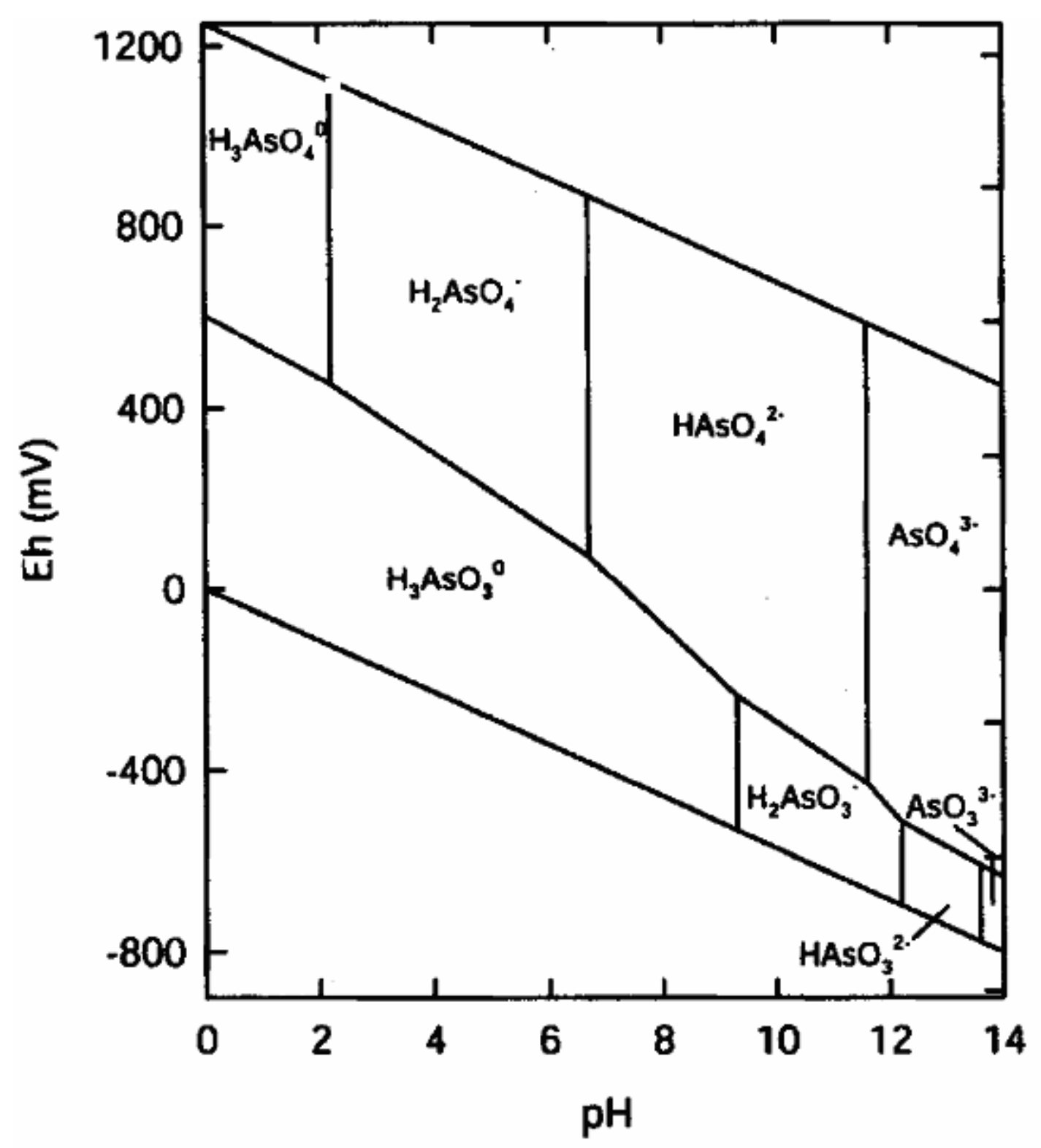

Figure 4: Eh-pH diagram for dissolved arsenic species. ${ }^{19}$ 
teratogen and mortality rates.

It is currently being debated whether to change the $5 \mathrm{ng} / \mathrm{ml}$ surface water (CCC) selenium standard to actual concentration of selenium in the flesh of fish as a result of bioaccumulation and biomagnification. A new fish standard has been suggested as 7.9 $\mu \mathrm{g} / \mathrm{g}$ fish, which was found to reduce approximately $80 \%$ of the chronic diseases in fish.

${ }^{22}$ However, this has raised some concern because adult fish may not show evidence of selenium intoxication. The primary point of concern has been identified to be the passage of selenium from adult female fish to eggs. Eggs that had concentrations above $10 \mu \mathrm{g} / \mathrm{g}$ were found to have deleterious biochemical malfunctions that led to teratogenic deformities and death. ${ }^{22}$ Further, metabolism of selenium varies in winter and in summer, and higher concentrations of selenium combined with low water temperatures $\left(4^{\circ} \mathrm{C}\right)$ were shown to result in reduced activity and feeding, depletion of $50-80 \%$ of body lipid, and significant mortality within 60 days. ${ }^{23}$ Fish in warm water only showed increased oxygen uptake and no harmful physiological and feeding variations were observed. ${ }^{23}$

All arsenic species have been discovered to have profound toxic and teratogenic effects on living organisms. The toxicity of arsenic in different types of fish has been widely studied and recently $1.02 \mu \mathrm{g} / \mathrm{ml}$ of arsenic was reported to kill $50 \%$ of Tilapia fish. $^{24}$

\section{Release of arsenic and selenium from waste rocks}

Common mathematical models used to describe the kinetics for the release of inorganic and organic substances from solids into solution are parabolic diffusion, elovich, power function and first and second order kinetic models. ${ }^{25-28}$ These models are often used to approximate the overall chemical kinetics of intricate reactions occurring 
in complex matrices that are often unknown.

First order kinetics are used to describe a desorption process that is controlled by surface film and intraparticle diffusion. ${ }^{29}$ The derivations of the first order kinetic model for a reversible desorption /sorption reaction is shown in Appendix 1A. The first order kinetic equation can be written as follows,

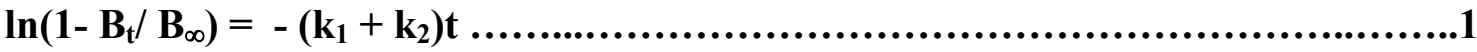

Where $\mathbf{B}_{\mathbf{t}}$ is the concentration of extracted/released species at time $\mathbf{t}$. $\mathbf{k}_{\mathbf{1}}$ and $\mathbf{k}_{\mathbf{2}}$ are the first order reaction constants for the forward (release) and backward (sorption) reactions and $\mathrm{B}_{\infty}$ is the concentration of released species at infinite release time.

With respect to the increasing concentration of the desorbed species B in the mixture, $\mathbf{k}_{\mathbf{1}}$ has a negative slope and $\mathbf{k}_{\mathbf{2}}$ has a positive slope. Equation $\mathbf{1}$ clearly shows that there are two competing rate constants that bring about change in the sorption/desorption kinetics. For desorption to occur, the condition $\mathbf{k}_{2}>>\mathbf{k}_{1}$ is imperative otherwise sorption will become dominant. Equation 1 can be simplified to

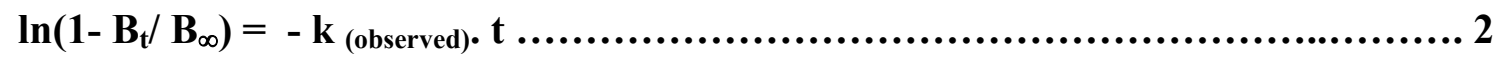

Where $\mathrm{k}_{\text {(observed) }}=\mathrm{k}_{1}+\mathrm{k}_{2}$.

\section{Approximation of $\mathbf{B}_{\infty}$}

$\mathbf{B}_{\infty}$ is approximated by plotting $\mathbf{B}_{\mathbf{t}}$ vs. $\mathbf{B}_{\mathbf{t}+\mathbf{x}}\left(\right.$ Kezdy-Swinebourne method $\left.{ }^{30}\right)$

where $\mathbf{x}$ is a constant temporal incremental factor used to pair up early data points with the later ones. The point at which this line intersects a $45^{\circ}$ line on the Cartesian plane is used to estimate the $\mathbf{B}_{\infty}$ value. An appropriate value of $\mathbf{x}$ has to be chosen. It is recommended that $\mathbf{x}$ should $2 \sim 3$ times the half-life of the total (approximated) concentration (Appendix 1B). A plot of $\ln \left(\mathbf{1}-\mathbf{B}_{\mathbf{t}} / \mathbf{B}_{\infty}\right)$ vs. $\mathbf{t}$ yields a slope equal to 
$\mathbf{k}_{\text {observed}}$.

\section{Environmental impacts of released selenium and arsenic}

Once released from valley fills, selenium and arsenic can enter many different pathways that are dependent on the physical and chemical properties of the water and sediment. The combined concentrations of (i) soluble amounts released immediately into the liquid phase and (ii) amounts retained by the solid phase that can be easily transferred into the liquid phase is bioavailable. ${ }^{31}$ The release rates from the solids depend on their relative bioavailabilities. Hence as illustrated in Figure 5, phases 2 - 4 represent the labile fractions that are bioavailable compared to the inert material in phase 1.

The fate of the released selenium and arsenic also depends on the environmental conditions that include $\mathrm{pH}$, electrochemical properties, presence or absence of complexing agents such as natural organic matter ( humic and fulvic acids) and other reactive organic and inorganic materials. ${ }^{32,33}$ Such environmental conditions can result in changes of oxidation states and the sequestration or remobilization of selenium and arsenic, thereby controlling their bioavailabilities and toxicities. It is generally accepted that self purification of river systems will result in coagulation and a greater proportion of pollutants will eventually get deposited and immobilized in riverbeds. ${ }^{34-36}$ In some situations the pollutant concentration in river water will decrease as a result of dilution as more water will be added downstream the source of the pollutant. Thus, river concentration can increase, decrease or remain at equilibrium depending on the rate of the introduction and residence time of the introduced pollutant. Elevated concentrations of these metalloids have also been shown to stunt the growth of some plants ${ }^{37,38}$ which could inhibit a critical process required in the remediation of filled sites. 


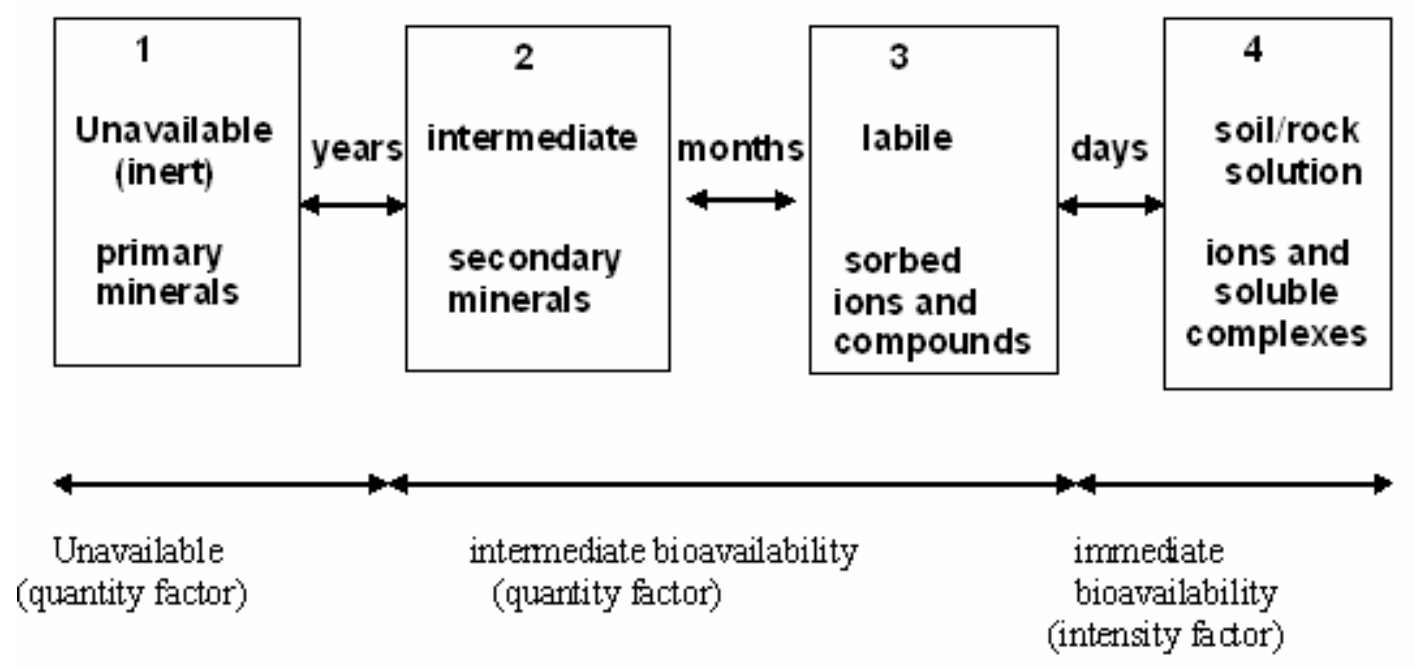

Figure 5: Bioavailability of species sorbed onto or encapsulated within the rock ${ }^{31}$. 
A variety of mathematical and theoretical simulations have been developed in an attempt to study the solid-solution chemistry in an effort to determine transport mechanisms upon introduction into the environment. ${ }^{39,40}$ Several authors have explored the adsorption and desorption techniques using a variety of pure adsorbents such as clays or goethite in the presence or absence of humic and fulvic substances. ${ }^{41-45}$ Desorption hysteresis studies provide insights into the remobilization of previously sorbed arsenic and selenium. The release of sorbed ions depends largely on their physicochemical nature and, to some extent on the solution properties of the extracting media. Su and Suarez ${ }^{46}$ indicated that selenate adsorption to iron oxide was reversible while selenite was not. The binding of selenate was shown to depend on ionic strength and that of selenite was not. Such information is especially important in determining the bioavailable fraction of selenium that originates from sediment under natural environmental conditions.

Manning and Goldberg ${ }^{47}$ studied the stability of the binding of arsenate and arsenite at the clay mineral-water interface and concluded that arsenite is more stable between $\mathrm{pH}$ values ranging from 4-9 and the arsenite is oxidized to arsenate above $\mathrm{pH} 9$. However, there was evidence of heterogeneous oxidation of arsenite on the clay surface that resulted in strongly bound arsenate. Most clay minerals and activated alumina have been shown to have more affinity towards arsenate than arsenite. Thus, even though arsenite species could be stable in water at natural water $\mathrm{pH}$ values that range from 6.58.5 , their concentrations were quickly diminished due to heterogeneous oxidation. They also concluded that modeling of arsenite oxidation on many common mineral matrices may not always be valid due to the uncontrollable catalytic oxidation processes that occur 
on the mineral surfaces. $\mathrm{MnO}_{2}$ impurities in clay minerals for example, have been shown to be responsible for the observed catalytic behavior in lake sediments. ${ }^{48}$

River sediment has been identified as an accumulator of both organic and inorganic pollutants and is an important indicator of environmental pollution. ${ }^{49,50}$ It is often the remobilization of the sorbed selenium and arsenic from the sediments that can lead to environmental consequences in river waters ${ }^{51}$, and the widespread incidences of

sediment contamination and its importance for ecosystem quality have been reported. ${ }^{52-54}$ A large number of sediment quality guidelines (SQGs) have been developed to aid regulators in dealing with contaminated sediments and Burton (2002) has reviewed their worldwide use. $^{55}$

\section{Extraction of selenium and arsenic from solid samples}

Bioavailable concentrations in sediments are usually obtained using standard and modified Tessier's extraction methods ${ }^{56}$ and total available by both open vessel and closed vessel acid digestion procedures. Traditionally, selenium and arsenic in solid samples have been extracted with water, $\mathrm{NaOH}$, phosphate buffers, oxidizing agents such as $\mathrm{K}_{2} \mathrm{~S}_{2} \mathrm{O}_{8}$, and a variety of concentrated acids with/without microwave digestions. ${ }^{57,58}$

Microwave digestions with strong acids result in complete dissolution of the solid samples. This results in the liberation into solution of both loosely and strongly bound metals together with residual metals that are closely associated with silicate matrices. Such extraction methods, although useful in estimating the entire amounts of available metals in solids, cannot give the essential information on the readily bioavailable concentrations that are immediately leached into aquatic systems soon after valleys are filled. 
It is imperative to use analytical methods that extract the loosely bound metals, which are readily mobile because their concentrations can quickly build up under conditions that favor high residence times. Acid Leaching, Standard Tessier, and the Standards, Measurements and Testing program (SMT) formerly known as BCR (Community Bureau of Reference, Commission of the European communities) methods are very useful in estimating the amount of metals available in different phases. ${ }^{59,60}$ The flow diagrams for the BCR and Standard Tessier extraction methods are shown in Figures 6 and 7, respectively.

The initial stage of the BCR method uses a weak acid (acetic acid) and in Standard Tessier extraction methods a highly concentrated chloride salt $(\mathrm{NaCl}, \mathrm{KCl}$ or $\mathrm{MgCl}_{2}$ ) is used to estimate both water soluble and exchangeable metals in solid samples. In the Acid Leaching method, $0.01-4 \mathrm{M} \mathrm{HCl}^{61}$ is used to represent an $\mathrm{HCl}$ extractable fraction which is often related to total concentration of selenium that can be released over an infinite period of time. Caution must be exercised when using acids in acidic-based digestions. Although these $\mathrm{HCl}$ extractions have been widely used for positively charged metallic species, their applicability to the extractions of selenium and arsenic oxoanions is questionable because these anions are closely associated with both humic (HA) and fulvic acids (FA) ${ }^{62}$ Humic acid is soluble in alkaline media and insoluble in acidic media whereas FA is soluble in both acidic and alkaline media. It is well-known that the toxicity and the bioavailability of any chemical species depend on both the total concentration and, often more importantly, on the chemical form. The use of acidic media, oxidizing, and reducing agents will often change the oxidation state of metals making the methods only good for the quantitation of species stable in that particular medium. 


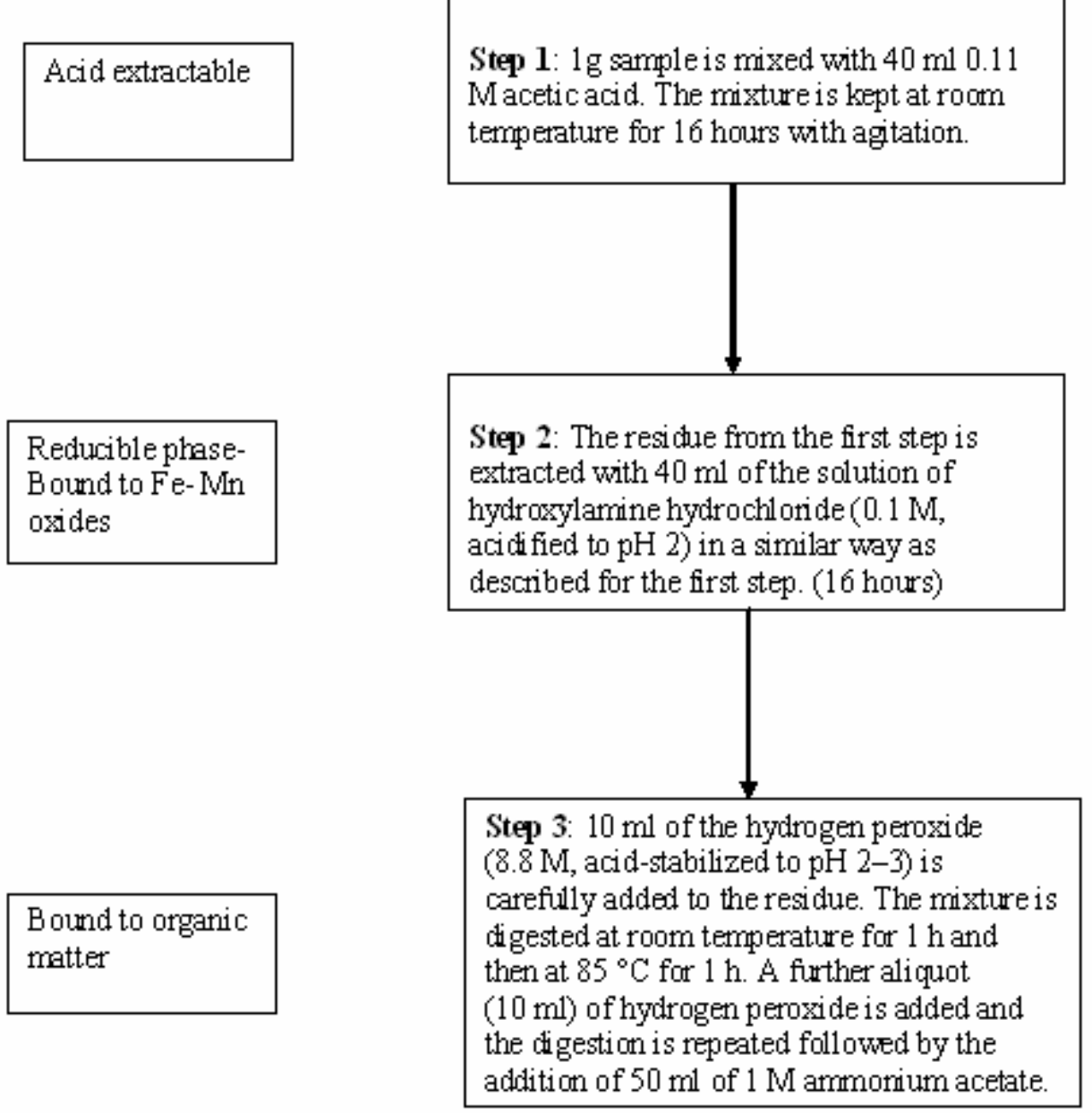

Figure 6: BCR extraction procedure. ${ }^{59}$ 


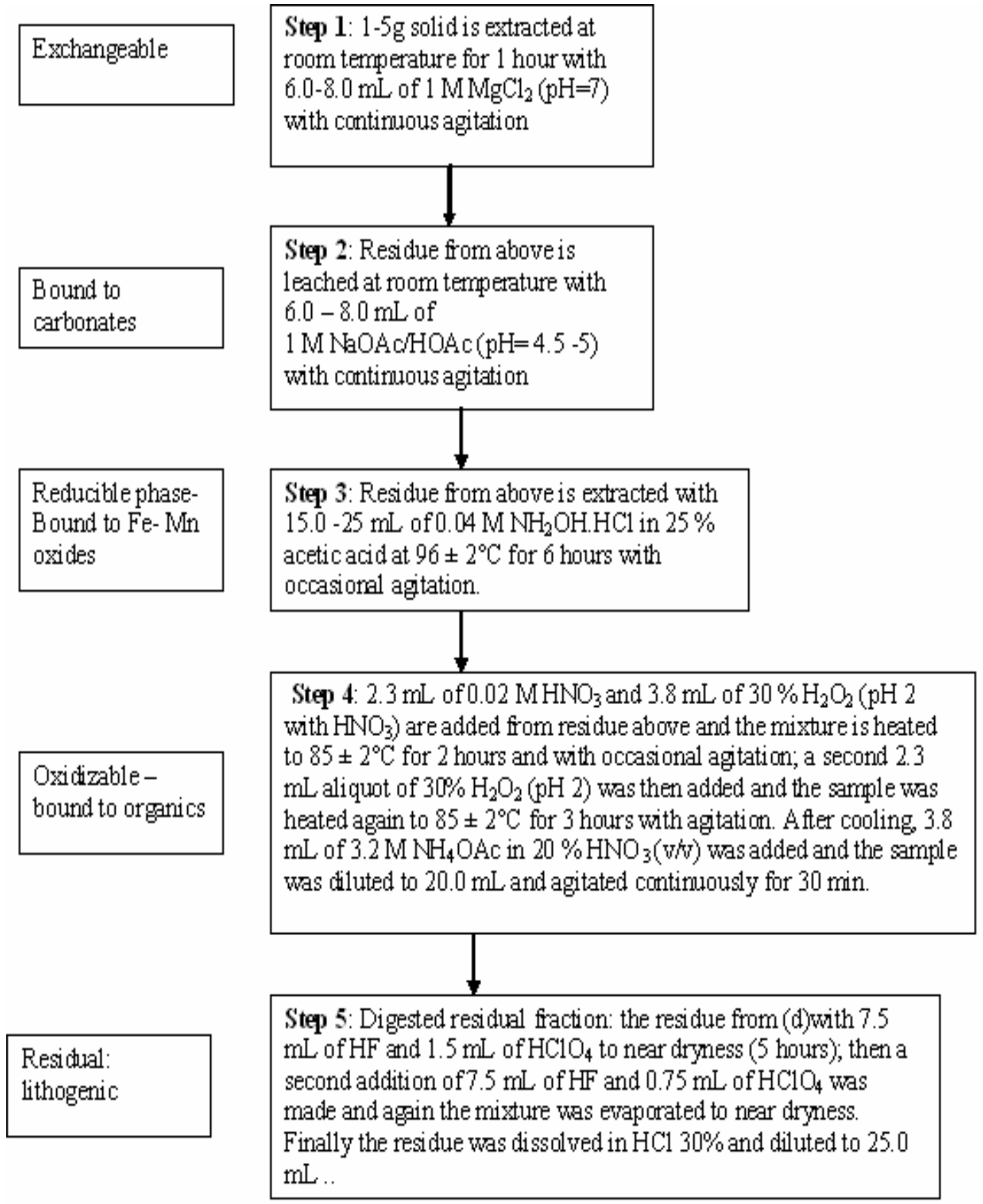

Figure 7: Standard Tessier sequential extraction procedure. ${ }^{63}$ 
This explains why there is a general consensus that deionized water should be used as an extracting solvent either hot or cold because it has the ability to preserve the natural oxidation state of metals being leached. ${ }^{64-67}$

Attempts have been made to use alkaline phosphate buffers and sodium hydroxide solutions to leach out and to preserve the oxidation states of selenium species. ${ }^{67}$

Phosphate buffer extractions have been found to remove both exchangeable and strongly bound selenium is soils with insignificant modifications of the oxidation states. The loosely bound portion that comprises the water-soluble and exchangeable fractions are the most bioavailable. The high chloride concentrations used in $\mathrm{BCR}$ and $\mathrm{HCl}$ based leaching protocols, although very essential in displacing the oxoanions from the solid surfaces by ion exchange, can also reduce Se (VI) to Se (IV) ${ }^{68}$ during the course of extraction thus altering the natural distributions of species in the samples important in assessing the immediate release and bioavailability of metals in the aquatic environment.

\section{Ultrasound extraction}

Ultrasound extraction can release metals from the solid into the liquid phase on a much shorter time scale thereby decreasing analysis times. ${ }^{69-74}$ Ultrasonic extraction enhances the dissolution process by producing acoustic cavitations that result in bubble formation and subsequent collapse generating high-pressure gradients, thereby increasing reactivities. ${ }^{75,76}$ The use of ultrasonic energy has proven to be an easy, convenient, and. fast way of desorbing inorganic ${ }^{58,73,77}$ and organic pollutants ${ }^{78}$ from sediments, soil and biological samples. ${ }^{79,80}$ Ultrasound extraction is also an aseptic method and it has been suggested that high frequency ultrasound $(20 \mathrm{kHz})$ in low volumes $(200 \mathrm{~mL})$ of bacterial suspensions resulted in a continuous reduction of bacterial cell numbers. ${ }^{81,82}$ Hence 
microbial sample alteration or modification after ultrasonic extraction is considered to be minimal if samples are placed in containers previously washed with ethanol.

In order to assess the contribution of the overburden from MTR/VF to the accumulation of arsenic and selenium in the streams and sediments, core samples, stream water, and sediments were collected from the affected areas in southern West Virginia and analysed for selenium and arsenic.

\section{Sample collection}

\section{Rock samples}

Rock samples were collected from a core obtained by the West Virginia Geological and Economic Survey (WVGES) from Kayford Mountain which is situated at the intersection of Boone and Kanawha Counties, West Virginia, USA $\left(81^{\circ} 21^{\prime} 31^{\prime \prime} \mathrm{W}\right.$, $\left.37^{\circ} 58^{\prime} 42^{\prime \prime}\right)$. The core was obtained by drilling from the mountaintop down to $270 \mathrm{~m}$ below the surface.

\section{Sediments and water samples}

Three water and three sediments samples were labeled as MT 15, MT 18 and MT 34 B by the WVGES in 2007 and were collected from the Mud River and Spruce Fork watersheds. All samples were placed in acid-washed polyethylene bottles and the sediments were freeze dried to preserve the natural oxidation states and then subjected to sequential and ultrasound extractions. Samples MT 15 and MT 18 were collected from the Mud River watershed and MT34 B was collected from the Spruce Fork watershed as shown in Figures 8-10.

MT 15 was collected approximately 700 feet upstream from the confluence with the Mud River. The site is located downstream of six valley fills. No mining activities 
were going on at the time of sampling and the last mining permit was issued in 1995.

MT 18 is downstream from two valley fills and the last mining permit was also issued in 1995. There were no mining activities going on at the time of sampling and the site is located approximately $2000 \mathrm{ft}$ upstream from the confluence with the Mud River. MT34 B sampling point is downstream from one valley fill and there was active mining going on at the time of sampling. The sampling point is approximately $900 \mathrm{ft}$ upstream from the confluence with Beech Creek and a downstream pond. In the 2000 study selenium concentrations were found to be $12.1 \mu \mathrm{g} / \mathrm{L}$ at MT $15,36.8 \mu \mathrm{g} / \mathrm{L}$ at MT18 and $22.7 \mu \mathrm{g} / \mathrm{L}$ MT $34 \mathrm{~B}$, respectively.

\section{Control samples}

Background sediment and water samples were collected from six pristine areas within Big Creek quadrangle, Jefferson County in southern West Virginia $\left(82^{\circ} 07^{\prime} 30^{\prime \prime} \mathrm{E}\right.$ $\left.82^{\circ} 00^{\prime}\right)$. These areas were not affected by MTR/VF activities. The sampling locations were labeled 1 to 6 as shown in Figure 11. Samples were taken from Sandlick Hollow (1), Schoolhouse Hollow (2), Slab Creek (3), Chestnut Creek (4), Doss Fork (5) and Charley Trace (6). Samples were collected in May 2008 by WVGES. 


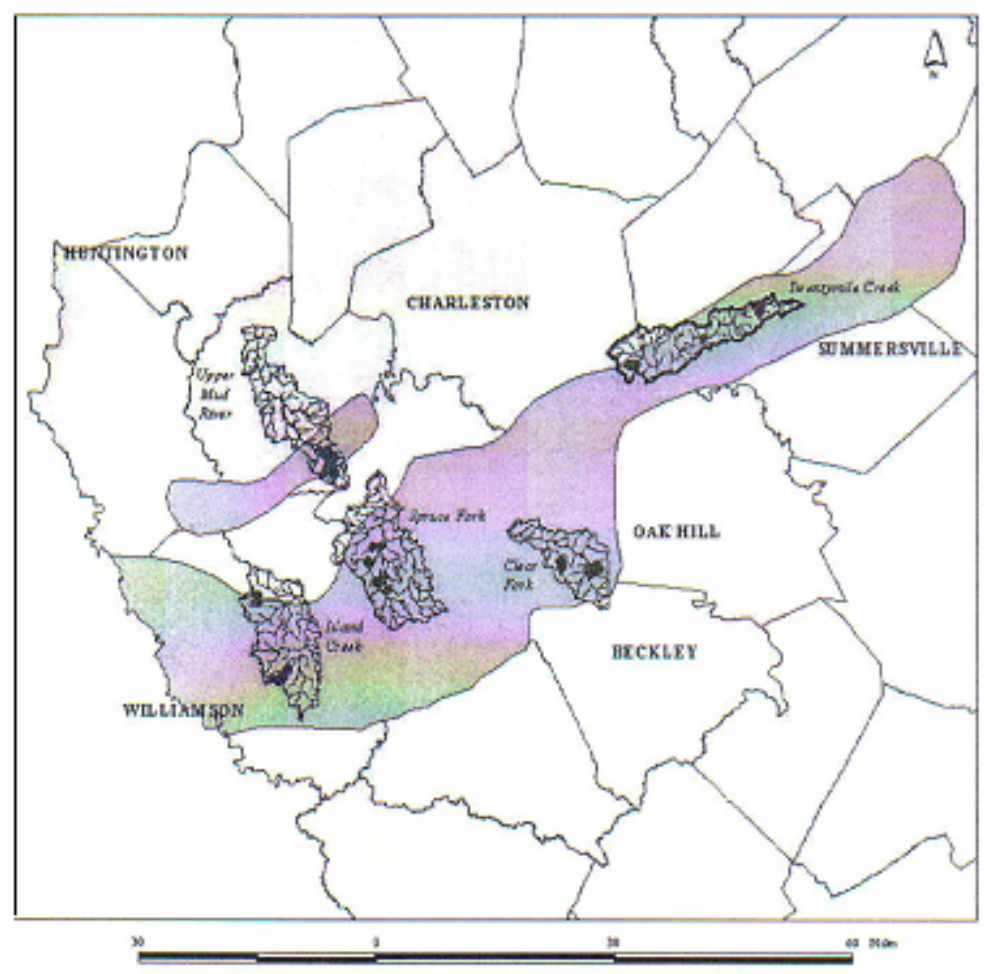

Figure 8: General sampling locations

Courtesy, West Virginia Geological and Economic Survey ${ }^{7}$ 


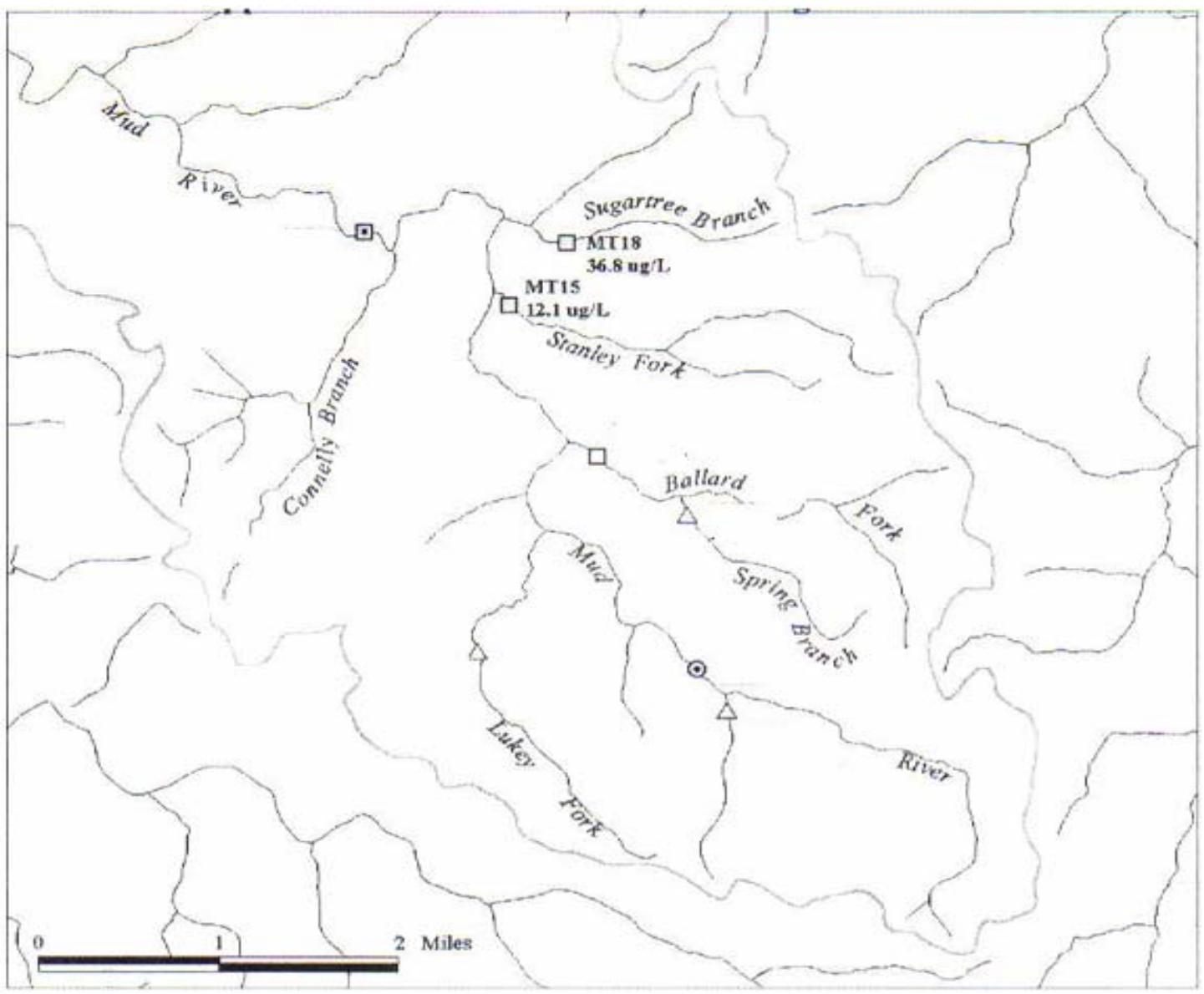

Figure 9: MT 15 and MT 18 sediment and water sampling locations in the Mud river watershed.

Courtesy, West Virginia Geological and Economic Survey ${ }^{7}$ 


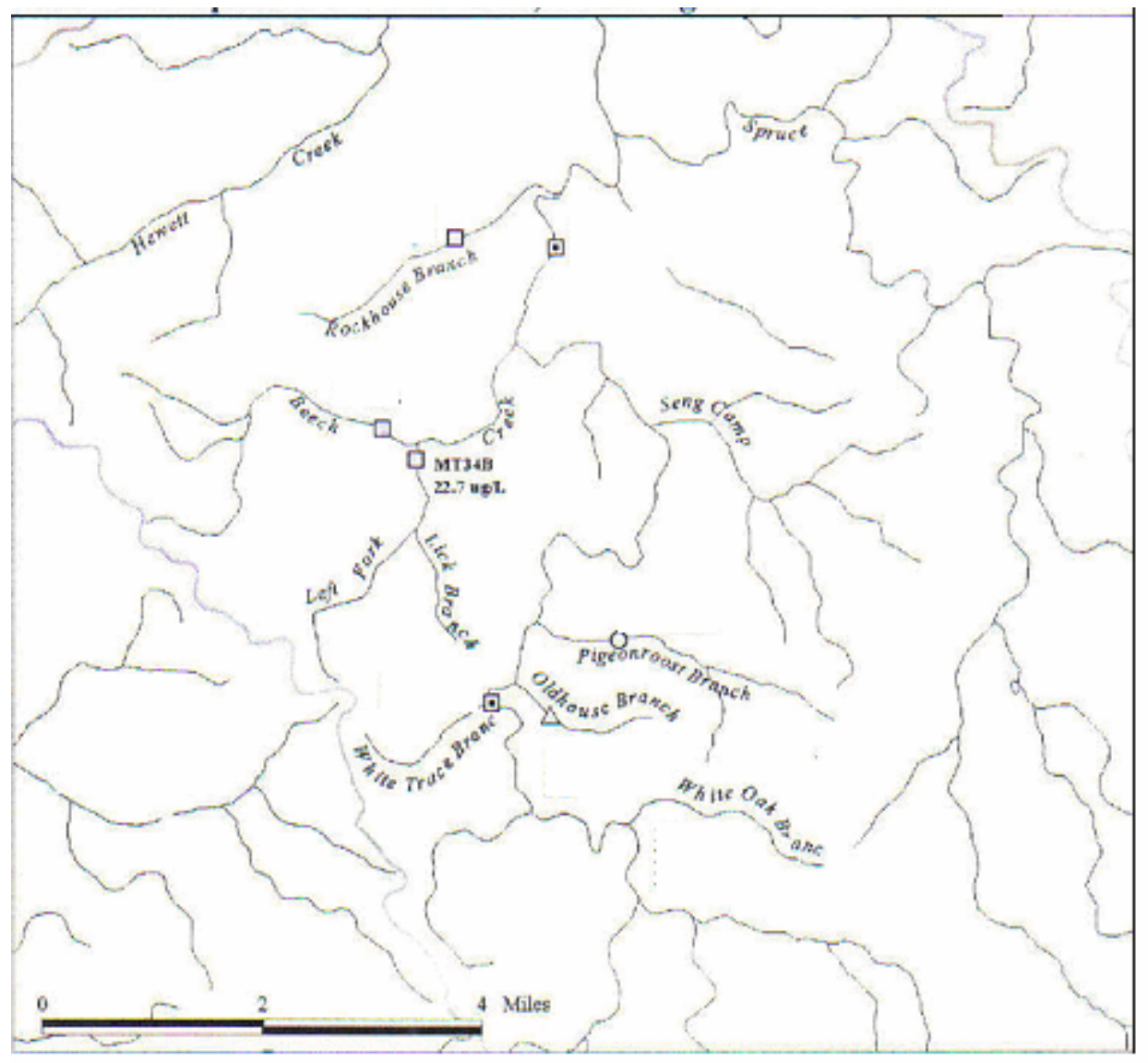

Figure 10: MT34B water and sediment sampling location in the spruce fork watershed.

Courtesy, West Virginia Geological and Economic Survey ${ }^{7}$ 


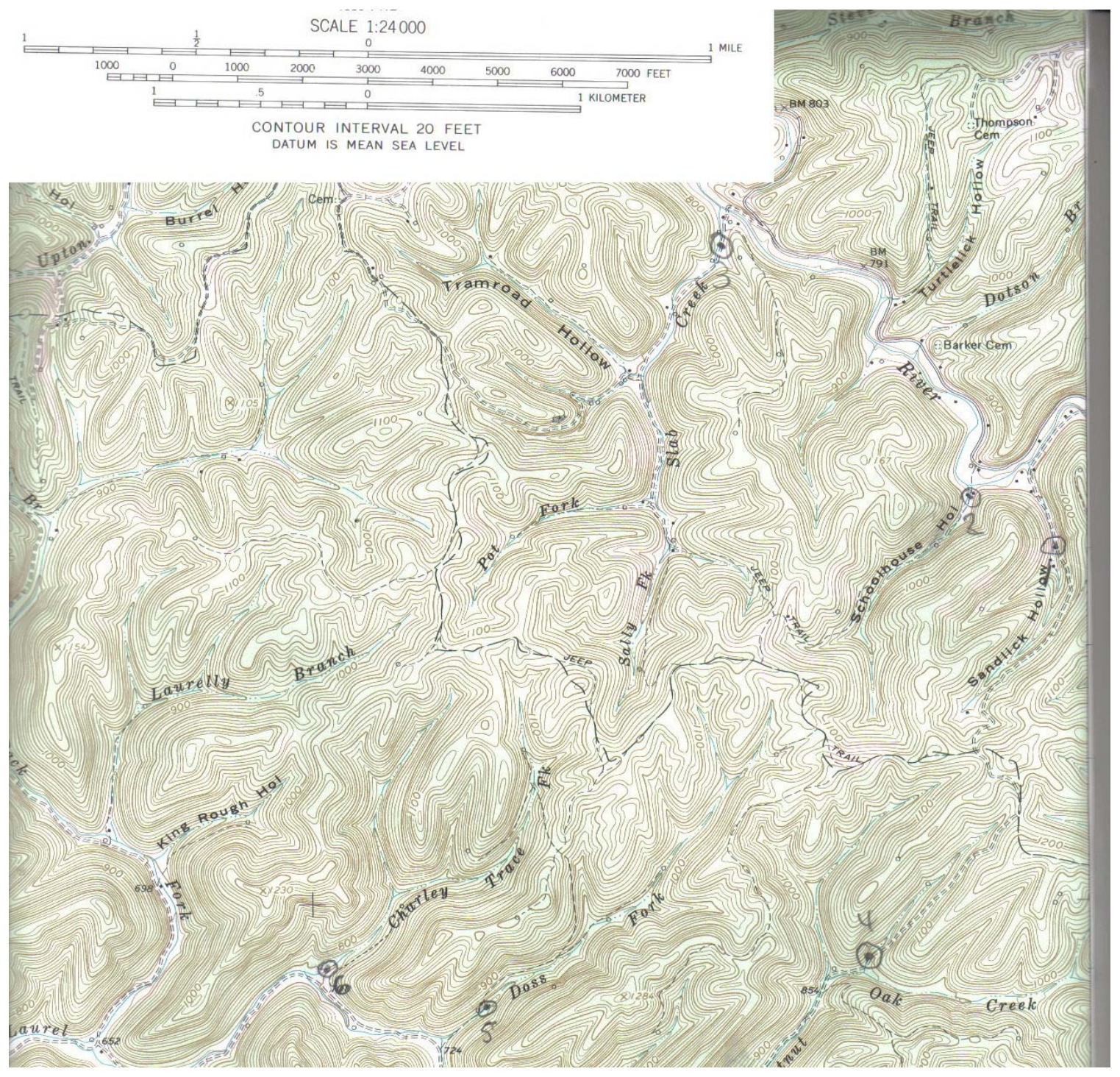

Figure 11: Sampling locations for background control samples

Courtesy, West Virginia Geological and Economic Survey ${ }^{7}$ 


\section{Chapter 2: Accelerated Aqueous Leaching of Selenium and Arsenic with Selenium Speciation Using Ultrasound Extraction}

\section{Introduction}

Temperature-controlled ultrasound extractions provide important kinetic data that can be useful in describing the chemistry at the solid-solution interface. Focused ultrasonic probes enable efficient adjustment and monitoring of temperature in a waterjacketed extraction vessel. The solid -solution chemistry can then be used to infer the bioavailabilities of metals released into associated aquatic systems. Most traditional batch extraction methods utilize lengthy mechanical shaking or soxhlet extractions that may take hours or days for a single extraction to be performed.

This methodology was used to investigate the kinetic release of arsenic and selenium from pulverized samples of rocks associated with coal mining activities. Since natural rock dissolution is a lengthy process ${ }^{83}$, ultrasound extraction was used to mimic the natural weathering of coal-associated rocks on a much shorter time scale. Comparative ultrasound-assisted kinetics of selenium and arsenic leaching from pulverized samples of rock associated with coal mining activities has been examined. Although the first order and parabolic diffusion models are both very important in describing the surface film diffusion or intraparticle diffusion of materials from rocks into solution ${ }^{83}$, the first order kinetic model was found to be most useful in comparing the rates of accelerated rock disintegration and the concomitant release of arsenic and selenium from coal-associated rocks. 


\section{Ultrasonic first order kinetics}

The diffusivity or velocity of the extracted species is proportional to the driving force acting on the species as they move out of the particles into the solution. It is being proposed that this ultimate velocity in sonochemical extractions is proportional to three factors namely the inherent mobility, $\mathbf{u}$ (which depends on solution $\mathrm{pH}$, surface area and lithology of rocks), sonication power $\mathbf{B}$ and the chemical potential, $\mu$ ( which is dependent upon the Gibbs function, $\Delta \mathrm{G}_{\mathrm{r}}$ between the adsorbed and the desorbed species).

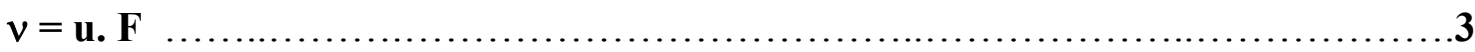

Where $v$ is the velocity in $\mathbf{c m ~ s}^{-1}, \mathbf{u}$ is the mobility of the extracted species in $\mathbf{c m s}^{-1} / \mathbf{N}$ $\mathbf{m o l}^{-1}$ and $\mathbf{F}$ the extraction force in newtons $(\mathrm{N})$ or applied potential.

Heterogeneous or homogenous extractions are governed by the ability of a chemical to move from one phase into another down a concentration gradient until equilibration or when the chemical potentials $(\mu)$ of the extracted species in the interacting phases are equal. ${ }^{84,85}$ The extraction force $\mathbf{F}$ can therefore be defined as $\mathbf{F}=\mathbf{d} \mu / \mathbf{d x}$

Where $\mathbf{d} \mu / \mathbf{d x}$ is a chemical potential gradient across a film of desorbing species. In sonochemical extractions, the extracting force $\mathbf{F}$ is magnified by the ultrasound power B as follows

$\mathbf{F}=\mathbf{B} \mathbf{d} \mu / \mathbf{d x}$

Hence combining 3, 4 and 5

$v=\mathbf{u} . \mathbf{B} \mathbf{d} \mu / \mathbf{d x}$ . .6 
Therefore, ultrasound assisted extraction rate constant is proportional to the following parameters: 1) $\mathrm{pH}, 2$ ) the mobility of the selenium and arsenic compounds from the solid to liquid phase, 3) the chemical potential of these species, 4) lithology of rocks extracted, 5) the surface area of particles, and 6) the level of ultrasonication.

\section{Samples}

Three samples were obtained from the WVGES from depths of 18 meters (BT60), 174 meters (BT571) and 214 meters (BT700), respectively. Each core sample had been subdivided lengthwise, pulverized and passed through a 60 mesh sieve. These sieved rock powders were then subjected to ultrasonic extraction.

\section{Experimental}

\section{Materials and methods}

An Ultrasonic Sonicator (Misonix, Model XL 2020) equipped with a $0.3 \mathrm{~mm}$ diameter titanium probe was used to deliver sound energy $\left(200 \mathrm{~W} / \mathrm{cm}^{2}\right)$ to a mixture of $1 \mathrm{~g}$ of pulverized sample and $10 \mathrm{~mL}$ water. A five-minute application of ultrasound energy to a pulverized rock sample mixture in a 1:10 solid to solution ratio was found to produce useful results for a single extraction. A 38-ml capacity water-jacketed extraction vessel (22mm ID x $10 \mathrm{~cm}$ quartz tube) was designed. The ultrasonic power was measured by calorimetry. ${ }^{86,87} \mathrm{~A}$ thermocouple was immersed into the extraction solution to monitor the temperatures during extraction and ultrasound energy measurement processes. The water/pulverized rock mixture was ultrasonicated for a period of five minutes followed by centrifugation for 20 minutes at $3400 \mathrm{~g}$. The supernatant solution was decanted and placed in a $25-\mathrm{mL}$ polyethylene vial. The solid residue was returned back to the sonication vessel followed by the addition of a fresh $10-\mathrm{mL}$ aliquot of water 
for the second ultrasonication step. The process was repeated seventeen additional times for a total 90 minutes of sequential extraction. Each extract was analyzed for total selenium and arsenic by graphite furnace atomic absorption spectrophotometry and Se (IV) and As (III) were measured by hydride generation atomic spectrophotometry. A Varian atomic absorption spectrometer (Model 55B) with $\mathrm{D}_{2}$ background correction was used to analyze all the samples. A larger titanium probe $(1.905 \mathrm{~cm}$ in diameter) was also used in the experiments together with a $308-\mathrm{mL}$ capacity sonication cell filled with 150 $\mathrm{ml}$ of nanopure water.

Approximation of total available arsenic and selenium in pulverized rock samples was performed through microwave digestion using a CEM Corporation MARS-5Explorer (Model 194A04CEM) and a combination of $\mathrm{HF}, \mathrm{HNO}_{3}$ and $\mathrm{HCl}$.

\section{Calorimetric power measurements}

The sonicator has a generator that produces $20 \mathrm{kHz}$ of electrical energy which is sent to a converter where electrical energy is transformed into mechanical vibrations. The converter has a $\mathrm{Pb}-\mathrm{Zr}$-Ti electroresitive piezocrystal that vibrates when subjected to $\mathrm{AC}$ voltages. The resistive piezoelectric crystal vibrates by expanding and contracting when responding to the opposite cycles of the $\mathrm{AC}$ current. The produced vibrations bring about sound energy at the horn tip (probe) that is passed on to the solution. The effective ultrasound energy dissipated into the solution does not always correlate to the power as defined by the manufacturer settings. It is therefore erroneous to report the effective power output using the manufacturer maximum power ratings because the magnitude of the power delivered is influenced by several factors that include type of sonication cell, positioning of the titanium probe tip, liquid height, the specific heat capacity and the 
density of the solvent used. ${ }^{87}$ The calorimetric power calculations were carried out using the following relationship

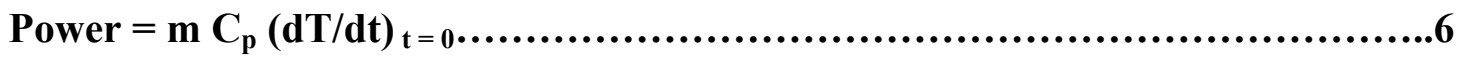

Where Power is in watts, $\mathbf{m}$ is the mass of the solvent, $(\mathbf{d T} / \mathbf{d t})_{\mathbf{t}=\mathbf{0}}$ is the initial slope of the curve temperature versus time at zero seconds. ${ }^{86-88}$

This slope $(\mathbf{d T} / \mathbf{d t})_{\mathbf{t}=\mathbf{0}}$ was approximated from the differentiation of a third order polynomial.

\section{Power measurement for $1.905 \mathrm{~cm}$ diameter probe tip}

Nanopure water $(150 \mathrm{~mL})$ was placed in a $308-\mathrm{mL}$ capacity cell and a probe $(1.905 \mathrm{~cm})$ was used in the application of ultrasound energy to the water. The maximum vibrational frequency setting number of 10 and $40 \%$ power output were employed in the experiments because the generator was unstable at power output greater that $40 \%$. The water inside the sonication vessel was initially equilibrated for 10 minutes at $24 \pm 1{ }^{\circ} \mathrm{C}$ and then continuously irradiated with sound energy for 110 seconds. The temperature (T) at 10 -second time $(\mathrm{t})$ intervals was recorded during the continuous sonication process for up to 110 seconds. This was repeated four times. The refrigerated water flowing in the jacket was maintained $24 \pm 1{ }^{\circ} \mathrm{C}$.

The value of $(\mathbf{d T} / \mathbf{d t})_{\mathbf{t}=\mathbf{0}}$ as obtained from the differentiation of the polynomial in Figure 13, $\mathrm{T}=7 \mathrm{E}-06 \mathrm{t}^{3}-0.0017 \mathrm{t}^{2}+0.2108 \mathrm{t}+23.692$ was 0.2108 . The third order polynomial was found to be the best fit as indicated by the $\mathrm{R}^{2}$ value $(0.9983)$. Hence the power dissipated by the generator into the $150 \mathrm{ml}$ nanopure water is given by

$150 \mathrm{~g} \mathrm{X} \mathrm{0.2108}{ }^{\circ} \mathrm{C} / \mathrm{s} \times 4.184 \mathrm{~J} /{ }^{\circ} \mathrm{C} . \mathrm{g}=132.3 \mathrm{~W}$. 

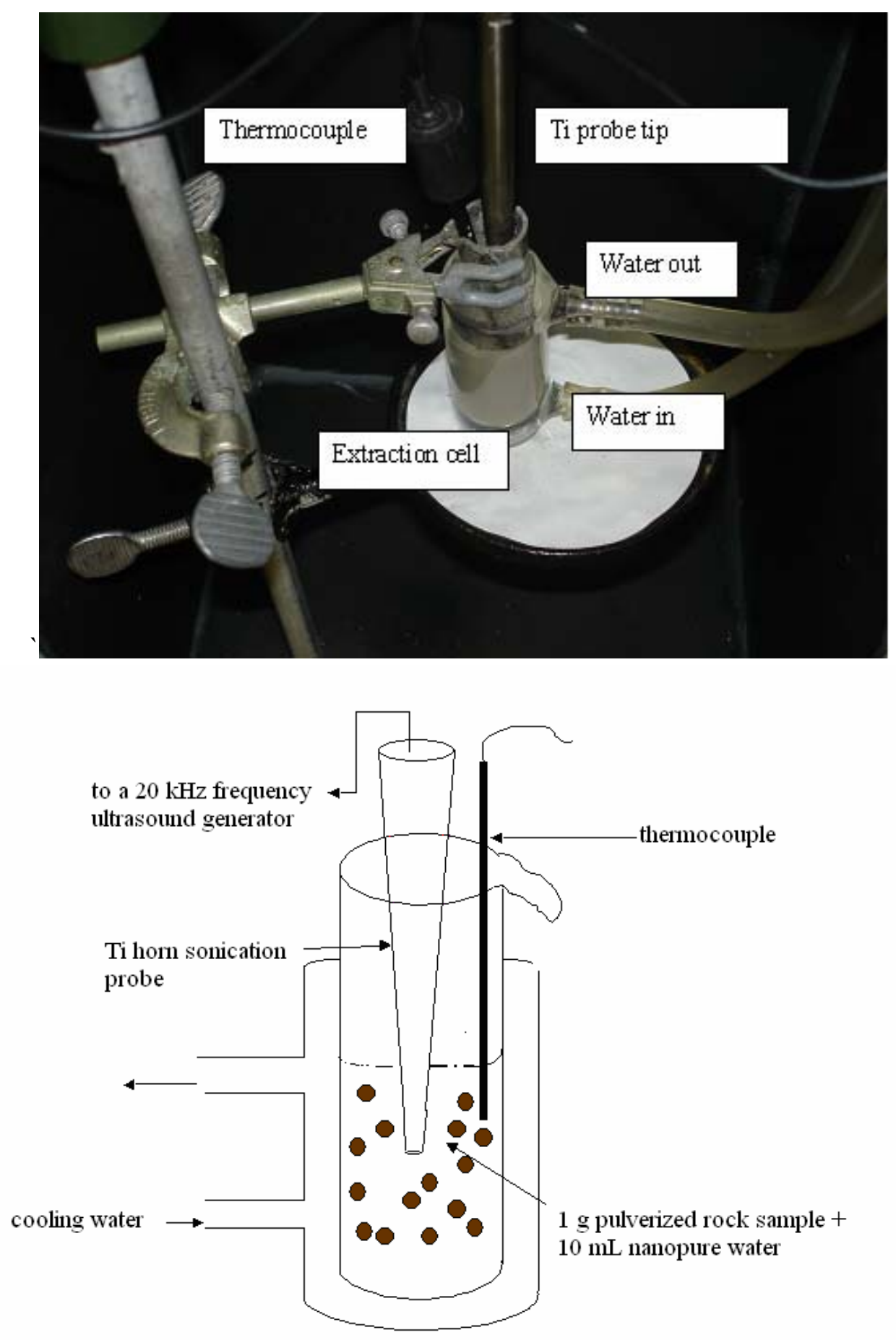

Figure 12: Ultrasound extraction experimental set up. 
The corresponding power intensity at the tip of the probe would be $46.4 \mathrm{~W} / \mathrm{cm}^{2}$. The power per unit volume is $0.882 \mathrm{~W} / \mathrm{mL}$.

\section{Power calculation for a $0.3 \mathrm{~cm}$ diameter probe tip}

A $0.3 \mathrm{~cm}$ diameter probe tip was used together with $10 \mathrm{ml}$ of nanopure water in a smaller sonication cell $(38 \mathrm{~mL})$. Experiments were performed in a manner previously described and the results obtained are given in Figure 14 and the summary in Table 1. Three power settings 2, 3 and 4 were explored because no meaningful vibrations were noticed at setting number 1 . The ultrasound generator was very unstable at vibrational settings 5 to 10 and therefore these vibrational settings were not used in the experiment. The power output was maintained at $40 \%$.

\section{Selection of an appropriate probe tip}

The larger tip delivered the highest amount of power $(132.3 \mathrm{~W})$ into the pulverized rock mixture compared to $14.15 \mathrm{~W}$ produced by the smaller tip. The $0.3 \mathrm{~cm}$ diameter probe at power setting number 4 was used to study the kinetics of ultrasoundassisted extraction because it produced higher power intensity, higher power per unit volume and was better suited for a smaller amount of sample $(1.0 \mathrm{~g})$ instead of $20 \mathrm{~g}$ that would have been required if the $1.905 \mathrm{~cm}$ diameter probe were used. The power almost doubled from one setting to another within the 2-4 range as indicated in Table 1.

\section{Reagents}

Arsenic and selenium stock solution (1000 ppm) were prepared from sodium selenite, (99.999\%, Aldrich), sodium selenate, (99\% Alfa Products), sodium arsenite, (99\% GFS chemicals) and sodium arsenate, (98\% GFS chemicals) 
Working standards were prepared by serial dilution of the $1000 \mathrm{ppm}$ stock solutions. The reagents for hydride generation AAS were $0.6 \% \mathrm{NaBH}_{4}$ (Fisher scientific) in $0.5 \%$ $\mathrm{NaOH}$ solution and 6M HCl(Fisher Scientific).

Microwave digestions were performed using $70 \% \mathrm{HNO}_{3}$ (Trace metal grade), 48 $\% \mathrm{HF}$ (Fisher scientific), $37 \% \mathrm{HCl}$ (Fisher scientific) and Boric acid crystals (Fisher scientific)

Varian partition graphite tubes (carbon coated), $5 \%$ and $500 \mathrm{mg} / \mathrm{L}$ $\mathrm{Ni}\left(\mathrm{NO}_{3}\right)_{2} .5 \mathrm{H}_{2} \mathrm{O}$ (Mallinckrodt) matrix modifiers for total selenium and arsenic analysis, respectively.

\section{Procedure for hydride generation AAS}

The sonicated extracts were aspirated into the reduction reaction coil together with the reducing agent $0.6 \% \mathrm{NaBH}_{4}$ in $0.5 \% \mathrm{NaOH}$ solution simultaneously with $6 \mathrm{M}$ hydrochloric acid using a peristaltic pump. The $\mathrm{NaBH}_{4}$ reacted with $\mathrm{Se}$ (IV) in the rock extracts in the presence of $\mathrm{HCl}$ to produce the volatile $\mathrm{H}_{2} \mathrm{Se}$. The flow of argon gas into the gas/liquid separator bubbles out the volatile $\mathrm{H}_{2} \mathrm{Se}$ into the quartz absorption cell placed on a burner stem in an air/acetylene flame. The high temperatures of the air /acetylene flame facilitate the atomization of $\mathrm{H}_{2} \mathrm{Se}$ into $\mathrm{H}_{2}$ and Se species. Absorbance recorded at $\lambda_{\mathrm{nm}}=196 \mathrm{~nm}$ was used as the analytical parameter for the quantitation of Se (IV). Each absorbance result was recorded with a pre-read delay of 45 s after sample was introduced into the instrument to enable a steady-state value to be attained before data sampling. Se (VI) is not sensitive in this analytical procedure because it cannot form volatile hydrides.

\section{Procedure for total As and Se analysis using Graphite furnace AAS.}

A $2 \mathrm{~mL}$ aliquot of extracts, $2 \mathrm{~mL}$ of nanopure water (for standard and sample 


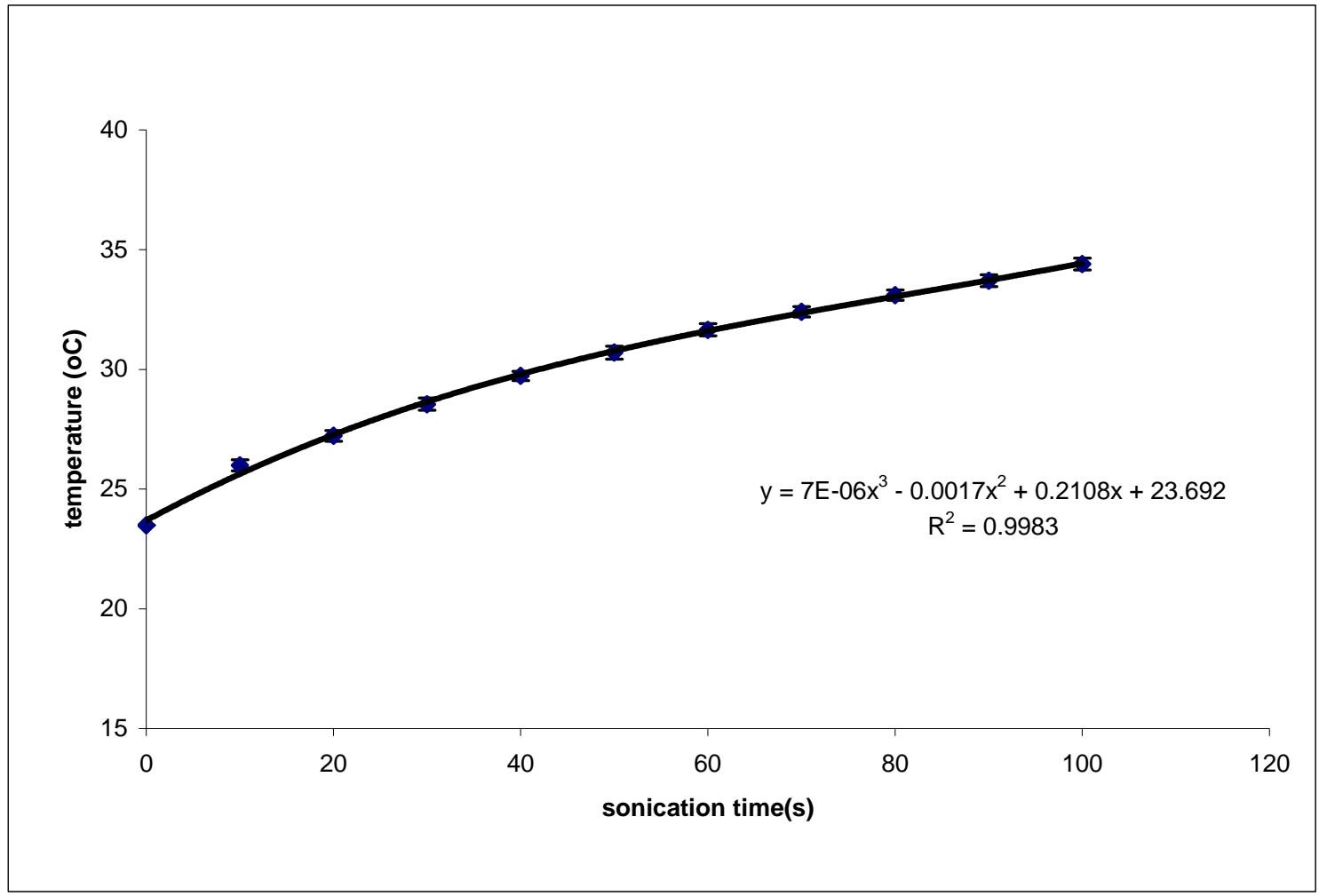

Figure 13: Variation of temperature with sonication time for the larger probe $(1.905 \mathrm{~cm})$ 


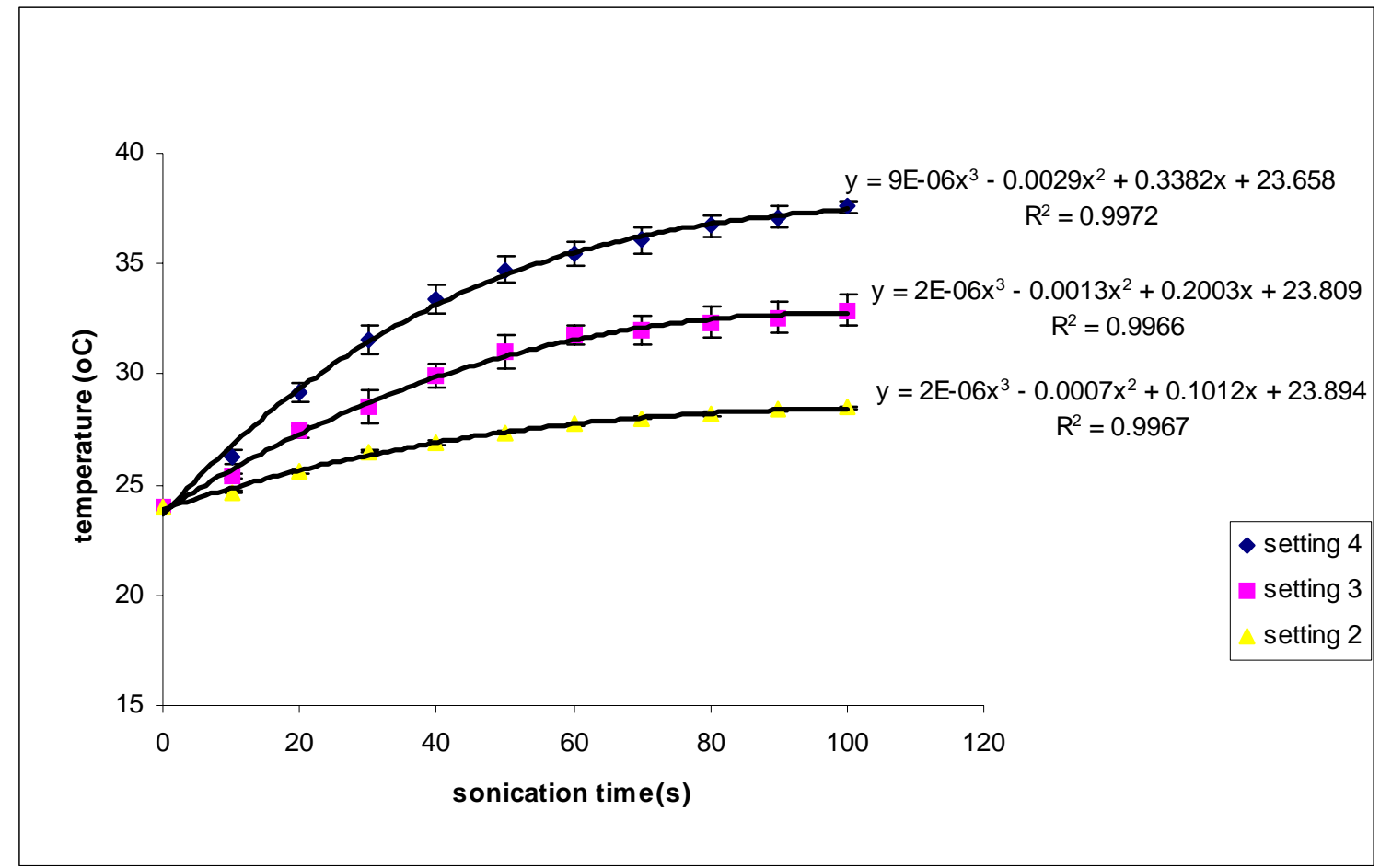

Figure 14: Variation of temperature with sonication time for the smaller probe $(0.3 \mathrm{~cm})$ 


\begin{tabular}{|c|l|l|l|l|}
\hline $\begin{array}{l}\text { Power } \\
\text { setting }\end{array}$ & $\begin{array}{l}(\mathbf{d T} / \mathbf{d t})_{\mathbf{t}}= \\
\mathbf{0}\end{array}$ & $\begin{array}{r}\text { Power } \\
\text { output } \\
\mathbf{W}\end{array}$ & $\begin{array}{l}\text { Power intensity } \\
\left(\mathbf{W} / \mathbf{c m}^{\mathbf{2}}\right)\end{array}$ & $\begin{array}{l}\text { Power per unit } \\
\text { volume } \\
(\mathbf{W} / \mathbf{m L})\end{array}$ \\
\hline $\mathbf{4}$ & 0.3382 & 14.15 & 200.1 & 1.415 \\
\hline $\mathbf{3}$ & 0.2003 & 8.381 & 118.5 & 0.838 \\
\hline $\mathbf{2}$ & 0.1012 & 4.234 & 59.87 & 0.423 \\
\hline
\end{tabular}

Table 1: Power parameters for $0.3 \mathrm{~cm}$ diameter probe in $10 \mathrm{ml}$ water 
dilution purposes only), appropriate $\mathrm{Ni}\left(\mathrm{NO}_{3}\right)_{2} 5 \mathrm{H}_{2} \mathrm{O}$ modifier and the $50 \mathrm{ng} / \mathrm{mL}$ standard for selenium and $100 \mathrm{ng} / \mathrm{mL}$ for arsenic were placed in separate compartments on the sample holder. Samples were individually analyzed for arsenic and selenium. The instrument was programmed to collect $10 \mu \mathrm{L}$ of an extract and $2 \mu \mathrm{L}$ of matrix modifier and to place them together in a graphite tube using an autosampler. The mixtures were then subjected to specific heating programs as outlined in Tables 2 and 3.

The graphite tubes were initially cleaned and conditioned using $2 \mu \mathrm{L}$ of matrix modifier and $10 \mu \mathrm{L}$ of nanopure water before performing any analyses. The averaged absorbencies recorded at $\lambda_{\max }=196 \mathrm{~nm}$ for selenium and $193.7 \mathrm{~nm}$ for arsenic during steps number 6 through 8 (Tables 2 and 3) were used for both standards and samples. Each extract was analyzed nine times using $3 \times 3$ replicate assays.

\section{Procedure for microwave digestion}

A $0.25-0.5 \mathrm{~g}$ sample was placed in each microwave extraction vessel followed by the addition of $5 \mathrm{~mL}$ of $\mathrm{HNO}_{3}, 5-\mathrm{mL}$ of $\mathrm{HF}$ and $3-\mathrm{mL}$ of $\mathrm{HCl}$. The vessels were sealed and placed on the turntable which was placed in the instrument followed by connecting pressure and temperature sensors. Samples were subjected to the heating procedure shown in Table 4. After digestion the solutions were quantitatively transferred to $50-\mathrm{ml}$ volumetric flasks and then to polyethylene vials for storage. The digests were analysed for total arsenic and selenium in triplicate using graphite furnace atomic absorption spectrometry.

\section{Results and Discussion}

\section{Mineralogical examination of pulverized rocks}

Mineral analyses of pulverized rocks were previously performed by the West Virginia 


\begin{tabular}{|l|l|l|l|l|}
\hline Step & $\begin{array}{l}\text { Temperature } \\
\left({ }^{\mathbf{}} \mathbf{C}\right)\end{array}$ & Time(s) & $\begin{array}{l}\text { Argon gas } \\
\mathbf{f l o w} \\
\mathbf{( L / m i n})\end{array}$ & Stage activity \\
\hline 1 & 85 & 5.0 & 3.0 & Drying \\
\hline 2 & 95 & 40.0 & 3.0 & Drying \\
\hline 3 & 120 & 10.0 & 3.0 & Drying \\
\hline 4 & $\mathbf{1 0 0 0}$ & 8.0 & 3.0 & Char/ash \\
\hline 5 & $\mathbf{1 0 0 0}$ & 1.0 & 3.0 & Char/ash \\
\hline 6 & $\mathbf{1 0 0 0}$ & 2.0 & 0.0 & $\begin{array}{l}\text { Char/ash } \\
\text { and signal } \\
\text { sampling }\end{array}$ \\
\hline 7 & 2600 & 0.8 & 0.0 & $\begin{array}{l}\text { Atomization } \\
\text { signal sampling }\end{array}$ \\
\hline 8 & 2600 & 2.0 & 0.0 & $\begin{array}{l}\text { Atomization } \\
\text { signal sampling }\end{array}$ \\
\hline 9 & 2600 & 2.0 & 3.0 & \begin{tabular}{l} 
Tube clean \\
\hline
\end{tabular} \\
\hline
\end{tabular}

Table 2: GFAAS program for selenium analysis (Adapted from Varian 55 B spectrometer methods manual) 


\begin{tabular}{|l|l|l|l|l|}
\hline Step & $\begin{array}{l}\text { Temperature } \\
\left({ }^{\mathbf{}} \mathbf{C}\right)\end{array}$ & Time(s) & $\begin{array}{l}\text { Argon gas } \\
\mathbf{f l o w} \\
(\mathbf{L} / \text { min) }\end{array}$ & Stage activity \\
\hline 1 & 85 & 5.0 & 3.0 & Drying \\
\hline 2 & 95 & 40.0 & 3.0 & Drying \\
\hline 3 & 120 & 10.0 & 3.0 & Drying \\
\hline 4 & $\mathbf{1 4 0 0}$ & 8.0 & 3.0 & Char/ash \\
\hline 5 & $\mathbf{1 4 0 0}$ & 1.0 & 3.0 & Char/ash \\
\hline 6 & $\mathbf{1 4 0 0}$ & 2.0 & 0.0 & $\begin{array}{l}\text { Char/ash } \\
\text { signal sampling }\end{array}$ \\
\hline 7 & 2600 & 0.6 & 0.0 & $\begin{array}{l}\text { Atomization } \\
\text { signal sampling }\end{array}$ \\
\hline 8 & 2600 & 2.0 & 0.0 & $\begin{array}{l}\text { Atomization } \\
\text { signal sampling }\end{array}$ \\
\hline 9 & 2600 & 2.0 & 3.0 & Tube clean \\
\hline
\end{tabular}

Table 3: GFAAS program for arsenic analysis (Adapted from Varian 55 B spectrometer methods manual) 
Geological and Economic Survey (WVGES). The results obtained indicated that BT60 was sandstone, while BT571 and BT700 were claystones. Sample BT60 was comprised of $81 \% \mathrm{SiO}_{2}$, most of which was present as quartz as shown in Tables 5 and 6 . Samples BT571 and BT700 had $62.25 \%$ and $63.83 \% \mathrm{SiO}_{2}$ of which about half of BT571 and about a third of BT700 was quartz. The two claystone samples contained about six times the percentage of illite as that in BT60. There were no significant differences in kaolin composition in the three samples as indicated in Table 5. The $\mathrm{Fe}_{2} \mathrm{O}_{3}$ and \% $14 \AA$ clays compositions in BT60 were below $0.01 \%$ as shown in Tables 5 and 6 .

\section{Comparison of extraction methods}

Many of the kinetic batch extraction experiments reported in the literature were carried out at aqueous concentrations that are higher than those found in natural environments. In these studies, pure solids (e.g. kaolin, silica, illite, iron oxides) were equilibrated with organic or inorganic substances of interest to allow adsorption onto the solid surfaces prior to performing the desorption experiments. As a result of the concentrations used in such adsorption and desorption experiments, kinetic studies are limited due to the equilibrium conditions that are quickly established during the onset of extractions. ${ }^{89}$ It is preferable to use continuous flow methods because there is no re-adsorption of the materials that were released earlier into the solution. ${ }^{90-95}$ The initial extractions in the batch experiments release most of the metals capable of being extracted; therefore during the first extraction, there is a greater chance of establishing equilibrium between the adsorbed and free metals in solution. The concentrations obtained in this manner cannot be used to describe the kinetics of extraction, but rather only describe equilibrium conditions. ${ }^{96}$ This prompted the use of temperature-jump 


\begin{tabular}{|l|l|}
\hline Parameter & Reading \\
\hline Power & $1200 \mathrm{~W}$ \\
\hline Heating program & $\begin{array}{l}15 \mathrm{~min} \text { ramp to } \\
190{ }^{\circ} \mathrm{C} \text { and } 15 \\
\text { min hold time at } \\
190^{\circ} \mathrm{C}\end{array}$ \\
\hline Time & $30 \mathrm{~min}$ \\
\hline Temperature & $190{ }^{\circ} \mathrm{C}$ \\
\hline Fan Speed & 100 \\
\hline
\end{tabular}

Table 4: Microwave acid digestion heating program. 


\begin{tabular}{|c|c|c|c|c|c|c|c|}
\hline Sample & Lithology & $\begin{array}{c}\% \\
\text { Quartz }\end{array}$ & $\begin{array}{c}\text { Orthoclase } \\
\text { K- } \\
\text { Feldspar }\end{array}$ & $\begin{array}{c}\% \\
\text { Plagioclase } \\
\text { (Na/Ca } \\
\text { Feldspar) }\end{array}$ & $\begin{array}{c}\% \\
\text { Illite }\end{array}$ & $\begin{array}{c}\% \\
\text { Kaolinite }\end{array}$ & $\begin{array}{c}\% 14 \AA \\
\text { Clays }\end{array}$ \\
\hline BT60 & Sandstone & 81.0 & 3.2 & $<0.1$ & 6.8 & 9.1 & $<0.01$ \\
\hline BT571 & Claystone & 32.1 & 0.4 & 0.5 & 40.1 & 12.2 & 14.7 \\
\hline BT700 & Claystone & 22.6 & 0.5 & 0.9 & 46.6 & 7.5 & 21.9 \\
\hline
\end{tabular}

Table 5: X-ray diffraction results

Courtesy, West Virginia Geological and Economic Survey (WVGES) ${ }^{7}$ 


\begin{tabular}{|l|l|l|l|l|l|l|l|l|l|}
\hline & $\%$ & $\%$ & $\%$ & $\%$ & $\%$ & $\%$ & $\%$ & $\%$ & $\%$ \\
\hline BT60 & 0.01 & 2.48 & 81.05 & 15.28 & $<.01$ & 0.07 & 0.48 & 0.86 & 0.22 \\
\hline BT571 & 0.04 & 4.91 & 62.25 & 23.95 & 5.17 & 0.05 & 2.15 & 1.34 & 0.04 \\
\hline BT700 & 0.03 & 5.52 & 63.83 & 23.28 & 4.16 & 0.19 & 1.97 & 1.27 & $<0.01$ \\
\hline
\end{tabular}

Table 6: X-ray fluorescence results

Courtesy, West Virginia Geological and Economic Survey (WVGES) ${ }^{7}$ 
experiments to study the adsorption and desorption kinetics of selenate and selenite at goethite surfaces. ${ }^{97}$ In order to establish that equilibrium was not reached during the first 5 minutes of ultrasonic extraction, results for 120 minutes of continuous sonication were compared with those obtained from the initial 5 minutes of sonication of a 90 -minute sequential extraction experiment consisting of 5 minute ultrasonic extractions. The concentrations of total arsenic and selenium obtained by different extraction methods and microwave digestions are summarized in Table 7.

Although there was a large initial increase for both the arsenic and selenium concentration obtained during the first five minutes of the 90-minute sequential extraction, there is a statistically significant difference in the values obtained after first 5 minutes of the 90 minute sequential extraction to the Se concentration that was extracted after 120 minutes of continuous sonication $(P \leq 0.11, n=9)$. This suggests that the concentration of both metals in solution obtained after five minutes of extraction would not have reached equilibrium with arsenic and selenium still encapsulated, sorbed or remaining within the pulverized rock particles.

The mass of selenium and arsenic per g sample obtained after 2 hours of continuous sonication were smaller than the values obtained by the 90 -minute sequential sonication. These data indicate equilibration and/or readsorption could have been established during the course of the 2-hour extraction. In order to promote the non-equilibrium conditions needed for kinetic studies to simulate the flowing stream conditions, it was necessary to use the sequential extraction method. Thus the observed non-equilibrium conditions at 5 minutes of ultrasonication time at $200 \mathrm{~W} / \mathrm{cm}^{2}$ of ultrasonication power could be described in terms of a slow readsorption process of the 
released metals compared to a faster desorption rate. These extraction conditions were used to simulate the accelerated kinetic release of selenium and arsenic from valley fills into streams.

The amount of arsenic extracted with ultrasound was three orders of magnitude greater $(\mu \mathrm{g} / \mathrm{g}$ vs. $\mathrm{ng} / \mathrm{g})$ than the selenium as shown in Figures 15 and 16. No arsenic was previously detected in the stream waters ${ }^{7}$, even though the accelerated rate constants appeared to be ten times greater than those for selenium (Table 8). This suggests that arsenic could be sequestered from the aqueous phase by a different mechanism compared to selenium. Quaghebeur ${ }^{98}$ examined the desorption of arsenic from kaolin using a first order two-site model, where the rate constants were determined for the desorption from fast and slow sites. The first order rate constant for the fast site ranged from 0.029-0.069 $\min ^{-1}$ depending on $\mathrm{pH}$.

The rate constants for arsenic for the three samples in our study ranged from 0.013-0.050 $\mathrm{min}^{-1}$ as shown in Table 8. The $\mathrm{pH}$ for sample solutions of BT571 ranged from 6.4-7.8 and from 9.3-9.8 for solutions of BT701. According to Bryant et $\mathrm{al}^{7}$, stream water $\mathrm{pH}$ from the regions affected by MTR/VF mining activities in southern West Virginia ranged from $6.0-9.0$. The $\mathrm{pH}$ values obtained for sample solutions ranged from 6.3 -9.6 and values are close to the ones found by Bryant et al. ${ }^{7}$ (Figure 17).

Sample BT60 was found to have the lowest concentrations of arsenic and selenium compared to BT571 and BT700 as shown in Table 7. Although BT700 had the highest total and extractable arsenic and selenium species, the rates of their releases from the solid into the solution were smaller than those of BT571 and BT60 as shown in Table 8. 
The rate of release of total arsenic and total selenium did not depend on their respective concentrations in rocks but rather on the type of rocks analysed. Although sample BT60, a sandstone, contained the lowest amounts of selenium, selenium extraction was completed during the first three extractions. Jenkins and Schaer ${ }^{99}$ found that darker overburden with large amounts of humic and fulvic substances had the highest selenium concentrations. Their observations were consistent with our findings in that the claystones (BT700 and BT571) were dark in appearance and had the highest amounts of selenium and arsenic (Table 7).

Organic acids which originate from dead plants are often incorporated into rocks during rock formation. Any selenium that is bound to organic acids can become part of the rock and some of this sorbed selenium can become bioavailable as the rocks weather $100,101$.

\section{Effects of ultrasonic power on the speciation studies for Se (IV)/ Se (VI) and As (III)/As (V)}

In order to determine the effects of ultrasonic power on the speciation of arsenic and selenium, solutions of As (III)/As (V) and Se (IV)/Se (VI) in a 1:1 ratio were separately monitored as a function of ultrasonication time using $200 \mathrm{~W} / \mathrm{cm}^{2}$ power intensity. A fresh 10-ml solution of $5 \mathrm{ng} / \mathrm{L}$ arsenic /selenium was sonicated for each of the following sonication times ( $5 \mathrm{~min}, 10 \mathrm{~min}, 15 \mathrm{~min} \ldots$ up to 2 hours). All experiments were done in triplicate. As illustrated in Figure 18, the As (III) concentration decreased by $70 \%$ after only five minutes of sonication followed by a slow decrease to reach values that are $96 \%$ lower than the initial concentration within a period of two hours. Solutions containing 1:1 mixtures of 5, 10 and $15 \mathrm{ng} / \mathrm{mL}$ of As (III) and As (V) also showed similar trends. Hence, ultrasonication extraction cannot be applied for the speciation studies of 


\begin{tabular}{|c|c|c|c|c|c|c|c|c|}
\hline & Total available & \multicolumn{3}{|c|}{ Total Selenium Extracted } & \multirow{2}{*}{$\begin{array}{l}\text { Total available } \\
\text { Arsenic }\end{array}$} & \multicolumn{3}{|c|}{ Total Arsenic extracted } \\
\hline Sample & $\begin{array}{l}\text { Microwave } \\
\text { digestion } \\
\mathrm{ng} / \mathrm{g} \times 10^{3}\end{array}$ & $\begin{array}{l}120 \text { min } \\
\text { continuous } \\
\text { sonication } \\
\mathrm{ng} / \mathrm{g} \mathrm{x} 10^{3}\end{array}$ & $\begin{array}{l}\text { Partial } 5 \\
\text { minute of the } \\
90 \text { minute } \\
\text { sequential } \\
\text { sonication } \\
\mathrm{ng} / \mathrm{g} \times 10^{3}\end{array}$ & $\begin{array}{l}\text { Total } 90 \\
\text { minute } \\
\text { sequential } \\
\text { sonication } \\
\mathrm{ng} / \mathrm{g} \times 10^{3}\end{array}$ & & $\begin{array}{l}120 \text { min } \\
\text { continuous } \\
\text { sonication } \\
\mu \mathrm{g} / \mathrm{g}\end{array}$ & $\begin{array}{l}\text { Partial } 5 \\
\text { minute of } \\
\text { the } 90 \\
\text { minute } \\
\text { sequential } \\
\text { sonication } \\
\mu \mathrm{g} / \mathrm{g}\end{array}$ & $\begin{array}{l}\text { Total } 90 \\
\text { minute } \\
\text { sequential } \\
\text { sonication } \\
\mu \mathrm{g} / \mathrm{g}\end{array}$ \\
\hline ВT60 & $0.093 \pm 0.004$ & $\begin{array}{l}0.078 \pm \\
0.003\end{array}$ & $\begin{array}{l}0.0697 \\
0.0003\end{array} \leq$ & $0.093 \pm 0.003$ & $5.1 \pm 0.2$ & $2.2 \pm 0.1$ & $0.8 \pm 0.1$ & $4.2 \pm 0.4$ \\
\hline BT571 & $1.088 \pm 0.002$ & $0.26 \pm 0.02$ & $0.21 \pm 0.04$ & $0.39 \pm 0.01$ & $48 \pm 6$ & $9 \pm 1$ & $9.1 \pm 0.7$ & $12 \pm 1$ \\
\hline BT700 & $1.1 \pm 0.1$ & $0.15 \pm 0.01$ & $0.10 \pm 0.01$ & $0.43 \pm 0.02$ & $62 \pm 5$ & $15 \pm 1$ & $5 \pm 1$ & $28 \pm 2$ \\
\hline
\end{tabular}

Table 7: Comparison of extraction techniques 


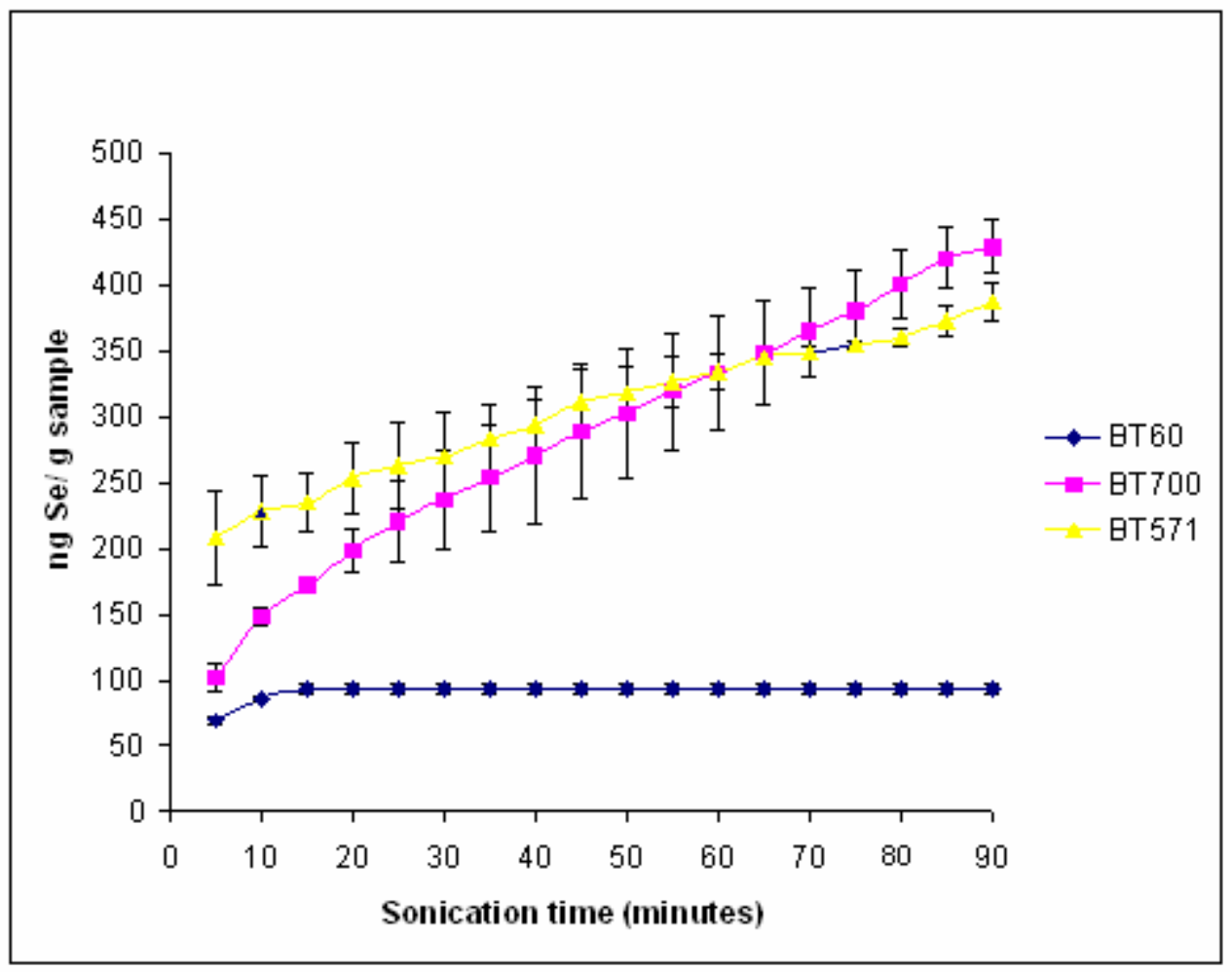

Figure 15: Release of total selenium ( $\mathrm{ppb}$ ) as a function of sonication time

Conditions: Sequential five minute sonications, sonication pulse $40 \%$, probe diameter $0.3 \mathrm{~cm}$, sonication power 200 watts $/ \mathrm{cm}^{2}$, temperature $24 \pm$ $1^{\circ} \mathrm{C} .1 \mathrm{~g}$ sample in $10 \mathrm{~mL}$ nanopure water. 


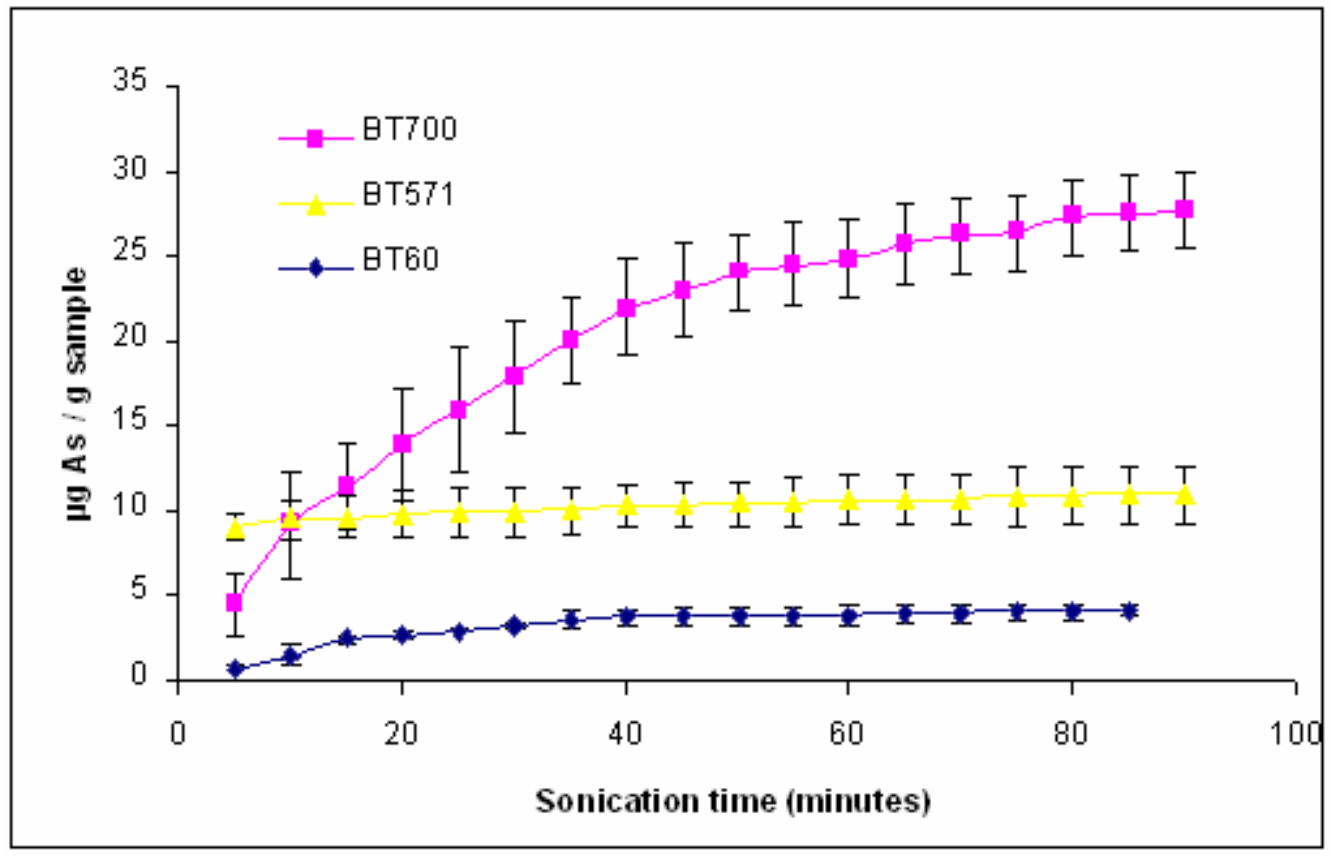

Figure 16: The release of total arsenic $(\mu \mathrm{g} / \mathrm{g})$ as a function of sonication time

Conditions: Sequential five minute sonications, sonication pulse $40 \%$, probe diameter $0.3 \mathrm{~cm}$, sonication power 200 watts $/ \mathrm{cm}^{2}$, temperature $24 \pm$ $1^{\circ} \mathrm{C} .1 \mathrm{~g}$ sample in $10 \mathrm{~mL}$ nanopure water. 


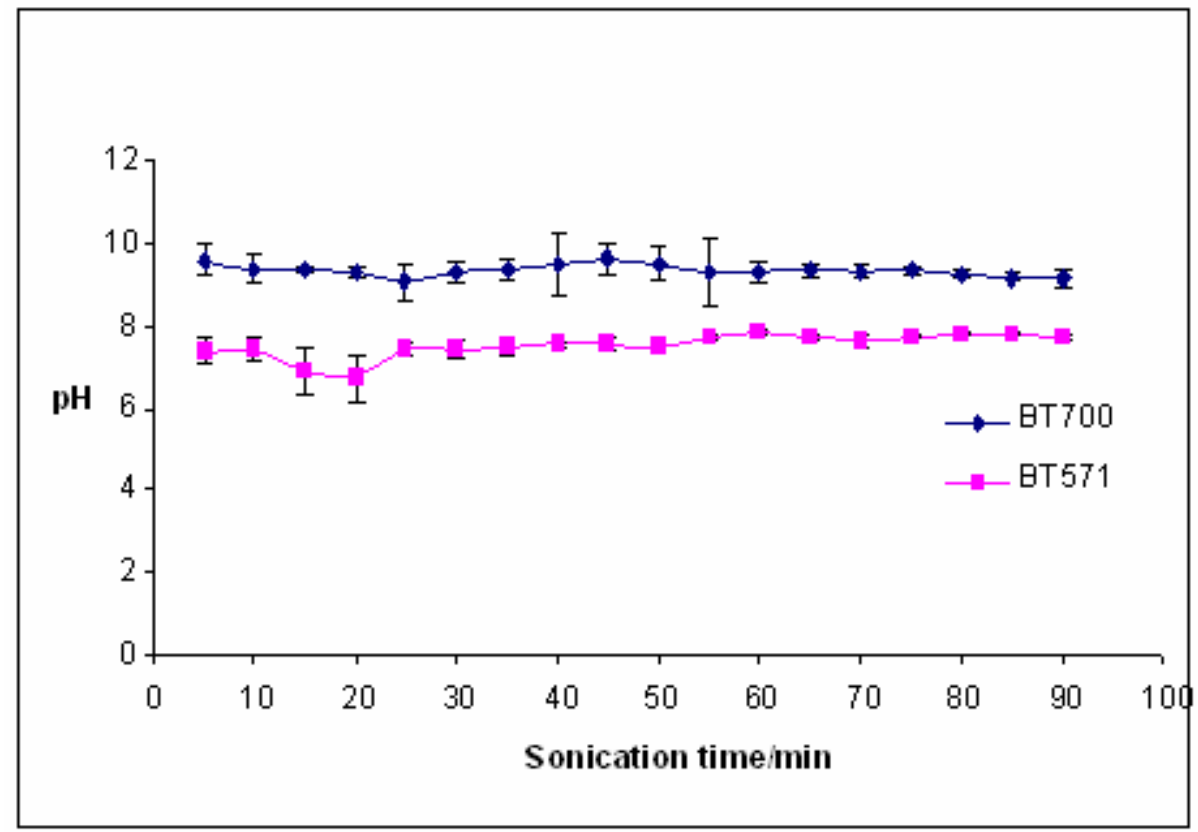

Figure 17: Variation of $\mathrm{pH}$ with sonication time 
arsenic in rocks. Analysis of the total arsenic in the ultrasonicated solutions revealed no arsenic losses.

On the other hand, the Se (IV) concentration remained constant over the entire 120 minutes of continuous sonication. No significant changes in total selenium concentration were observed after a two-hour continuous sonication of 5,10 and $15 \mathrm{ng} / \mathrm{mL}$ of $1: 1 \mathrm{Se}$ (IV)Se (VI) mixtures. Hence, Se (IV) solutions are not easily oxidized under the experimental conditions used.

In the core samples analysed, it appears there are two forms of bound selenium, with one weakly sorbed and the other strongly sorbed. The weakly sorbed forms are readily available and the strongly sorbed take more time and energy to become bioavailable. This information could explain the fact that samples BT571 and BT700 had more selenium which was not readily leachable compared to BT60. Peak and Sparks ${ }^{102}$ found that selenate and selenites both bind strongly to iron oxides. The low iron content in BT60 could be a possible reason the selenium in BT60 was easily extracted compared to BT571 and BT700 (Table 8). Such kinetic information is useful in determining procedures that should be undertaken when disposing different types of mining waste. Another complication is that the toxicity and bioavailability of the released metalloids depend on chemical speciation which suggests the need to differentiate the selenium and arsenic compounds released. The reactivity and toxicity of arsenic and selenium depend on their oxidation states

In BT700 most of the extractable selenium is Se (IV) whereas in BT571 the predominant form is Se (IV) as shown in Figures 19 and 20. The Se (IV) concentration increased in the order BT60<BT571 $<$ BT700. BT60 was collected closer to the surface 
where conditions are more oxidizing had no detectable Se (IV) concentrations and BT700 was collected at much lower depth where conditions are more reducing and had the highest Se (IV) concentrations. The rate constants for Se (IV) are of the same order of magnitude in BT700 and BT571 (Table 9) suggesting that Se (IV) could be associated with same type of lithological rock inclusions in different rocks. 


\begin{tabular}{|c|c|c|c|c|}
\hline \multirow[t]{2}{*}{ Sample } & \multicolumn{2}{|c|}{$\mathrm{Se}$} & \multicolumn{2}{|c|}{ As } \\
\hline & $\begin{array}{l}{ }^{\mathbf{b}} \text { Rate constant } \\
\min ^{-1}\end{array}$ & $R^{2}$ value & $\begin{array}{l}{ }^{\mathbf{b}} \text { Rate constant } \\
\text { min }^{-1}\end{array}$ & $\mathrm{R}^{2}$ value \\
\hline BT $60^{\mathrm{a}}$ & - & - & $0.050 \pm 0.003$ & 0.9404 \\
\hline BT571 & $0.0089 \pm 0.0002$ & 0.9474 & $0.013 \pm 0.003$ & 0.9847 \\
\hline BT700 & $0.0052 \pm 0.0001$ & 0.9949 & $0.034 \pm 0.001$ & 0.9950 \\
\hline
\end{tabular}

Table 8: Accelerated first order kinetic modeling for the extraction of total Se and total As

${ }^{a}$ Not enough data points were available for total Se kinetic modeling. All Se was leached out in the first three extractions.

${ }^{\mathbf{b}}$ Accelerated extraction rate constant \pm standard error of the slope obtained from First order model $\ln \left(\mathbf{1}-\mathbf{B}_{\mathbf{t}} / \mathbf{B}_{\infty}\right)=-\mathbf{k}_{\mathbf{o b s e r v e d}} \cdot \mathbf{t}$, where $\mathbf{B}_{\mathbf{t}}$ is the concentration of extracted species at sonication time $\mathbf{t}$ and $\mathbf{B}_{\infty}$ is the extracted species concentration at infinite sonication, $\mathbf{k}_{\mathbf{o b s e r v e d}}$ is the apparent accelerated extraction rate constant 


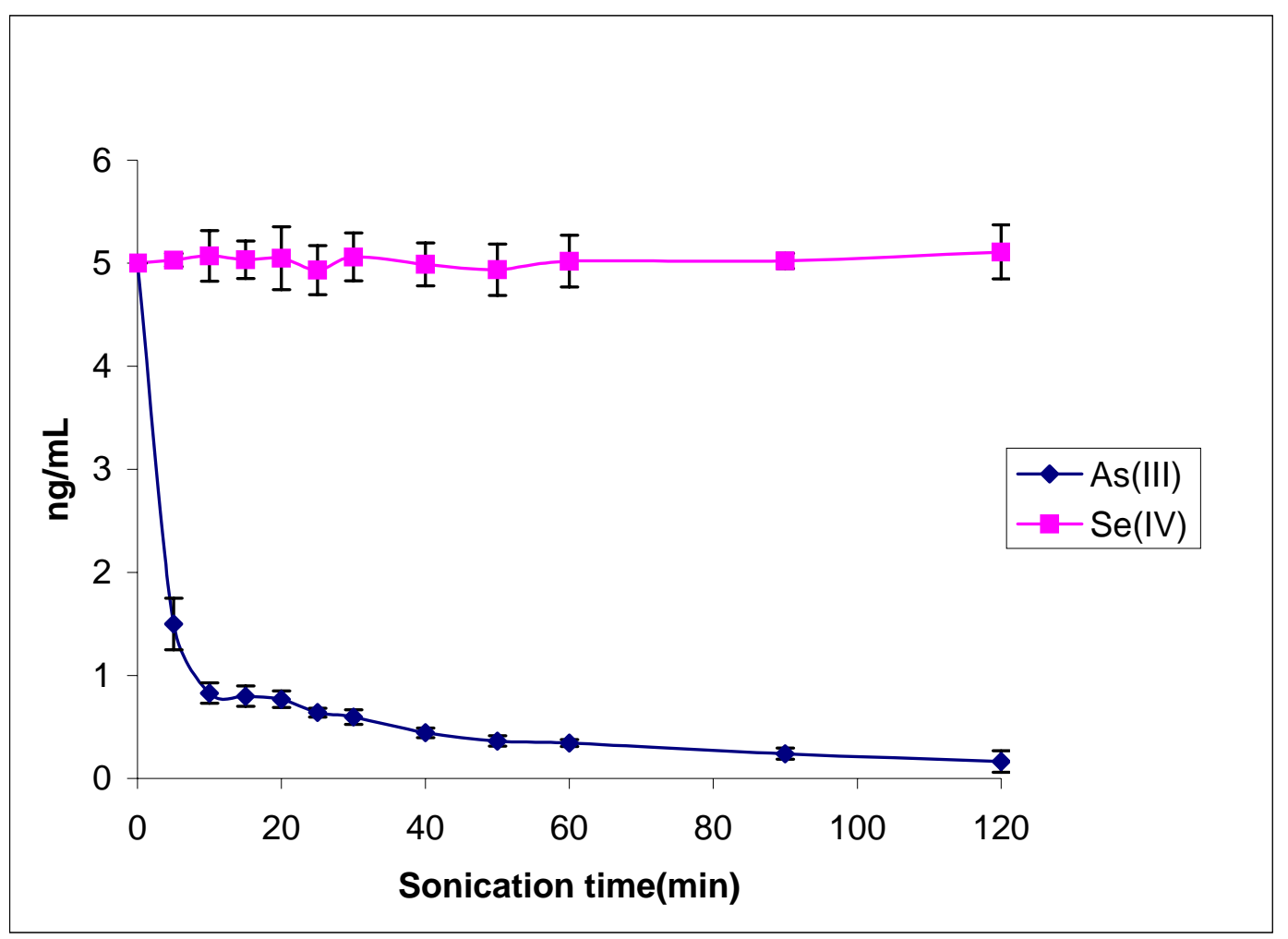

Figure 18: Variation of Se (IV) and the disappearance of As (III) as a function of sonication time

Conditions: $10 \mathrm{ml}$ solutions of $5 \mathrm{ng} / \mathrm{ml}$ of $1: 1 \mathrm{Se}$ (IV)/Se (VI) and As (III)/As (V) sonicated at $200 \mathrm{~W} / \mathrm{cm}^{2}$, continuous sonication, sonication pulse $40 \%$, probe diameter $0.3 \mathrm{~cm}$, temperature $=24 \pm 1^{\circ} \mathrm{C}$. 


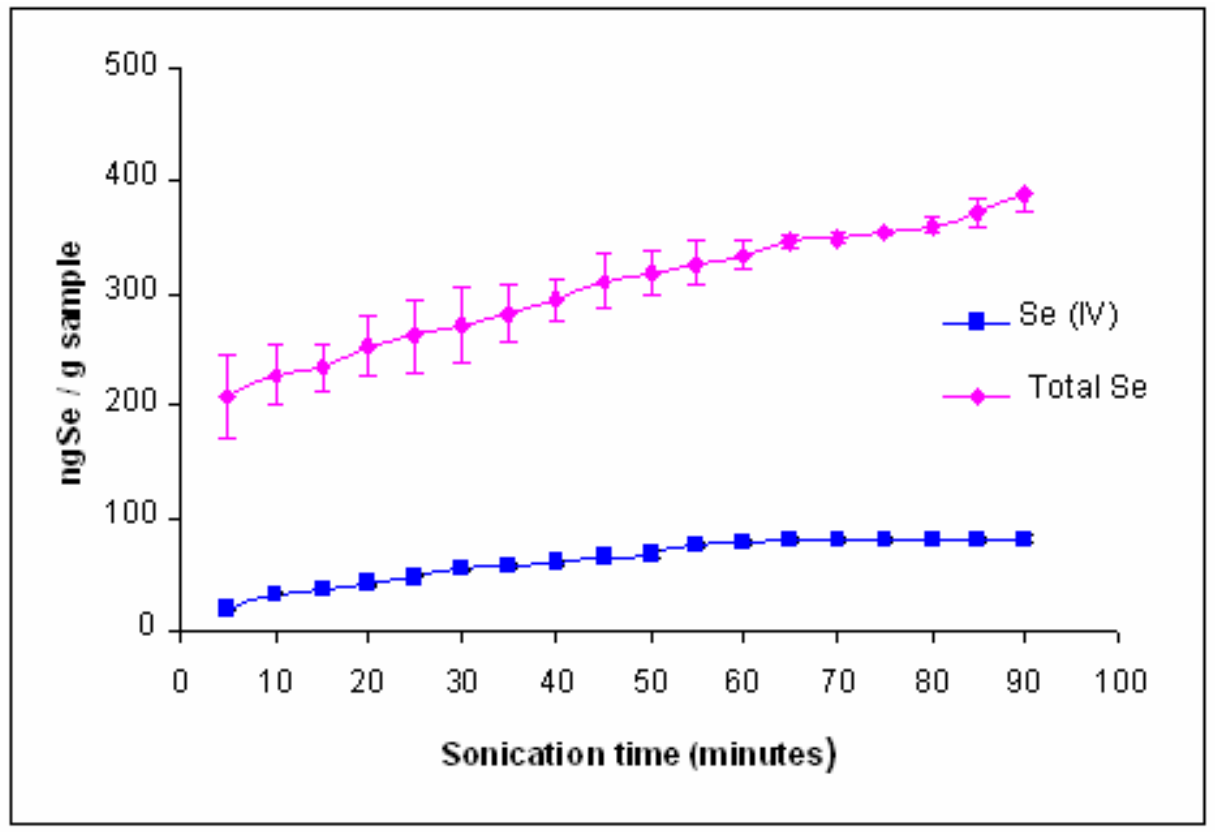

Figure 19: The release of total Se and Se (IV) from BT571 as function of sonication time Conditions: Sequential five minute sonications, sonication pulse $40 \%$, probe diameter 0.3 $\mathrm{cm}$, sonication power $200 \mathrm{watts} / \mathrm{cm}^{2}$, temperature $24 \pm 1^{\circ} \mathrm{C} .1 \mathrm{~g}$ sample in 10 $\mathrm{mL}$ nanopure water. 


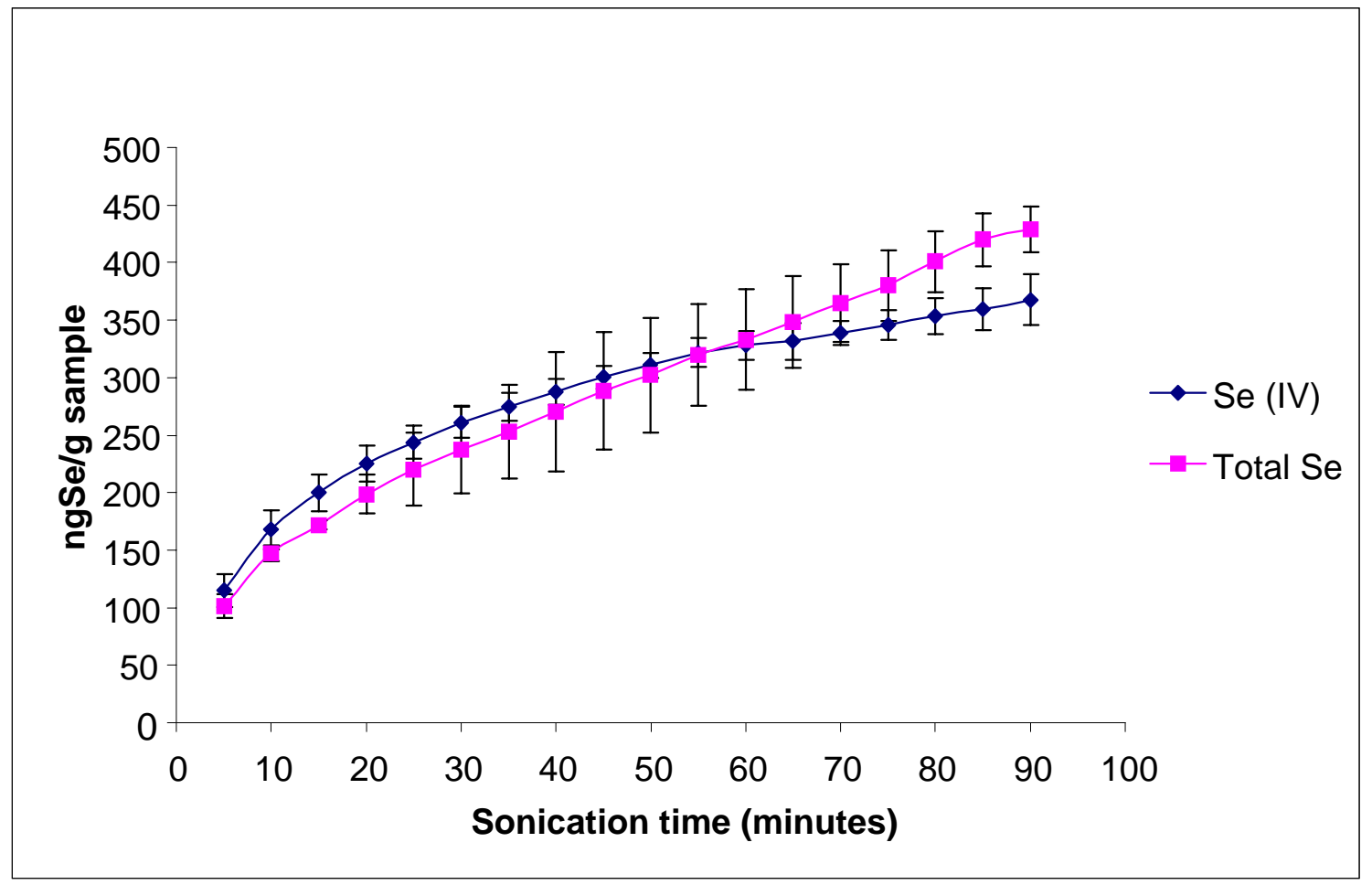

Figure 20 : The release of total Se and Se (IV) from BT700 as a function of sonication time Conditions: Sequential five minute sonications, sonication pulse $40 \%$, probe diameter 0.3 $\mathrm{cm}$, sonication power 200 watts $/ \mathrm{cm}^{2}$, temperature $24 \pm 1^{\circ} \mathrm{C} .1 \mathrm{~g}$ sample in $10 \mathrm{~mL}$ nanopure water. 


\begin{tabular}{|l|l|l|}
\hline Sample & Rate constant $\left(\mathrm{min}^{-1}\right)$ & $\mathrm{R}^{2}$ value \\
\hline BT571 & $0.034 \pm 0.002$ & 0.9837 \\
\hline BT700 & $0.026 \pm 0.001$ & 0.9905 \\
\hline
\end{tabular}

Table 9: First order kinetic modeling for the release of Se (IV) 


\section{Summary}

Ultrasound extraction in nanopure water is a powerful and efficient tool for the extraction of metals and organics from soils, sediments, and biological materials.

Ultrasound dissolution is a useful tool for the kinetic extraction of arsenic and selenium and the speciation of selenium from coal-associated rocks.

The release of arsenic and selenium from coal-associated rocks depend both on the type of rock and the concentrations found in rocks. These metalloids are released at different rates indicating that they bound at different sites and by different mechanisms.

The extracted arsenic concentrations are 3 orders of magnitude higher than selenium concentrations, and the speciation of the extracted selenium is also dependent on the rock material. Additional work must be done to determine the type of binding and the locations of arsenic and selenium in these coal-associated rocks as well as the fate of arsenic and selenium that have been leached from valley fills. 


\section{Chapter 3: Sonochemical Extraction of Arsenic and Selenium from Coal Mining Associated Rocks: Estimation of Bioavailable Concentrations.}

\section{Introduction}

Considering the potential toxicity of the selenium and arsenic liberated from the waste rocks, it was useful to develop a method that can quickly and efficiently be used to analyze for bioavailable selenium and arsenic before the solid waste is deposited in valleys. Such an arrangement can then allow suitable waste treatment methodologies to be applied before depositing arsenic and selenium laden waste in valleys.

\section{Experimental}

\section{Materials and Methods}

Four pulverized rock samples (WVGES), previously sieved through a $60 \mu \mathrm{m}$ mesh, were each subjected to twelve parallel batch sonicated extractions in nanopure water. Each extraction was done in multiples of 5 minutes of continuous sonication up to a period of one hour. The mixtures were then centrifuged at $3400 \mathrm{~g}$ for 20 minutes and then supernatant solutions were decanted with a Pasteur pipette and placed in cleaned and previously acid soaked $25 \mathrm{~mL}$ polyethylene vials. Filtration through a $0.45 \mu \mathrm{m}$ filter paper gave comparable results to the ones obtained by centrifugation. The extracts were analyzed for total selenium and arsenic by graphite furnace atomic absorption spectrophotometer and Se (IV) by hydride generation atomic absorption spectrometry. Total available selenium and arsenic were obtained by microwave digestion.

Particle size distributions for each sonicated fraction were determined using a Shimadzu SALD 3101 laser diffraction particle analyzer after the particles were freeze 
dried to preserve their chemical and physical surface characteristics. ${ }^{103}$ The flow diagram for the particle size measurements is shown in Figure 21. A $1 \%$ suspension of each pulverized rock sample was placed in the built in sonication bath at $40 \mathrm{~W}$ for complete dispersion. The suspensions were later allowed to pass through the optical paths of the instrument for particle size distribution measurements.

\section{Sequential extraction ${ }^{104,105}$}

The procedure used for the sequential extraction (Figure 22) is a modification of the Tessier's method.$^{56}$

\section{(i) Water soluble}

A $1.0 \mathrm{~g}$ sample and $10 \mathrm{~mL}$ nanopure water were mixed in a $20-\mathrm{ml}$ polyethylene vial on an end over mechanical shaker for two hours spinning at 90 revolutions per minute. The mixture was centrifuged for 20 minutes at $3400 \mathrm{~g}$. The clear supernatant liquid was siphoned with a pasteur pipette without disturbing the settled residue into a cleaned and previously acid soaked polyethylene vial. The residue was washed with $1 \mathrm{ml}$ nanopure water and the washings were decanted and disregarded. The experiments were done in triplicate.

\section{(ii) Exchangeable}

The residue from the water soluble fraction was transferred quantitatively into a 20-mL polyethylene vial using $10 \mathrm{~mL}$ of $0.1 \mathrm{M} \mathrm{Na}_{2} \mathrm{PO}_{4}-\mathrm{NaHPO}_{4}$ at $\mathrm{pH}$ 7. The mixtures were treated the same way as in Step (i)

\section{(iii) Base soluble}

Residues from the exchangeable fraction were each transferred quantitatively into a $20 \mathrm{~mL}$ polyethylene vial using $10 \mathrm{~mL} 0.1 \mathrm{M} \mathrm{NaOH}$. The vials were placed in a water bath maintained at $90{ }^{\circ} \mathrm{C}$ for two hours followed by centrifugation for 20 minutes at $3400 \mathrm{~g}$ 


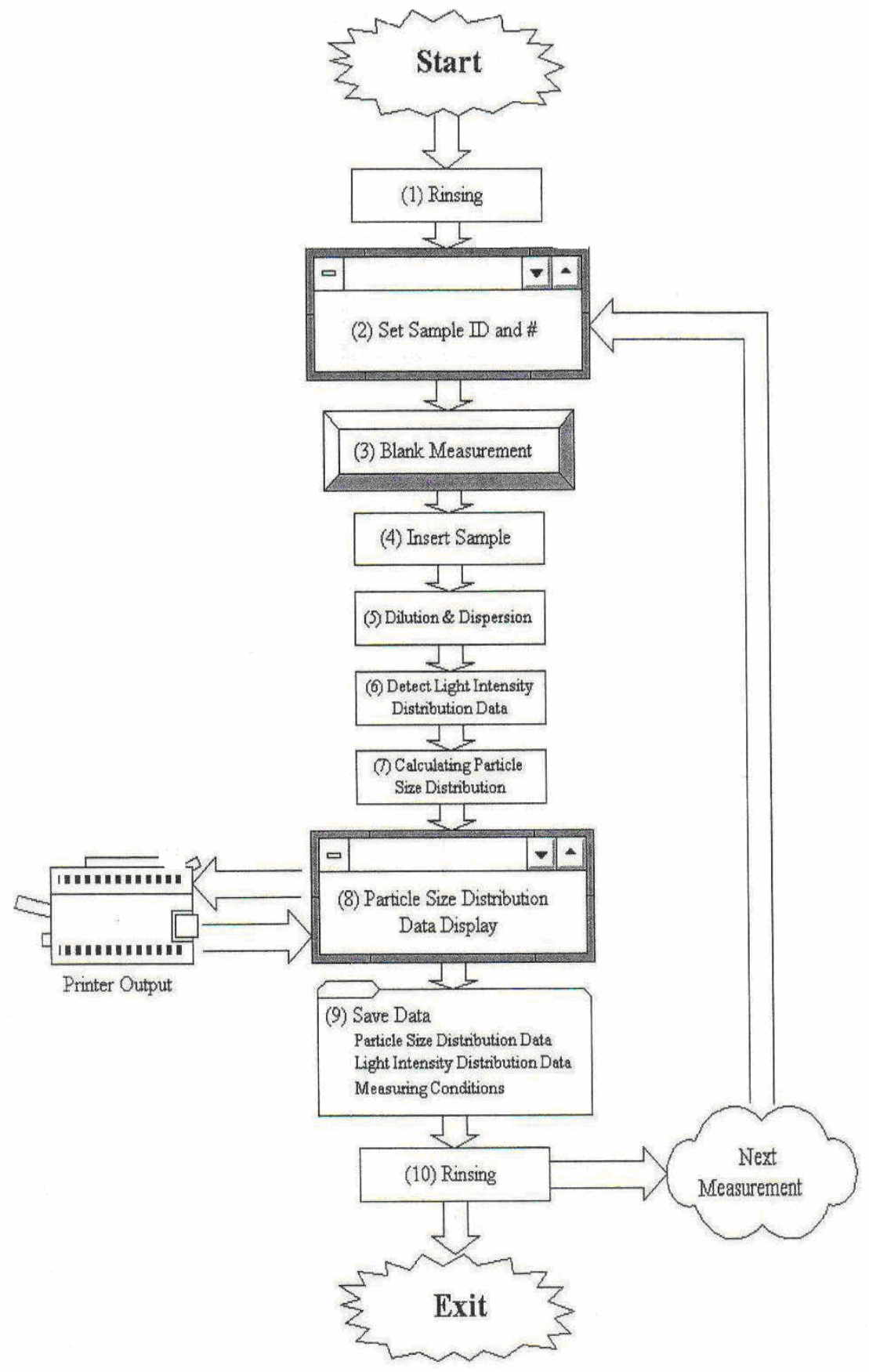

Figure 21: Particle size measurement flow process using SALD ( From SALD 3101 operation manual ) 
force. The mixtures were then treated the same way as in step (i).

\section{(iv) Elemental Se}

Elemental selenium dissolves in sulfite solutions to form soluble thioselenate. A 10-mL of aliquot of $0.5 \mathrm{M} \mathrm{Na}_{2} \mathrm{SO}_{3}$ (adjusted to $\mathrm{pH}$ 7) was used to dissolve elemental selenium in the rock residues obtained from the step (iii). The mixtures were sonicated at $200 \mathrm{~W} / \mathrm{cm}^{2}$ for twenty minutes, centrifuged and the supernatant liquid was separated and the remaining residue was used in the following stage.

\section{(v) Acid Soluble}

The residue from step (iv) was transferred quantitatively into a $20 \mathrm{~mL}$ vial using 10 $\mathrm{mL} 15 \%$ acetic acid solution. The solutions were allowed to stand for at least fifteen minutes until the effervescence had subsided. The vials were then placed on an end-over mechanical shaker for two hours to ensure complete dissolution of acid soluble material in the sample. The mixtures were centrifuged followed by separating the supernatant. The residue was dried at $105^{\circ} \mathrm{C}$ for 4 hours. The supernatant solution was analysed for arsenic and selenium.

\section{(vi) Residual}

The dried residue from the acid soluble extraction was microwave digested using a $\mathrm{HF} / \mathrm{HNO}_{3} / \mathrm{HCl}(5: 5: 3)$ acid combination. This fraction is composed of the inert material that is closely associated with siliceous material in rocks. In an attempt to quantitate the reducible diselenides the residue reacted with $\mathrm{CrCl}_{2}{ }^{105}\left(\mathrm{CrCl}_{3}\right.$ passed through a Jones reactor- a column consisting of $2 \% \mathrm{Hg}$ and $98 \% \mathrm{Zn}^{106}$ ) in $5 \mathrm{~mL}$ concentrated $\mathrm{HCl}$. The mixtures were heated at $90{ }^{\circ} \mathrm{C}$ for 2 hours under a stream of $\mathrm{N}_{2}$. 


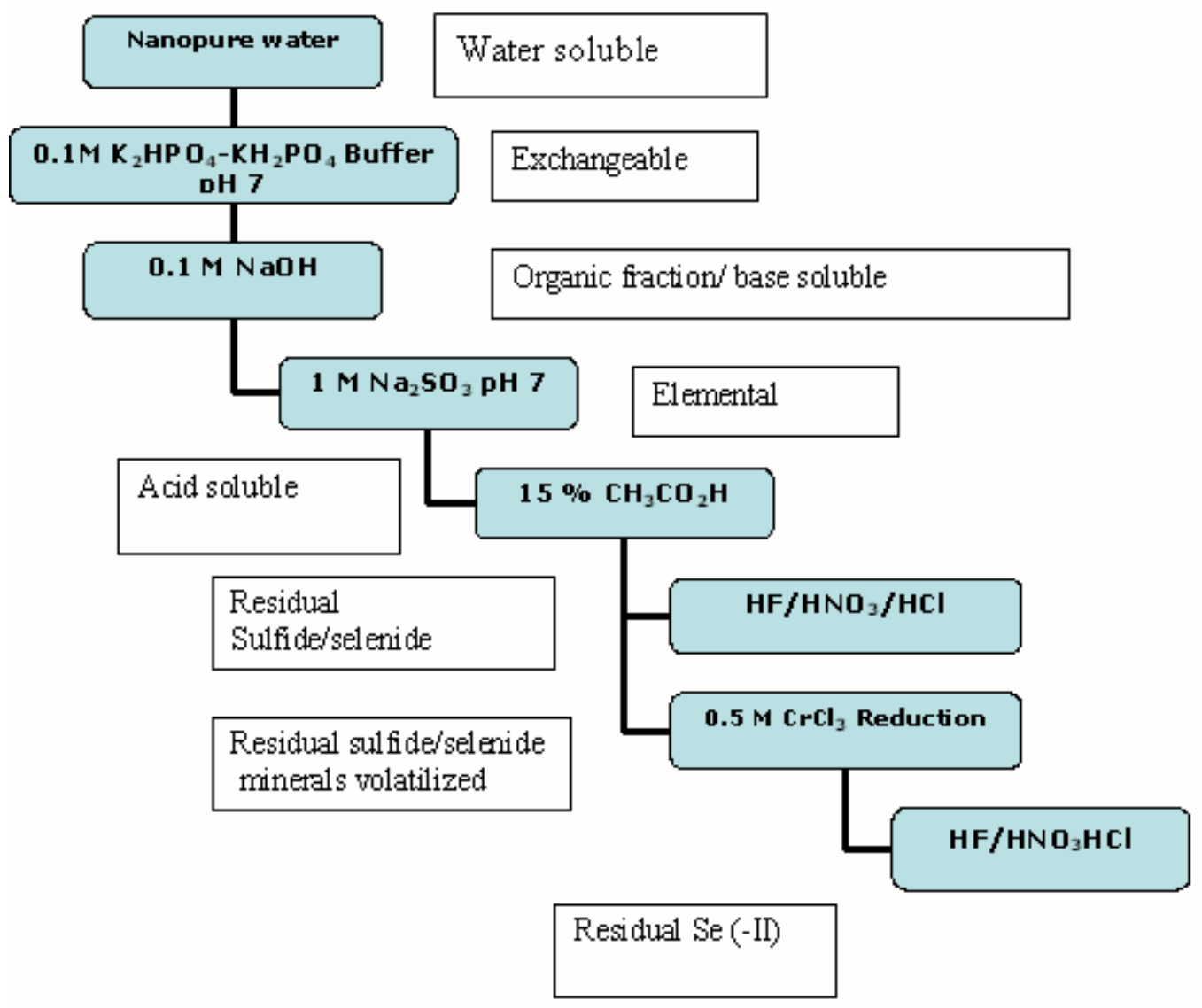

Figure 22: Sequential extraction for selenium ${ }^{104}$ 


\section{Results and discussion}

\section{Batch sonicated extracts}

The sonication of $1 \mathrm{~g}$ samples in $10 \mathrm{~mL}$ nanopure water resulted in slow initial releases of both arsenic and selenium as shown in Figures 23-25. The concentrations peaked at around twenty minutes followed by small decreases thereafter. Continuous sonication for 20 minutes was determined to be the optimal time period required for the release of selenium (Figures 23 and 24) and 25 minutes (Figure 25) for arsenic. The decrease in concentration after 20 minutes is attributed to the resorption of the previously desorbed species and agglomeration of fine particles. ${ }^{107}$ This resorption is facilitated by the formation of smaller particles with a large specific surface area available for adsorption and chemisorption of any chemical species. Since selenium and arsenic require different sonication times for optimal extraction they may occupy different sites in the rock matrix and that arsenic is strongly bound compared to selenium.

The lithologies and mineral inclusions for the four samples are shown in Tables 10 and 11. All samples had appreciable amounts of $\mathrm{Fe}_{2} \mathrm{O}_{3}(0.87-4.82 \%), \mathrm{Al}_{2} \mathrm{O}_{3}(15.70-23.55 \%)$, $\mathrm{K}_{2} \mathrm{O}(2.47-5.75 \%)$ and $\mathrm{MgO}(0.43-2.28 \%)$ with the sandstone (BT61) having the least amounts. $\mathrm{MnO}$ ranged from $0.02-0.05 \%$. The levels of $\mathrm{SiO}_{2}$ were very high $62-79 \%$ and BT61had the highest value of $79.51 \%$.

BT61 had the highest amount of quartz (75.3\%) compared to shale BT241, a shale that had $54.0 \%$ and the two claystones ( BT572 and BT 701) that varied from 25.2-27.7 \%. The variation of 14 Á clays was within $\pm 19 \%$ and illite $\pm 35 \%$ with BT61 having the smallest amounts. Kaolinite composition in all the four samples were within $\pm 5 \%$. 


\section{Particle size}

The particle size distributions of the freeze-dried residues were measured and maximum particle disintegrations were observed to occur between 0 and 25 minutes of continuous sonication as shown in Figures 26 and 27. It follows that the mean particle size decreased and remained almost constant after twenty minutes of continuous sonication (Figure 27). It was also noted that between 20-25 minutes of continuous sonication coincided with highest amounts of arsenic and selenium that were released (Figure 23-25). The ratio between the mean particle size and the modal particle size remained constant throughout the sonication process. This could indicate an existence of uniformity in rock composition and similar disintegration pattern regardless of particle size.

\section{Variation of extracting solvent}

The extracting solvents $4 \mathrm{M} \mathrm{HCl}, 0.1 \mathrm{M} \mathrm{NaOH}$ and $0.1 \mathrm{M} \mathrm{Na}_{2} \mathrm{PO}_{4}-\mathrm{NaHPO}_{4} \mathrm{pH} 7$ were compared by measurement of the concentration of selenium and arsenic released after 20 and 25 minutes of continuous sonication. These solvents were chosen because they are commonly used in the approximation of extractable and bioavailable metals from soils, sediment and sludges as outlined in Chapter 1. The Se (IV) concentrations extracted for each solvent are shown in Figure 28. The extracts were also analyzed for total selenium and total arsenic and the results obtained are shown in Figures 29 and 30, respectively. Comparable concentrations of total selenium were extracted using ultrasound assisted nanopure water, $4 \mathrm{M} \mathrm{HCl}$ and $0.1 \mathrm{M} \mathrm{Na}_{2} \mathrm{PO}_{4}-\mathrm{NaHPO}_{4} \mathrm{pH} 7$ buffer. $10-80 \%$ more Se (IV) and total selenium were extracted using $0.1 \mathrm{M} \mathrm{NaOH}$ compared to other extraction media. 


\begin{tabular}{|l|l|l|l|l|l|l|l|l|l|}
\hline & $\%$ & $\%$ & $\%$ & $\%$ & $\%$ & $\%$ & $\%$ & $\%$ & $\%$ \\
& $\mathrm{MnO}$ & $\mathrm{K}_{2} \mathrm{O}$ & $\mathrm{SiO}_{2}$ & $\mathrm{Al}_{2} \mathrm{O}_{3}$ & $\mathrm{Fe}_{2} \mathrm{O}_{3}$ & $\mathrm{Na}_{2} \mathrm{O}$ & $\mathrm{MgO}$ & $\mathrm{TiO}$ & $\mathrm{CaO}$ \\
\hline BT61 & 0.04 & 2.47 & 79.51 & 15.70 & 0.87 & 0.07 & 0.43 & 1.79 & 0.23 \\
\hline BT241 & 0.02 & 3.88 & 70.40 & 21.41 & 1.57 & 0.00 & 1.48 & 1.46 & 0.01 \\
\hline BT572 & 0.05 & 4.36 & 63.96 & 22.55 & 5.56 & 0.05 & 2.28 & 1.35 & 0.04 \\
\hline BT701 & 0.04 & 5.75 & 62.26 & 23.55 & 4.82 & 0.19 & 2.05 & 1.38 & 0.09 \\
\hline
\end{tabular}

Table 10: X-ray fluorescence data for the samples Courtesy, West Virginia Geological and Economic Survey ${ }^{7}$ 


\begin{tabular}{|l|l|l|l|l|l|l|l|}
\hline Sample & Lithology & $\begin{array}{l}\% \\
\text { Quartz }\end{array}$ & $\begin{array}{l}\% \\
\text { Orthoclase } \\
\text { K- } \\
\text { Feldspar }\end{array}$ & $\begin{array}{l}\% \\
\text { Plagioclase } \\
\text { (Ca/Na } \\
\text { Feldspar })\end{array}$ & $\begin{array}{l}\% \\
\text { Illite }\end{array}$ & $\begin{array}{l}\% \\
\text { Kaolinite }\end{array}$ & $\begin{array}{l}\% \\
\text { Clays }\end{array}$ \\
\hline BT61 & Sandstone & 75.3 & 4.90 & 0.00 & 9.60 & 9.40 & 0.9 \\
\hline BT241 & Shale & 54.0 & 1.90 & 0.90 & 25.7 & 10.9 & 6.70 \\
\hline BT572 & Claystone & 27.7 & 0.80 & 1.20 & 34.6 & 14.5 & 21.0 \\
\hline BT701 & Claystone & 25.2 & 1.20 & 1.30 & 44.9 & 7.60 & 19.8 \\
\hline
\end{tabular}

Table 11: X-ray diffraction data for the samples Courtesy, West Virginia Geological and Economic Survey ${ }^{7}$ 


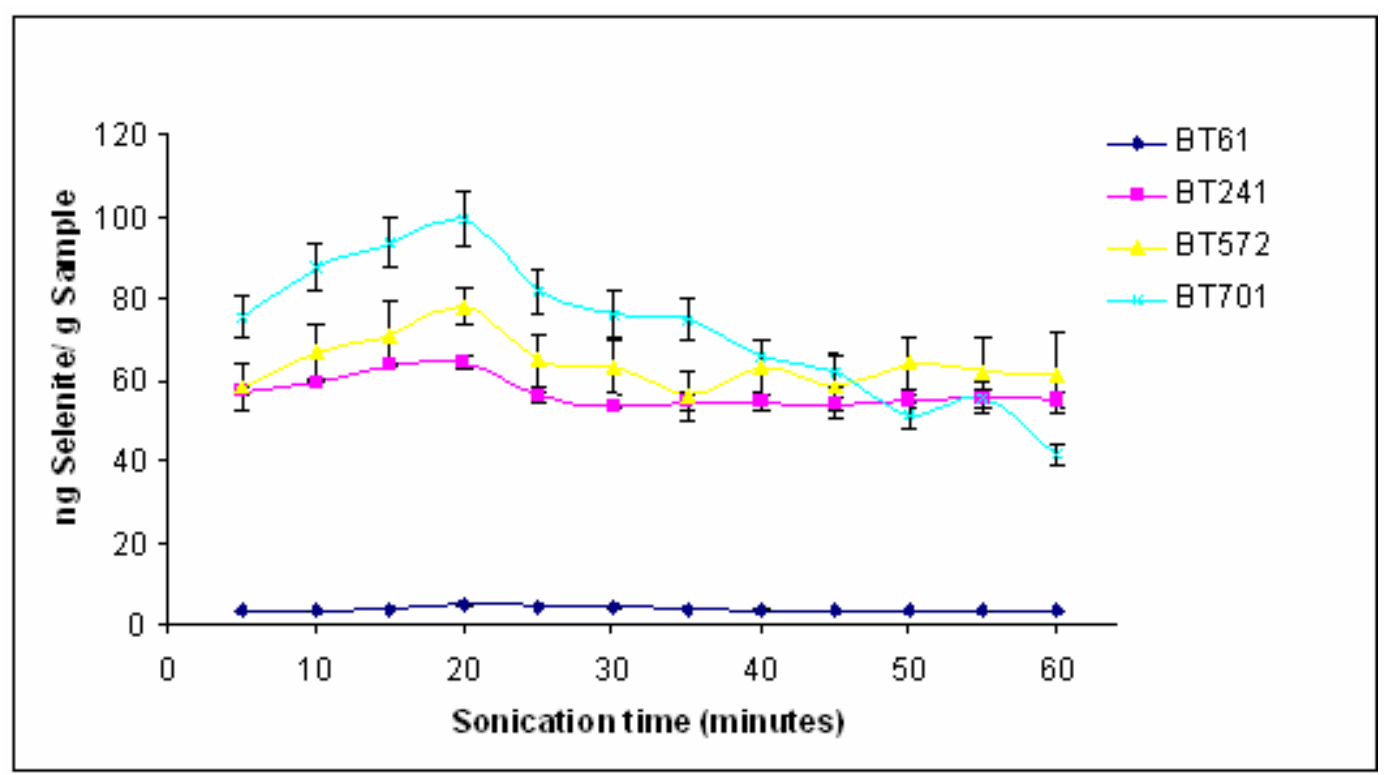

Figure 23: Selenium (IV) concentration released in batch sonicated extracts 


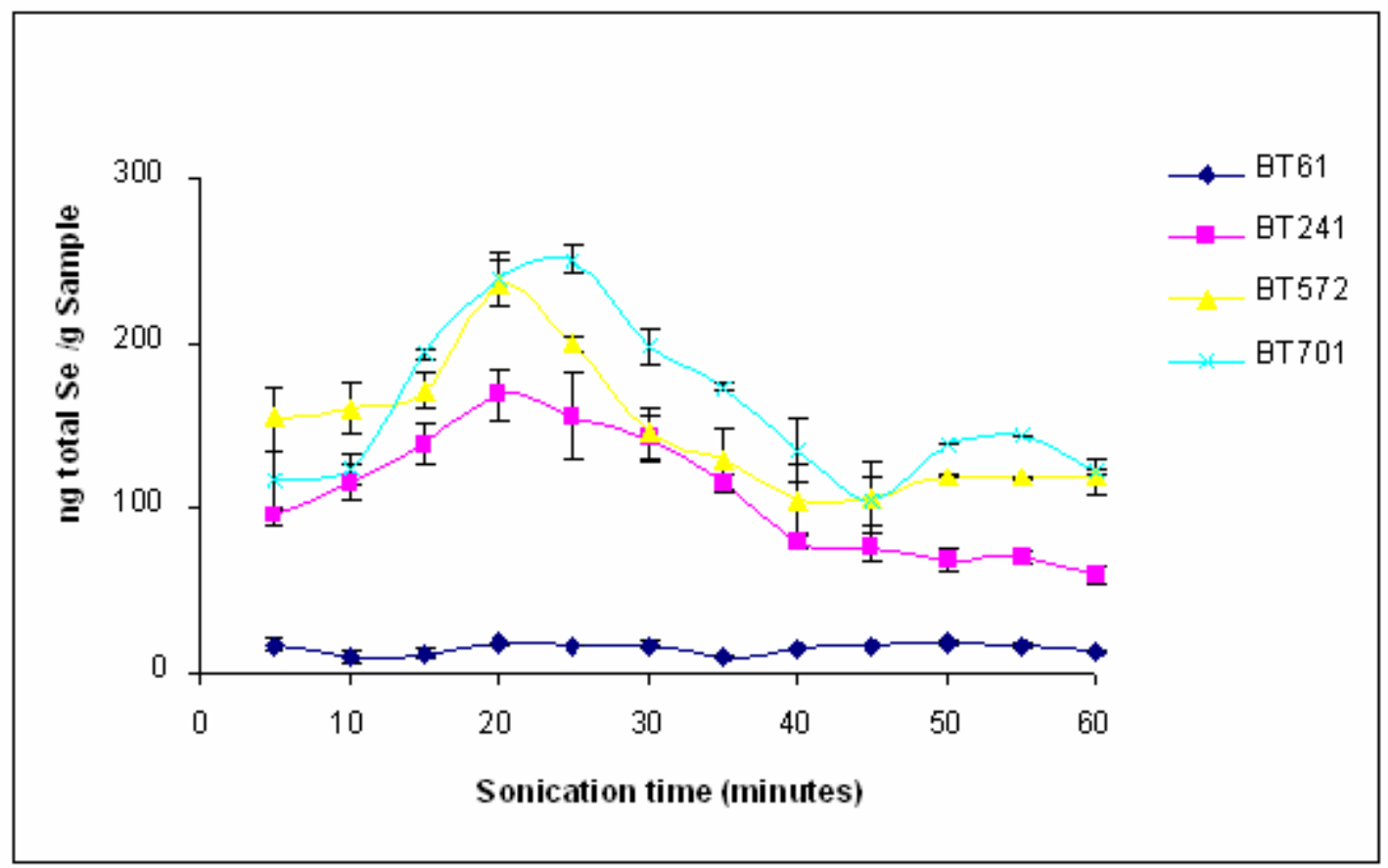

Figure 24: Total selenium concentration released in batch sonicated extracts 


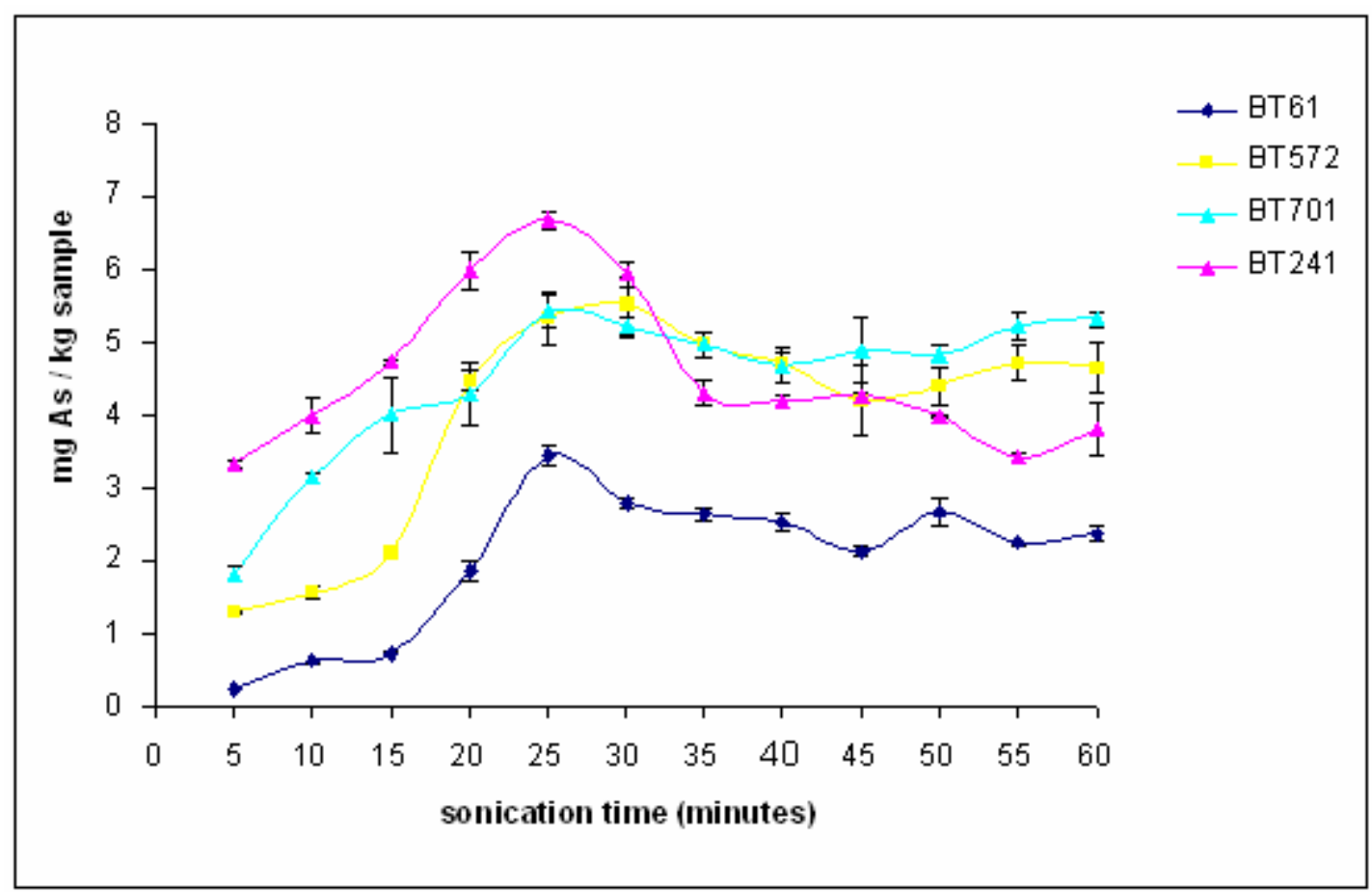

Figure 25: Total arsenic released in batch sonicated extracts 


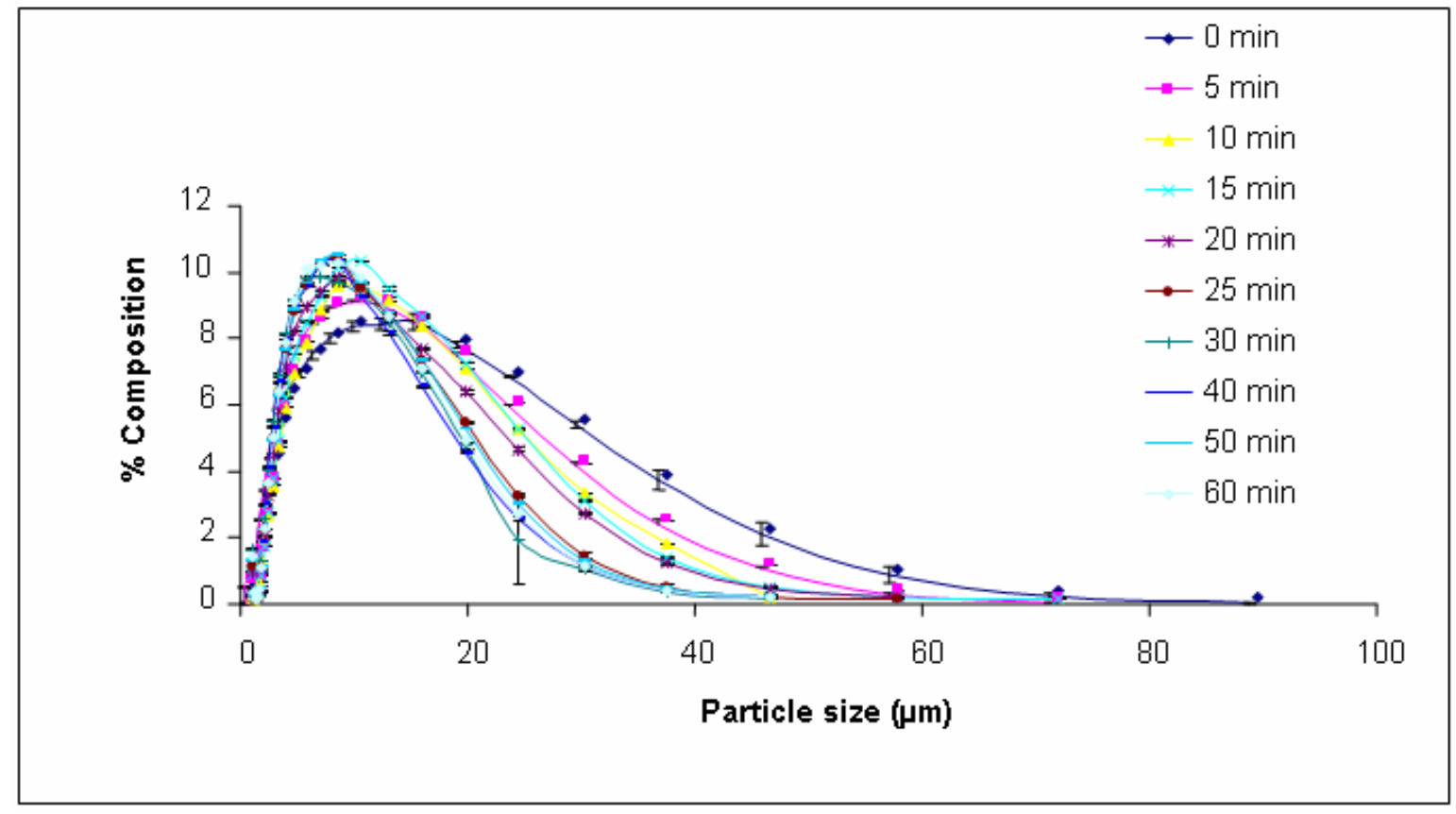

Figure 26: Particle size distributions as function of sonication time 


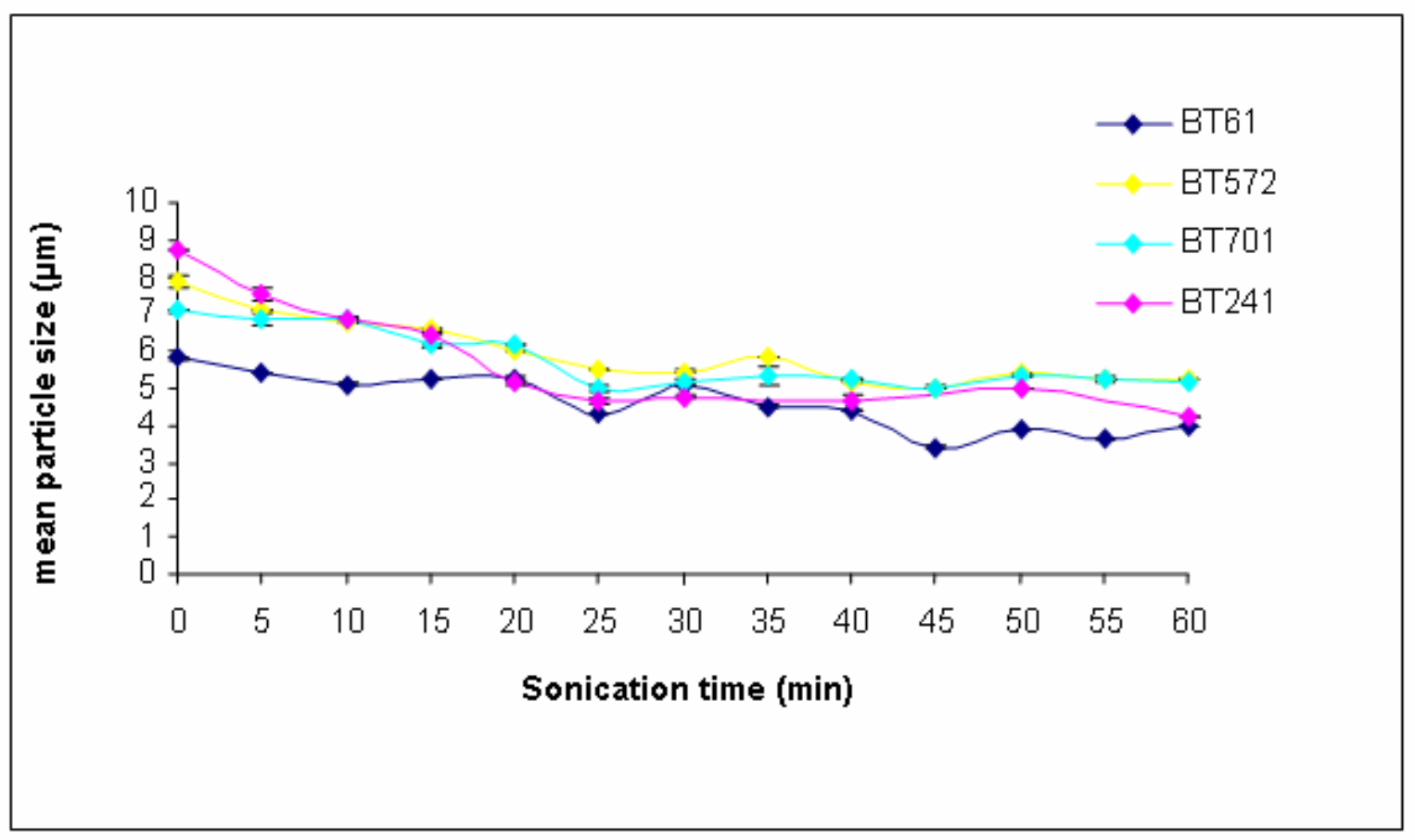

Figure 27: Variation of mean particle size with sonication time 
This observation can be attributed to that fact that high alkaline $\mathrm{pHs}$ in $\mathrm{NaOH}$ solutions have the capacity to dissolve polar organic molecules normally associated with dissolved organic matter like humic and fulvic acids that contain appreciable amounts of selenium. Total arsenic concentrations in the different ultrasonic extracts did not vary much and were all approximately $10 \%$ of the total available arsenic as obtained by microwave digestions (Figure 30).

It appears that not all selenium and arsenic present in rocks is immediately bioavailable. The loosely bound species consisting of those occupying the silicate octahedral interlayer spaces and those that are held by electrostatic forces are easily released into solution and constitute the environmentally significant fraction.

\section{Sequential extractions}

Results from the sequential extraction method are summarized in Figures 31-33 Elemental selenium was found to be below the detection limit of $0.5 \mathrm{ng} / \mathrm{mL}$ for all samples. No significant differences in concentrations were found between the $\mathrm{CrCl}_{2}$ treated and untreated residues. Hence it was concluded that there were no measurable diselenide concentrations in the rocks analyzed.

Total extracted selenium was found mainly in the water soluble, exchangeable, base soluble and the residual fractions. No significant concentration of selenium was found in the acid soluble fraction which suggests that selenium compounds in the core samples are not associated with carbonate-containing rock species such as siderite, calcium and magnesium carbonates. The $\mathrm{NaOH}$ soluble fraction in BT701 had the highest selenium concentrations compared to the residual fraction in all the clay samples (BT241, BT571 and BT701) as shown in Figure 32. This observation suggests that selenium in the BT701 
sample is closely associated with organic material and that has not yet been mineralized. BT 241 and BT 571 had total residual selenium concentrations that are higher than the $\mathrm{NaOH}$ fractions. Selenite was found to be largely associated with three fractions; water soluble, base soluble and residual. Approximately $10 \%$ of the available arsenic was released by the combined three extractants; water soluble, base soluble and acid soluble with $90 \%$ remaining in the residual matrix. Concentrations of arsenic in the phosphate buffer extract were below the detection limit. This provides more evidence to suggest that selenium and arsenic occupy different sites in the rocks.

Although only $10 \%$ of the arsenic was extractable, the concentrations of arsenic found were almost three orders of magnitude greater than selenium concentrations as reported in Chapter 2. The acid soluble fraction contained substantial amounts of arsenic as shown in Figure 33, which suggests that some arsenic species are associated with carbonate containing rock constituents.

The distribution of selenium can be explained in terms of inner-sphere and outersphere bonding. The water soluble fraction was considered to contain outer-sphere bonded and the base soluble and the exchangeable fractions represent inner-sphere selenium and arsenic that are held more tightly to the rock particles by chemical bonding. It is likely that in both scenarios the selenium and arsenic are contained within the interstitial spaces between the octahedral and tetrahedral layers of the clay minerals in rocks and that selenium and arsenic species occupy different sites. 


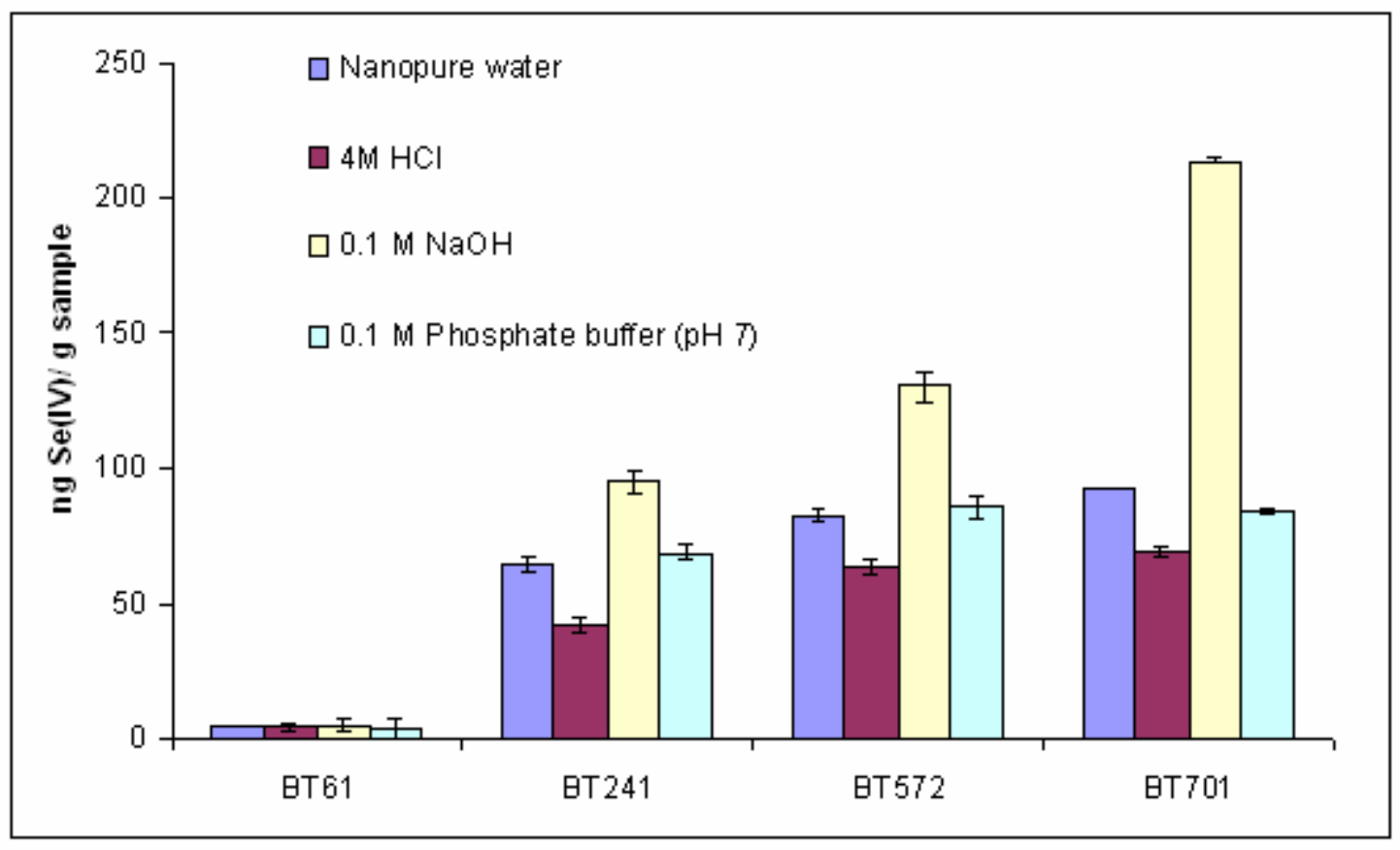

Figure 28: Selenite (ng/g) extracted after 20 minutes of sonication. 


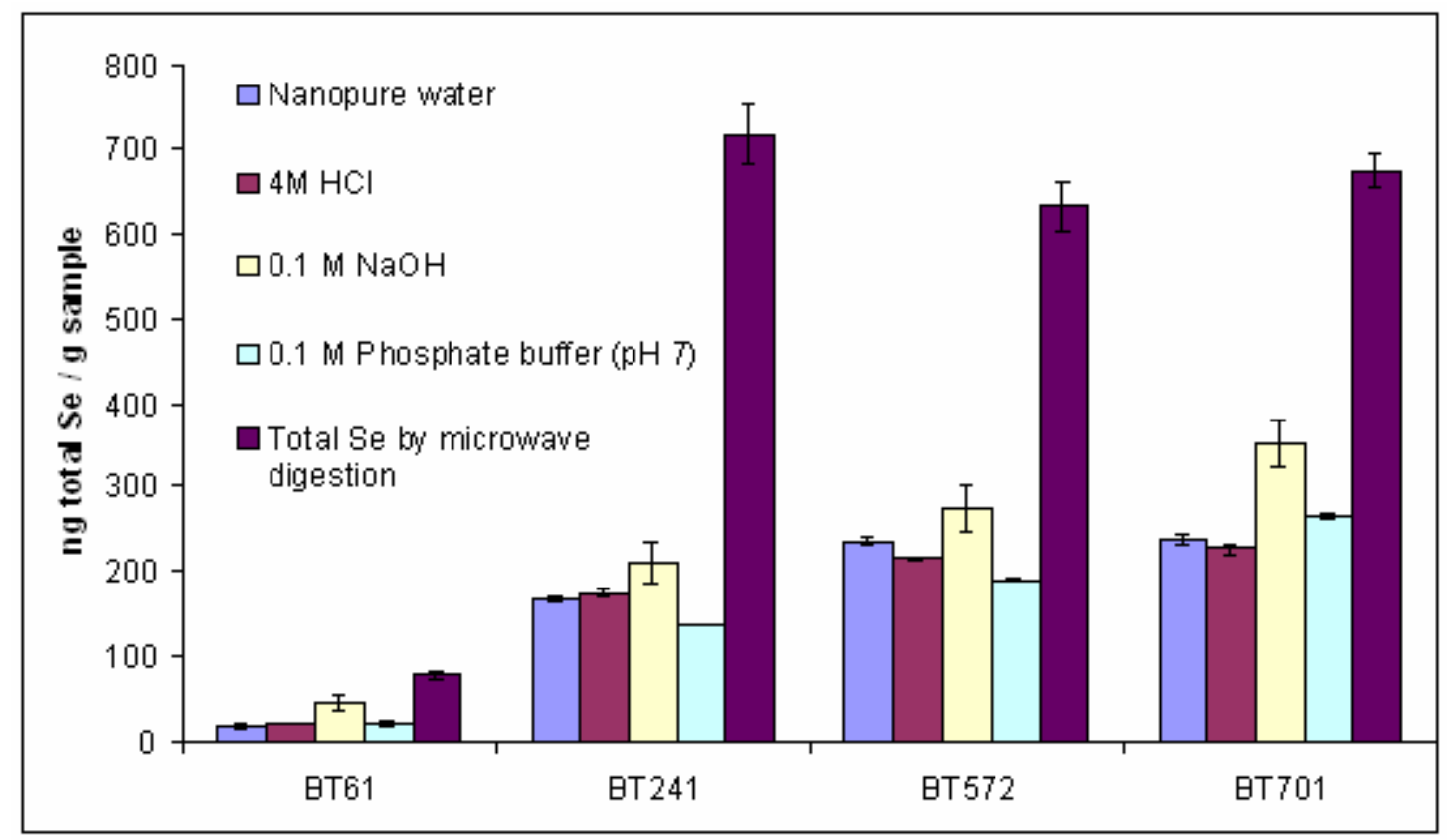

Figure 29: Total selenium extracted after 20 minutes of sonication. 


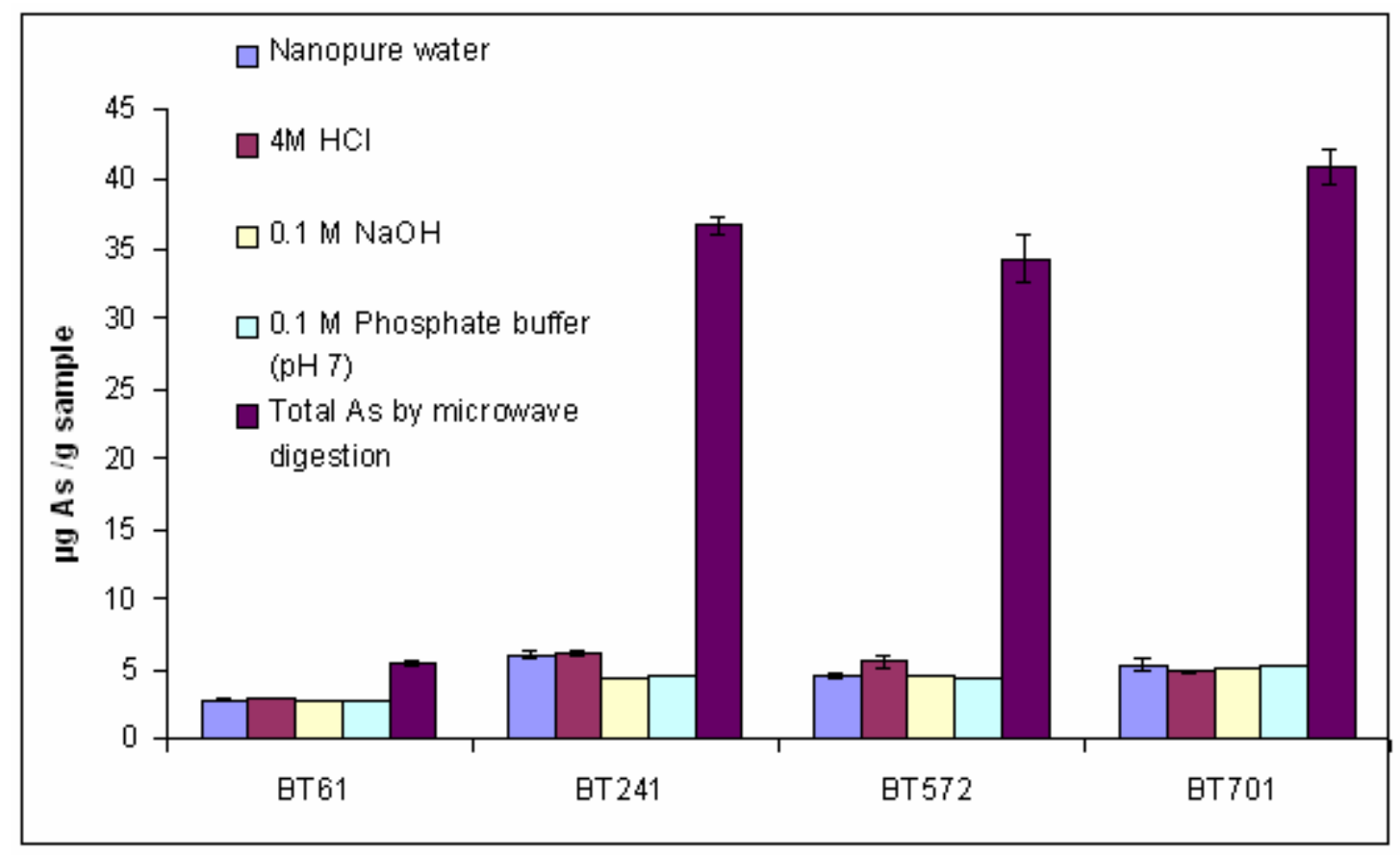

Figure 30: Total arsenic $(\mu \mathrm{g} / \mathrm{g})$ sample extracted after 20 minutes of sonication. 


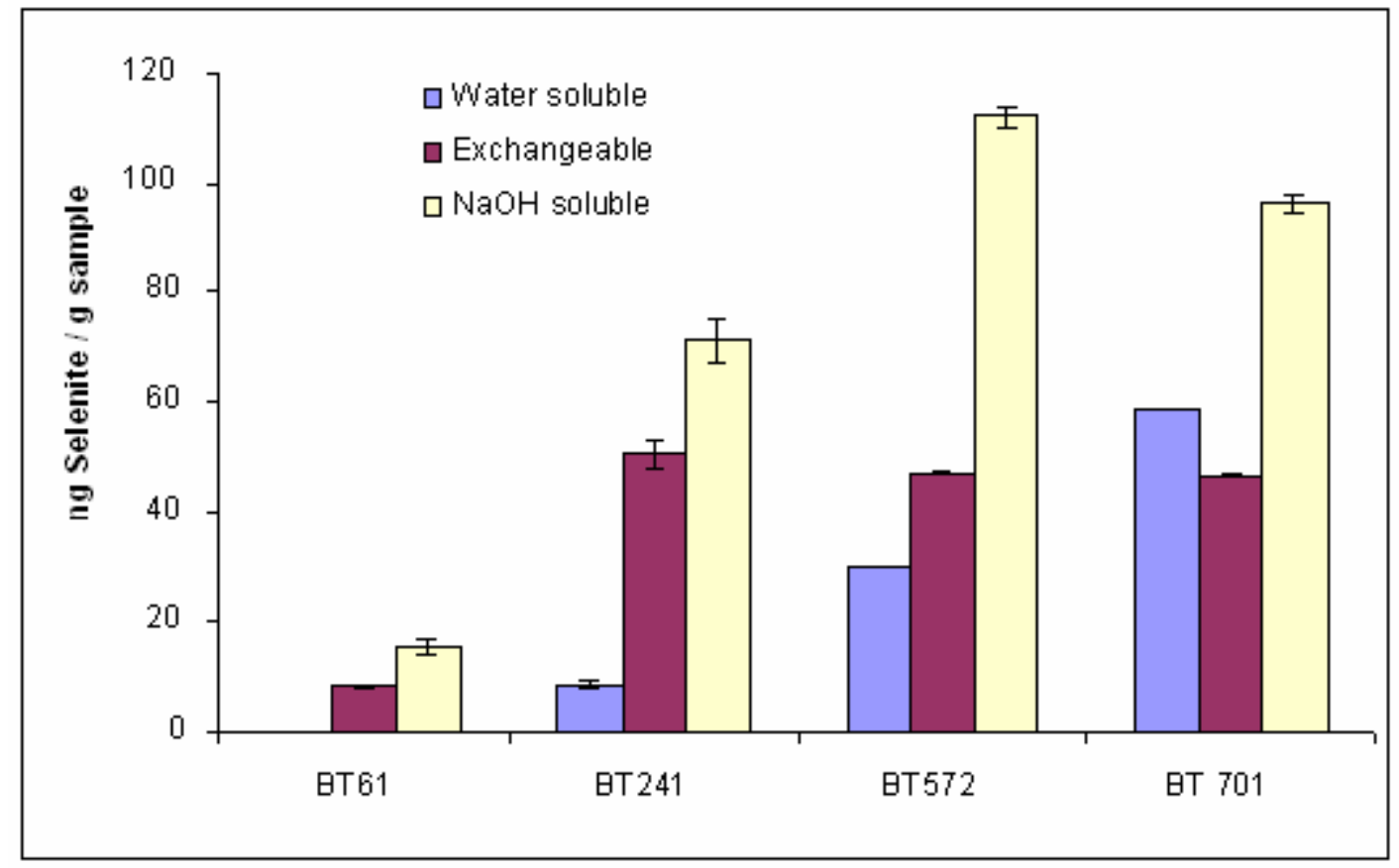

Figure 31: Sequential extraction of selenite in core samples 


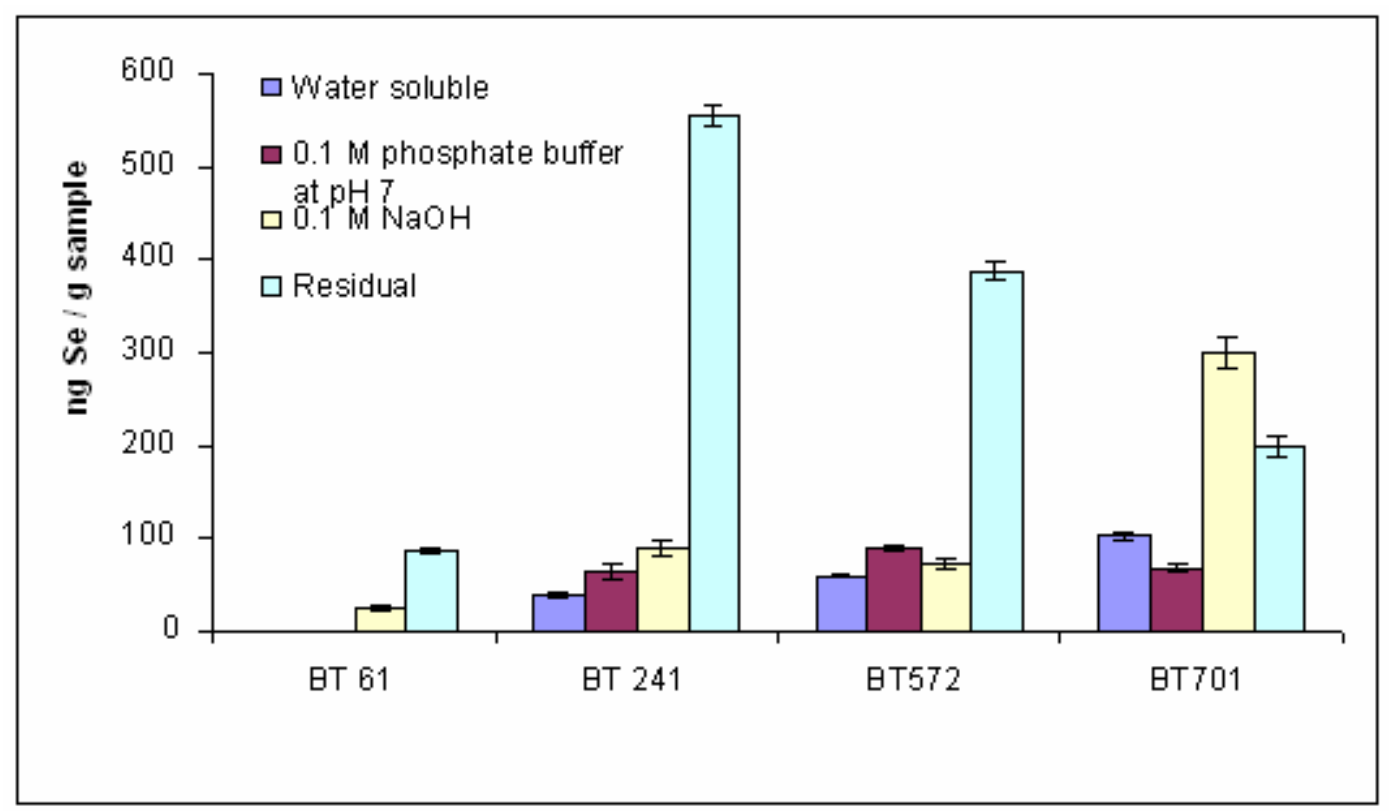

Figure 32: Sequential extraction of total selenium in core samples 


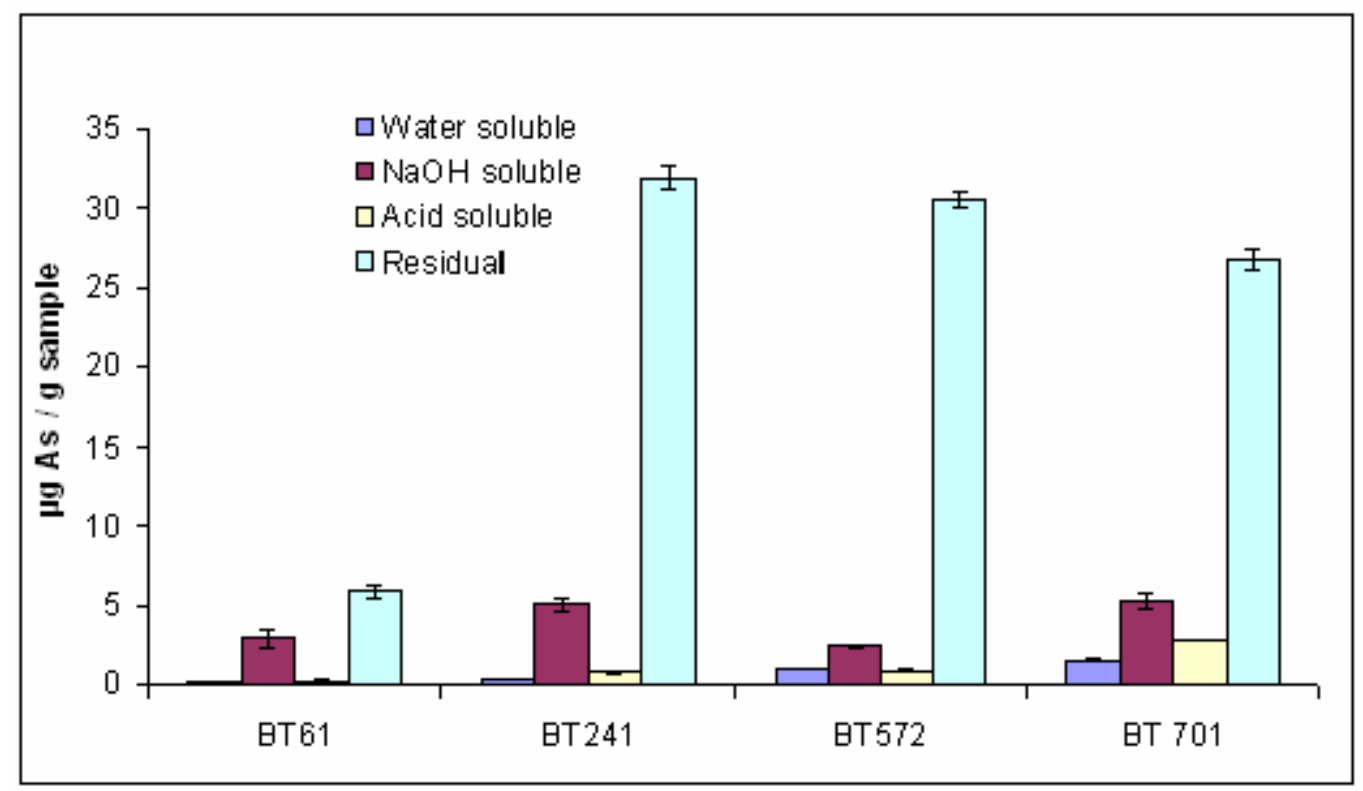

Figure 33: Sequential extraction of total arsenic in core samples 


\section{Comparison of bioavailable fractions determined with sequential and ultrasound extractions}

The comparison between the bioavailable fraction (water soluble + exchangeable + base soluble + acid soluble) and the 20 minutes sonicated extracts for selenite, total selenium and 25 minutes sonicated extracts for arsenic are summarized in Figures 34-36. By comparing the concentrations obtained by sonication to the bioavailable fraction from sequential extraction, it can be clearly seen that the concentrations obtained using the two methods are not significantly different with the exception of sample BT701 as shown in Figures 35 and 36 . The difference can be explained in terms of the contributions from the acid soluble fraction which was small for all the other samples. The acid soluble fractions could not be extracted by sonication because of the prevailing highly alkaline $\mathrm{pH}$ values. Further, the $\mathrm{pH}$ of MTR/VF associated water ranges from $6.5-9.0^{7}$ which are not acidic enough to decompose carbonate containing rock constituents therefore, this fraction is not of immediate environmental significance unless there are incidences of acidic drainages. It seems plausible that 20 minute sonication extraction and 25 minute sonication extractions can be used to estimate the bioavailable selenium and arsenic in the core samples. 


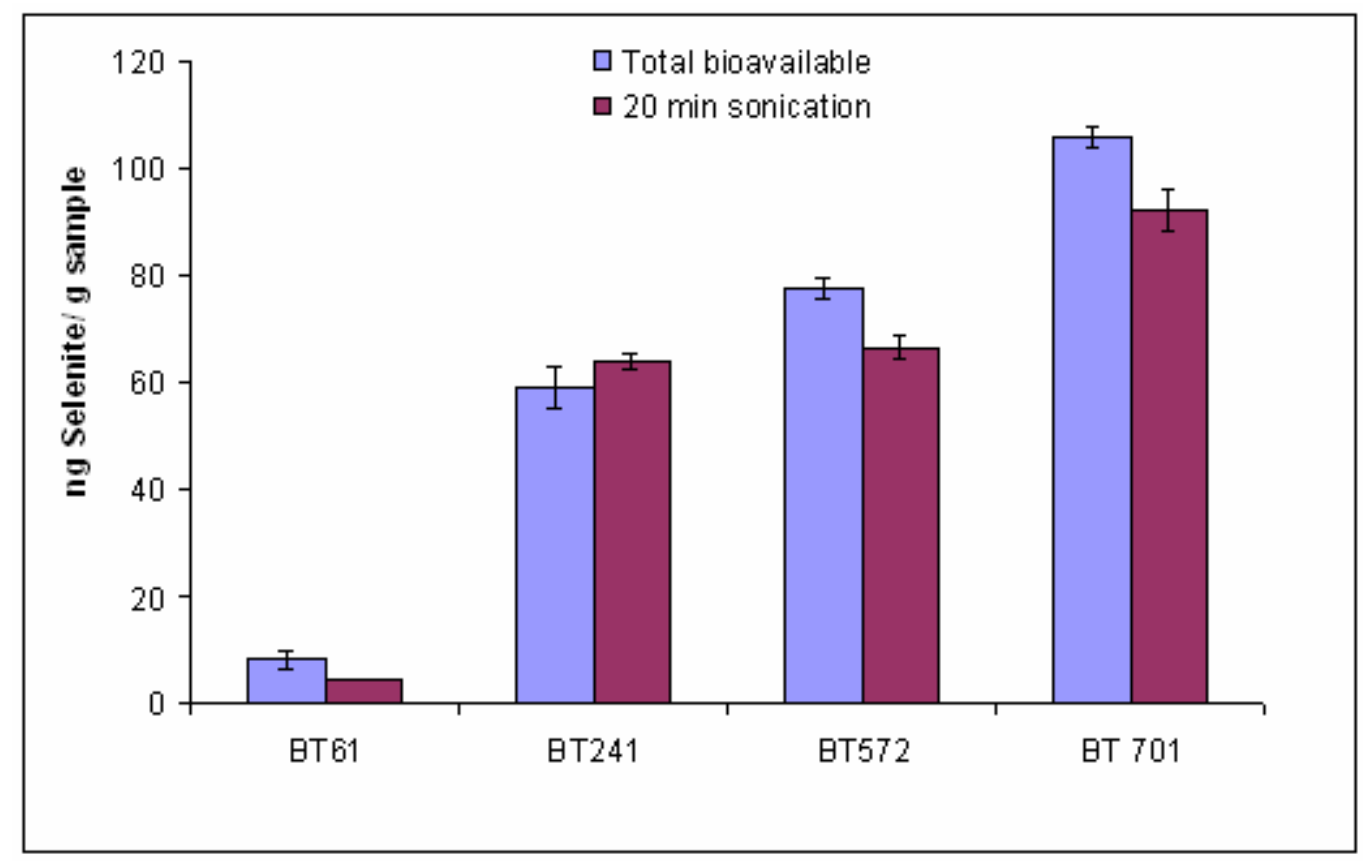

Figure 34: Comparison of bioavailable selenite with ultrasound extraction 


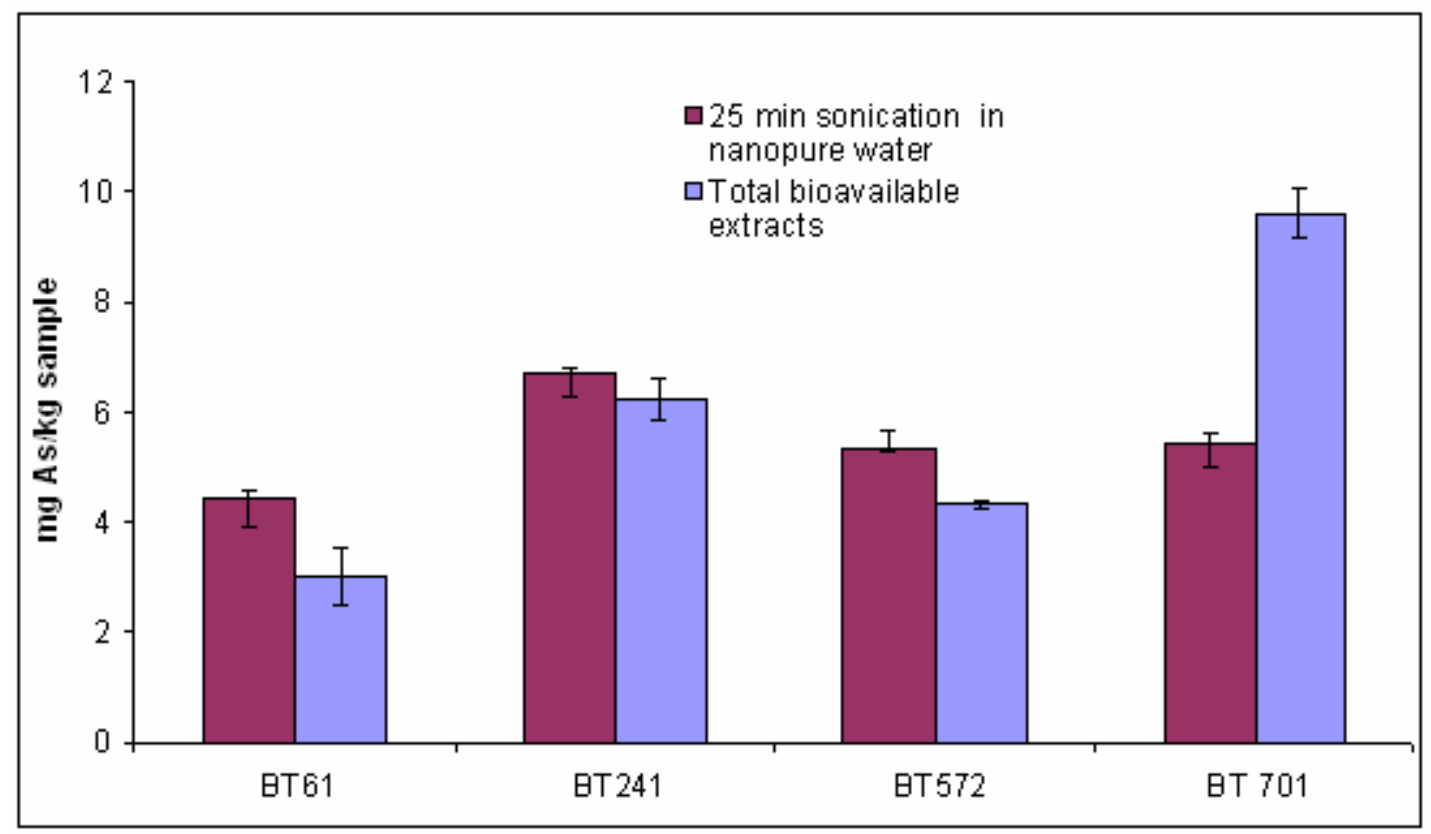

Figure 35: Comparison of bioavailable and total arsenic with ultrasound extraction 


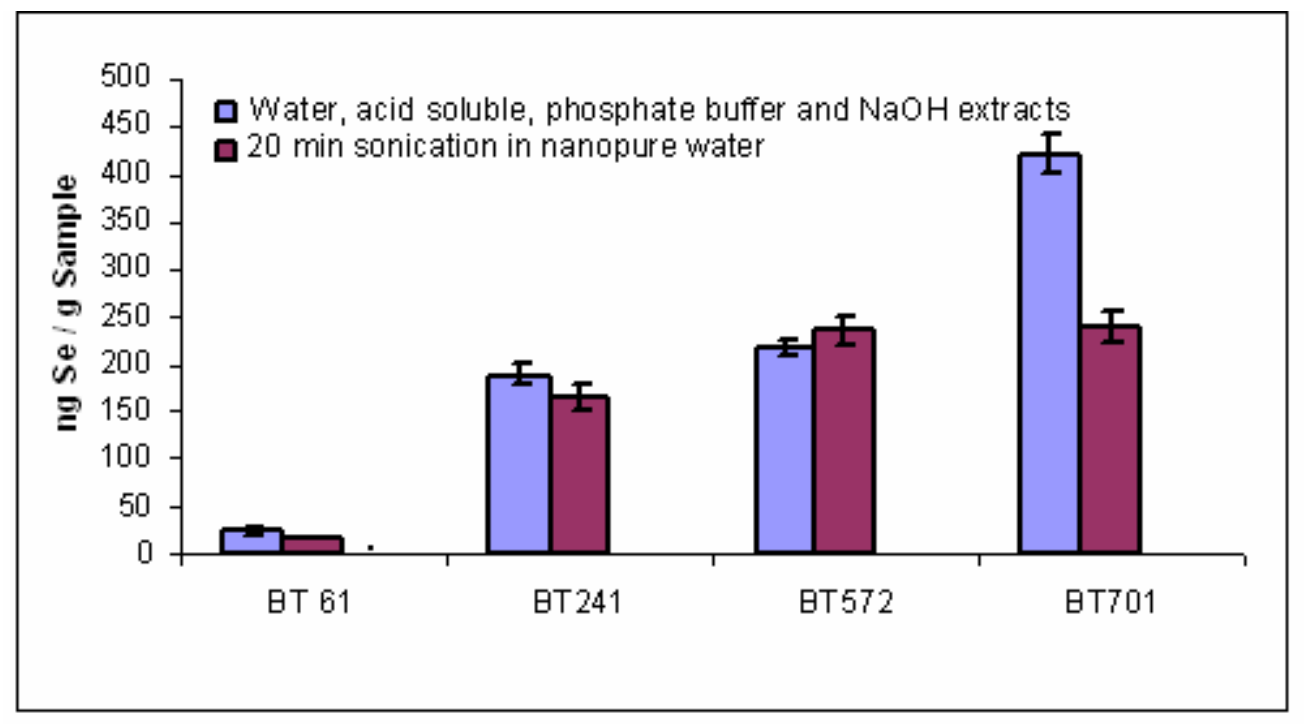

Figure 36: Comparison of bioavailable total selenium with ultrasound extraction 


\section{Summary}

Ultrasound extraction is a reliable method for the extraction of bioavailable selenium and arsenic from coal associated rocks. Nanopure water does not introduce anything foreign during extraction. The solution composition will reflect that of the rock sample matrix and create $\mathrm{pH}$ and redox environments that closely resemble natural aquatic systems at the solid /solution interface. Twenty minutes sonication and twenty-five minutes sonication in nanopure water at $200 \mathrm{~W} / \mathrm{cm}^{2}$ are the optimal conditions for the extraction of bioavailable arsenic and selenium from pulverized rock samples. 


\section{Chapter 4: Distribution of Selenium and Arsenic between Water and Sediment Samples}

\section{Introduction}

Weathered rock mineral particles, other inorganic materials and natural organic matter in stream and river beds react with selenium and arsenic that has been extracted from valley fills. The partitioning of arsenic and selenium between the sediment and water columns has been for a long time defined as a critical process that determines the extent of sequestration and remobilization at the solid-solution interface. ${ }^{108,109}$ Most of the clay minerals present on the earth's surface were formed as a result of weathering of silicate minerals, primarily feldspars, micas, pyroxenes and amphiboles. The hydration of feldspar in the presence of dissolved carbon dioxide results in the formation of several clays minerals that include illite, various 14 Á clays minerals, kaolinite and others. ${ }^{110-112}$ The continued hydration on stream beds will ultimately result in kaolinization, the formation of kaolinitic clays ${ }^{113}$, and therefore most stream and river beds contain appreciable amounts of kaolin. ${ }^{114}$ The kaolinization reaction can be presented chemically as follows:

$2 \mathbf{K A l S i}_{3} \mathbf{O}_{\mathbf{8}}(\mathrm{K}$-Feldspar $)+2 \mathrm{CO}_{2}+11 \mathrm{H}_{2} \mathrm{O}--->\mathbf{A l}_{2} \mathbf{S i}_{2} \mathbf{O}_{\mathbf{5}}(\mathbf{O H})_{4}($ Kaolinite $)+2 \mathrm{~K}^{+}+$ $4 \mathrm{H}_{4} \mathrm{SiO}_{4}+2 \mathrm{HCO}_{3}^{-}$

The kaolinite produced can participate in the adsorption/sorption ${ }^{115}$ and subsequent biogeochemical transformations of organic, inorganic molecules and ions in the sediments. Kaolinite therefore plays a critical role on the loading and releases of metals and nonmetals on river beds. ${ }^{116}$ In order to model the chemistry at the solid solution interface, selenium and arsenic standards solutions were mixed with kaolinite, silica gel and humic acid to determine the sorption and redox properties. Silica gel was included in the adsorption 
experiments because some sandy sediments have more silica than kaolinitic clays. Given the toxicity associated with arsenic and selenium and the desire to understand the mechanisms involved in their releases from sediments, experiments were designed as follows:

(1) Analysis of river water and sediments collected from the sites previously reported to have high aqueous concentrations of Se by the USEPA in 2000;

(2) Suggest reasons for undetectable arsenic concentrations in the water even though kinetic studies in Chapter 2 showed that concentrations of arsenic released from rocks were higher than selenium.

(3) To estimate the total bioavailable fractions of arsenic and selenium in sediment using ultrasound extractions.

(4) To model the sediment-solution interactions at riverbeds using kaolin, silica and humic acids with selenium and arsenic standards.

\section{Experimental}

\section{Sediments and water samples}

Three water and three sediments samples collected by WVGES in 2001 from the Mud River watershed (MT 15 and 18) and Spruce Fork watershed (MT 34B) were found to have high aqueous concentrations of selenium.

\section{Pretreatment of kaolin and silica gel}

Silica gel (20 g, Universal scientific Inc.) was soaked for 24 hours in $50 \mathrm{~mL}$ of $2 \mathrm{M}$ $\mathrm{HNO}_{3}$ followed by 24 hours in $50 \mathrm{~mL}$ of $2 \mathrm{M} \mathrm{NaOH}$. It was washed with nanopure water until the filtrate was neutral to a litmus paper, followed by $70 \%$ ethanol and dried at $105^{\circ} \mathrm{C}$ for four hours before use. Kaolin (20 g, Fisher Scientific) was treated the same as for silica 
gel followed by washing with nanopure water until the filtrate did not form any precipitate with $1 \mathrm{M} \mathrm{AgNO}$.

\section{Sorption of selenium and arsenic compounds on kaolin and silica gel}

Slurries containing of $50 \mathrm{~mL}$ of nanopure water and $1 \mathrm{~g}$ of each of treated silica and kaolin were prepared separately. The water-kaolin and water-silica mixtures were allowed to equilibrate for 24 hours at room temperature followed by $\mathrm{pH}$ (2-8) adjustment using dilute $\mathrm{NaOH}$ and $\mathrm{HNO}_{3}$. The ionic strength was adjusted to $2 \mathrm{mM}$ (as $\mathrm{NaCl}$ ) with $1 \mathrm{M}$ $\mathrm{NaNO}_{3}$ using a conductivity meter (HACH sensION5). Standard solutions of Se (IV), Se (VI), As (III) and As (V) were individually added into separate containers with treated kaolin and silica to result in $50 \mathrm{ng} / \mathrm{mL}$ concentration of each standard. The mixtures were allowed to equilibrate for 24 hours at $24 \pm 1{ }^{\circ} \mathrm{C}$ followed by centrifugation at $3400 \mathrm{rpm}$ for twenty minutes. The supernatant solution was analysed for unsorbed ions using graphite furnace atomic absorption spectrometry.

\section{Reduction of selenate on kaolin}

In sorption/redox kinetics experiments, $250 \mu \mathrm{L}$ of $10 \mathrm{ppm}$ Se (IV) and Se (VI) were added to mixtures containing $1 \mathrm{~g}$ treated kaolin in $50 \mathrm{ml}$ of nanopure water and $50 \mathrm{ml}$ of 4.4 mg/L Suwannee River humic acid (HA) (International Humic Substance Society). All standards and mixtures were initially purged with $\mathrm{N}_{2}$ gas to remove any interfering oxygen. The concentration of selenium $(50 \mathrm{ng} / \mathrm{ml})$ and $\mathrm{HA}(4.4 \mathrm{mg} / \mathrm{L})$ were chosen because these were found to be the highest concentrations of total selenium and total organic carbon in southern West Virginia streams. ${ }^{7}$ The mixtures were equilibrated for 24 hours followed by adjusting the $\mathrm{pH}(4$ and 7$)$ and ionic strength $(2 \mathrm{mM}$ as $\mathrm{NaCl})$ before adding selenium standards. Experiments were run in triplicate with an accompanying blank for each. 
Se (IV) and Se (VI) concentrations were monitored as a function of time. Aliquots of $10 \mathrm{ml}$ were taken for each replicate under a $\mathrm{N}_{2}$ atmosphere and then centrifuged at 3400 $\mathrm{x} g$ for 20 minutes to remove suspended particles. The supernatant solutions were analysed to determine the concentrations of unsorbed species by graphite furnace and hydride generation atomic absorption spectrometry. HA was analysed by absorbance at $300 \mathrm{~nm}$. All experiments were carried out at $24 \pm 1^{\circ} \mathrm{C}$.

\section{Results and discussion}

The water samples collected in 2007 from the Mud River watershed (MT 15 and MT 18) had lower concentrations of selenium compared to the Spruce fork watershed (MT34B) as shown in Table 12. Selenium concentrations at MT 18 and MT 34B sampling locations continue to violate the WV stream standard $(5 \mathrm{ng} / \mathrm{mL})$. Selenium concentration at MT 15 and MT 18 did decrease from the values obtained in the 2001 study ${ }^{7}$ but remained almost constant at MT 34B. The weathering of mining waste generated from an active mine near MT 34B seems to be continuously supplying selenium to the sampling point. Since no arsenic was found in the stream water, it appears that it is removed from the aqueous phase and adsorbed/sorbed by sediments.

The highest amounts of total arsenic $(14.6 \mu \mathrm{g} / \mathrm{g})$ and selenium $(10.7 \mu \mathrm{g} / \mathrm{g})$ in the sediment samples were found at MT34B as shown in Table 13. It follows that there should be substantial amounts of selenium and arsenic released from the MT 34B sediment using ultrasound energy and sequential extraction techniques. The total amount of selenium (577 $.0 \mathrm{ng} / \mathrm{g})$ released via 20 minutes sonication is approximately equal to the selenite $(545.8$ 


\begin{tabular}{|l|l|l|l|}
\cline { 2 - 4 } \multicolumn{1}{c|}{} & $\begin{array}{l}\text { MT 15 } \\
\text { ng/mL Se }\end{array}$ & $\begin{array}{l}\text { MT 18 } \\
\text { ng/mL Se }\end{array}$ & $\begin{array}{l}\text { MT 34B } \\
\text { ng/mL Se }\end{array}$ \\
\hline This work (2007) & $2.7 \pm 0.7$ & $14.9 \pm 0.9$ & $21 \pm 2$ \\
\hline EPA (2000) & 12.1 & 36.8 & 22.7 \\
\hline
\end{tabular}

Table 12: Comparison of selenium concentrations in water samples. The arsenic concentrations in all the samples were below the detection limit in both years. 


\begin{tabular}{|l|l|l|l|l|l|}
\hline Sample & $\begin{array}{l}\text { Total Se by } \\
\text { microwave } \\
\text { digestion } \\
\mu \mathrm{g} / \mathrm{g}\end{array}$ & $\begin{array}{l}\text { Total As by } \\
\text { microwave } \\
\text { digestion } \\
\mu \mathrm{g} / \mathrm{g}\end{array}$ & $\begin{array}{l}20 \text { minutes } \\
\text { sonication } \\
\text { total Se } \\
\mathrm{ng} / \mathrm{g}\end{array}$ & $\begin{array}{l}20 \text { minutes } \\
\text { sonication } \\
\mathrm{As} \\
\mathrm{ng} / \mathrm{g}\end{array}$ & $\begin{array}{l}20 \text { minutes } \\
\text { sonication } \\
\text { Se(IV) } \\
\mathrm{ng} / \mathrm{g}\end{array}$ \\
\hline MT 15 & $0.75 \pm 0.08$ & $14 \pm 1$ & $65 \pm 3$ & $\mathrm{ND}$ & $\mathrm{ND}$ \\
\hline MT18 & $0.62 \pm 0.03$ & $10.0 \pm 0.6$ & $41 \pm 3$ & $\mathrm{ND}$ & $\mathrm{ND}$ \\
\hline MT34 B & $10.7 \pm 0.5$ & $14.6 \pm 0.5$ & $580 \pm 10$ & $950 \pm 26$ & $546 \pm 1$ \\
\hline
\end{tabular}

Table 13: Comparison of total and ultrasound extractable arsenic and selenium in sediment samples. 
$\mathrm{ng} / \mathrm{g})$ concentration in the same extracts $(\mathrm{P} \leq 0.01, \mathrm{n}=9)$. Selenium and arsenic concentrations in the MT15 and MT18 sonicated sediment extracts were below detection $\mathrm{ng} / \mathrm{g}$ ) concentration in the same extracts. Selenium and arsenic concentrations in the MT15 and MT18 sonicated sediment extracts were below detection limits. Furthermore, MT15 and MT18 sample had low amounts of total selenium $0.75 \mu \mathrm{g} / \mathrm{g}$ and $0.62 \mu \mathrm{g} / \mathrm{g}$, respectively. The total arsenic concentration in MT34 B sediments was $30 \%$ and $5 \%$ higher than MT18 and MT15 sediments, respectively.

\section{Sequential extraction of selenite in sediments}

MT 34B had the highest concentration of total extractable selenite as shown in Figure 37. Appreciable amounts of selenite were found in the MT 34B water $(113.0 \mathrm{ng} / \mathrm{g})$, phosphate buffer (391.2 ng/g) and acetic acid (113.0 ng/g) extracts. Selenite concentrations in water and phosphate buffer extracts for MT 15 and MT 18 were below the detection limit. The $\mathrm{NaOH}$ fraction had the highest amounts of extractable selenite species in all three sediment samples with the MT 34B having the highest concentration of $6.499 \mu \mathrm{g} / \mathrm{g}$, which is approximately three orders of magnitude greater than the combined selenite in water, phosphate buffer and acetic acid extracts.

\section{Sequential extraction of total selenium in sediments}

Extracted total selenium concentrations shown in Figure 38 followed a trend similar to the one observed for the selenite, however significant total selenium concentrations were found in MT15 (24.21 ng/g in water and $28.48 \mathrm{ng} / \mathrm{g}$ in phosphate buffer) and MT 18 (32.41 $\mathrm{ng} / \mathrm{g}$ in water and $12.69 \mathrm{ng} / \mathrm{g}$ phosphate buffer). The highest concentrations were observed in the MT 34B water (257.4 ng/g), phosphate buffer (399.6 ng/g) and $\mathrm{NaOH}(9.625 \mu \mathrm{g} / \mathrm{g})$ extracts. Selenium concentration in the $\mathrm{NaOH}$ extract was found to be more than 1000 


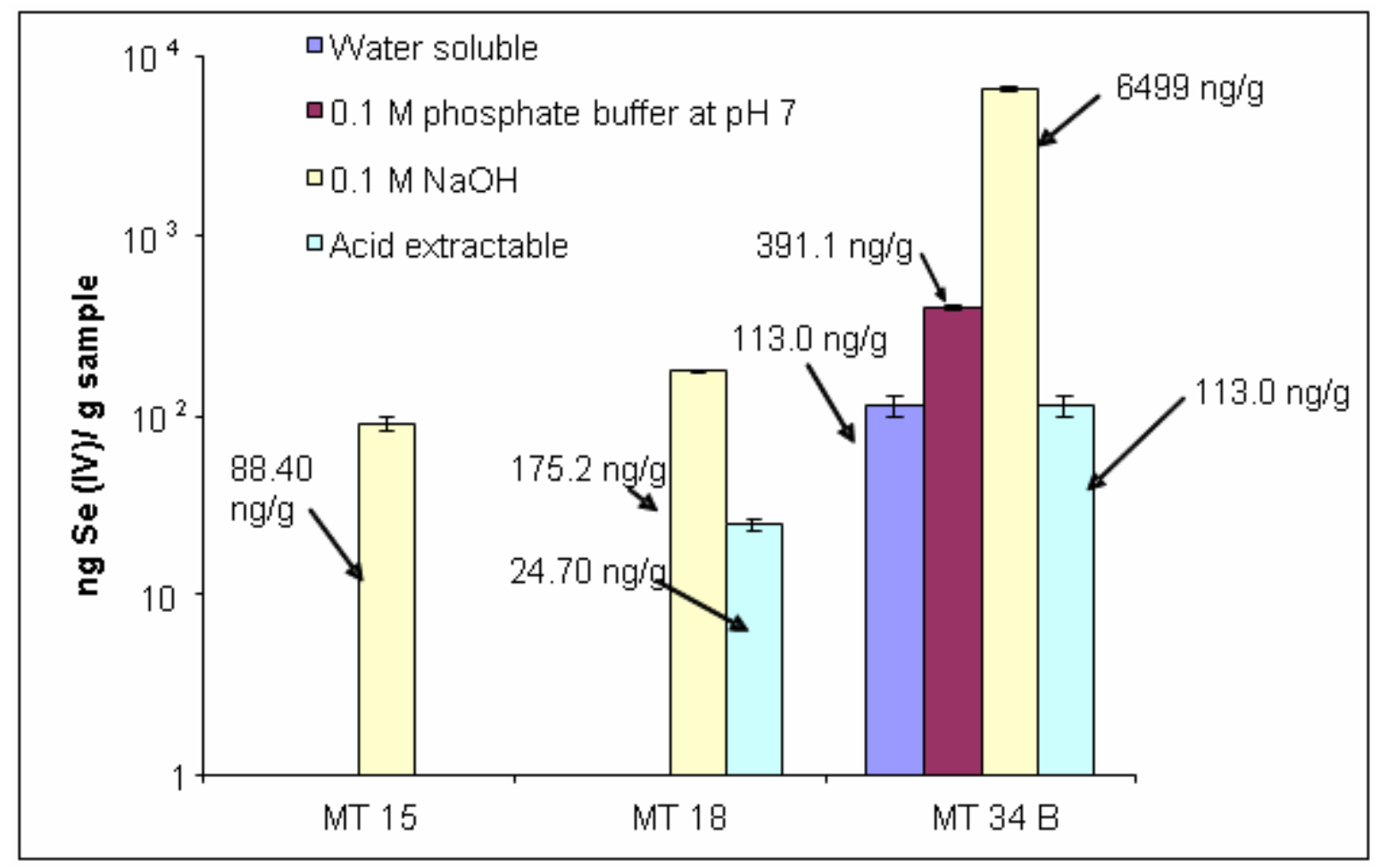

Figure 37: Sequential extraction of selenite from sediments on a logarithmic scale (with averaged concentration results). 


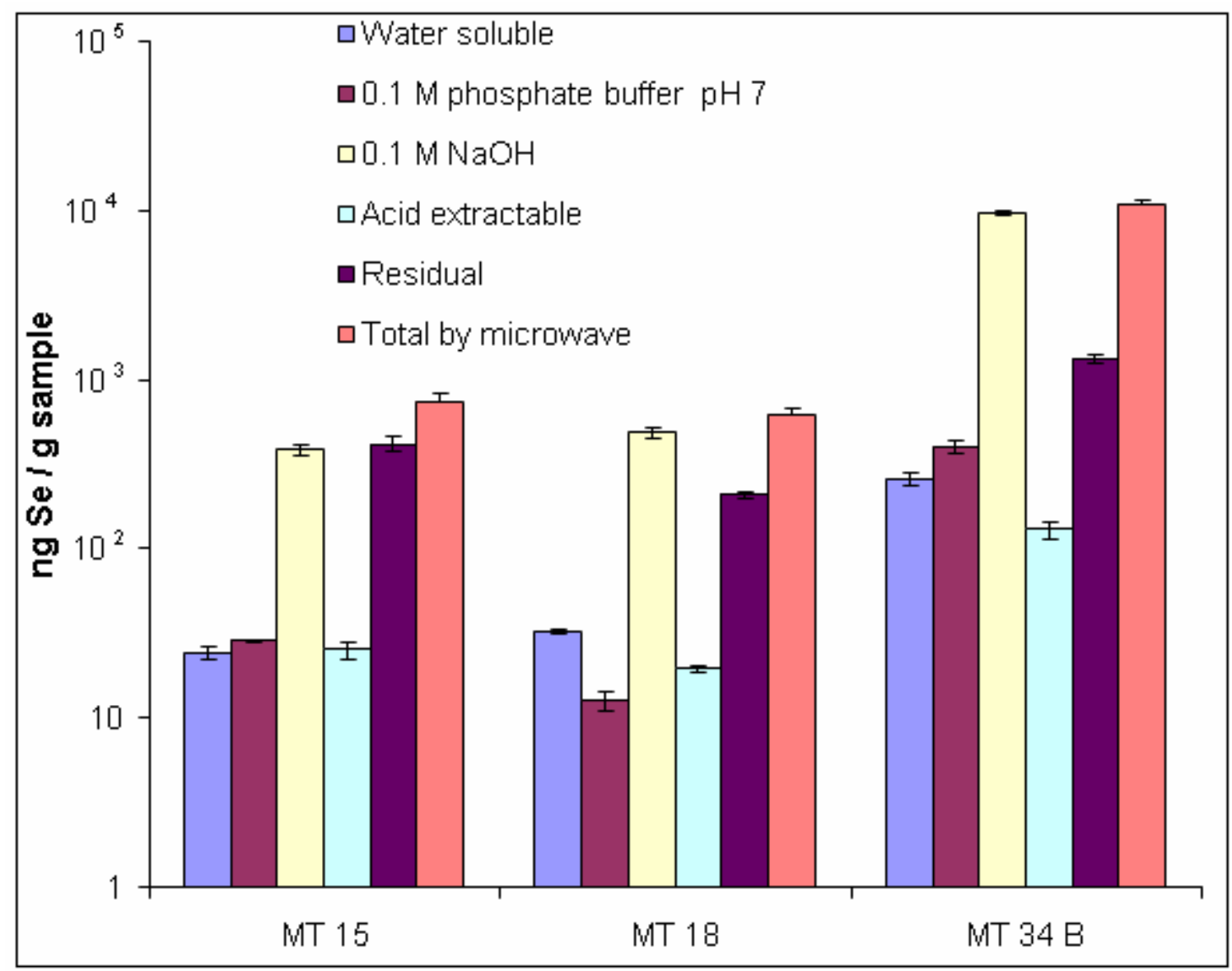

Figure 38: Sequential extraction of total selenium from sediments on a logarithmic scale 


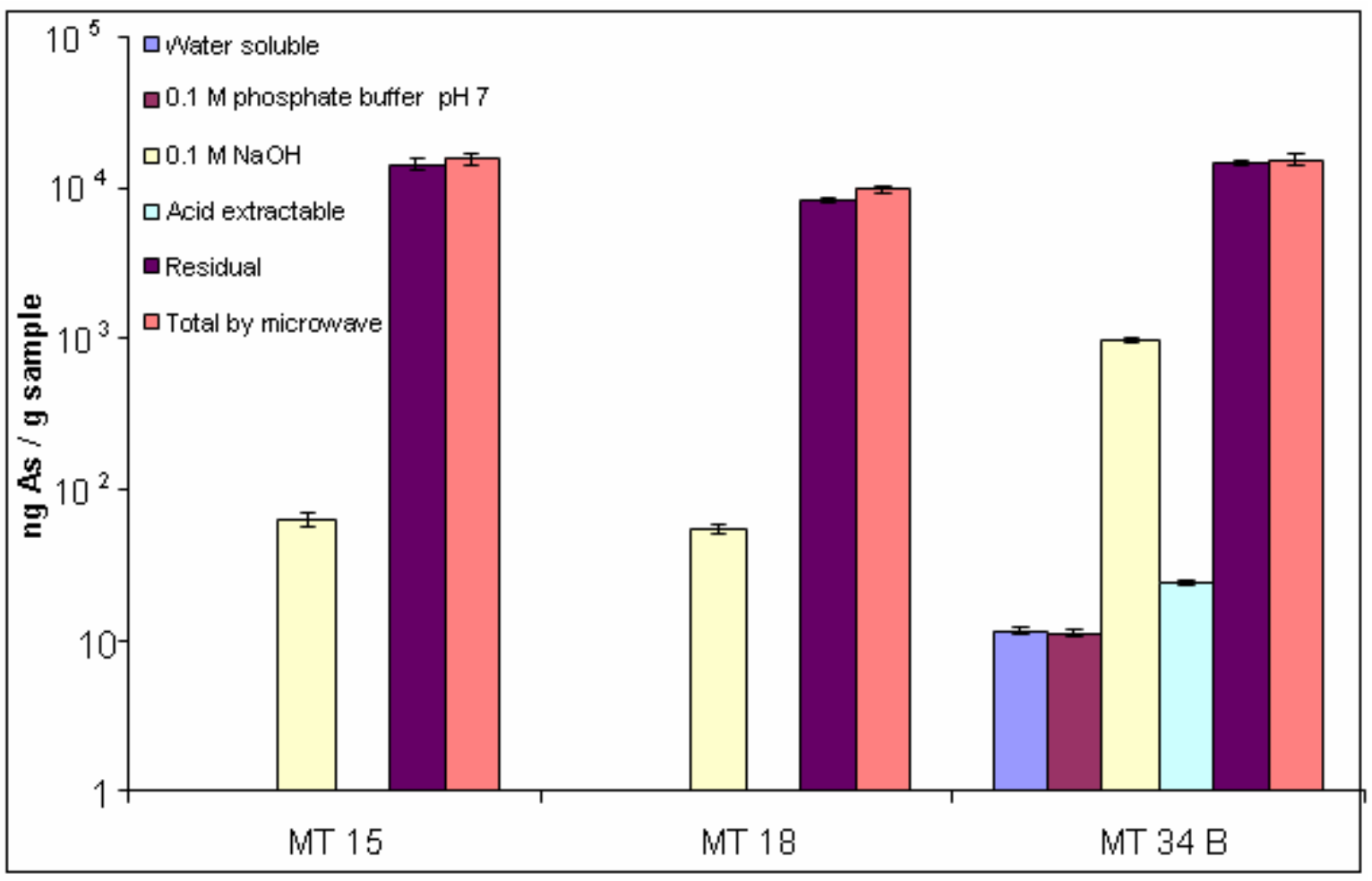

Figure 39: Sequential extraction of arsenic from sediments on a logarithmic scale. 


\begin{tabular}{|c|c|c|c|c|}
\hline \multirow{2}{*}{$\begin{array}{l}\text { Sample } \\
\text { number }\end{array}$} & \multicolumn{2}{|c|}{ Water samples } & \multicolumn{2}{|c|}{ Sediment samples } \\
\hline & $\begin{array}{l}\mathrm{ng} / \mathrm{mL} \\
\text { Selenium }\end{array}$ & $\begin{array}{l}\mathrm{ng} / \mathrm{mL} \\
\text { Arsenic }\end{array}$ & $\begin{array}{l}\mathrm{ng} / \mathrm{g} \\
\text { Selenium }\end{array}$ & $\mu \mathrm{g} / \mathrm{g}$ Arsenic \\
\hline 1 & N.D. & N.D. & $184 \pm 7$ & $14.2 \pm 0.6$ \\
\hline 2 & N.D. & N.D. & $102 \pm 15$ & $11.1 \pm 0.5$ \\
\hline 3 & N.D. & N.D. & $168 \pm 4$ & $10.4 \pm 0.3$ \\
\hline 4 & N.D. & N.D. & $60 \pm 4$ & $7.7 \pm 0.2$ \\
\hline 5 & N.D. & N.D. & $149 \pm 10$ & $14.2 \pm 0.3$ \\
\hline 6 & N.D. & N.D. & $205 \pm 16$ & $14.1 \pm 0.8$ \\
\hline
\end{tabular}

Table 14. Concentration of arsenic and selenium in background water and sediment samples. (N.D. $=$ not detected or $<0.5 \mathrm{ng} / \mathrm{mL}$ ) 
times the combined concentration of water and phosphate buffer in the MT 34 B sediment extracts. Since the $\mathrm{NaOH}$ extract had highest concentration of selenium, it seems likely that selenium must be closely associated with organic molecules. ${ }^{117}$ High prevalence of selenite compared to selenate also suggests that sediments offer reducing conditions for the reduction of selenium species into selenites.

\section{Sequential extraction of total arsenic in sediments}

The concentrations of sequentially extracted arsenic are shown in Figure 39. MT 34B had the highest extractable arsenic, and most of it was in the $\mathrm{NaOH}$ fraction. Water and phosphate buffer extracts of MT 15 and MT 18 had undetectable amounts of arsenic, while the MT 34B had $11.63 \mathrm{ng} / \mathrm{g}$ and $11.10 \mathrm{ng} / \mathrm{g}$ extracted in water and phosphate buffer, respectively. The combined concentration of the two extracts is approximately 1000 times less than the total sediment concentration $14.6 \pm 0.5 \mu \mathrm{g} / \mathrm{g}$.

\section{Background samples}

All background water samples had both arsenic and selenium concentration below the limit of detection $(0.5 \mathrm{ng} / \mathrm{mL})$. Table 14 shows that background sediment samples had lower concentrations of selenium compared to MT 15, MT 18 and MT34 B (Figures 38). Total selenium concentrations were generally 3-10 times lower than concentrations found at MT15, MT18 and MT34 B suggesting a contribution from valley fills.

Total arsenic concentrations in the background samples ranged from 7.7 to 15.17 $\mu \mathrm{g} / \mathrm{g}$. Such a wide variance in arsenic concentrations (approximately $50 \%$ ), could have resulted from different lithologies surrounding the selected sampling locations that contain different amounts of arsenic species. 


\section{Sorption of arsenic and selenium on kaolin and silica gel}

Results from the silica gel adsorption studies showed that $\mathrm{SeO}_{3}{ }^{-2}, \mathrm{SeO}_{4}{ }^{-2}, \mathrm{AsO}_{3}{ }^{-2}$, and $\mathrm{AsO}_{4}{ }^{-2}$ species have low affinities at $\mathrm{pH}$ values ranging from 2-8 except for $\mathrm{AsO}_{4}{ }^{-2}$ which showed $30 \%$ adsorbed at $\mathrm{pH} 4$. The fraction adsorbed by kaolin versus $\mathrm{pH}$ for arsenate, arsenite, selenate and selenite is shown in Figure 40. Maximum sorption for all species was around $80 \%$ but occurred at different $\mathrm{pH}$ values. The sorption for selenate increased sharply from $\mathrm{pH} 1$ to a maximum of $76 \%$ at $\mathrm{pH} 2$ and then decreased steadily to less than $5 \%$ between $\mathrm{pH}$ values ranging from 6 to 8 . The selenite sorption increased from about $35 \%$ at $\mathrm{pH} 1$ to $80 \%$ between $\mathrm{pH} 3$ and 4 and the decreased gradually to around 40 $\%$ between $\mathrm{pH} 6$ and 8 . Arsenite sorption started from $20 \%$ between $\mathrm{pH}$ values of $1-3$ and then increased sharply to a maximum $78 \%$ at $\mathrm{pH} 4$ from by an abrupt decrease between $\mathrm{pH}$ 6 and 8 to values less than $5 \%$. There was a gradual increase in arsenate sorption from 0.4 $\%$ at $\mathrm{pH} 1$ to about $75 \%$ at $\mathrm{pH} 8$.

Information obtained from the kaolin and silica gel sorption studies is important in determining the extent to which arsenic and selenium can adsorb/sorb onto solid surfaces. Considering that kaolin is ubiquitous in river sediments, there is a greater chance of finding more $\mathrm{Se}(\mathrm{VI})$ and As (III) in river waters at $\mathrm{pH} \geq 5$ than $\mathrm{Se}$ (IV) and As (V) because of their low affinities shown in Figure 40. It follows that selenates are more mobile and predominant in river systems compared to selenites; however, selenites are more toxic ${ }^{118}$. Recently it was reported that arsenite could be more prevalent in natural waters than previously thought because it exists as the neutral $\mathrm{H}_{3} \mathrm{AsO}_{3}{ }^{119}$ The neutrality of the arsenite species could be responsible for the low affinity with the kaolin and silica gel at high $\mathrm{pH}$ values. The results suggests that As (III) is more mobile in reducing aquatic systems 
compared to As (V) ${ }^{120}$ In oxidizing environments arsenic species can be oxidized to As (V) which has a higher affinity for the sediments and this could explain why arsenic concentrations in river waters were below the limit of detection. Such sorption characteristics can also be used to study procedures suitable for cleaning up contaminated industrial and domestic effluents using silica and kaolin. Silica gel is not a good choice for the removing any of the chemical species studied because of poor sorption efficiency. Kaolin is a good candidate for the explorations because it has a higher affinity for all the selenium and arsenic species studied at different optimal $\mathrm{pH}$ values

\section{Selenate sorption on kaolin and associated redox kinetics Optimization of humic acid sorption on kaolin}

The calibration curve for the determination of the absorbance of HA at $300 \mathrm{~nm}$ is shown in Figure 41 and the results from the preliminary sorption experiments for humic acid on kaolin are also shown in Figure 42. The maximum sorption of $90 \%$ occurred at $\mathrm{pH}$ 4 which corresponds to the point zero charge (Pzc) of kaolin. ${ }^{121}$ The carboxylate, phenolic hydroxyl functional groups and other acidic moieties in humic acids are also protonated at low $\mathrm{pH}$ and therefore most of them are neutral. The high affinity at $\mathrm{pH} 4$ can therefore be explained in terms of attractive hydrophobic interactions between the neutral humic acid molecules and the neutral surface on kaolin at Pzc. At low pH there is a high density of positive charges on the kaolin that hinders the sorption of humic acid. At high $\mathrm{pH}$ the humic acids and the kaolinitic surfaces are deprotonated and therefore they both have negative charges which introduce electrostatic repulsions that decrease the HA sorption affinity on kaolin. It follows that the affinity of kaolin towards humic acids stabilized at 90 $\%$ at $\mathrm{pH} 4$ and at $65 \%$ at $\mathrm{pH} 7$ (Figure 43 ). 


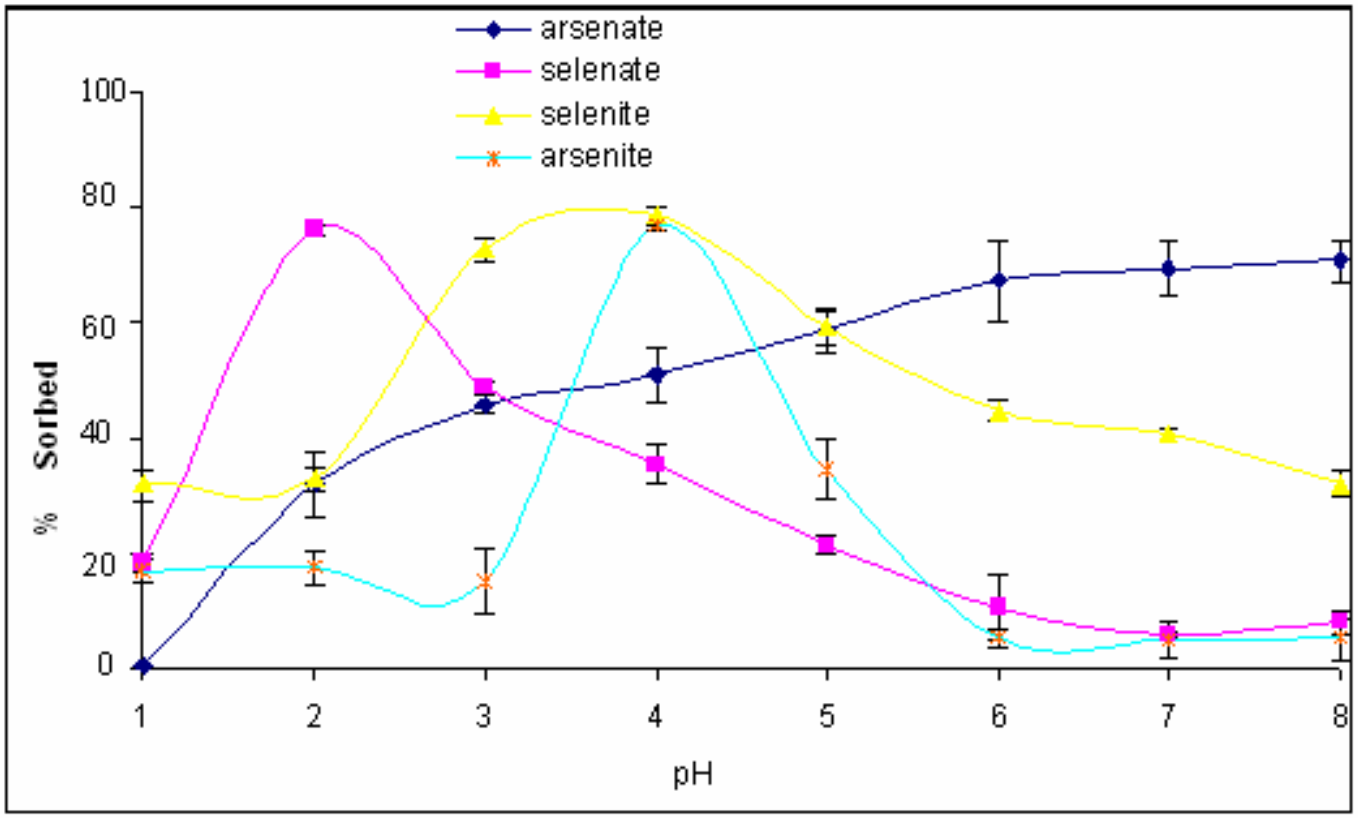

Figure 40: Sorption of selenite, selenate, arsenite and arsenate on kaolin as a function of $\mathrm{pH}$

Conditions: $1 \mathrm{~g}$ treated kaolin, Ionic strength $=2 \mathrm{mM}$ as $\mathrm{NaCl}$, with $50 \mathrm{ng} / \mathrm{L}$ arsenite, arsenate, selenate or selenite standards. 


\section{Kinetic reductions of selenate on kaolin and humic acids}

Kinetics experiments for the reduction of selenate with humic acid and kaolin were done at $\mathrm{pH} 4$ and 7. HA alone at a concentration of $4.4 \mathrm{mg} / \mathrm{L}$ is not effective in reducing selenate ions at $\mathrm{pH} 7$, as shown in Figure 44. A sudden initial increase in selenite concentrations reaching a maximum of $2.5 \mathrm{ng} / \mathrm{mL}$ after 4 hours followed by a slow decrease thereafter was observed for the kaolin-based reactions. The immediate disappearance of selenite from solution suggests that selenite species are intermediates that are used up or complexed in a follow up reaction. The transient appearance of the Se (IV) can be used to confirm the assertions made by Johnson (2004) ${ }^{122}$ who suggested that $\mathrm{Se}(\mathrm{VI})$ is reduced to $\mathrm{Se}(-\mathrm{II})$ in a stepwise fashion through $\mathrm{Se}(\mathrm{IV})$ and $\mathrm{Se}(0)$ intermediates. An initial increase in the accumulation of selenite concentration that reached a maximum value of $2.0 \mathrm{ng} / \mathrm{mL}$ between 1-2 hours at $\mathrm{pH} 4$ as illustrated in Figure 44 . The reduction reaction is faster at $\mathrm{pH} 4$ than at $\mathrm{pH} 7$ as shown in Figures 44 and 45 respectively. It took approximately 4 hours at $\mathrm{pH} 7$ and 2 hours at $\mathrm{pH} 4$ to reach the respective maximum concentrations. The follow up disappearance of the transient Se (IV) peak was also faster at $\mathrm{pH} 4$ than at $\mathrm{pH} 7$. Thus selenite concentration decreased by almost $25 \%$ within 8 hours (from 4 hours to 12 hours of reaction) at $\mathrm{pH}$ 7(Figure 44) while at $\mathrm{pH} 4$, the selenite concentration decreased by roughly $75 \%$ within a period of 3 hours (from 2 to 5 hrs of reaction in Figure 45). Interestingly, even HA alone is capable of reducing Se (VI) to Se (IV) at $\mathrm{pH}$ 4. It has been reported that compounds with polycarboxylic acids functional groups such as ascorbic acid can reduce Se (IV) to Se (0). ${ }^{123}$ It appears kaolin enhances the reduction probably due to the presence of catalytic $\mathrm{TiO}_{2}$ impurities. ${ }^{124}$ This could be the reason why more selenite was produced in kaolin-based experiments compared to HA alone 


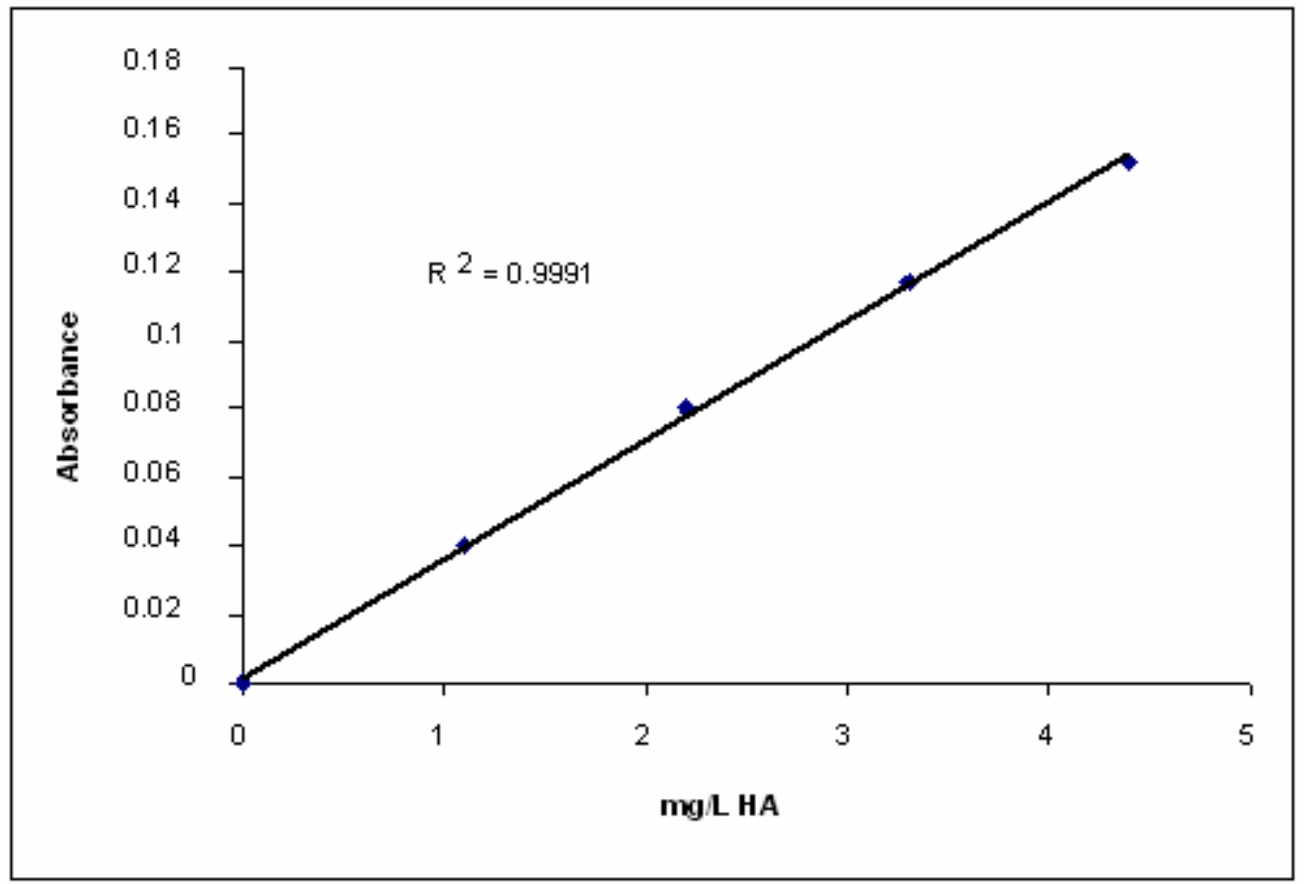

Figure 41: Calibration curve for the determination of humic acid (HA) 


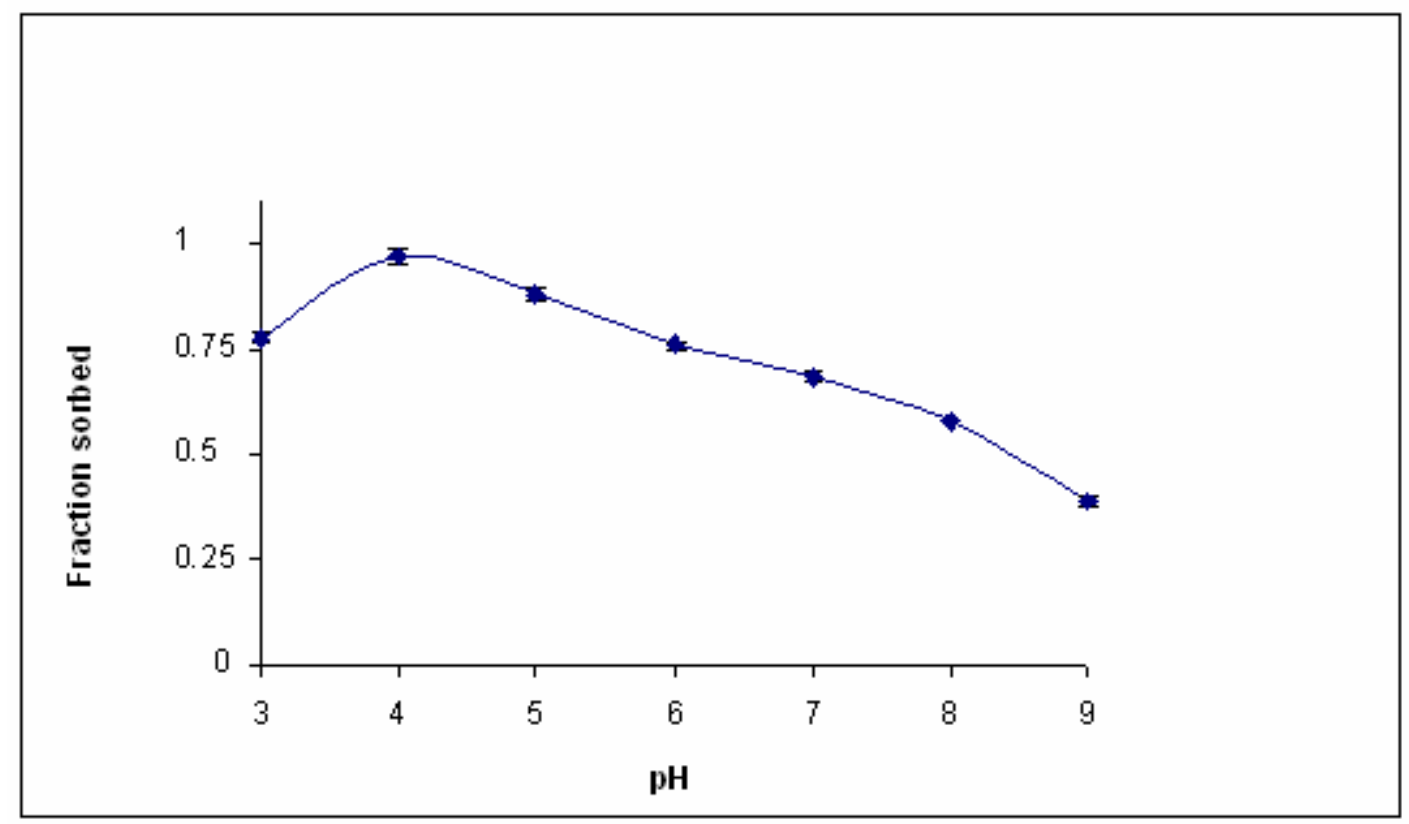

Figure 42: Sorption of humic acid on kaolin

Conditions: Ionic strength as $2 \mathrm{mM} \mathrm{NaCl}, 1 \mathrm{~g}$ treated kaolin and $4.4 \mathrm{mg} / \mathrm{L}$ Humic acid 


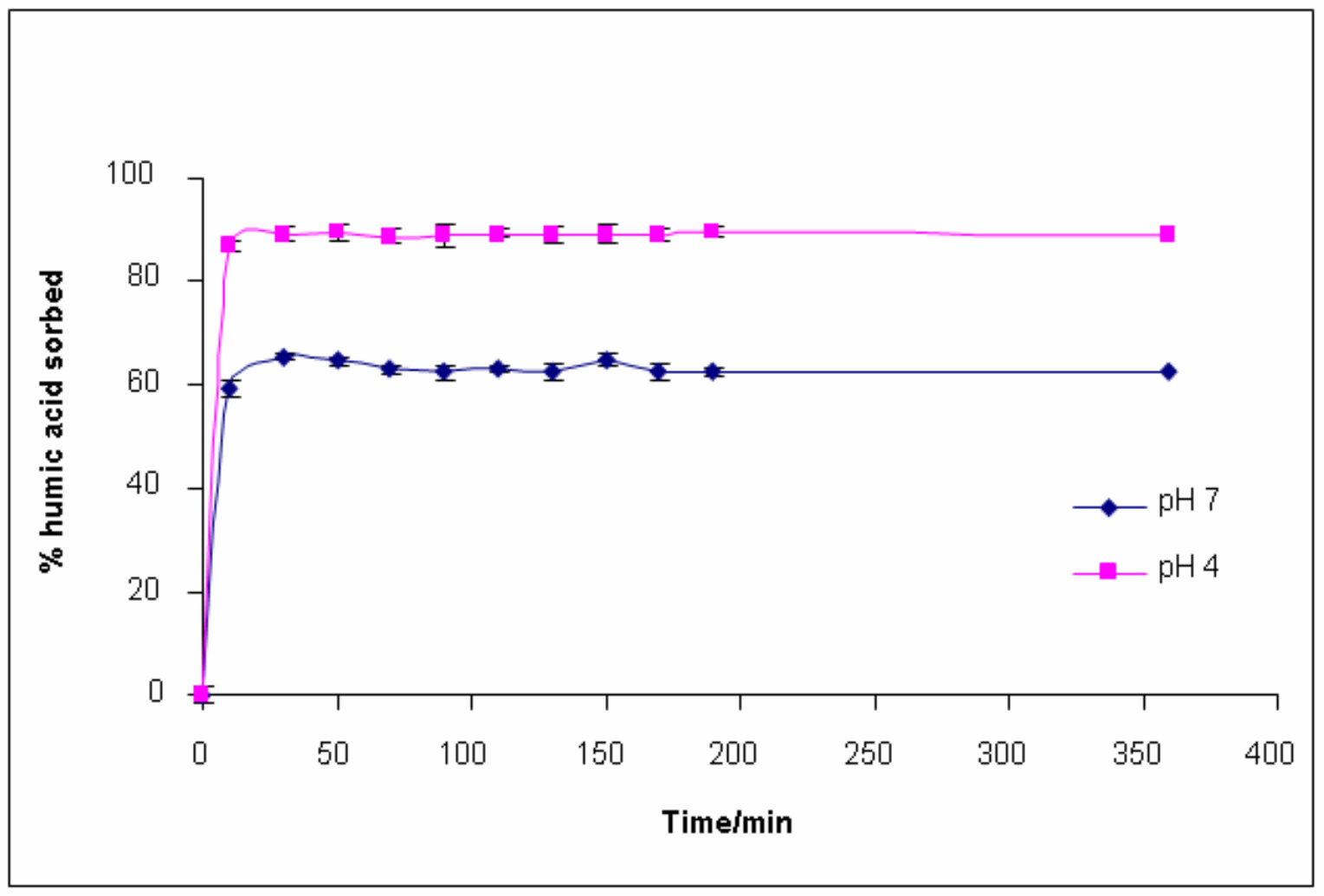

Figure 43: Optimization of the sorption kinetics of humic acid on kaolin Conditions: Ionic strength as $2 \mathrm{mom} \mathrm{NaCl}, 1 \mathrm{~g}$ treated kaolin and $4.4 \mathrm{mg} / \mathrm{L} \mathrm{HA}$. 


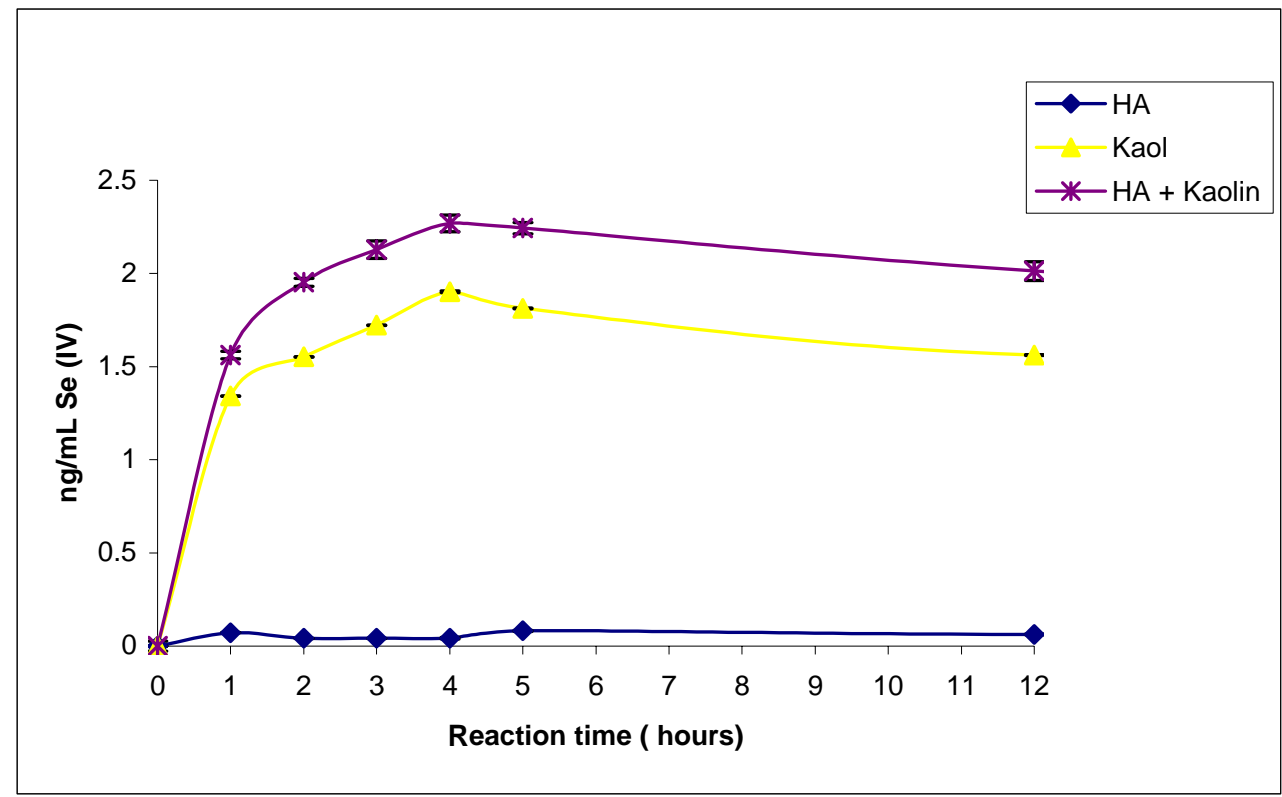

Figure 44: Reduction of $50 \mathrm{ng} / \mathrm{mL}$ Se (VI) to Se (IV) at $\mathrm{pH} 7$

Conditions: $1 \mathrm{~g}$ treated kaolin, Ionic strength $=2 \mathrm{mM}$ as $\mathrm{NaCl}$, with $50 \mathrm{ng} / \mathrm{L}$ selenate and $4.4 \mathrm{mg} / \mathrm{L}$ Humic acid (HA) 


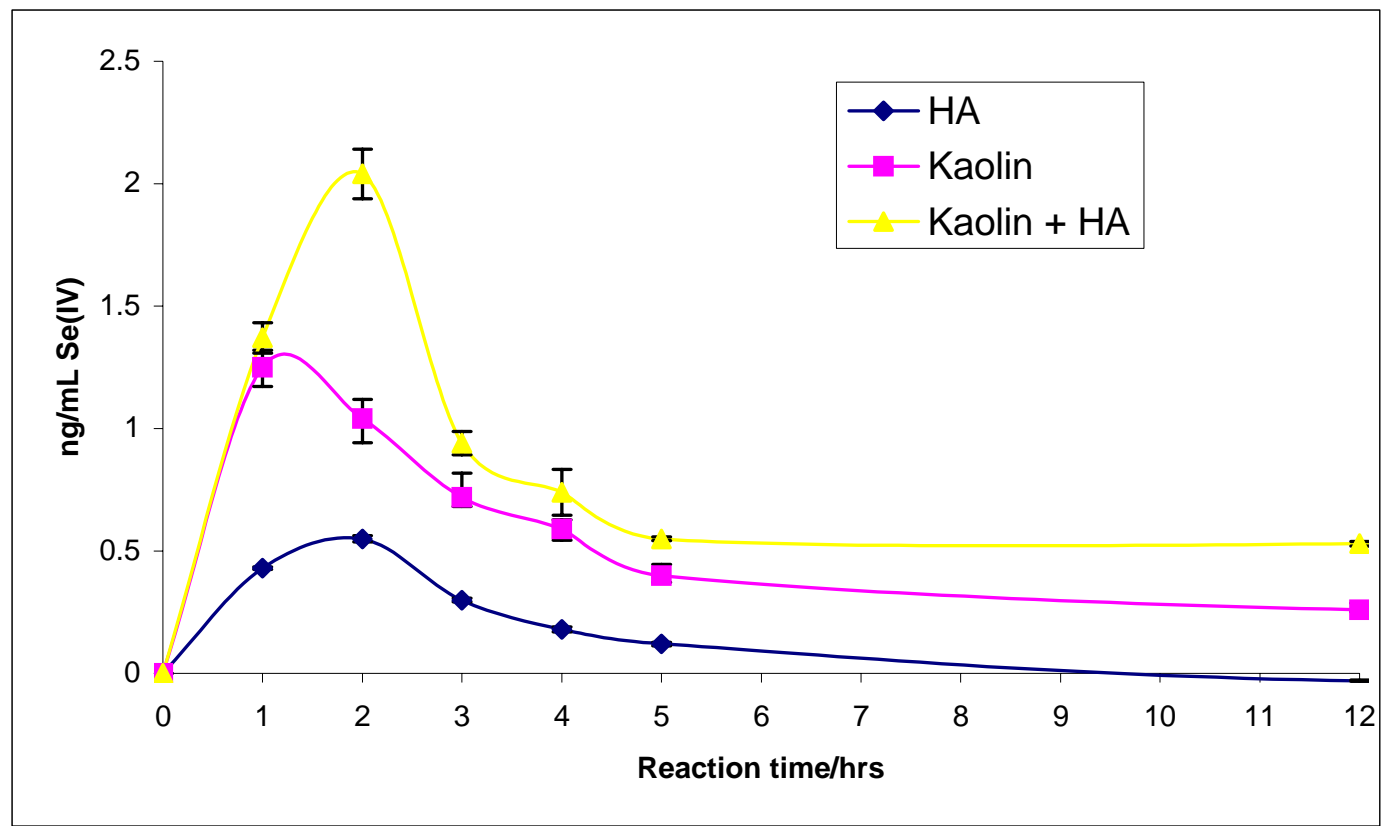

Figure 45: Reduction of $50 \mathrm{ng} / \mathrm{mL}$ Se (VI) at $\mathrm{pH} 4$

Condition: $1 \mathrm{~g}$ treated kaolin, Ionic strength $=2 \mathrm{mM}$ as $\mathrm{NaCl}$, with $50 \mathrm{ng} / \mathrm{L}$ selenate and $4.4 \mathrm{mg} / \mathrm{L} \mathrm{HA}$. 
at both $\mathrm{pH} 4$ and $\mathrm{pH}$ 7. A combination of humic acid and kaolin was superior in reducing selenate to selenite species compared to kaolin alone at both $\mathrm{pH}$ values. This could be as a result of competitive sorption between humic acid and the produced selenite species onto the surfaces of kaolin particles. Such competitive sorption is also responsible for the mobilization and reduced affinity of selenium species with kaolin. Hence the reason why natural organic matter plays a crucial role in controlling the concentrations of water soluble selenium and $\operatorname{arsenic}^{125}$ in the environment. In reactions with kaolin alone the sorption of selenite was not hindered resulting in reduced solution selenite concentrations. Reactions involving both kaolin and humic acid produced higher aqueous selenite concentrations because some of sorption sites on kaolin were occupied by HA and therefore not available for selenite adsorption/sorption.

\section{Quality assurance}

A United States Geological Survey (USGS) Green River certified reference shale (SGR-1b) was analysed using both sequential extraction and microwave digestion followed by the analysis of the digests. The difference in concentrations between the total combined extracts and the microwave digestions are less than $5 \%$ for the total selenium and arsenic concentrations. Results from microwave extractions are compared to certified values as shown in Table 15.Continuous sonication for 20 minutes in nanopure water resulted in the extraction of only the water and phosphate buffer extracts. Se (IV) concentration was $14 \pm 2$ $\mathrm{ng} / \mathrm{g}$ and total Se was $59 \pm 3 \mathrm{ng} / \mathrm{g}$ and arsenic concentrations were below the limit of detection in these extracts. Results obtained from sonicated extracts are very close to the combined water and phosphate buffer extracts as shown in Table 15. 


\section{\% Recoveries}

About $0.4 \mathrm{~g}$ sample of BT 290 sample was spiked with $50 \mu \mathrm{g}$ ( $50 \mu \mathrm{L}$ of $1000 \mathrm{ppm}$ standard) arsenic and $1000 \mathrm{ng}(100 \mu \mathrm{L}$ of $10 \mathrm{ppm})$ selenium, microwave digested as described in chapter 2 and then analysed for arsenic and selenium in the resultant $50 \mathrm{~mL}$ solution. Three spiked samples were run parallel with three unspiked ones. The averaged \% recoveries are shown in Table 16. 


\begin{tabular}{|c|c|c|c|c|c|c|c|c|c|}
\hline & $\begin{array}{l}\text { Water } \\
\text { soluble } \\
\mathbf{n g} / \mathbf{g}\end{array}$ & $\begin{array}{l}\text { Phosphate } \\
\text { Buffer } \\
\mathbf{n g} / \mathbf{g}\end{array}$ & $\begin{array}{l}1 \mathrm{M} \mathrm{NaOH} \\
\text { Soluble } \\
\mathbf{n g} / \mathbf{g}\end{array}$ & $\begin{array}{l}\text { Acid } \\
\text { soluble } \\
\mathbf{n g} / \mathbf{g}\end{array}$ & $\begin{array}{l}\text { Residual } \\
\boldsymbol{\mu g} / \mathbf{g}\end{array}$ & $\begin{array}{l}\text { Total } \\
\text { combined } \\
\text { extracts } \\
\boldsymbol{\mu g} / \mathbf{g}\end{array}$ & $\begin{array}{c}\text { Microwave } \\
\text { extraction } \\
\qquad \boldsymbol{\mu g} / \mathbf{g}\end{array}$ & $\begin{array}{l}\text { Certified } \\
\text { Values } \\
\boldsymbol{\mu g} / \mathbf{g}\end{array}$ & RSD \\
\hline $\mathrm{Se}(\mathrm{IV})$ & $13 \pm 1$ & N.D. & $730 \pm 138$ & $162 \pm 3$ & - & $743 \pm 138$ & - & - & - \\
\hline $\begin{array}{l}\text { Total } \\
\text { Se }\end{array}$ & $60 \pm 3$ & N.D. & $360 \pm 16$ & $68 \pm 10$ & $3.3 \pm 0.4$ & $3.9 \pm 0.4$ & $3.7 \pm 0.2$ & 3.5 & $6 \%$ \\
\hline $\begin{array}{l}\text { Total } \\
\text { As }\end{array}$ & N.D. & N.D. & $9741 \pm 236$ & $269 \pm 25$ & $57 \pm 13$ & $67 \pm 13$ & $70 \pm 4$ & $67 \pm 5$ & $4 \%$ \\
\hline
\end{tabular}

Table 15: Comparison of experimental and certified concentrations of arsenic and selenium in the USGS Green river shale reference material. 


\begin{tabular}{|l|l|l|l|c|}
\cline { 2 - 5 } \multicolumn{1}{c|}{} & $\begin{array}{l}\text { mg/kg in the } \\
\text { original } \\
\text { sample }\end{array}$ & $\begin{array}{l}\mathbf{m g} / \mathbf{k g} \\
\text { added }\end{array}$ & $\begin{array}{l}\text { total } \mathbf{~ m g} / \mathbf{k g} \\
\text { after } \\
\text { spiking }\end{array}$ & \% Recoveries \\
\hline As & $60 \pm 3$ & $123 \pm 3$ & $195 \pm 5$ & 106 \\
\hline Se & $1.9 \pm 0.1$ & $2.458 \pm 0.005$ & $4.0 \pm 0.2$ & 92 \\
\hline
\end{tabular}

Table 16: Recoveries for arsenic and selenium 


\section{Summary}

The leaching of waste from valley fills contributes selenium and arsenic into main waterways. Selenium concentrations in water at MT 18 and MT34 B sampling locations continue to violate the WV stream standard. Selenium concentration at MT15 and MT18 decreased over a period of seven years but remaining almost constant at MT 34B during the same period. The sediment MT 34B had the highest amount of extractable selenium and arsenic. The $\mathrm{NaOH}$ extract had the most concentrations of both selenium and arsenic indicating that these two are closely associated with organic molecules. Most of the selenium in MT 34B was selenite. The MT 34B sediment had a muddy appearance whereas MT15 and MT 18 sediments appeared to be sandy. The collected background water samples did not contain detectable amounts of arsenic and selenium. The $50 \%$ variation in arsenic concentration in the background samples could indicate that some of these samples were collected in places that were already contaminated with arsenic. Oxidation of arsenic species in the generally oxidizing West Virginian streams could have resulted in the formation of As (V) that binds strongly to solid surfaces leading to the sequestration of arsenate species and low concentrations in water. Background sediments samples contained selenium concentrations that were 3-10 times lower than those of MT15, MT18 and MT34B.

Selenate reduction is dependent on the $\mathrm{pH}$, sediment (kaolin) and presence of humic acids. It has been shown that humic acids alone cannot reduce selenate at high $\mathrm{pH}$ probably due to electrostatic repulsions. However, there is significant reduction at low $\mathrm{pH}$. The presence of $\mathrm{TiO}_{2}$ impurities on kaolin provides a catalytic pathway for the reduction of selenate. The presence of a Se (IV) transient peak could suggest that the 
selenate reduction passes through a selenite intermediate. Hence kaolin, a major component of river sediment plays a critical role in the sorption, redox conversions and the remobilization of selenium species. 


\section{Chapter 5: Interstitial Location of Selenium and Arsenic in Coal Associated Rocks}

\section{Introduction}

As outlined in previous chapters, significant amounts of selenium and arsenic can be released from coal mining waste rock. The amounts released are a reflection of how the selenium and arsenic are bound to the rock surfaces and this depends on the location of arsenic and selenium species in the rock minerals. Hence the sorption and mineralization of organic compounds containing arsenic and selenium before the lithification process plays a critical role in the localization of these metalloids. Organic matter from phytoplankton and other sources has been shown to sorb and be preserved on clay minerals and soils ${ }^{126}$ and chlorite was found to have the highest adsorption partition coefficient compared to montmorillonite and kaolinite. ${ }^{126}$ Such sorption interactions can introduce selenium and arsenic previously complexed by organic molecules into the rock lattice for intercalation, preservation and lithification. ${ }^{127}$ The sites for preservation can depend on the affinities and the reactivities ${ }^{126}$ of different rock constituents including the presence of bio-geochemically active microorganisms. ${ }^{128}$

\section{Structures of phyllosilicate clays ${ }^{129}$}

Phyllosilicates are sheet silicate minerals with stacked sheet layers that are either 1:1 layers (layers composed of a tetrahedral sheet where $\mathrm{Si}$ is the cation, associated with an octahedral sheet containing $\mathrm{Al}, \mathrm{Mg}$, or Fe cations), or 2:1 layers (where the octahedral sheet is sandwiched between two tetrahedral sheets). ${ }^{130}$ The tetrahedral layer consists of silica tetrahedra that are connected together by sharing terminal oxygen atoms. The octahedra contains six hydroxide moieties surrounding $\mathrm{M}^{3+}\left(\mathrm{Fe}^{3+}\right.$ or $\mathrm{Al}^{3+}$ in dioctahedral lattices) or $\mathrm{M}^{2+}\left(\mathrm{Fe}^{2+}, \mathrm{Al}^{2+}\right.$, or $\mathrm{Mg}^{2+}$ in trioctahedral lattices $)$ ions. The 
tetrahedral and octahedral layers can be linked on a 1:1 ratio (one tetrahedral layer -one octahedral layer) to form two layered clays or on a 2:1 ratio (tetrahedral-octahedraltetrahedral) to form three layered clay structures. This aluminosilicate backbone is most common in phyllosilicates. Vermiculite, montmorrillonite, chlorite, illite and kaolinite are the most common clays in sedimentary rocks and their structures are shown in Figures 46-50.

\section{Kaolinite}

Kaolinite (Figure 46) is a group of two layered 1:1 clays that show basal repeat unit of $7 \AA$. The kaolinite has a small and inaccessible interlayer spacing between the tetrahedral and octahedral layers. The two layers are held together and stabilized by pseudo-hydrogen bonding through hydroxide linkages.

\section{Illite}

Illite (Figure 47) is a 2:1 dioctahedral clay mineral that has a repeat unit of $12 \AA$. It has two negatively charged tetrahedral ends that sandwich a $\mathrm{K}^{+}$layer. The positively charged $\mathrm{K}^{+}$layer "glues" the two negatively charged surfaces by electrostatic attractions. Illite is thought to be a weathering product of mica. Mica has about $30 \%$ more $\mathrm{K}^{+}$ions in the interlayer and consequently a smaller repeat unit $(10 \AA)$ as a result of relatively stronger electrostatic attractions.

\section{4 Ád Spacing Clays}

\section{Montmorillonite}

Montmorrillonite (Figure 48) has reduced concentration of $\mathrm{K}^{+}$ions in the interlayer compared to illite. Because of the loss of $\mathrm{K}^{+}$ions, the sheets are not strongly 


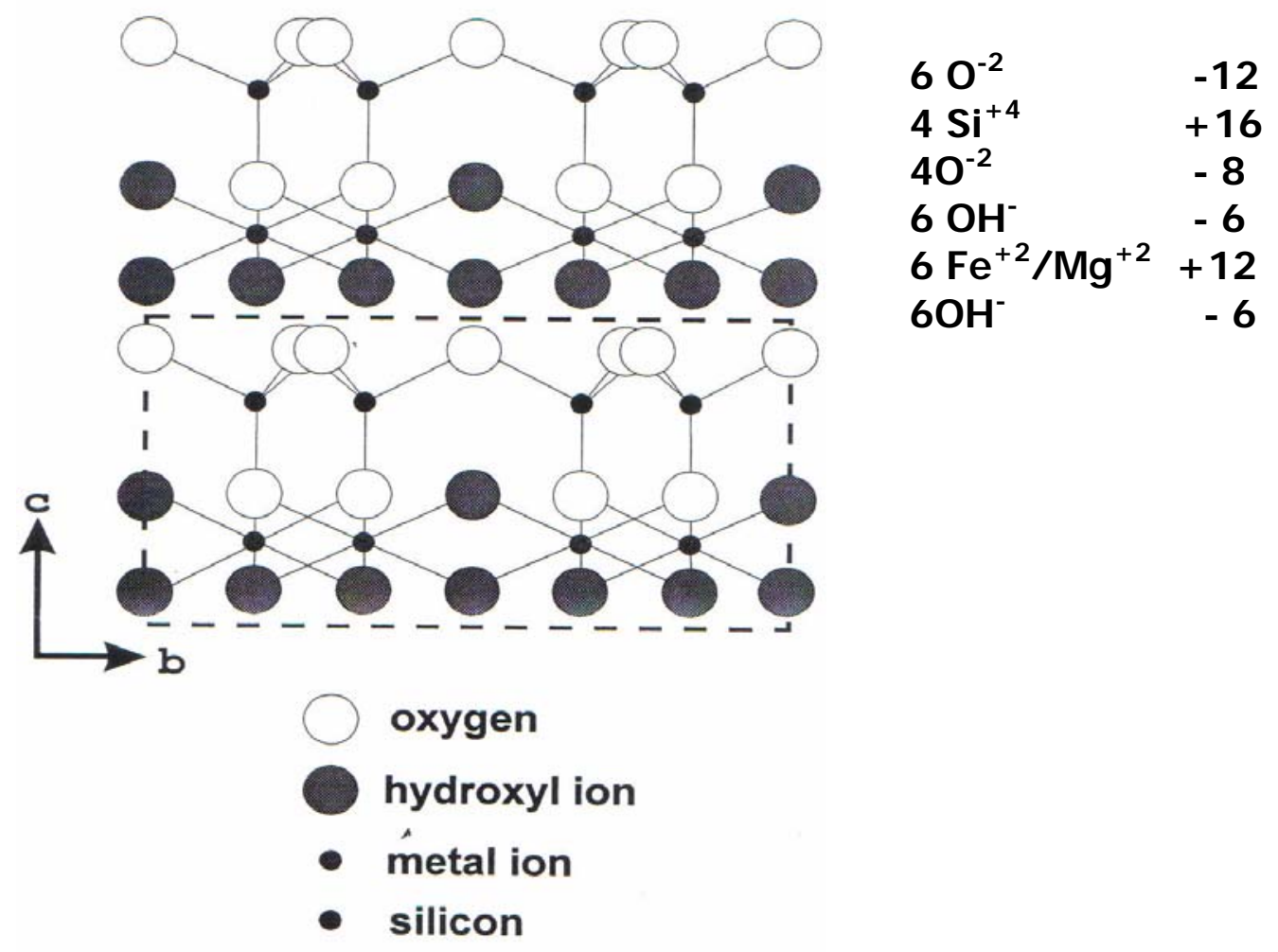

Figure 46: The structure of kaolinite (with contributing charges on the silicon tetrahedral and the $\mathrm{Fe}^{+2} / \mathrm{Mg}^{+2}$ octahedral $)^{131}$ 

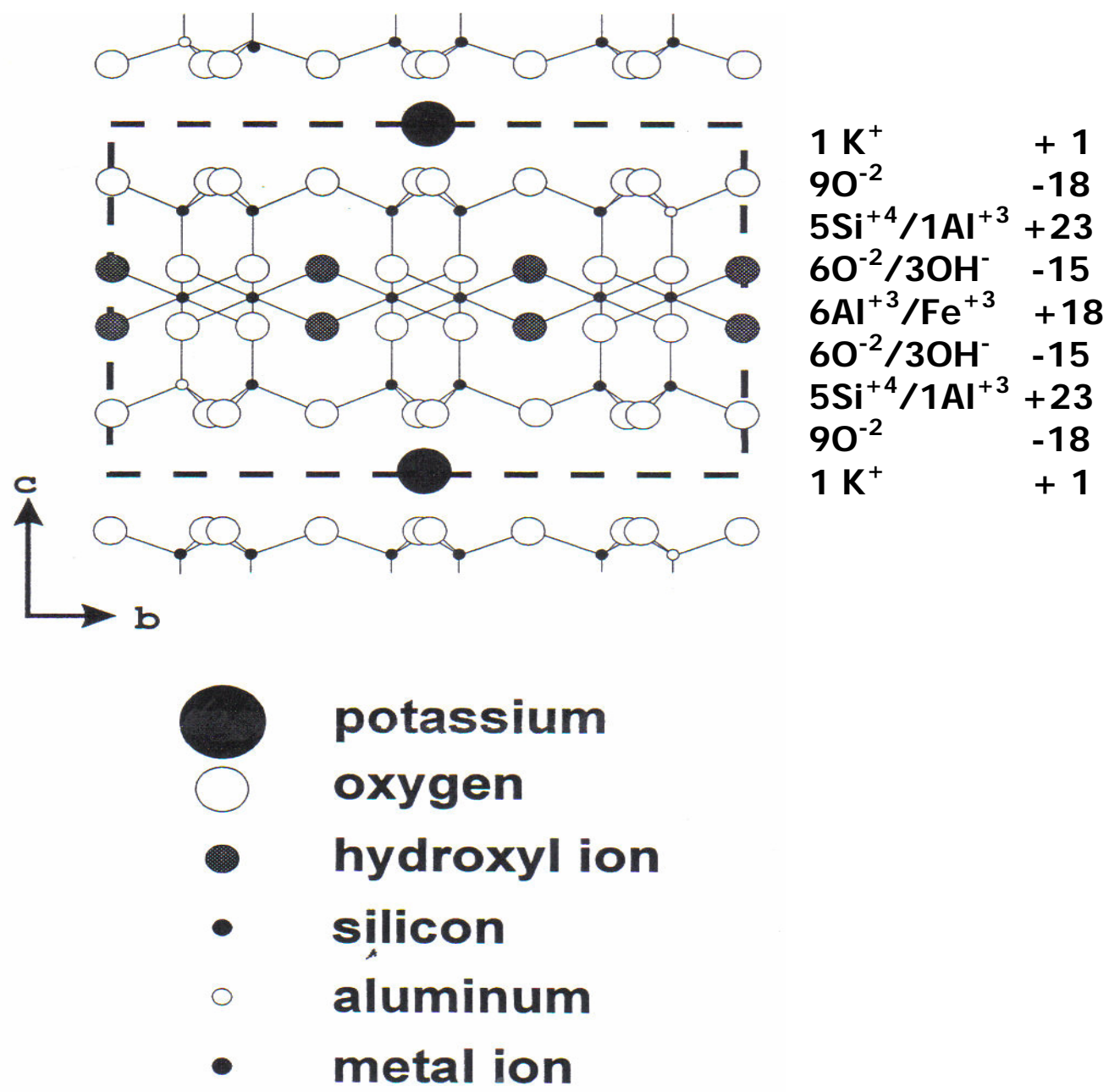

Figure 47: The structure of illite ${ }^{131}$ 


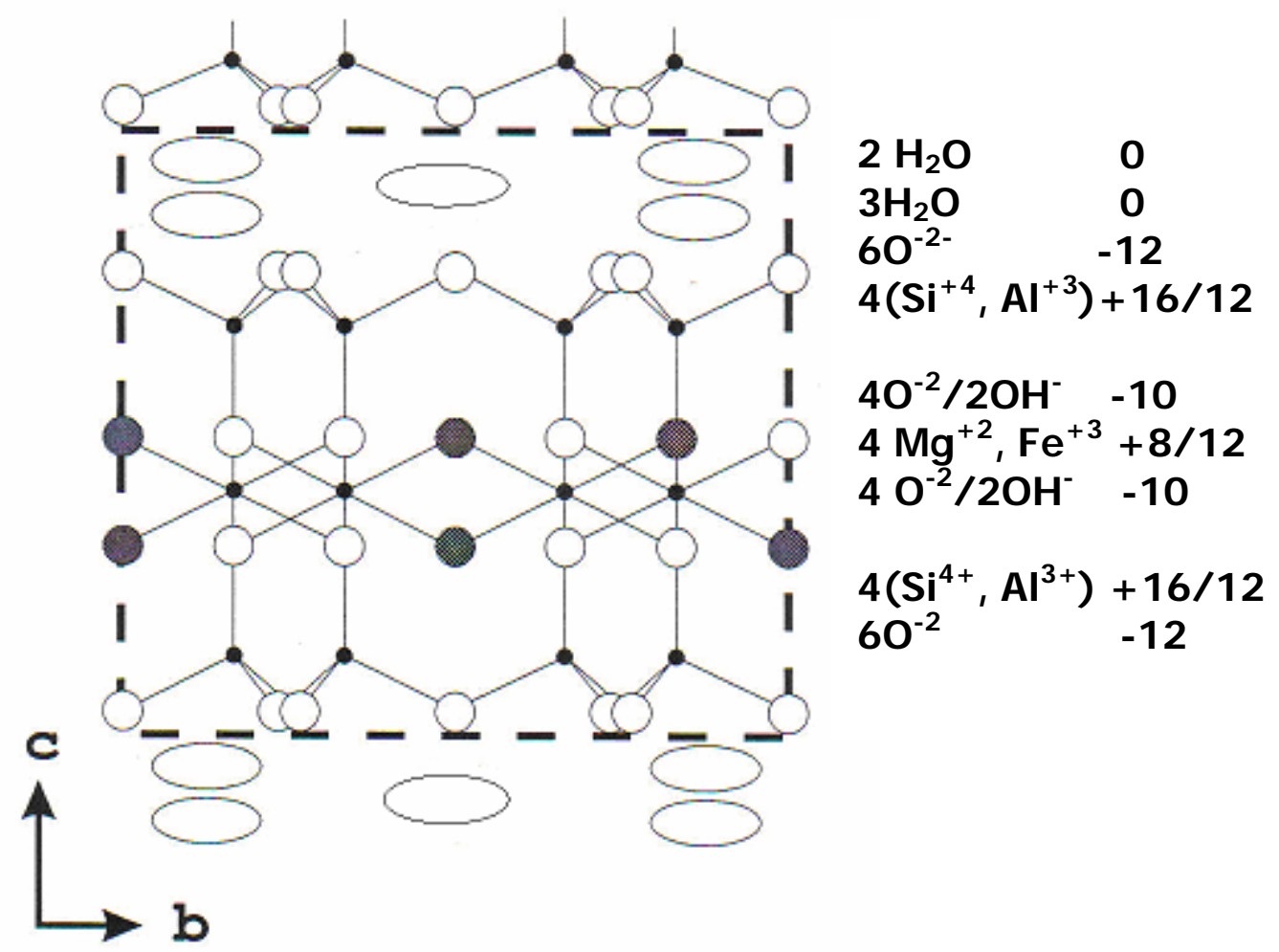

$\infty$ water molecule

$\bigcirc$ oxygen

- hydroxyl ions

- silicon

- metal ions

Figure 48: The structure of montmorillonite ${ }^{131}$ 

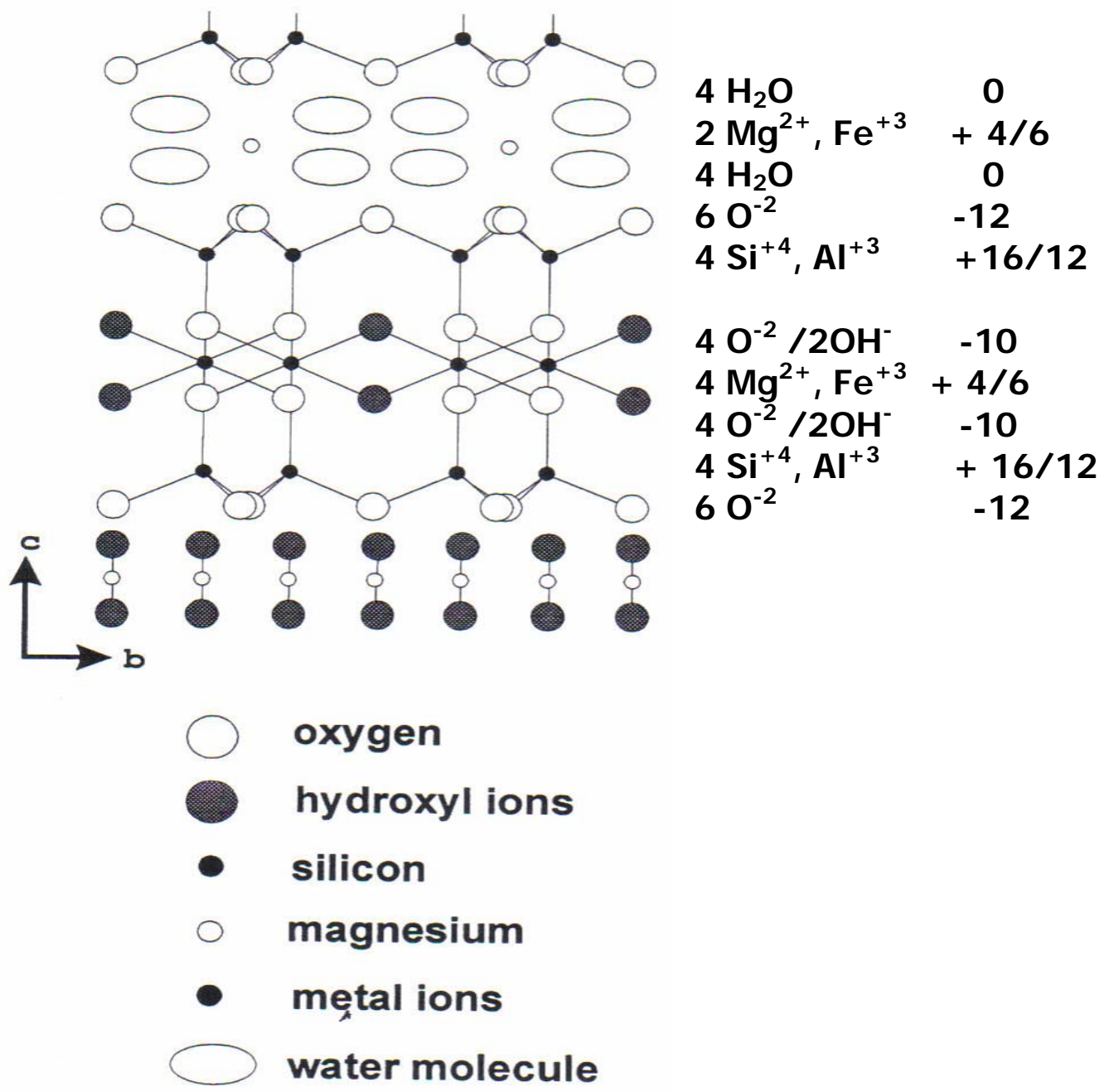

Figure 49: The structure of vermiculite ${ }^{131}$ 


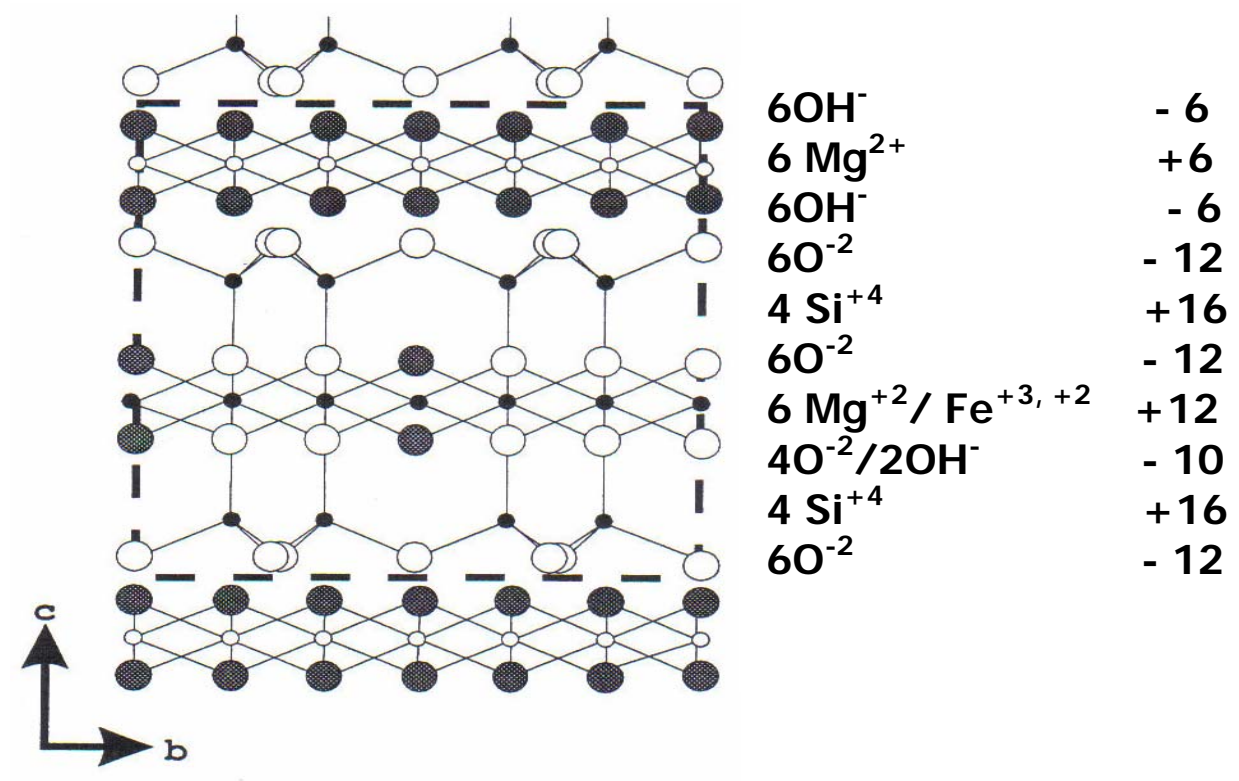

hydroxyl ions

$\bigcirc$ oxygen

- silicon

$\bigcirc$ magnesium

- métal ions

Figure 50: The chlorite structure ${ }^{131}$ 
bonded as in illite and therefore allow the entry of water molecules into the interlayer that surround the remaining $\mathrm{K}^{+}$ions. The guest water molecules in the interlayer increase the d spacing to 14 Á. The variance in the amount of water that can enter the interlayer is the basis behind the expandable nature of montmorillonite.

\section{Vermiculite}

The structure is similar to montmorrillonite in that it has a basal repeat unit of 14 $\AA$ Á. Vermiculite(Figure 49) is a trioctahedral and instead of having $\mathrm{K}^{+}$in the interlayer position it has hydrated $\mathrm{Mg}^{2+} / \mathrm{Fe}^{2+}$ ions. Because the interlayer ions are divalent, the structures are held more strongly compared to illite.

\section{Chlorite}

Chlorite (Figure 50) is a 2:1 dioctahedral that has a basal spacing of $14 \AA$. It is similar to illite but instead of the $\mathrm{K}^{+}$in the interlayer there is an octahedral brucite (Mg $\left.(\mathrm{OH})_{2}\right)$ or gibbsite $\left(\mathrm{Al}(\mathrm{OH})_{3}\right)$ layer. It is the most thermally and chemically stable among all phyllosilicates. The substitution of $\mathrm{Mg}^{2+}$ by $\mathrm{Al}^{3+}$ in the brucite creates positive charges in the $\mathrm{Mg}(\mathrm{OH})_{2}$ that joins together the two adjacent tetrahedral layers by electrostatic attractions.

\section{Principal component analysis ${ }^{132-137}$}

Principal component analysis (PCA) is an unsupervised non-parametric multivariate statistical technique that can be used to identify relationships and similarities between samples and variables. Principal component analysis is used to reduce data dimensionality by identifying similar patterns and variables and introducing new latent variables which are linear combinations of the observed or measured variables. This allows pattern recognition and the streamlining of large data sets to smaller and easier to 
handle pieces of information. PCA begins with normalization and standardization of data to give appropriate weighting. This transformation converts all sample results into $\mathrm{z}$ scores. A plot of the z scores between any two data sets will lead to existing or new linear relationships/combinations or clustering of data points with similar attributes. The new linear combinations are known as principal components (PCs). Placing a meaning on the derived PCs or clusters requires a thorough knowledge of the chemistry and the physical properties of the samples analysed. Variables are mapped into loadings which are defined as their individual contributions to a principal component (PC). The higher the loading the stronger is the variable contribution to a PC. A variable can have either a positive or negative contribution to a PC which is indicated by the sign on the loading. The combined variance of all PCs used should explain at least more than $80 \%$ of the total variance observed. However in most situations the first two PCs that explain the largest variance are used in the initial screening. The PCs generated are orthogonal to each other. In large data sets, a multi-step clustering using PCA is essential to deconvolute and streamline data into related sub-components or sub-clusters that can be further decomposed by a follow up PCA to identify closely related parameters. The superimposition of a Score plot onto a Loading plot is known as a Biplot ${ }^{138}$ which provides direct details on the relationship between samples and variables.

\section{Sampling}

The dominant clay minerals in the coal-associated rocks were kaolinite and illite with lesser amounts of $14 \AA$ d spacing clays. At least 10 samples were randomly selected containing higher amounts of at least one of the following: \% $14 \AA \mathrm{d}$ spacing clays, \% kaolinite, or \% illite. These samples also contained appreciable amounts of quartz, 
plagioclase and K-feldspar (orthoclase). A total of 48 pulverized samples were selected in this procedure. Samples are identified by a number that corresponds to the collection depth in feet.

\section{Experimental}

Arsenic and selenium were extracted from the samples using the ultrasound extraction procedure described in Chapter 3. Averaged results from the analysis of extracts using are given in Tables 17 and 18 together with their respective lithologies. Mineral and elemental analyses of other samples were also performed (Appendix 1C), courtesy of WVGES.

\section{Results and discussion}

\section{Primary PCA analysis}

Application of the principal components analysis using Minitab15.0 (Minitab

Inc.) generated 18 orthogonal principal components and the first eight explained $94.6 \%$ of the variation. All of the 18 principal components and their respective eigenvalues are shown on a scree plot in Figure 51. The variable contribution to the first eight PCs and their eigenvalues are given in Table 19. The first three PCs (PC 1, PC 2 and PC 3) explained $74.0 \%$ of the total variance within all the measured parameters.

PC 1 largely describes the variation trace elemental composition and PC 2 explains lithology properties and PC 3 describes combined selenium variation.

The loading plot between PC 1 and PC 2 shown in Figure 52 clusters has four distinct groups A, B, C and D. Two clusters (A and B) are made up of two unique lithologies of sandstones that are based on the amounts of orthoclase feldspar $\left(\mathrm{KAlSi}_{3} \mathrm{O}_{8}\right)$ 


\begin{tabular}{|c|c|c|c|c|c|c|c|}
\hline $\begin{array}{l}\text { Sample } \\
\text { numbe }\end{array}$ & $\begin{array}{l}{ }^{a} \text { Quart } \\
r \%\end{array}$ & $\begin{array}{l}\mathrm{z}^{\mathrm{a}} \mathrm{K} \text {-Feldspar } \\
\%\end{array}$ & $\begin{array}{l}{ }^{\mathrm{a}} \text { Plagioclase } \\
\quad \%\end{array}$ & $\begin{array}{l}{ }^{\mathrm{a}} \text { Illite } \\
\%\end{array}$ & $\begin{array}{l}{ }^{a} \text { Kaolinite } \\
\%\end{array}$ & $\begin{array}{c}{ }^{\mathrm{a}} 14 \AA \hat{\AA} \text { Clays } \\
\%\end{array}$ & s ${ }^{\mathrm{b}}$ Lithology \\
\hline 25 & 29.9 & 1.5 & 1.1 & 46.1 & 21.4 & 0.00 & Sandstone \\
\hline 60 & 81.0 & 3.2 & 0.0 & 6.80 & 9.10 & 0.00 & Sandstone \\
\hline 61 & 75.3 & 4.9 & 0.0 & 9.60 & 9.40 & 0.90 & Sandstone \\
\hline 125 & 53.8 & 0.9 & 1.2 & 25.3 & 14.9 & 4.00 & Claystone \\
\hline 157 & 70.6 & 3.9 & 0.3 & 10.4 & 11.8 & 2.50 & Sandstone \\
\hline 181 & 44.9 & 1.2 & 1.5 & 37.8 & 7.50 & 7.10 & Shale \\
\hline 211 & 60.9 & 3.9 & 0.7 & 16.9 & 13.6 & 3.90 & Siltstone \\
\hline 241 & 54.0 & 1.9 & 0.9 & 25.7 & 10.9 & 6.70 & Claystone \\
\hline 278 & 68.0 & 4.6 & 0.5 & 11.5 & 11.0 & 2.00 & Shale \\
\hline 290 & 32.6 & 1.1 & 1.3 & 38.4 & 11.9 & 14.7 & Shale \\
\hline 299 & 38.2 & 1.4 & 1.6 & 39.2 & 11.3 & 8.40 & Shale \\
\hline 305 & 47.1 & 1.0 & 1.3 & 29.6 & 9.00 & 12.0 & Siltstone \\
\hline 337 & 74.7 & 3.8 & 0.4 & 8.30 & 9.90 & 2.10 & Sandstone \\
\hline 369 & 14.4 & 0.0 & 0.9 & 60.2 & 12.3 & 8.10 & Claystone \\
\hline 372 & 29.8 & 1.4 & 0.8 & 35.7 & 11.9 & 20.4 & Shale \\
\hline 397 & 66.9 & 3.6 & 1.3 & 14.4 & 9.70 & 4.10 & Sandstone \\
\hline 404 & 39.5 & 2.4 & 1.2 & 23.5 & 12.3 & 21.0 & Shale \\
\hline 414 & 72.1 & 6.7 & 0.0 & 12.0 & 7.10 & 2.00 & Sandstone \\
\hline 432 & 59.7 & 6.5 & 0.0 & 10.8 & 21.5 & 1.50 & Sandstone \\
\hline 448 & 72.6 & 5.2 & 0.9 & 10.8 & 7.00 & 2.30 & Sandstone \\
\hline 479 & 65.3 & 5.0 & 0.0 & 9.10 & 18.4 & 1.40 & Sandstone \\
\hline 482 & 27.1 & 1.0 & 1.7 & 48.6 & 7.80 & 8.60 & Shale \\
\hline 486 & 61.3 & 2.4 & 5.6 & 20.5 & 5.00 & 5.20 & Sandstone \\
\hline 505 & 72.1 & 3.0 & 3.4 & 10.8 & 7.80 & 2.30 & Sandstone \\
\hline 519 & 67.4 & 4.4 & 4.0 & 14.4 & 6.40 & 2.50 & Sandstone \\
\hline 571 & 32.1 & 0.4 & 0.5 & 40.1 & 12.2 & 14.7 & Claystone \\
\hline 572 & 27.7 & 0.8 & 1.2 & 34.6 & 14.5 & 21.0 & Claystone \\
\hline 578 & 33.7 & 0.8 & 1.3 & 26.0 & 10.5 & 27.6 & Shale \\
\hline 581 & 47.4 & 1.6 & 0.8 & 26.6 & 13.3 & 10.3 & Shale \\
\hline 639 & 67.2 & 2.1 & 6.9 & 13.1 & 8.50 & 2.20 & Sandstone \\
\hline 677 & 25.2 & 0.8 & 1.0 & 39.0 & 9.80 & 24.2 & Shale \\
\hline 697 & 32.7 & 0.8 & 1.1 & 26.8 & 14.1 & 23.1 & Shale \\
\hline 699 & 28.8 & 0.0 & 1.0 & 50.3 & 6.30 & 13.6 & Claystone \\
\hline 700 & 22.6 & 0.5 & 0.9 & 46.6 & 7.50 & 21.9 & Claystone \\
\hline 701 & 25.2 & 1.2 & 1.3 & 44.9 & 7.60 & 19.8 & Claystone \\
\hline 719 & 61.7 & 3.6 & 8.1 & 15.4 & 6.50 & 4.40 & Sandstone \\
\hline 764 & 34.2 & 1.0 & 2.8 & 40.6 & 7.60 & 13.1 & Shale \\
\hline 769 & 27.0 & 1.0 & 1.2 & 47.0 & 9.90 & 12.5 & Shale \\
\hline 771 & 50.6 & 0.8 & 6.2 & 22.3 & 12.4 & 6.90 & Sandstone \\
\hline 776 & 30.0 & 1.0 & 1.3 & 44.5 & 9.50 & 13.7 & Siltstone \\
\hline 778 & 31.9 & 1.2 & 1.1 & 43.6 & 8.90 & 13.2 & Shale \\
\hline 791 & 56.0 & 2.9 & 0.7 & 21.7 & 11.1 & 7.60 & Sandstone \\
\hline 818 & 60.4 & 2.6 & 8.8 & 16.4 & 7.90 & 4.00 & Sandstone \\
\hline 831 & 28.5 & 1.2 & 0.8 & 37.7 & 8.90 & 23.0 & Siltstone \\
\hline 834 & 31.1 & 1.1 & 3.3 & 44.3 & 6.70 & 13.5 & Sandstone \\
\hline 857 & 49.5 & 1.3 & 7.7 & 22.3 & 12.9 & 6.30 & Sandstone \\
\hline 881 & 28.8 & 0.5 & 0.9 & 41.0 & 13.9 & 14.8 & Shale \\
\hline
\end{tabular}

Table 17: ${ }^{\mathrm{a} X}$ - ray diffraction and ${ }^{\mathrm{b}}$ microscopy results, courtesy WVGES ${ }^{7}$. 


\begin{tabular}{|c|c|c|c|c|c|c|c|c|c|c|c|c|}
\hline $\begin{array}{l}\text { Sample } \\
\text { number }\end{array}$ & $\begin{array}{l}{ }^{\mathrm{c}} \mathrm{K2O} \\
\%\end{array}$ & $\begin{array}{l}{ }^{\mathrm{c}} \mathrm{SiO}_{2} \\
\%\end{array}$ & $\begin{array}{c}{ }^{\mathrm{c}} \mathrm{Al}_{2} \mathbf{O}_{3} \\
\% \\
\%\end{array}$ & $\begin{array}{c}{ }^{\mathrm{c}} \mathrm{Fe}_{2} \mathrm{O}_{3} \\
\%\end{array}$ & $\begin{array}{l}{ }^{\mathrm{c}} \mathrm{Na}_{2} \mathrm{O} \\
\%\end{array}$ & $\begin{array}{c}{ }^{\mathrm{c}} \mathrm{MgO} \\
\%\end{array}$ & $\underset{\%}{\mathrm{TiO}_{2}}$ & $\begin{array}{c}{ }^{\mathrm{c}} \mathrm{CaO}^{\mathrm{c}} \\
{ }_{\%}\end{array}$ & $\begin{array}{c}{ }^{\mathrm{c}} \mathrm{P}_{2} \mathrm{O}_{5}{ }^{\mathrm{d}}{ }^{\mathrm{d}} \\
{ }^{4}\end{array}$ & $\begin{array}{c}{ }^{\mathrm{d}} \text { Total Se }^{\mathrm{d}} \mathrm{g} \\
\mathrm{g}\end{array}$ & $\begin{array}{c}{ }^{1} \text { Total As } \\
\text { ng/g/g }\end{array}$ & $\begin{array}{l}{ }^{\mathrm{d}} \mathrm{Se}(\mathrm{IV}) \\
\mathrm{ng} / \mathrm{g}\end{array}$ \\
\hline 25 & 5.75 & 63.87 & 26.68 & 0.83 & 0.22 & 1.02 & 1.54 & 0.22 & 0.08 & 10.30 & 6296 & 6.67 \\
\hline 60 & 2.48 & 81.05 & 15.28 & 0.00 & 0.07 & 0.48 & 0.86 & 0.22 & 0.10 & 93.20 & 4200 & 0.00 \\
\hline 61 & 2.47 & 79.51 & 15.70 & 0.87 & 0.07 & 0.43 & 0.79 & 0.23 & 0.12 & 17.20 & 2900 & 4.52 \\
\hline 125 & 3.14 & 71.03 & 24.02 & 0.00 & 0.00 & 0.86 & 1.41 & 0.00 & 0.07 & 35.93 & 6017 & 0.00 \\
\hline 157 & 2.59 & 79.66 & 17.50 & 0.00 & 0.00 & 0.66 & 0.37 & 0.00 & 0.10 & 3.900 & 2550 & 1.43 \\
\hline 181 & 4.97 & 68.08 & 22.16 & 2.10 & 0.01 & 1.61 & 1.23 & 0.03 & 0.07 & 1.490 & 6909 & 0.00 \\
\hline 211 & 3.59 & 73.34 & 20.03 & 1.28 & 0.00 & 1.06 & 0.88 & 0.04 & 0.12 & 34.33 & 2722 & 1.48 \\
\hline 241 & 3.88 & 70.40 & 21.41 & 1.57 & 0.00 & 1.48 & 1.46 & 0.01 & 0.09 & 168.7 & 6676 & 64.0 \\
\hline 278 & 4.72 & 64.12 & 21.90 & 6.02 & 0.01 & 1.82 & 1.29 & 0.14 & 0.13 & 26.00 & 2471 & 4.12 \\
\hline 290 & 5.13 & 62.85 & 23.66 & 4.91 & 0.12 & 2.18 & 1.16 & 0.09 & 0.12 & 47.53 & 3887 & 1.90 \\
\hline 299 & 5.44 & 65.29 & 25.14 & 1.44 & 0.07 & 1.33 & 1.29 & 0.00 & 0.07 & 63.07 & 7510 & 0.00 \\
\hline 305 & 4.19 & 68.55 & 21.24 & 3.01 & 0.00 & 1.75 & 1.32 & 0.03 & 0.11 & 8.270 & 5329 & 7.72 \\
\hline 337 & 2.69 & 79.48 & 16.37 & 0.63 & 0.00 & 0.78 & 0.14 & 0.26 & 0.10 & 44.20 & 2677 & 24.0 \\
\hline 369 & 6.10 & 54.00 & 24.36 & 11.8 & 0.02 & 1.86 & 1.49 & 0.28 & 0.13 & 134.8 & 7305 & 21.5 \\
\hline 372 & 4.84 & 64.71 & 22.00 & 4.75 & 0.00 & 2.36 & 1.44 & 0.05 & 0.09 & 63.33 & 5702 & 1.96 \\
\hline 397 & 3.17 & 75.03 & 19.76 & 0.00 & 0.00 & 0.95 & 1.40 & 0.05 & 0.13 & 47.25 & 2262 & 1.60 \\
\hline 404 & 4.90 & 64.84 & 22.50 & 4.55 & 0.00 & 1.99 & 1.28 & 0.04 & 0.11 & 58.07 & 3812 & 0.00 \\
\hline 414 & 3.32 & 80.45 & 16.90 & 0.00 & 0.00 & 0.57 & 0.32 & 0.00 & 0.11 & 63.97 & 3506 & 0.00 \\
\hline 432 & 3.16 & 76.11 & 19.00 & 0.44 & 0.00 & 0.62 & 0.44 & 0.52 & 0.10 & 25.60 & 1949 & 0.00 \\
\hline 448 & 3.02 & 76.73 & 14.73 & 2.70 & 0.00 & 1.22 & 0.59 & 1.22 & 0.12 & 17.05 & 3178 & 0.00 \\
\hline 479 & 2.67 & 79.12 & 17.13 & 0.72 & 0.00 & 0.56 & 0.03 & 0.16 & 0.10 & 23.20 & 1958 & 0.00 \\
\hline 482 & 5.75 & 56.77 & 18.68 & 15.1 & 0.01 & 2.33 & 0.89 & 0.43 & 0.13 & 8.450 & 6457 & 5.30 \\
\hline 486 & 3.49 & 73.69 & 18.22 & 1.03 & 0.94 & 1.25 & 1.33 & 0.13 & 0.17 & 5.700 & 3625 & 1.13 \\
\hline 505 & 2.81 & 78.26 & 15.43 & 1.04 & 0.63 & 0.91 & 0.50 & 0.57 & 0.11 & 10.10 & 2895 & 0.95 \\
\hline 519 & 3.03 & 76.27 & 16.20 & 1.67 & 0.72 & 1.06 & 0.82 & 0.36 & 0.13 & 5.200 & 4189 & 0.90 \\
\hline 571 & 4.91 & 62.25 & 23.95 & 5.17 & 0.05 & 2.15 & 1.34 & 0.04 & 0.08 & 387.0 & 5800 & 0.00 \\
\hline 572 & 4.36 & 63.96 & 22.55 & 5.56 & 0.05 & 2.28 & 1.35 & 0.04 & 0.10 & 236.6 & 4210 & 82.1 \\
\hline 578 & 4.63 & 63.23 & 22.49 & 5.80 & 0.07 & 2.32 & 1.46 & 0.07 & 0.12 & 10.20 & 4236 & 6.40 \\
\hline 581 & 3.28 & 65.07 & 19.88 & 8.53 & 0.00 & 1.73 & 1.23 & 0.21 & 0.16 & 5.900 & 2330 & 1.90 \\
\hline 639 & 2.73 & 76.45 & 16.40 & 1.45 & 1.48 & 0.94 & 0.39 & 0.30 & 0.12 & 3.600 & 5267 & 0.90 \\
\hline 677 & 5.12 & 62.13 & 22.13 & 6.57 & 0.10 & 2.42 & 1.43 & 0.00 & 0.09 & 15.70 & 5036 & 10.4 \\
\hline 697 & 4.60 & 60.77 & 22.12 & 7.98 & 0.06 & 2.22 & 1.52 & 0.11 & 0.13 & 66.60 & 2790 & 9.85 \\
\hline 699 & 5.98 & 62.24 & 24.31 & 4.14 & 0.22 & 1.99 & 1.37 & 0.00 & 0.06 & 121.9 & 6392 & 115 \\
\hline 700 & 5.52 & 63.83 & 23.28 & 4.16 & 0.19 & 1.97 & 1.27 & 0.00 & 0.06 & 228.8 & 6572 & 92.8 \\
\hline 701 & 5.73 & 62.37 & 23.41 & 5.02 & 0.25 & 2.12 & 1.24 & 0.00 & 0.07 & 239.0 & 5294 & 122 \\
\hline 719 & 3.09 & 75.01 & 16.75 & 1.37 & 1.67 & 1.13 & 0.68 & 0.43 & 0.13 & 7.270 & 3385 & 6.23 \\
\hline 764 & 4.57 & 62.83 & 20.77 & 7.07 & 0.56 & 2.28 & 1.35 & 0.26 & 0.15 & 12.90 & 6469 & 10.3 \\
\hline 769 & 5.12 & 58.73 & 21.34 & 10.0 & 0.19 & 2.51 & 1.44 & 0.58 & 0.16 & 21.30 & 7320 & 18.4 \\
\hline 771 & 2.75 & 68.08 & 18.93 & 5.46 & 1.13 & 1.76 & 1.15 & 0.73 & 0.18 & 10.30 & 4331 & 8.43 \\
\hline 776 & 4.68 & 60.93 & 22.07 & 7.64 & 0.23 & 2.33 & 1.59 & 0.45 & 0.17 & 18.03 & 4296 & 15.3 \\
\hline 778 & 4.97 & 61.54 & 21.15 & 8.19 & 0.10 & 2.34 & 1.35 & 0.33 & 0.15 & 19.43 & 6234 & 19.2 \\
\hline 791 & 3.62 & 70.49 & 20.81 & 1.98 & 0.02 & 1.48 & 1.50 & 0.14 & 0.21 & 15.37 & 3560 & 9.13 \\
\hline 818 & 3.01 & 72.90 & 17.93 & 2.36 & 1.77 & 1.20 & 0.61 & 0.33 & 0.13 & 13.93 & 3807 & 9.90 \\
\hline 831 & 4.75 & 64.03 & 21.90 & 5.35 & 0.15 & 2.23 & 1.57 & 0.07 & 0.15 & 15.67 & 4783 & 15.1 \\
\hline 834 & 4.76 & 61.21 & 20.89 & 8.44 & 0.52 & 2.28 & 1.57 & 0.29 & 0.16 & 18.60 & 6552 & 13.9 \\
\hline 857 & 2.93 & 68.34 & 19.98 & 4.69 & 0.78 & 1.51 & 0.92 & 0.92 & 0.13 & 17.00 & 5292 & 9.63 \\
\hline 881 & 4.13 & 60.85 & 22.16 & 8.28 & 0.48 & 2.28 & 1.43 & 0.42 & 0.13 & 25.97 & 5328 & 3.46 \\
\hline
\end{tabular}

Table 18: ${ }^{\mathrm{c}}$ X-ray fluorescence (courtesy, WVGES ${ }^{7}$ ) and ${ }^{\mathrm{d}}$ Atomic absorption spectrometry data. 


\begin{tabular}{|c|c|c|c|c|c|c|c|c|}
\hline Variable & PC1 & PC2 & PC3 & PC4 & PC5 & PC6 & PC7 & PC8 \\
\hline Quartz & -0.329 & 0.046 & -0.031 & -0.066 & 0.084 & 0.108 & 0.137 & -0.078 \\
\hline K -Feldspar & -0.289 & 0.141 & 0.104 & -0.165 & -0.119 & 0.049 & 0.010 & 0.376 \\
\hline Plagioclase & -0.078 & -0.443 & -0.344 & 0.264 & 0.122 & -0.218 & -0.083 & $\odot .082$ \\
\hline Illite & 0.320 & -0.051 & -0.028 & 0.111 & -0.139 & 0.181 & 0.053 & 0.170 \\
\hline Kaolinite & -0.001 & 0.218 & 0.376 & 0.500 & -0.241 & -0.549 & 0.037 & 0.033 \\
\hline Chlorite & $\odot .265$ & $-\odot . \odot \odot \odot$ & $\odot .0 \odot 4$ & -0.308 & 0.228 & -0.327 & -0.403 & -0.339 \\
\hline$\% \mathrm{~K} 20$ & 0.311 & 0.066 & 0.001 & 0.033 & -0.060 & 0.187 & -0.100 & 0.401 \\
\hline \% Si02 & -0.323 & 0.119 & -0.123 & -0.024 & 0.085 & 0.044 & 0.016 & -0.175 \\
\hline$\%$ Al203 & 0.289 & 0.152 & 0.059 & $\odot .327$ & 0.145 & -0.117 & 0.156 & 0.087 \\
\hline \% Fe203 & 0.241 & -0.253 & 0.206 & -0.233 & -0.294 & 0.021 & -0.167 & 0.234 \\
\hline$\% \mathrm{Na} 20$ & -0.091 & -0.419 & -0.376 & ๑. 222 & 0.121 & -0.238 & -0.080 & 0.225 \\
\hline$\% \mathrm{MgO}$ & 0.299 & -0.176 & 0.079 & -0.232 & 0.029 & -0.112 & -0.168 & -0.106 \\
\hline$\%$ Ti02 & 0.275 & -0.050 & 0.125 & 0.053 & 0.352 & 0.010 & 0.497 & -0.295 \\
\hline$\% \mathrm{CaO}$ & -0.101 & -0.363 & 0.085 & 0.015 & -0.663 & -0.026 & 0.124 & -0.426 \\
\hline \% P205 & -0.037 & -0.423 & ๑. 312 & -0.261 & 0.163 & $-\odot .097$ & $\odot .514$ & 0.206 \\
\hline Total Se & 0.146 & 0.270 & -0.395 & -0.197 & -0.228 & -0.271 & 0.202 & -0.065 \\
\hline Total As & 0.239 & $-\odot .071$ & -0.208 & 0.320 & -0.114 & $\odot .502$ & 0.054 & -0.222 \\
\hline $\mathrm{Se}(\mathrm{IV})$ & 0.157 & 0.167 & -0.447 & -0.252 & -0.214 & -0.206 & 0.375 & 0.145 \\
\hline Eigenvalue & 8.6095 & 2.8593 & 1.8580 & 1.1147 & ๑. 9099 & 0.8283 & ๑. 4919 & 0.3583 \\
\hline Proportion & 0.478 & 0.159 & 0.103 & 0.062 & $\odot .051$ & 0.046 & $\odot .027$ & $\odot .020$ \\
\hline Cumulative & 0.478 & 0.637 & 0.740 & $\odot .802$ & $\odot .853$ & $\odot .899$ & 0.926 & 0.946 \\
\hline
\end{tabular}

Table 19: Variable loadings to the first eight PCs and their respective eigenvalues. 


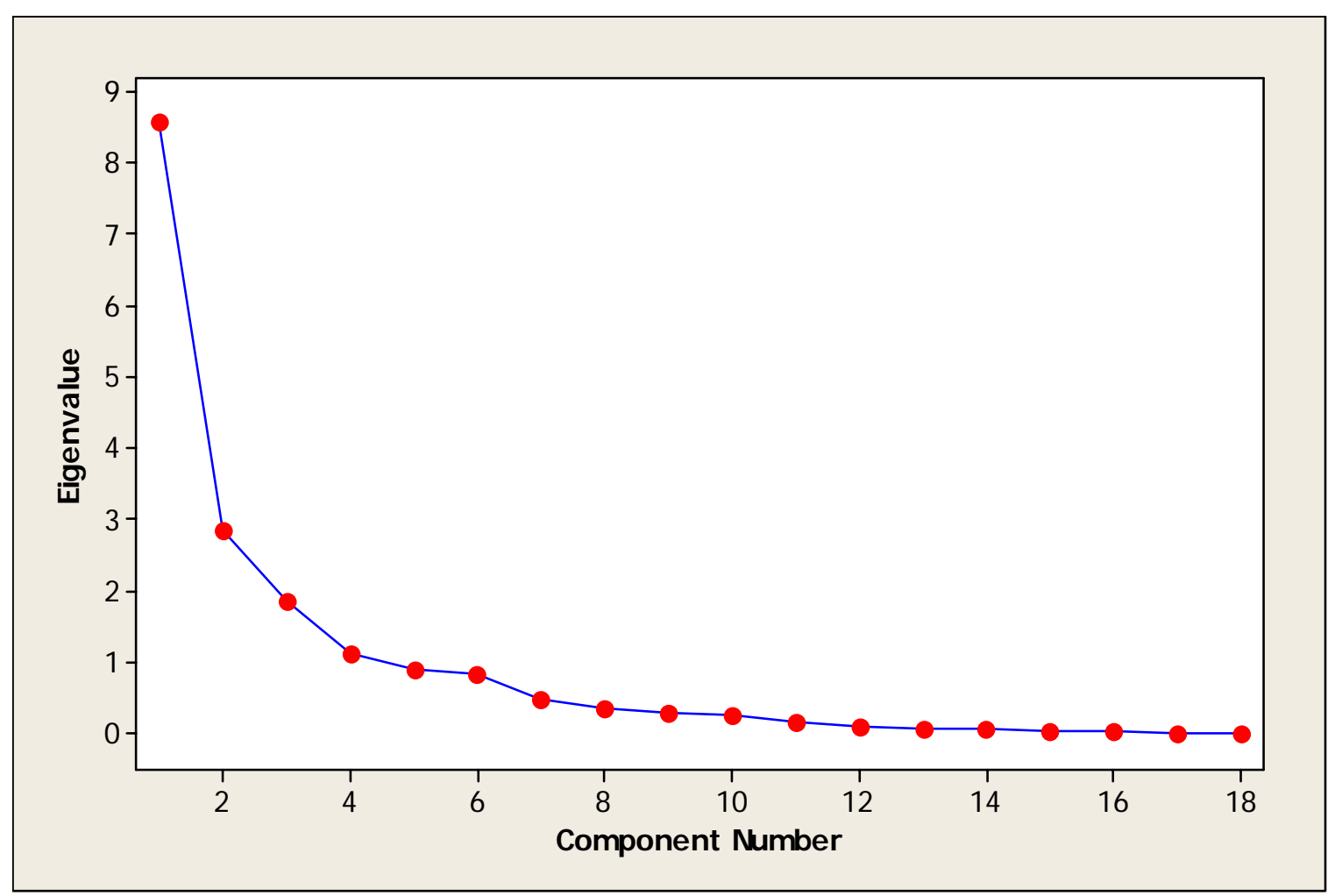

Figure 51: A scree plot showing all the PCs and their corresponding eigenvalues. 
and plagioclase feldspar (Albite and Anorthite). Anorthite $\left(\mathrm{CaAl}_{2} \mathrm{Si}_{2} \mathrm{O}_{8}\right)$ and albite $\left(\mathrm{NaAlSi}_{3} \mathrm{O}_{8}\right)$ are $\mathrm{Ca}$ and Na plagioclases. ${ }^{139}$ Cluster A sandstones contain orthoclase (Kfeldspar) and quartz while cluster B sandstones are associated with plagioclase $(\mathrm{Na} / \mathrm{Ca}$ feldspar). The two clusters (A and B), composed of different mineral compositions, both originated from sandstones. Figures 53 (2-dimensional score plot) and 54 (biplot) clearly show the distinct sandstone clusters.

Samples $60,61,157,337,414,432$ and 479 belong to the orthoclase derived sandstone cluster while $448,486,505,519,639,719,771$ and 791 belong to the plagioclase derived sandstone cluster. It appears that there is a transition from orthoclase feldspar to plagioclase feldspar as the rocks are exposed to the earth's surface. Orthoclase derived sandstone samples were collected at depths closer to the surface whereas plagioclase sandstones were collected at depths of approximately 400 feet and lower. Generally, the sandstones have low amounts of both arsenic and selenium as shown in Table 18; however, selenium is released at faster rates from sandstones than claystones (Chapter 2). Although the concentration of selenium is low in sandstones, it is the most bioavailable (Chapter 2).

In Figure 52, cluster $\mathrm{C}$ is comprised of the solitary kaolinite, cluster D consists of illite, $14 \AA$ d spacing clays , arsenic, selenite and total selenium including oxides of Al, $\mathrm{Ti}, \mathrm{K}, \mathrm{Fe}$ and $\mathrm{Mg}$. The information suggests that most elements (exception of $\mathrm{Ca}, \mathrm{P}, \mathrm{Na}$ and partly K) are all associated with $14 \AA$ d spacing clays and illite. As shown in Figures 52-54, claystones, shales and siltstones are all associated with 14 Ád spacing clays and illite and to a lesser extent kaolinite. Samples 571, 572, 699, 700 and 701 are claystones and had the highest amounts of selenium and $14 \AA$ d spacing clays as shown in Tables 17 


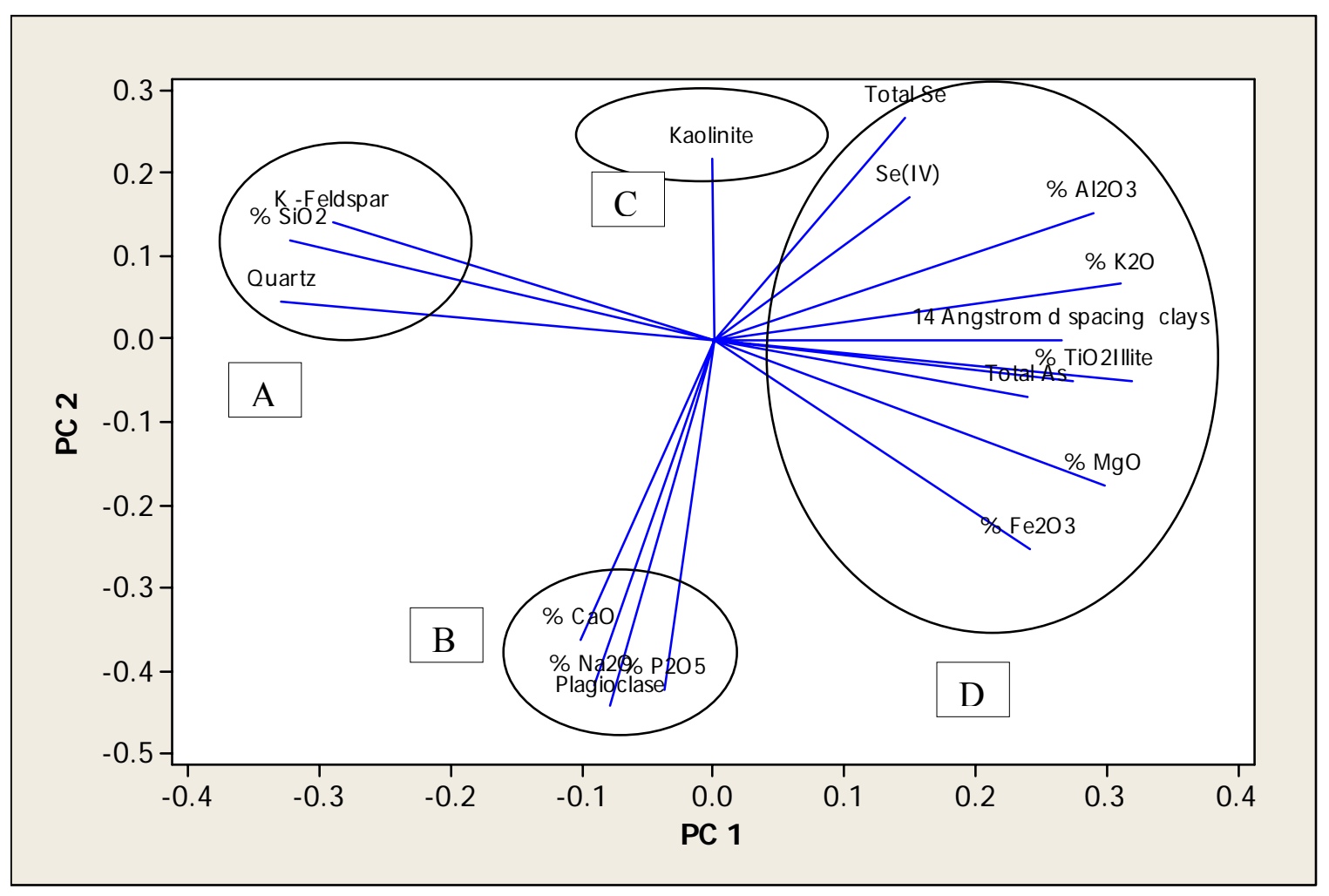

Figure 52: Variable loading plot for PC 1 vs. PC 2. 


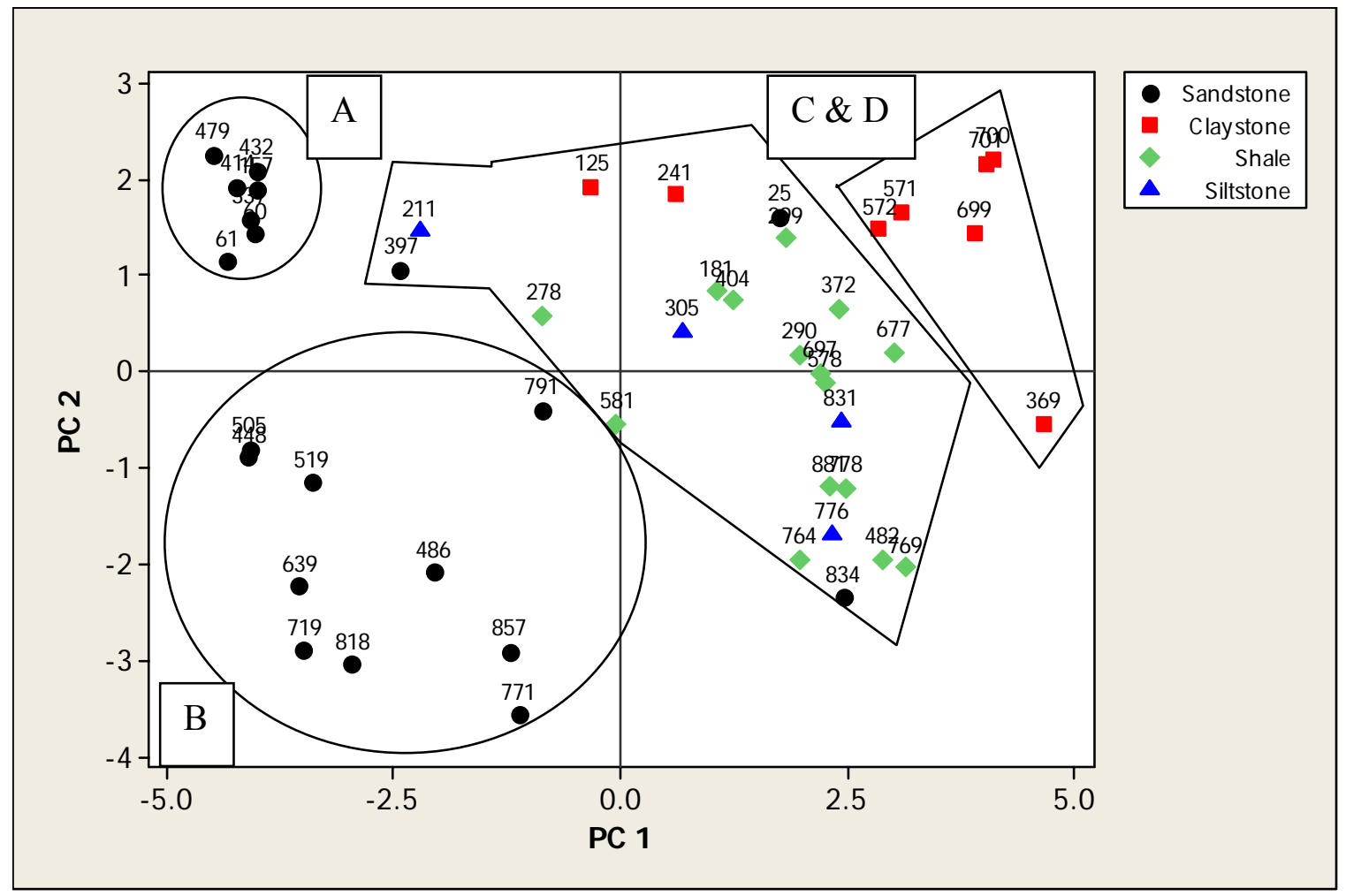

Figure 53: A two dimensional sample score plot (total PC variance $63.7 \%$ ) 


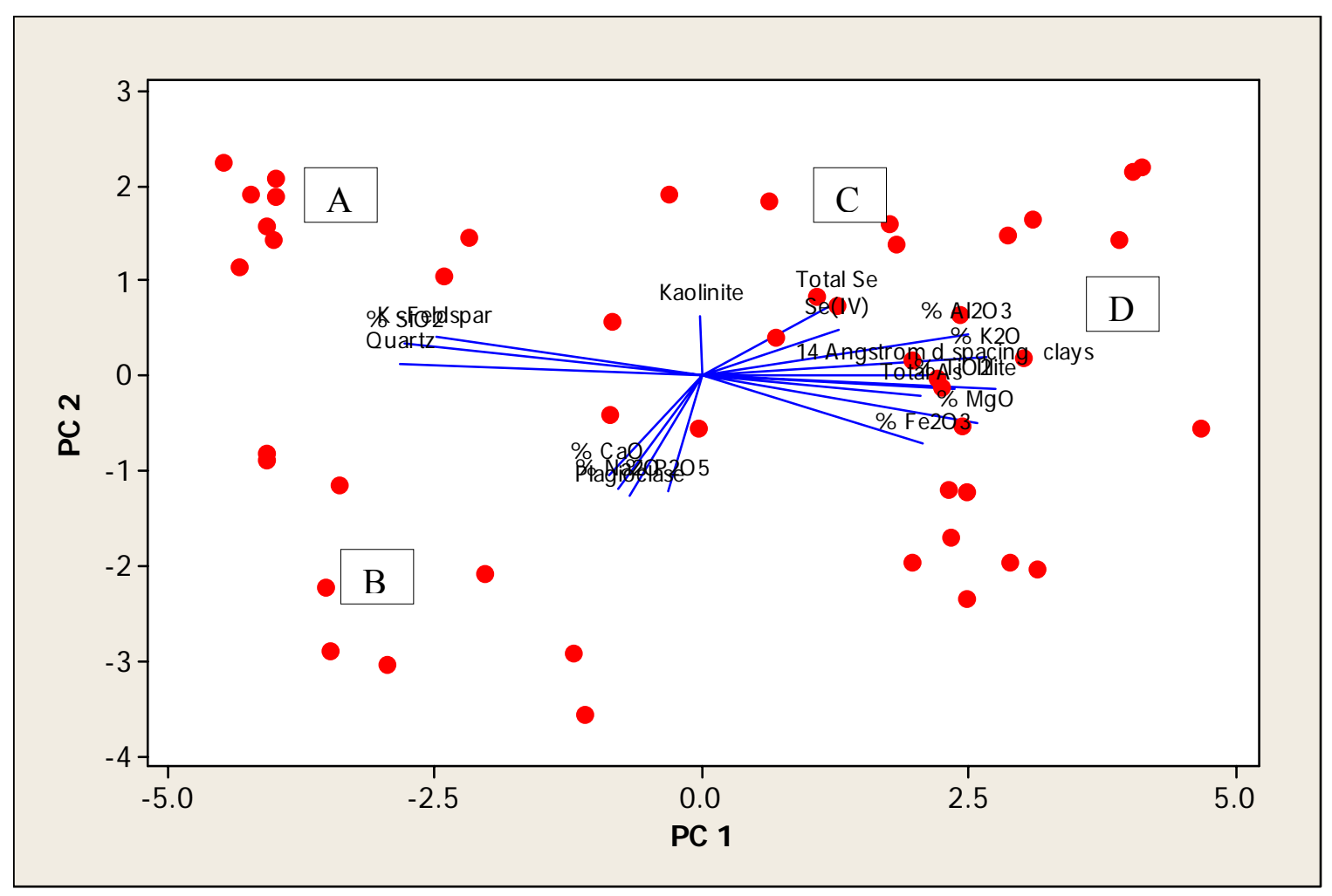

Figure 54: A biplot showing the relationship between objects (samples) and variable loadings 


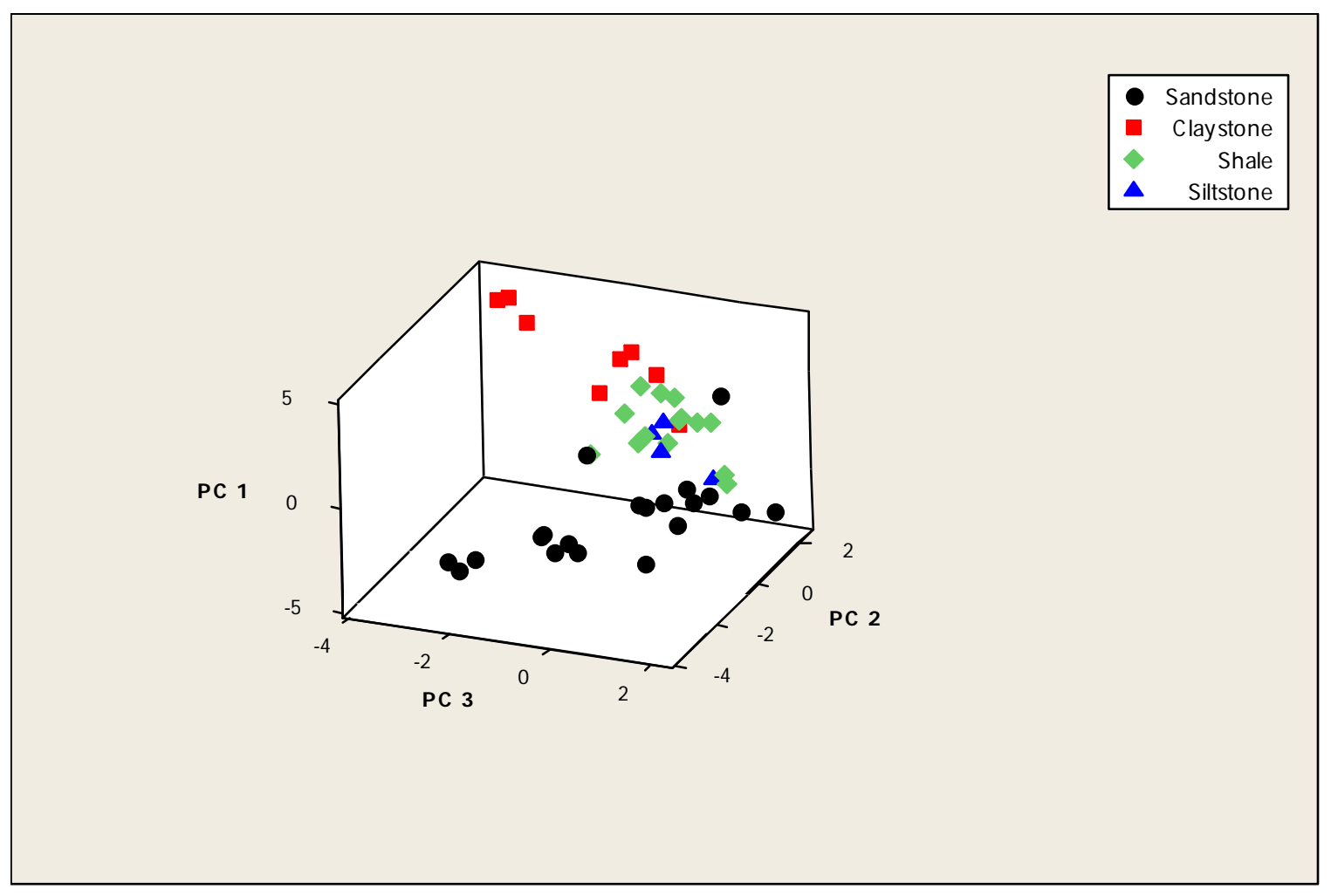

Figure 55: A three dimensional score plot (total PC variance 74.0\%) 
and 18. These five samples belong to one cluster as illustrated in Figures 52-54. The remainder of the claystones is included together with shales and siltstones in cluster B. The claystones, siltstones and shales generally have more selenium and arsenic compared to sandstones. A three-dimensional plot of PC 1, PC 2 and PC 3 shown in Figure 55, further accentuates the differences between rock samples.

\section{Secondary PCA analysis}

The data identified clay minerals and elements $\mathrm{Al}, \mathrm{Ti}, \mathrm{K}, \mathrm{Fe}$ and $\mathrm{Mg}$ correlated closely with both selenium and arsenic concentrations because they all appeared in one cluster as shown in Figure 56. In order to identify the relationships between clay minerals with arsenic and selenium, a secondary principal component analysis was performed on the most important variables: illite, 14 Á d spacing clays, kaolinite, selenium and arsenic. Before the application of a secondary PCA, the individual 14 Á d spacing clays, kaolinite and illite concentrations were transformed into fractions that indicate their contribution to the total clay content $(\%$ illite $+\%$ kaolinite $+\% 14$ Á d spacing clays $)$ in each sample. The kaolinite fraction was mapped into \% kaolinite/ (total clay content) in all samples. The \% illite and \% 14 Á d spacing clays were also converted into their fractional contribution to the total clay content. The loading plot of the secondary PCA is shown in Figure 56 and the remainder of the results are given in Appendix 1D.

PC1a describes illite composition and PC 2a represents 14 Á d spacing clays composition. As shown in Figure 56 the $14 \AA$ A spacing clays fractional component clustered together with selenium concentrations whereas the arsenic concentration clustered with the illite clay component. Kaolinite was negatively correlated with either arsenic or selenium concentrations as shown by the euclidean obtuse angles separating 
them. Therefore, kaolinite is not considered to be a critical clay component in rock minerals when considering selenium and arsenic pollution because no positive correlation was found between kaolinite and either selenium or arsenic (or other elements as shown in Figures 52-54).

\section{Scatter and Contour plots}

Pearson correlations are applicable to normally distributed data where there is a linear relationship between variables. ${ }^{140}$ The data were initially standardized to ascertain normal distribution before the calculation of correlation coefficients.

\section{Correlations with selenium}

Although there is a non-linear global relationship between selenium and $14 \AA \hat{d}$ spacing clays as shown in Figures 56-57, it appears that the distribution of selenium in 14 $\AA$ d spacing clays is dependent on rock lithology. As shown in Figure 57, the correlation coefficient between selenium and $14 \AA$ d spacing clays in claystones $(r=0.84, p \leq 0.01, n$ =7) was the highest compared to shales $(r=0.64, \mathrm{p} \leq 0.05, \mathrm{n}=18)$, sandstones $(\mathrm{r}=$ $0.56, \mathrm{p} \leq 0.01, \mathrm{n}=19)$ and siltstones $(\mathrm{r}=0.76, \mathrm{p} \leq 0.24, \mathrm{n}=4)$. The contour plot between selenite, selenate and $14 \AA$ clays shown in Figure 58 suggested that samples

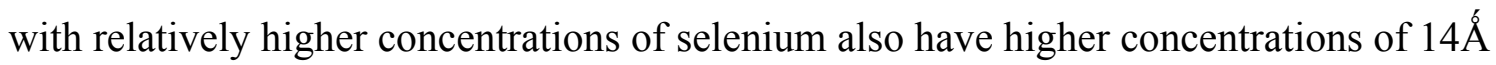
clays. Negative correlation coefficients were obtained for selenium-plagioclase $(r=$ $0.11, \mathrm{p} \leq 0.13, \mathrm{n}=48)$ and selenium-orthoclase $(\mathrm{r}=-0.33, \mathrm{p} \leq 0.02, \mathrm{n}=48)$. The correlation coefficients given in the scatter plot shown in Figure 59 for selenium and kaolinite were in claystones $(\mathrm{r}=-0.56, \mathrm{p} \leq 0.01, \mathrm{n}=7)$, shales $(\mathrm{r}=-0.21, \mathrm{p} \leq 0.01, \mathrm{n}=$ 18), sandstones $(\mathrm{r}=-0.58, \mathrm{p} \leq 0.01, \mathrm{n}=19)$ and siltstones $(\mathrm{r}=-0.89, \mathrm{p} \leq 0.24, \mathrm{n}=4)$. Overally there was a global negative correlation coefficient between selenium and 


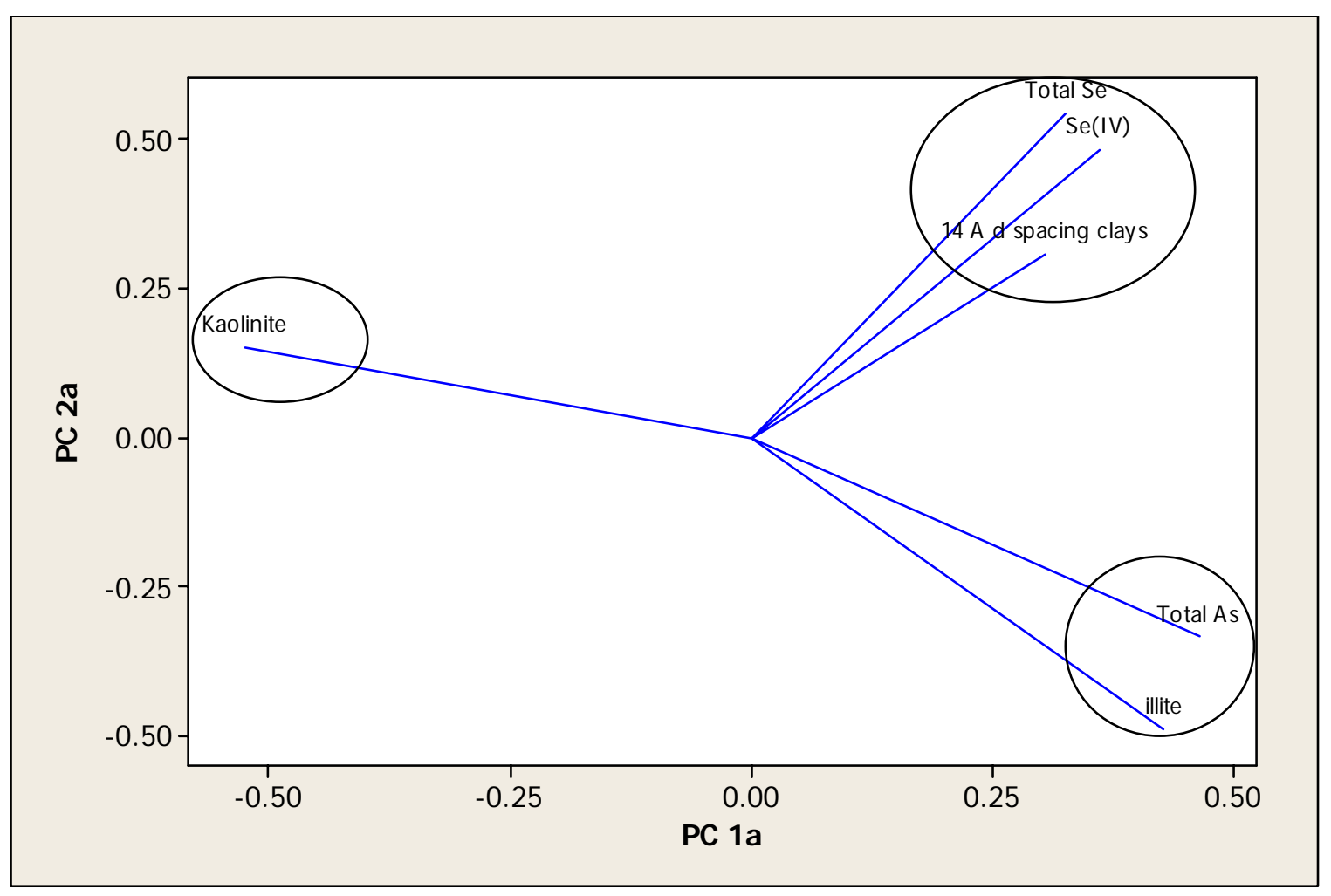

Figure 56: Secondary PCA loading plot for mineral inclusions 


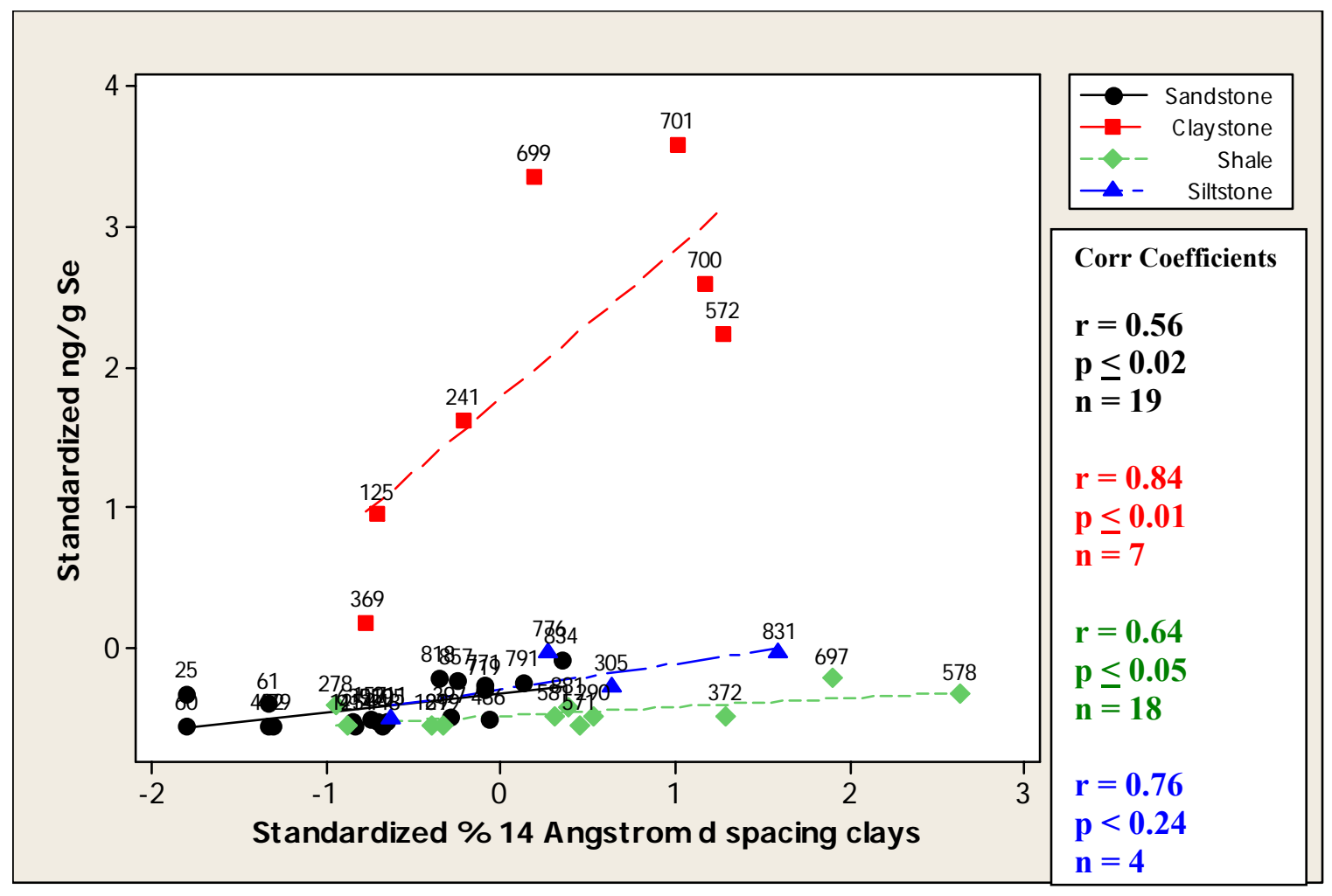

Figure 57: A two dimensional scatter plot between standardized values for $\mathrm{ng} / \mathrm{g}$ selenium and 14-Á-d-spacing clay concentrations 


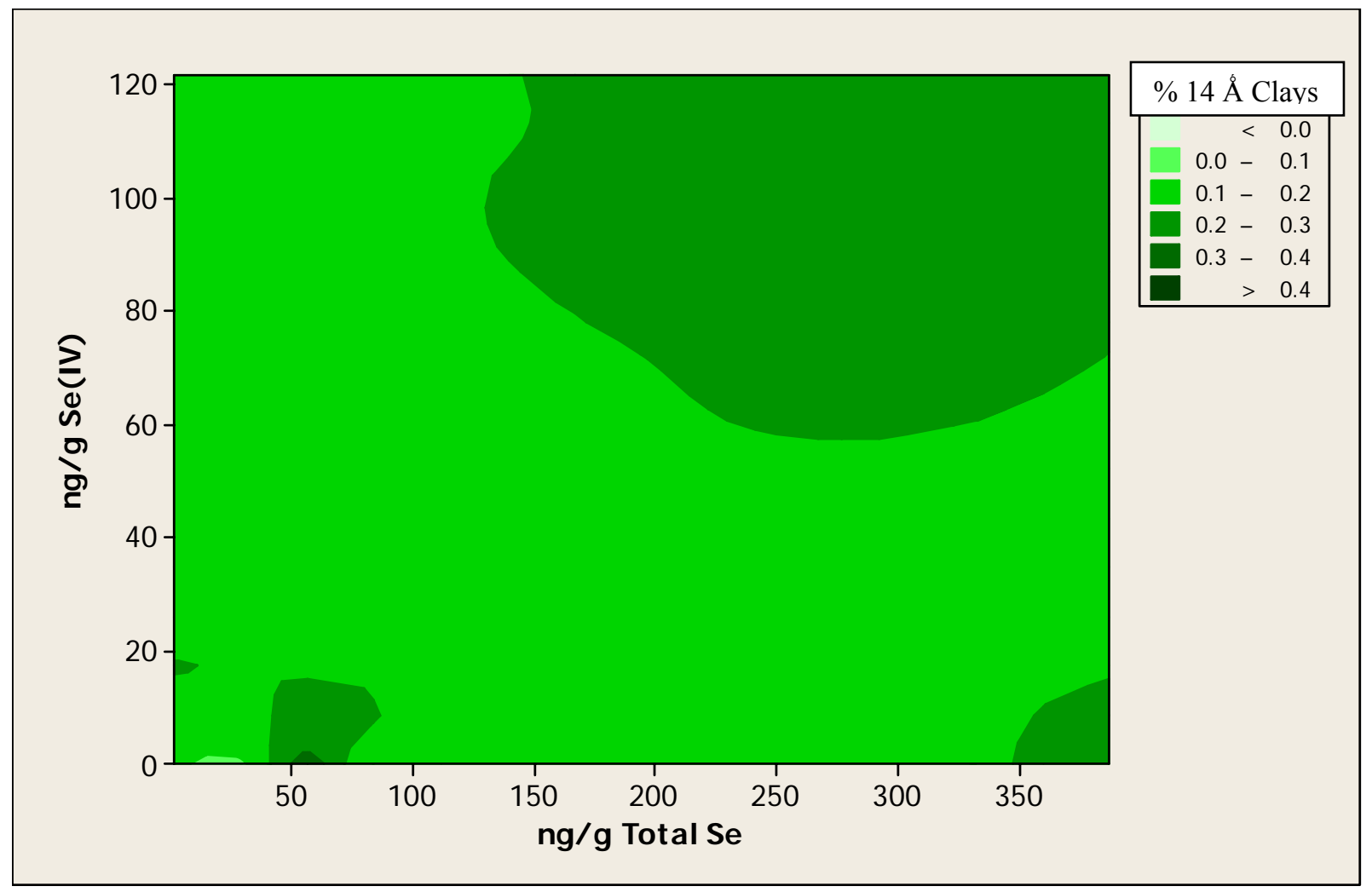

Figure 58: A contour plot between total selenium, selenite and 14 Á d spacing clay concentrations. 


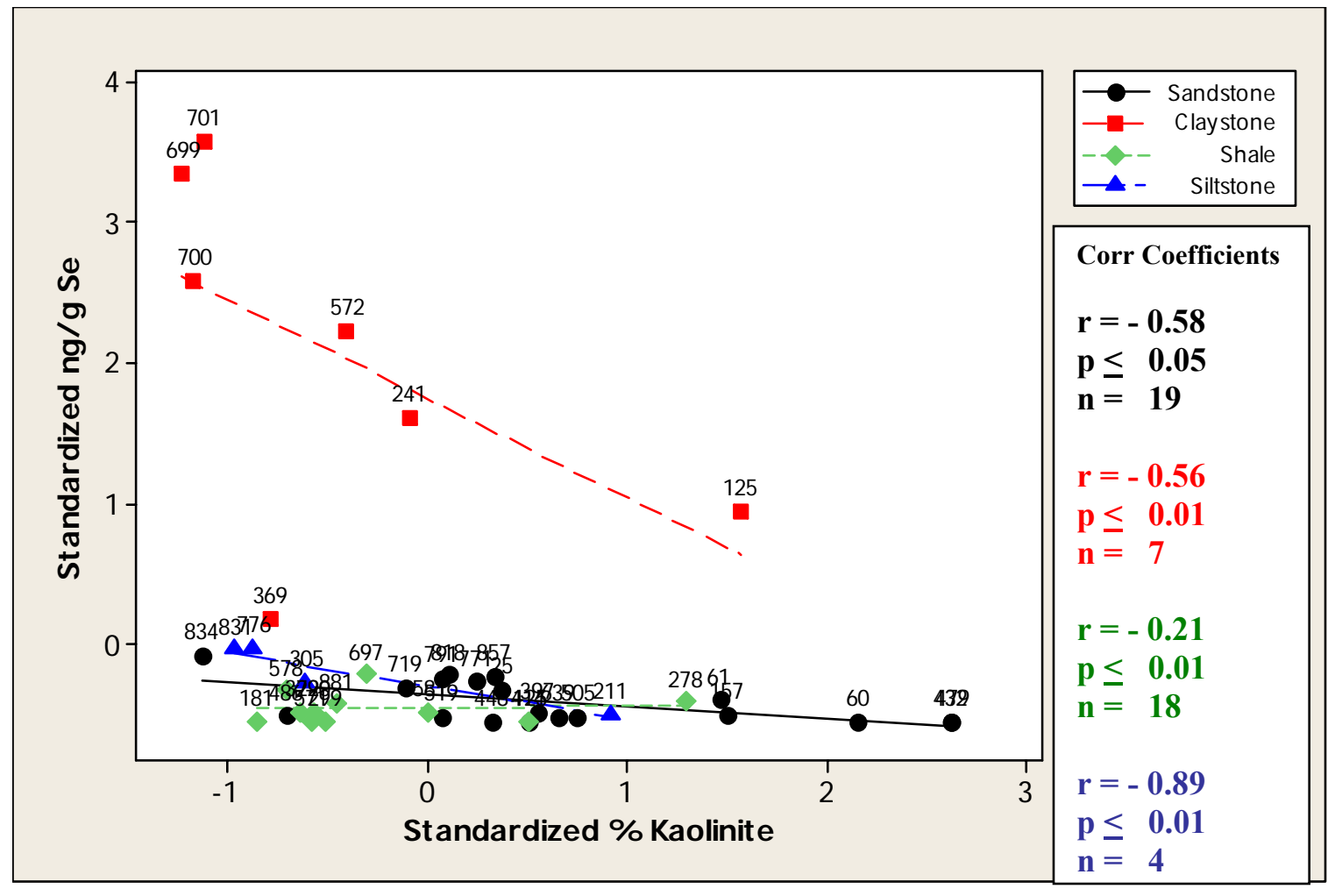

Figure 59: A two dimensional scatter plot between standardized values for $\mathrm{ng} / \mathrm{g}$ selenium and $\%$ kaolinite. 


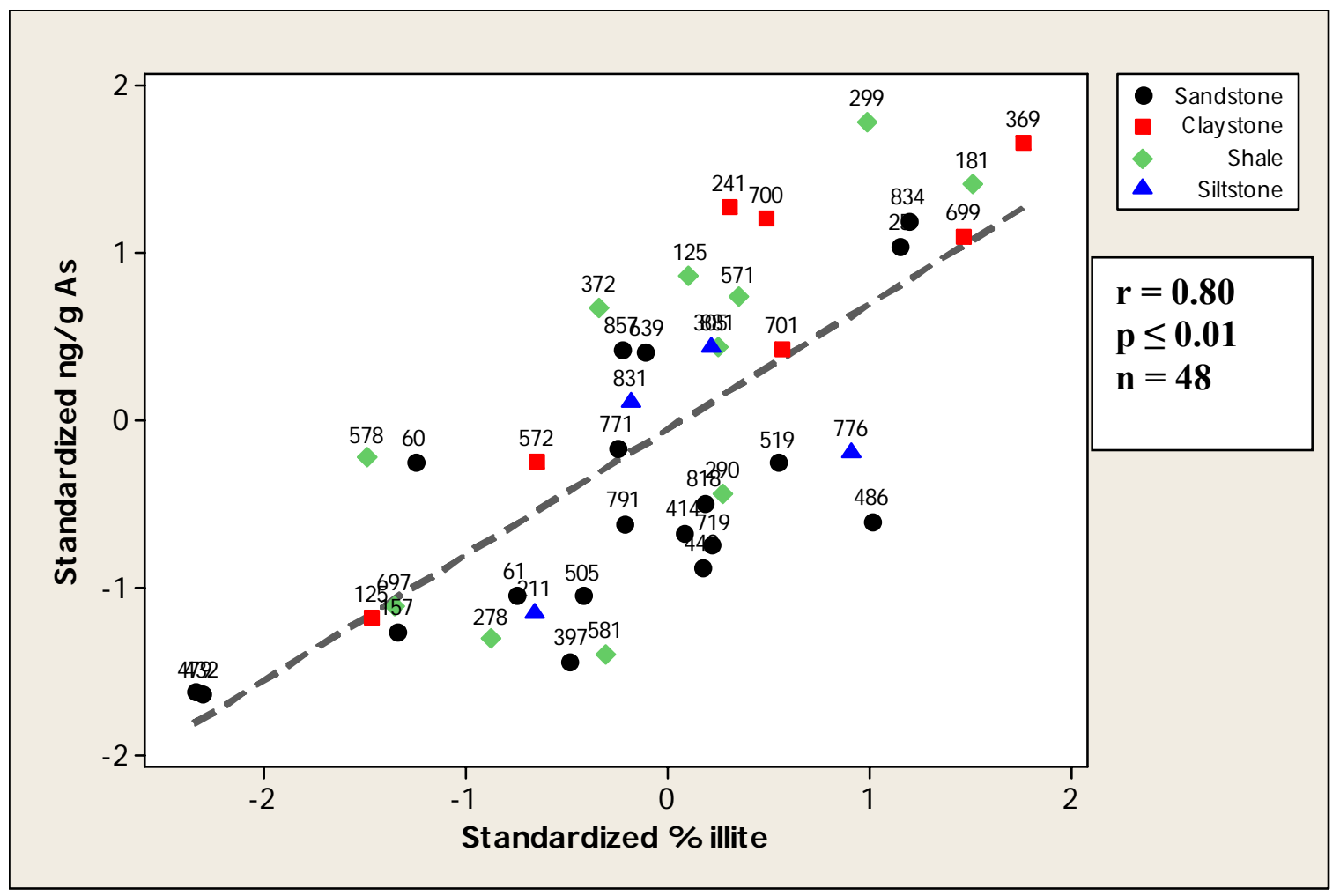

Figure 60: A two dimensional scatter plot between standardized values for $\mathrm{ng} / \mathrm{g}$ arsenic and $\%$ illite 


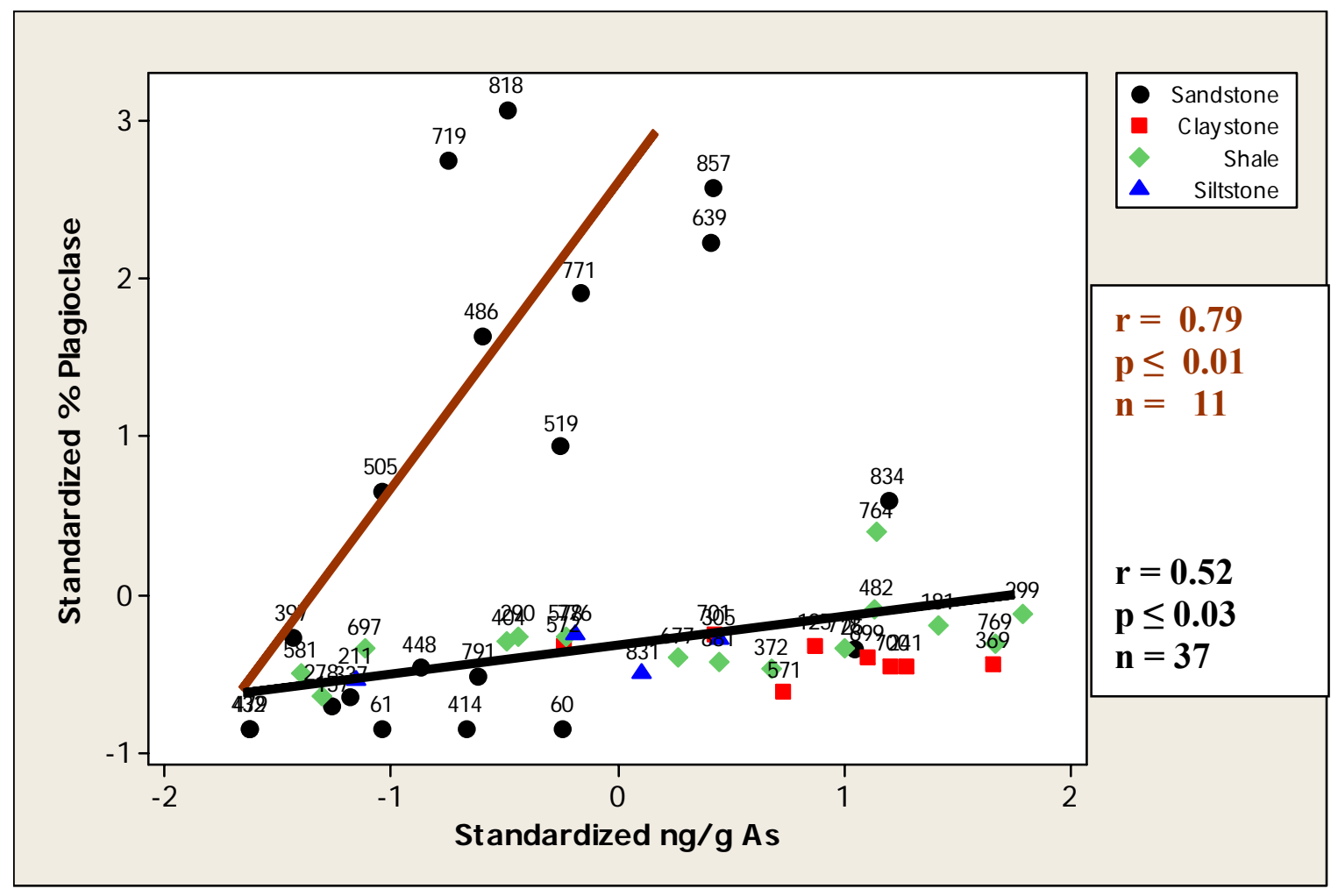

Figure 61: A two dimensional scatter plot between standardized values for $\mathrm{ng} / \mathrm{g}$ arsenic and $\%$ plagioclase 


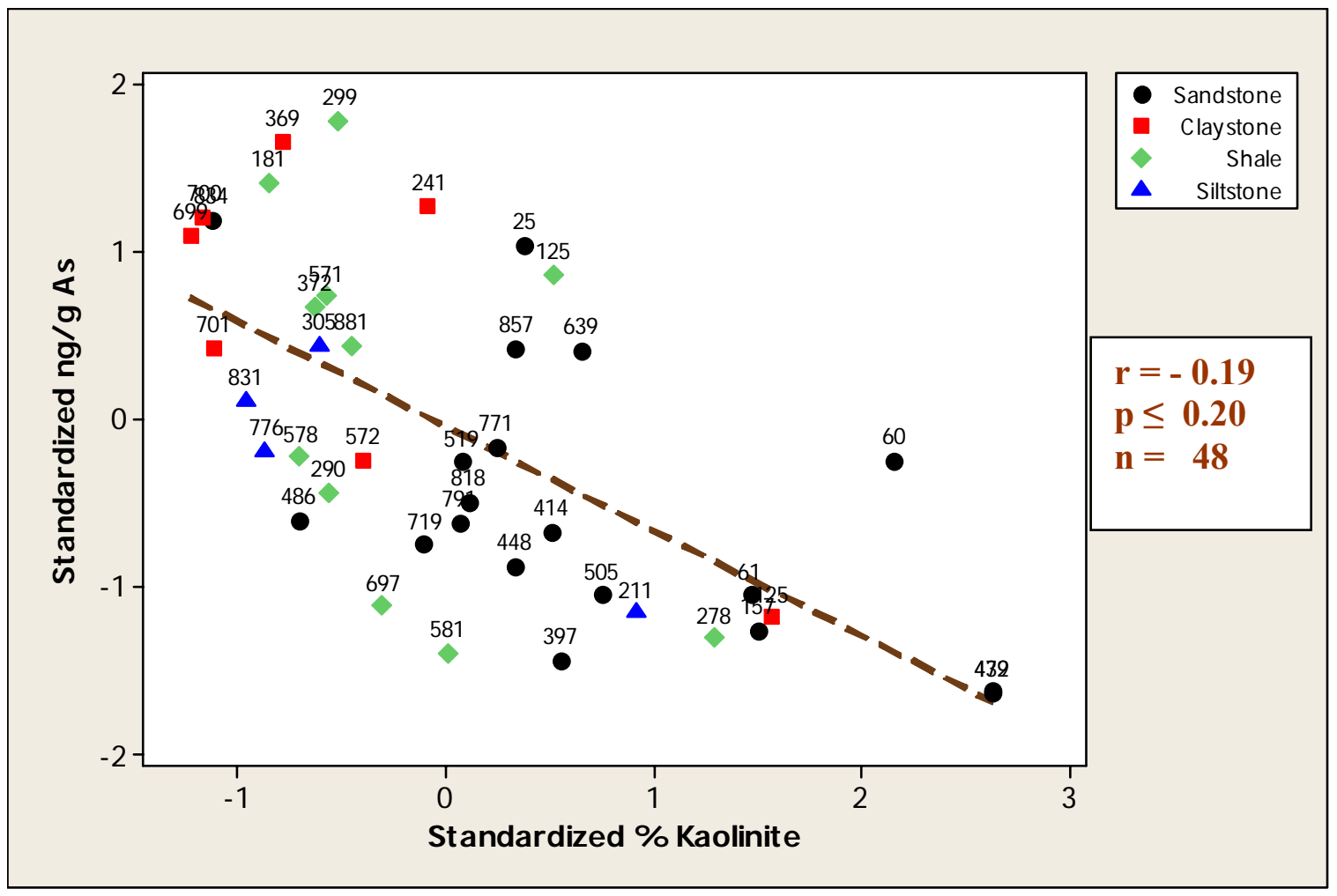

Figure 62: A two dimensional scatter plot between standardized values for $\mathrm{ng} / \mathrm{g}$ arsenic and $\%$ kaolinite 
kaolinite.

Total selenium concentrations had the following moderate correlations with $\mathrm{K}_{2} \mathrm{O}$ $(\mathrm{r}=0.379, \mathrm{p} \leq 0.009, \mathrm{n}=48), \mathrm{Al}_{2} \mathrm{O}_{3}(\mathrm{r}=0.370, \mathrm{p} \leq 0.011, \mathrm{n}=48), \mathrm{MgO}(\mathrm{r}=0.231, \mathrm{p} \leq$ $0.118, \mathrm{n}=48), \mathrm{TiO}_{2}(\mathrm{r}=0.187, \mathrm{p} \leq 0.209, \mathrm{n}=48), \mathrm{As}(0.290, \mathrm{p} \leq 0.048, \mathrm{n}=48)$ and $\mathrm{Fe}_{2} \mathrm{O}_{3}(\mathrm{r}=0.067, \mathrm{p} \leq 0.05, \mathrm{n}=48)$. The very low positive correlation coefficient between $\mathrm{Fe}_{2} \mathrm{O}_{3}$ and total selenium indicate remote chances on the presence of ferrosellite $\left(\mathrm{FeSe}_{2}\right.$ ) as reported to be the major selenite constituent in the US western phosphate rocks.${ }^{137}$ Other workers have identified no correlation between sulfur and selenium ${ }^{141}$ giving more evidence that selenium is not associated with $\mathrm{Fe}$ in pyrite or pyrrohotite. The negative correlations between total selenium with kaolinite, quartz, orthoclase and plagioclase indicate the absence of selenium in these rocks.

\section{Correlations with arsenic}

Positive correlations for arsenic with illite $(\mathrm{r}=0.80, \mathrm{p} \leq 0.01, \mathrm{n}=48)$ and with 14 Á d spacing clays $(\mathrm{r}=0.306, \mathrm{p} \leq 0.036, \mathrm{n}=48)$ were obtained as shown in Figure 60 . Arsenic from plagioclase-derived minerals had higher correlation with plagioclase $(\mathrm{r}=$ $0.79, \mathrm{p} \leq 0.01, \mathrm{n}=11)$ compared to non-plagioclase derived minerals $(\mathrm{r}=0.52, \mathrm{p} \leq 0.02$ $\mathrm{n}=37$ ) as shown in Figure 61. Arsenic concentrations had negative correlations with kaolinite $(r=-0.191, p \leq 0.20, n=48)$, as shown in Figure 62, and with orthoclase $(r=$ -

$0.70, \mathrm{p} \leq 0.01, \mathrm{n}=48)$. There were moderate correlations with $\mathrm{MgO}(\mathrm{r}=0.497, \mathrm{p} \leq 0.001$, $\mathrm{n}=48), \mathrm{Fe}_{2} \mathrm{O}_{3}(\mathrm{r}=0.410, \mathrm{p} \leq 0.001, \mathrm{n}=48), \mathrm{Al}_{2} \mathrm{O}_{3}(\mathrm{r}=0.571 \mathrm{p} \leq 0.001, \mathrm{n}=48), \mathrm{K}_{2} \mathrm{O}(\mathrm{r}$ $=0.661, \mathrm{p} \leq 0.001, \mathrm{n}=48)$ and $\mathrm{TiO}_{2}(\mathrm{r}=0.530, \mathrm{p} \leq 0.001, \mathrm{n}=48)$. 


\section{Location of selenium and arsenic in the mineral lattice \\ Interlayer position}

The presence of trace elements in clay minerals depends on the nature and type of clay. Illite and $14 \AA$ d spacing clays have been shown to have most of the selenium and arsenic compared to kaolinite. Kaolinite had negative correlations with claystoneselenium. As outlined in the previous section, positive correlations existed for $14 \AA$ d spacing clays and illite. The data suggest that kaolinite does not contain much selenium and arsenic compared to illite and $14 \AA$ d spacing clays; in fact, the negative correlation implies an inverse relationship.

The presence of selenium and arsenic in illite and $14 \AA$ d spacing clays implies that there could be a link between the microscopic structure of clays and elemental concentration. Kaolinite does not have an accessible interlayer but such an interlayer is present in illite and the $14 \AA$ d spacing clays.

The presence of accessible interlayer in illite and 14 Á d spacing clays is a clear distinguishing factor between the two classes of clays (1:1 and 2:1 types). This information points to the fact that arsenic and selenium could reside in the interlayer region of the illite and $14 \AA$ d spacing clays. Organic molecules containing arsenic and selenium could have been incorporated into the interlayer before lithification. It has been reported that dissolved organic molecules ${ }^{142}$ can sorb on the clay minerals and subsequently enter the interlayer spacing ${ }^{143,144}$ where intercalation and lithification can occur. 


\section{Ionic substitution}

The ionic radii for $\mathrm{K}^{+}, \mathrm{Al}^{3+}$ and $\mathrm{Mg}^{2+}$ and $\mathrm{Ti}^{4+}$ in crystal environments are 152 , 67.5 and $0.745 \mathrm{pm}$ respectively. ${ }^{145}$ The crystal radii for $\mathrm{Fe}^{2+}$ and $\mathrm{Fe}^{3+}$ are 0.75 and 0.69 pm for low spin and 0.92 and $0.79 \mathrm{pm}$ in high spin environments ${ }^{145}$, respectively. The crystal radii for selenium ions in are 184, 64 and 56 pm for Se (-II), Se (IV) and Se (VI) in solid states. Also the crystal radii for As (III) and As (V) are 72 and 60 pm respectively $^{145}$. Ions with similar charge and are about $15 \%$ of their size can replace one another through isomorphous substitution/inclusion (Goldschmidt rules of substitution $\left.{ }^{129}\right)$.

\section{Substitution in the interlayer}

Thus the ions $\mathrm{K}^{+}, \mathrm{Al}^{3+}$ and $\mathrm{Mg}^{2+}$ in clays can be replaced by other ions of comparable size and charge without distorting the crystal lattice. Therefore selenium ions could have been used in place of, or combined with $\mathrm{Al}^{3+}$ and $\mathrm{Mg}^{2+}$ during the formation of brucite and gibbsite in chlorite and in the uptake of $\mathrm{Mg}^{2+}$ in vermiculite because the ionic sizes of $\mathrm{Al}^{3+}$ and $\mathrm{Mg}^{2+}$ are close to those of Se (IV) and Se (VI). The radii for As (III) and As (V) are about $50 \%$ smaller than the size of $\mathrm{K}^{+}$in illite even though there was a close correlation between arsenic and illite.

\section{Substitution in the octahedral layers}

The ions $\mathrm{Al}^{3+}, \mathrm{Mg}^{2+}, \mathrm{Ti}^{4+}, \mathrm{Fe}^{2+}$ and $\mathrm{Fe}^{3+}$ found in the octahedral layer have ionic sizes that are within $15 \%$ the sizes of As (III), As (V), Se(IV) and Se(VI). Figure 62 shows two separate correlations between plagioclase and arsenic concentrations. The plagioclase derived sandstones had higher correlation $(\mathrm{r}=0.79, \mathrm{p} \leq 0.01, \mathrm{n}=11)$ 
with arsenic compared to the remainder of the samples $(\mathrm{r}=0.52, \mathrm{p} \leq 0.03, \mathrm{n}=37)$. This observation can be used to explain the observed high concentrations of arsenic in sandstones.

Thus As (III) and As (V) could have been included in the octahedral layer in place of the naturally present $\mathrm{Al}^{3+}, \mathrm{Mg}^{2+}, \mathrm{Ti}^{4+}, \mathrm{Fe}^{2+}$ and $\mathrm{Fe}^{3+}$ ions. Both selenium and arsenic ions can also occupy the vacant positions dioctahedral positions.

\section{Summary}

A two step principal component analysis is a powerful technique that orthogonally decomposes data matrix to quickly identify clustering of samples and variables that are closely related. Although kaolinitic clays are major constituents of river sediments with substantially high adsorption capacities, they do not constitute the most important clay fractions that harbor selenium and arsenic in rocks. The same applies for quartz and K-feldspars which correlated negatively with arsenic and selenium. On the other hand, plagioclase had a relatively high correlation with arsenic and this observation could be the reason why there were relatively high concentrations of arsenic in sandstones compared to selenium. The high correlation between illite and arsenic suggested that there are substantial amounts of arsenic that could be located in either the interlayer or the octahedral lattice. The illite and 14 Á d spacing clays are major constituents of claystones, shales and siltstones. The information obtained indicate that the interlayer in $14 \AA$ d spacing clays and illite could contain significant concentrations of selenium and arsenic, respectively. The entry of these elements in the interlayer could have occurred during intercalation and lithification stages. The low linear correlation 
coefficient between selenium and $14 \AA$ d spacing clays and the other elements is indicative of nonlinear relationship between selenium and 14 Á d spacing clays.

Above all the dissolution/weathering of $14 \AA$ d spacing clays is responsible for the accumulation of selenium in rivers and streams associated with MTR/VF mining. 


\section{Future studies}

There is need to use the stream water to study the ultrasound extraction kinetics of both selenium and arsenic. Affected streams both in flowing and stagnant water environments should be monitoring at least twice a year.

The sorption and redox kinetics on pure substances in the presence of humic acids need to be extended over to other clays such as montmorrillonite, chlorites, illites and other types of clays. The surface chemistry of the reacting species can be followed and studied by surface characterization techniques such as Electron Spectrometry for Chemical Analysis (ESCA).

More work is required on the speciation of arsenic using sequential extractions or ICP-MS techniques and the measurement of total organic carbon in both rocks and sediments.

There is need to create a database of all the core samples and then apply chemometrics to different lithologies in order to get direct correlations between large data sets of selenium in clays. This in turn can be used to identify the exact location of selenium and arsenic in the clays using a multitude of surface techniques such as ESCA, SIMS (secondary ion mass spectrometry) and AES (Auger electron spectroscopy). 


\section{Appendix 1A}

\section{Derivation of the differential first order kinetic equation}

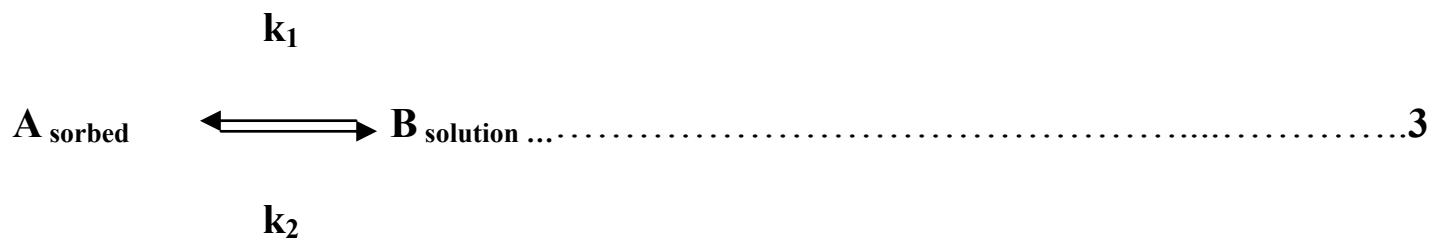

Where $\mathbf{A}$ is the concentration of species sorbed or encapsulated in the rock particulate matter. $\mathbf{B}$ is the concentration of extracted/released species at time $\mathbf{t}$. $\mathbf{k}_{\mathbf{1}}$ and $\mathbf{k}_{\mathbf{2}}$ are the first order reaction constants for the forward (release) and backward (sorption) reactions. The rate law for extracted species is

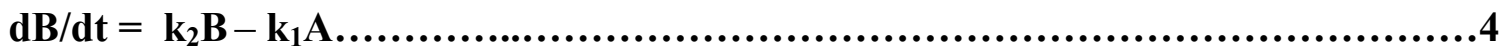

From reaction stoichiometry

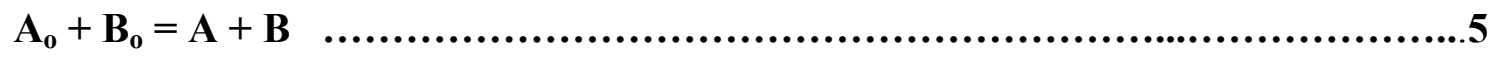

Where $\mathbf{A}_{\mathbf{0}}$ and $\mathbf{B}_{\mathbf{0}}$ are initial concentrations before extraction

On rearranging equation $\mathbf{5}$ to $\mathbf{A}=\mathbf{A}_{\mathbf{0}}+\mathbf{B}_{\mathbf{0}}-\mathbf{B}$ and substituting for $\mathbf{A}$ in $\mathbf{4}$

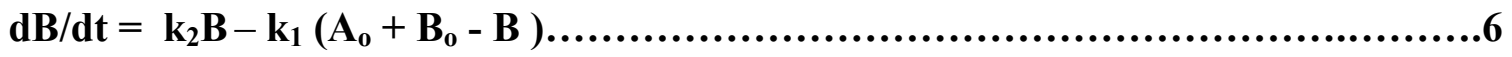

Rearranging equation 6

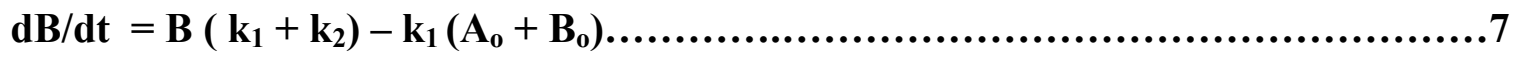

At equilibrium $\mathbf{d B} / \mathbf{d t}=\mathbf{0}, \mathbf{B}=\mathbf{B}_{\infty}$

Therefore equation 7 becomes

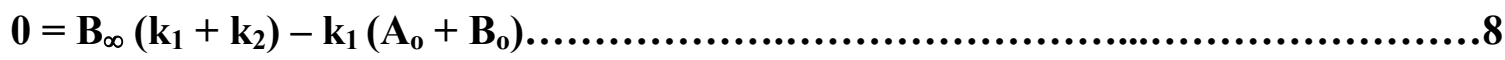

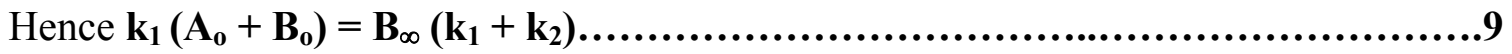

Substituting for $\mathbf{k}_{\mathbf{1}}\left(\mathbf{A}_{\mathbf{0}}+\mathbf{B}_{\mathbf{0}}\right)$ into equation 7

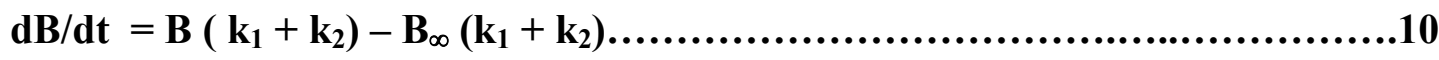




\section{Rearranging equation $\mathbf{1 0}$}

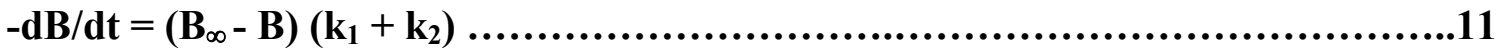

Upon integrating the first order differential equation (11) using the boundary $\mathrm{t}=0$ and $\mathrm{t}=$ t.

$\int \frac{d B}{\left(B_{\infty}-B\right)} \cdot=\int-\left(k_{1}+k_{2}\right) d t$

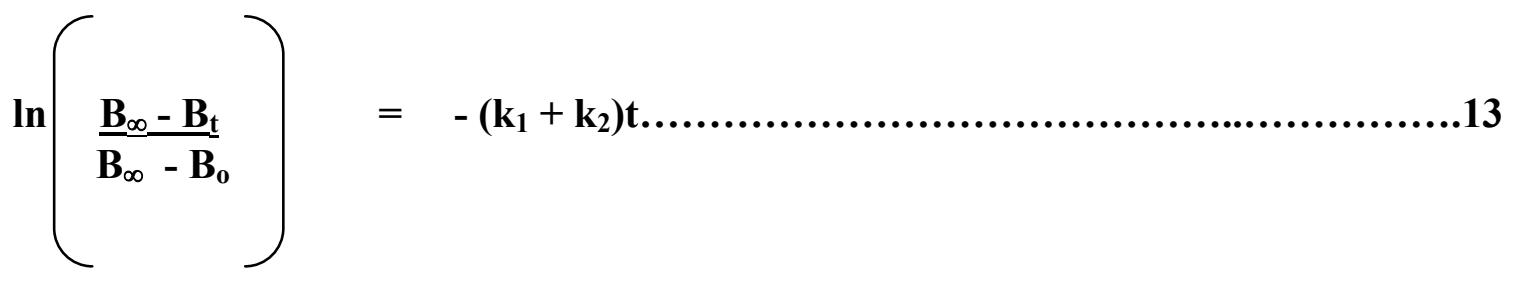

Since $\mathbf{B}_{\mathbf{0}}$ is negligible (amount extracted at time $\mathrm{t}=0$ ), we can write $\mathbf{B}_{\mathbf{0}}-\mathbf{B}_{\infty} \approx-\mathbf{B}_{\infty}$ and therefore equation 13 becomes

$\ln \left(1-B_{t} / B_{\infty}\right)=-\left(k_{1}+k_{2}\right) t$ .14

In general, the first order kinetic equation can be written as follows

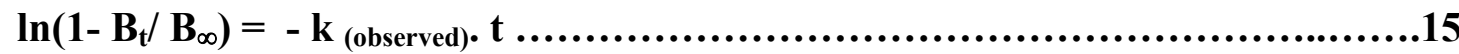

With respect to the build up of concentration of the desorbed species $\mathrm{B}, \mathbf{k}_{\mathbf{1}}$ is a negative slope and $\mathbf{k}_{\mathbf{2}}$ is a positive slope. Equation 14 clearly shows that there are two competing rate constants that bring about change in the sorption/desorption kinetics because $\mathbf{k}_{\text {observed }}=\mathbf{k}_{1}+\mathbf{k}_{2}$. Hence the overall observed reaction constant, $\mathbf{k}_{\text {observed }}$ for the reaction is the difference of the two opposing rate constants. For desorption to occur, the condition $\mathbf{k}_{2} \gg>\mathbf{k}_{1}$ is imperative otherwise sorption will become dominant. 
Appendix 1 B : Approximation of $B_{\infty}$ using the Kezdy-Swinebourne method ${ }^{30}$

From the 1 st order kinetic equation above

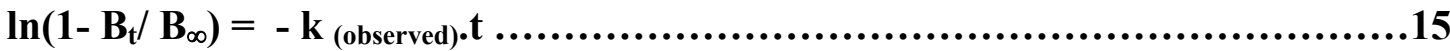

After an appropriate temporal variation $\mathbf{x}$ from time t, (x was determined to be 40

minutes, which represents the time at which more the $75 \%$ of the As and Se was leached out from the pulverized rock) the concentration of released species is $\mathbf{B}_{\mathbf{t}+\mathbf{x}}$. It is recommended that $\mathbf{x}$ should $2 \sim 3$ times the half-life of the total extraction procedure.

Hence the first order kinetic equation for the time $\mathrm{t}+\mathrm{x}$ becomes

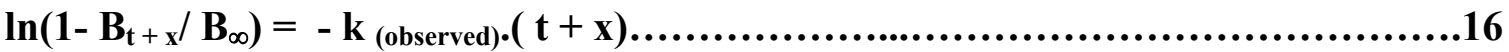

Invoking exp function on both sides of equations 15 and 16 we obtain,

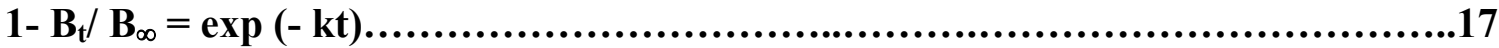

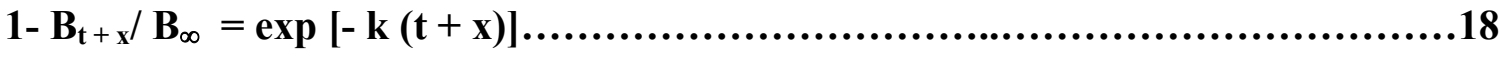

Rearranging equations 17 and 18

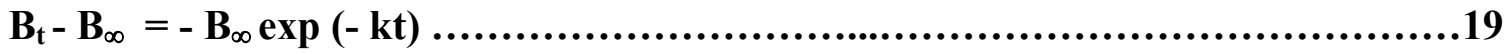

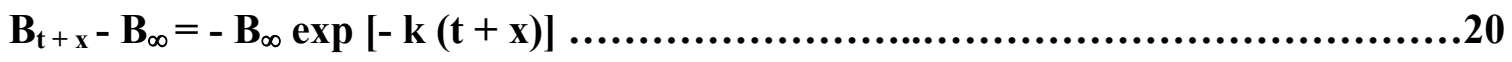

Dividing equation 19 by 20

$\underline{B}_{\underline{t}}-\underline{B}_{\infty}=\underline{B}_{\infty} \underline{\exp (-\mathbf{k t})}$

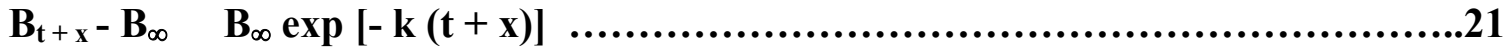

Simplifies to

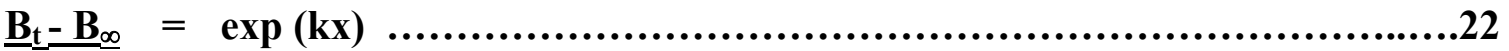

$\mathbf{B}_{t+\mathbf{x}}-\mathbf{B}_{\infty}$

Solving for $\mathbf{B}_{\mathbf{t}}$

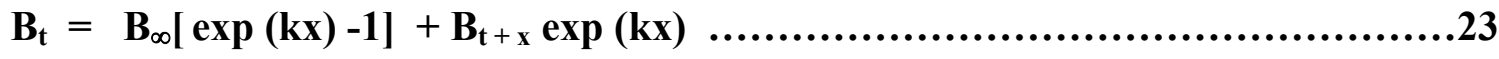

A plot of $\mathbf{B}_{\mathbf{t}} \mathbf{v s .} \mathbf{B}_{\mathbf{t}+\mathbf{x}}$ gives a linear plot with a slope equal to exp (kx). Since at the end 
point $\mathbf{B}_{\mathbf{t}}=\mathbf{B}_{\mathbf{t}+\mathbf{x}}=\mathbf{B}_{\infty}$, the intersection of the line through the data points with $45^{\circ}$ line $(y=x)$ gives the value of $\mathbf{B}_{\infty}$. Hence the value of $\mathbf{B}_{\infty}$ can be extrapolated from the graph. 


\section{Appendix 1 C}

\section{$\mathrm{X}$ ray diffraction analysis of rocks}

1. Run sample and obtain a diffractogram,

2. The presence of a $10 \AA$ peak indicates the presence of illite

3. The presence of a $7 \AA$ peak without a $14 \AA$ peak indicates the presence of Kaolinite. However having a $7 \AA$ peak together with a $14 \AA$ peak does not necessarily mean the presence of Kaolinite because the $7 \AA$ peak could result from second order diffraction lines( $n=2$ in the Bragg diffraction equation). Some further sample treatment are required to ascertain the presence of Kaolin.

4. Glycolation: Glycolation is used to identify the presence of montmorillonite and it involves the treatment of the sample with ethylene glycol either as a vapor or in an aqueous solution. Montmorillonite has easily accessible intersheet space and ethylene glycol will enter into the internal spacing. Because ethylene glycol is larger that water molecules the interplanner distance is increased upon the entry of ethylene glycol to $17 \AA$. The sample is then rescanned to check for the shifting of the original $14 \AA$ peak to a $17 \AA$ one. If the $14 \AA$ peak shifts to a larger spacing the sample contains a mixture of clays. The relative abundance of montmorillonite is estimated by the amount shifted from 14 to $17 \AA$.

5. After glycolation, if the $14 \AA$ peak persists the glycolated slide heated at $350^{\circ} \mathrm{C}$ for 12 hours and then rescanned. The persistence of the $14 \AA$ peak after thermal treatment confirms the presence of chlorite. Dioctahedral Vermiculite is identified if the peak shifts to $12 \AA$ with an overall decrease in intensity. If the $14 \AA$ peak 
disappears completely then the clay mineral is identified as trioctahedral vermiculite.

6. If the $14 \AA$ peak persists, the slide is heated at $350^{\circ} \mathrm{C}$ for 12 hours and then rescanned. If neither $14 \AA$ peak nor $3.54 \AA$ peak $(n=3)$ peaks are affected (change in intensity and shifting), results confirm the presence of Mg-chlorite. If only the $14 \AA$ peak decreases in intensity then Fe-chlorite is confirmed. Disappearance of the $14 \AA$ peak and the emergence of a 10-11 $\AA$ broad peak confirms the presence of dioctahedral vermiculite.

7. The $17 \AA$ peak from montmorillonite (step 4) will shift to $9.5 \AA$. All $7 \AA$ peaks due to Kaolinite will disappear.

8. The minerals illite and kaolinite are identified based on the diffraction analysis

9. The quantitation of illite, kaolinite, chlorite plagioclases and feldspar was done through Rietveld method utilizing a $\mathrm{ZnO}$ internal standard ${ }^{146}$. 

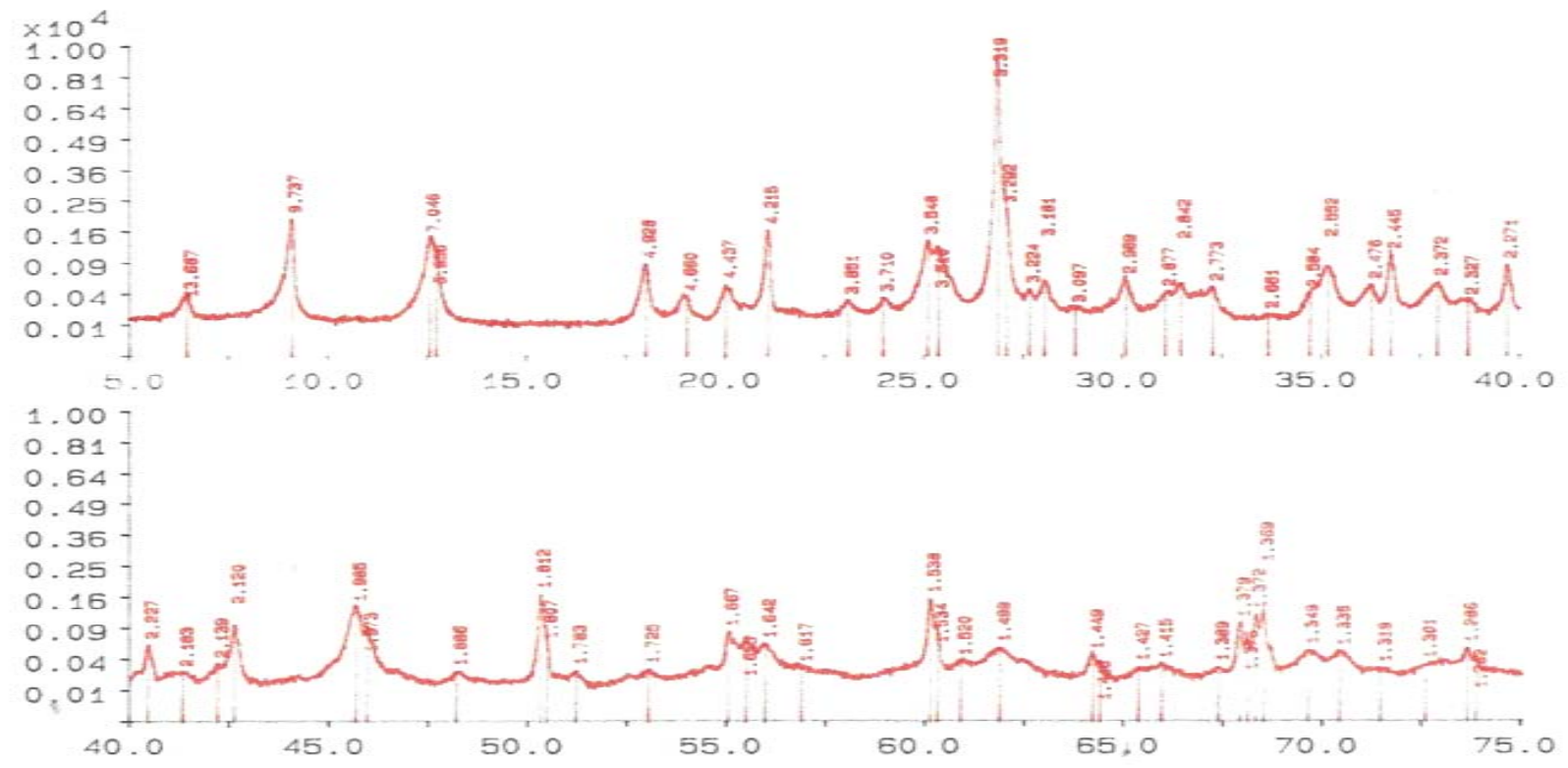

Figure 63: A diffractogram for an untreated clay sample ${ }^{131}$. 


\begin{tabular}{|l|l|l|l|l|}
\cline { 2 - 5 } \multicolumn{1}{c|}{} & \multicolumn{4}{c|}{ Reflection line ( Á) } \\
\hline Reflection order & $1^{0}$ & $2^{0}$ & $3^{0}$ & $4^{0}$ \\
\hline Anorthite ( Ca plagioclase) & 3.20 & $3.18_{9}$ & $4.04_{8}$ & $3.75_{8}$ \\
\hline Albite ( Na plagioclase) & 3.18 & $3.75_{3}$ & $3.21_{3}$ & $4.04_{2}$ \\
\hline Orthoclase (K- feldspar) & 3.31 & $3.77_{8}$ & $4.22_{7}$ & $3.24_{7}$ \\
\hline Quartz & 3.34 & $4.26_{2}$ & $1.82_{1}$ & $2.46_{1}$ \\
\hline Illite & 10.3 & $4.49_{9}$ & 2.57 & 3.69 \\
\hline Chlorite( Mg-Clinochlore) & 7.12 & $14.2_{7}$ & $3.56_{5}$ & $4.75_{4}$ \\
\hline Kaolinite & 7.17 & $1.49_{9}$ & $3.58_{8}$ & $1.62_{7}$ \\
\hline
\end{tabular}

Table 20 : Some reflection lines used in semi-quantitative analysis of rocks using XRD spectrometer ${ }^{139}$ 
Appendix 1 D: Results from secondary PCA

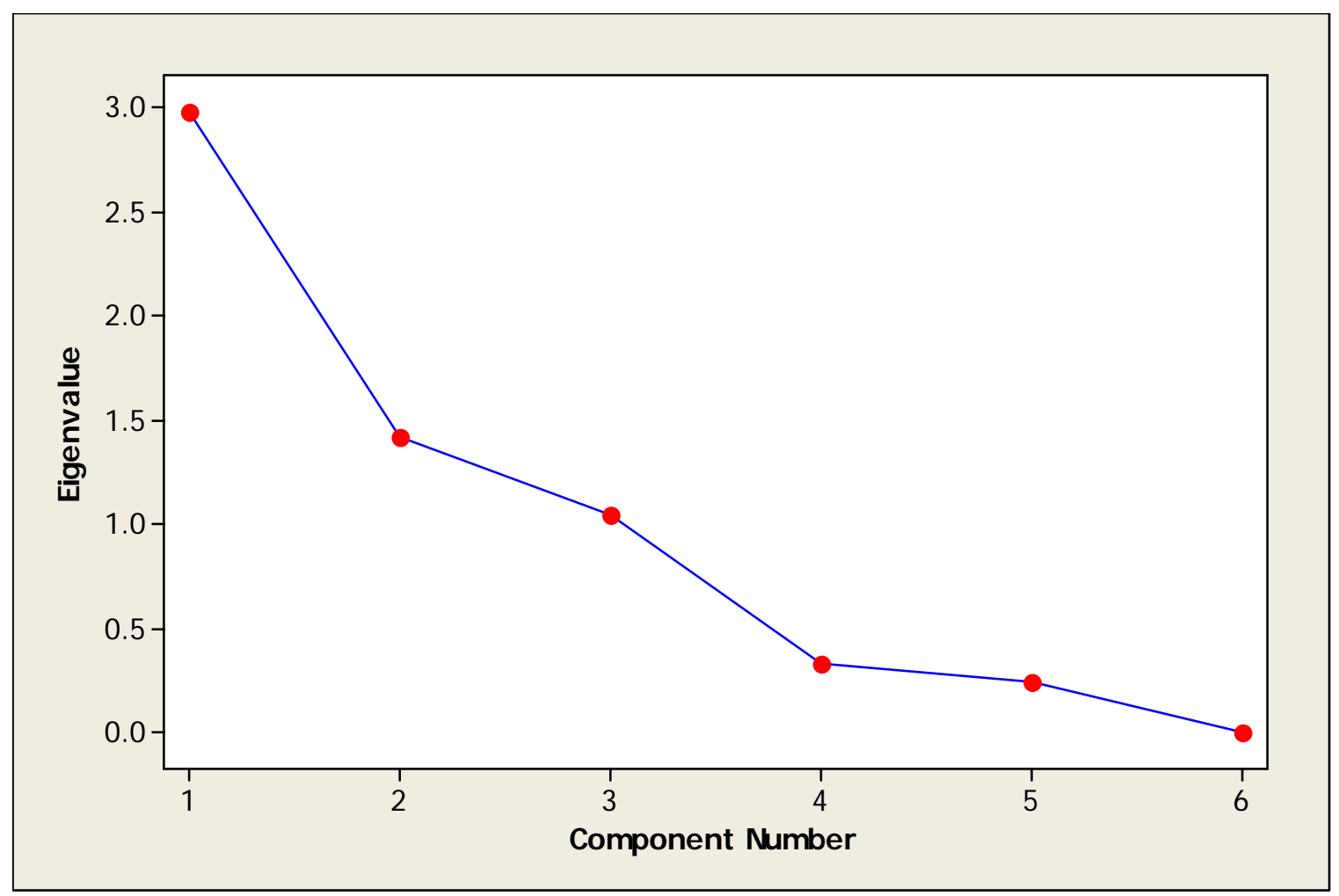

Figure 64: A scree plot for the secondary principal component analysis 


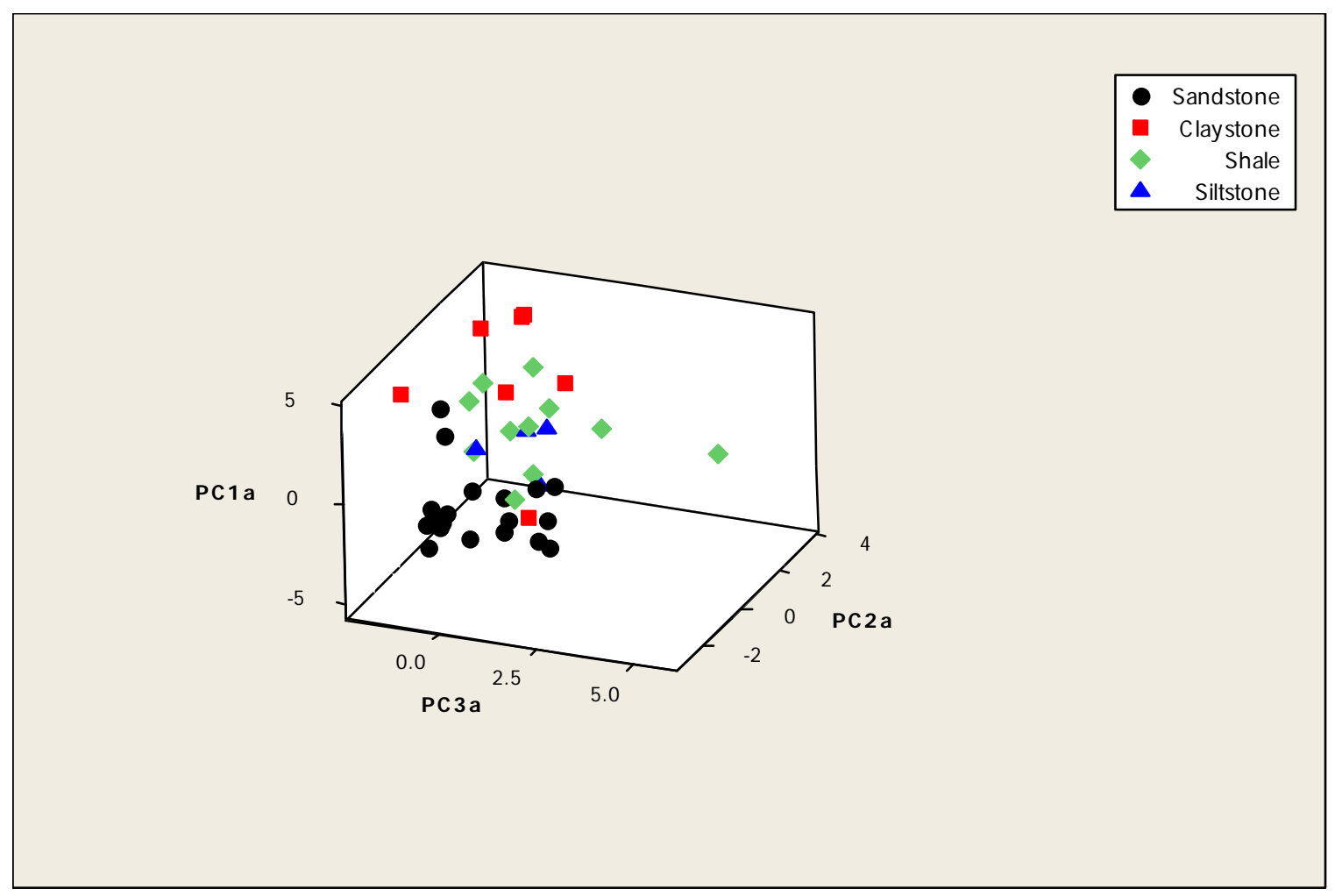

Figure 65 : A three dimensional plot of the secondary PCs. 


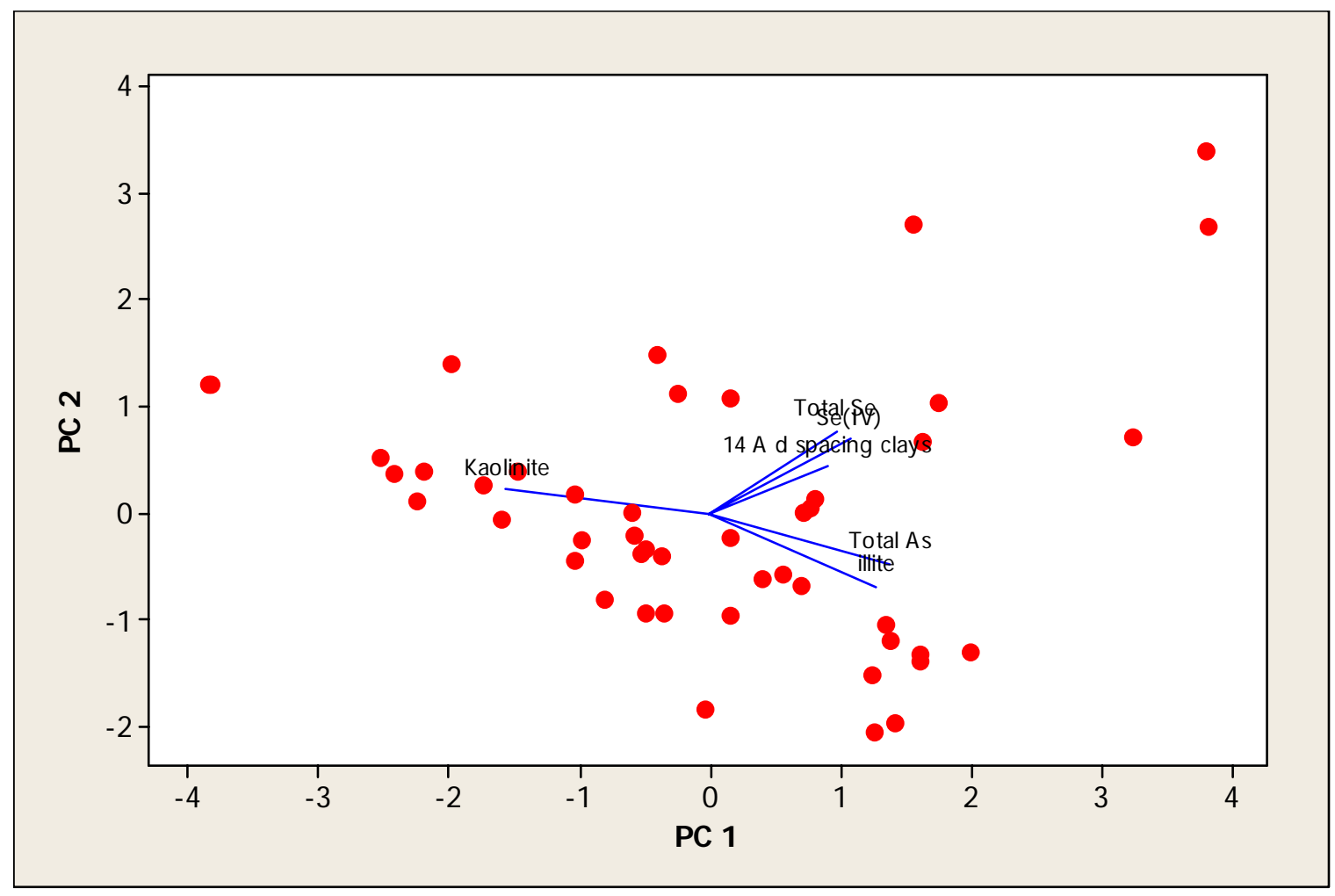

Figure 66: A biplot for the secondary PCA. 


\begin{tabular}{|c|c|c|c|c|c|c|}
\hline Variable & PC1 & PC2 & PC3 & PC4 & PC5 & PC6 \\
\hline \% Illite & 0.427 & -0.489 & $\odot .222$ & -0.215 & 0.458 & 0.522 \\
\hline \% Kaolinite & -0.524 & 0.152 & 0.350 & 0.119 & -0.264 & 0.704 \\
\hline$\%$ Chlorite & 0.303 & 0.308 & -0.752 & 0.060 & -0.111 & 0.482 \\
\hline Total Se & 0.325 & 0.543 & 0.343 & $\odot .579$ & 0.384 & 0.000 \\
\hline Total As & 0.464 & -0.335 & 0.183 & $\odot .404$ & -0.690 & 0.000 \\
\hline $\operatorname{Se}(\mathrm{IV})$ & 0.360 & 0.485 & 0.334 & -0.662 & -0.292 & $-0.0 \odot \odot$ \\
\hline Eigenvalue & 2.9773 & 1.4220 & 1.0394 & ๑. 3263 & 0.2350 & $-\odot .000 \odot$ \\
\hline ion & 0.496 & 0.237 & 0.173 & 0.054 & 0.039 & -0.000 \\
\hline Cumula & 0.496 & 0.733 & 0.906 & $\odot .961$ & $1.00 \odot$ & 1.000 \\
\hline
\end{tabular}

Table 21: Secondary principal components and their respective eigenvalues. 
Cited References Cited

(1) Hartman, K. J.; Kaller, M. D.; Howell, J. W.; Sweka, J. A. Hydrobiologia 2005, 532, 91-102.

(2) Dreher, G. B.; Finkelman, R. B. Environmental Geology and Water Sciences 1992, 19, 155-167.

(3) Coleman, L.; Bragg, L. J.; Finkelman, R. B. Environmental Geochemistry and Health 1993, 15, 215-227.

(4) Lussier, C.; Veiga, V.; Baldwin, S. Environmental Geology 2003, 44, 905-913.

(5) USEPA $h$ http://www.epa.gov/safewater/contaminants/dw_contamfs/selenium.html 2006.

(6) USEPA http://www.epa.gov/waterscience/criteria/wqctable/index.html\#R 2008.

(7) Bryant, G.; McPhilliamy, S.; Childers, H.; WVGES, 2002.

(8) Sylvester, P.; Westerhoff, P.; Mooller, T.; Badruzzaman, M.; Boyd, O. Environmental Engineering Science 2007, 24, 104-112.

(9) Zawislanski, P. T.; Benson, S. M.; Terberg, R.; Borglin, S. E. Environmental Science \& Technology 2003, 37, 2415-2420.

(10) Pyrzynska, K. Analytical Sciences 1998, 14, 479-483.

(11) Mountainjusticesummer.com. What is Mountain Top Removal Mining? http://www.mountainjusticesummer.org/facts/steps.php

2005. (accessed 08/01/2008)

(12) Caskey, A. From the Sky: Mountaintop Removal/Valley Fill Coal Mining. http://web.mac.com/antrim16/Antrim/aerial_mtr.html

2007. (accessed 08/01/2008)

(13) Ranjard, L.; Prigent-Combaret, C.; Nazaret, S.; Cournoyer, B. Journal of Bacteriology 2002, 184, 3146-3149.

(14) Nelson, D. C.; Casey, W. H.; Sison, J. D.; Mack, E. E.; Ahmad, A.; Pollack, J. S. Geochimica Et Cosmochimica Acta 1996, 60, 3531-3539.

(15) Krupka, K. M.; Serne, R. J.; Kaplan, D. I. Pacific Northwest National Laboratory, Richland. WA.http://www.pnl.gov/main/publications/external/technical_reports 2004.

(16) Maier KJ and Knight, A. W.; Archives of environmental contamination and toxicology 1993, 25, 365.

(17) Hsia, T. H.; Lo, S. L.; Lin, C. F.; Lee, D. Y. Colloids and Surfaces aPhysicochemical and Engineering Aspects 1994, 85, 1-7.

(18) Stolz, J. F.; Oremland, R. S. Fems Microbiology Reviews 1999, 23, 615-627.

(19) Smedley, P. L.; Kinniburgh, D. G. Applied Geochemistry 2002, 17, 517-568.

(20) Lemly, A. D.; Finger, S. E.; Nelson, M. K. Environmental Toxicology and Chemistry 1993, 12, 2265-2279.

(21) Ohlendorf, H. M.; Hoffman, D. J.; Saiki, M. K.; Aldrich, T. W. Science of the Total Environment 1986, 52, 49-63.

(22) Lemly, A. D. Aquatic Toxicology 2002, 57, 39-49.

(23) Lemly, A. D. Aquatic Toxicology 1993, 27, 133-158.

(24) Liao, C. M.; Chiang, K. C.; Tsai, J. W. Environ Toxicol 2006, 21, 154-165.

(25) Kithome, M.; Paul, J. W.; Lavkulich, L. M.; Bomke, A. A. Soil Science Society of America Journal 1998, 62, 622-629.

(26) Goh, K. H.; Lim, T. T. Chemosphere 2004, 55, 849-859. 
(27) Shimizu, K.; Hasegawa, K.; Nakamuro, Y.; Kodama, T.; Komarneni, S. Journal of Materials Chemistry 2004, 14, 1031-1035.

(28) Aharoni, C.; Sparks, D. L.; Levinson, S.; Ravina, I. Soil Science Society of America Journal 1991, 55, 1307-1312.

(29) Sparks, D. L. Soil Physical Chemistry, Second ed.; CRC Press, 1998.

(30) Espenson, J. H. Chemical kinetics and reaction mechanisms, 1 st ed.; McgrawHill, 1981.

(31) Rieuwerts, J. S.; Thornton, I.; Farago, M. E.; Ashmore, M. R. Chemical Speciation and Bioavailability 1998, 10, 61-75.

(32) Lahermo, P.; Alfthan, G.; Wang, D. J Environ Pathol Toxicol Oncol 1998, 17, 205-216.

(33) Myneni, S. C. B.; Tokunaga, T. K.; Brown, G. E. Science 1997, 278, 1106-1109.

(34) Korfali, S. I.; Davies, B. E. Environ Geochem Health 2005, 27, 385-395.

(35) Tokunaga, T. K.; Sutton, S. R.; Bajt, S.; Nuessle, P.; Shea-McCarthy, G. Environmental Science \& Technology 1998, 32, 1092-1098.

(36) Tokunaga, T. K.; Pickering, I. J.; Brown, G. E. Soil Science Society of America Journal 1996, 60, 781-790.

(37) Lejeune, K.; Galbraith, H.; Lipton, J.; Kapustka, L. A. Ecotoxicology 1996, 5, 297-312.

(38) Terry, N.; Zayed, A. M.; de Souza, M. P.; Tarun, A. S. Annual Review of Plant Physiology and Plant Molecular Biology 2000, 51, 401-432.

(39) Fujita, M.; Ike, M.; Hashimoto, R.; Nagkawa, T.; Yamaguchi, K.; Soda, S. Chemosphere 2005, 58, 705-714.

(40) Tokunaga, T. K.; Brown, G. E.; Pickering, I. J.; Sutton, S. R.; Bait, S. Environmental Science \& Technology 1997, 31, 1419-1425.

(41) Lin, Z.; Puls, R. W. Environmental Geology 2000, 39, 753-759.

(42) Mohan, D.; Pittman, C. U. Journal of Hazardous Materials 2007, 142, 1-53.

(43) Gimenez, J.; Martinez, M.; de Pablo, J.; Rovira, M.; Duro, L. Journal of Hazardous Materials 2007, 141, 575-580.

(44) Thanabalasingam, P.; Pickering, W. F. Environmental Pollution Series BChemical and Physical 1986, 12, 233-246.

(45) Trivedi, P.; Axe, L. Environmental Science \& Technology 2000, 34, 2215-2223.

(46) Su, C. M.; Suarez, D. L. Soil Science Society of America Journal 2000, 64, 101111.

(47) Manning, B. A.; Goldberg, S. Environmental Science \& Technology 1997, 31, 2005-2011.

(48) Scott, M. J.; Morgan, J. J. Environmental Science \& Technology 1995, 29, 18981905.

(49) Wrobel, K.; Wrobel, K.; Caruso, J. A. Analytical and Bioanalytical Chemistry 2005, 381, 317-331.

(50) Gao, S.; Tanji, K. K.; Dahlgren, R. A.; Ryu, J.; Herbel, M. J.; Higashi, R. M. Chemosphere 2007, 69, 585-594.

(51) Baldwin, S. A.; Hodaly, A. H. Water Quality Research Journal of Canada 2003, 38, 483-497. 
(52) Watzin, M. C.; McIntosh, A. W.; Brown, E. A.; Lacey, R.; Lester, D. C.; Newbrough, K. L.; Williams, A. R. Environmental Toxicology and Chemistry 1997, 16, 2125-2135.

(53) Burton, A. Environmental Toxicology and Chemistry 1991, 10, 1585-1627.

(54) USEPA EPA 823-R-97-006 1997, 1-3.

(55) Burton, A. Limnology 2002, 3, 65-75.

(56) Tessier A, C. P. Analytical Chemistry 1979, 51, 844-851.

(57) Olivas, R. M.; Donard, O. F. X.; Camara, C.; Quevauviller, P. Analytica Chimica Acta 1994, 286, 357-370.

(58) Perez-Cid, B.; Bola, C. International Journal of Environmental Analytical Chemistry 2001, 81, 101-115.

(59) Mossop, K. F.; Davidson, C. M. Analytica Chimica Acta 2003, 478, 111-118.

(60) Van Herreweghe, S.; Swennen, R.; Vandecasteele, C.; Cappuyns, V. Environmental Pollution 2003, 122, 323-342.

(61) Ochsenkuhn-Petropoulou, M.; Tsopelas, F. Analytica Chimica Acta 2002, 467, 167-178.

(62) Seby, F.; Gautier, M. P.; Lespes, G.; Astruc, M. Science of the Total Environment 1997, 207, 81-90.

(63) Pizarro, J.; Rubio, M. A.; Castillo, X. Journal of the Chilean Chemical Society 2003, 48, 45-50.

(64) Bujdos, M.; Mul'ova, A.; Kubova, J.; Medved', J. Environmental Geology 2005, 47, 353-360.

(65) Zhang, Y. Q.; Frankenberger, W. T. International Journal of Environmental Analytical Chemistry 2003, 83, 315-326.

(66) Tan, J. A.; Zhu, W. Y.; Wang, W. Y.; Li, R. B.; Hou, S. F.; Wang, D. C.; Yang, L. S. Science of the Total Environment 2002, 284, 227-235.

(67) Sharmasarkar, S.; Vance, G. F. Journal of Environmental Quality 2002, 31, 15161521.

(68) Lu, C. Y.; Yan, X. P. Electrophoresis 2005, 26, 155-160.

(69) Davidson, C. M.; Delevoye, G. Journal of Environmental Monitoring 2001, 3, 398-403.

(70) Ipolyi, I.; Brunori, C.; Cremisini, C.; Fodor, P.; Macaluso, L.; Morabito, R. Journal of Environmental Monitoring 2002, 4, 541-548.

(71) de Leon, C. A. P.; DeNicola, K.; Bayon, M. M.; Caruso, J. A. Journal of Environmental Monitoring 2003, 5, 435-440.

(72) Greenway, G. M.; Song, Q. J. Journal of Environmental Monitoring 2002, 4, 950955.

(73) Luque-Garcia, J. L.; de Castro, L. Trac-Trends in Analytical Chemistry 2003, 22, 41-47.

(74) He, Z. Q.; Traina, S. J.; Weavers, L. K. Environmental Science \& Technology 2007, 41, 779-784.

(75) Brunori, C.; Ipolyi, I.; Macaluso, L.; Morabito, R. Analytica Chimica Acta 2004, 510, 101-107.

(76) Suslick, K. S. Scientific American 1989, 260, 80-86.

(77) Perez-Cid, B.; Lavilla, I.; Bendicho, C. International Journal of Environmental Analytical Chemistry 1999, 73, 79-92. 
(78) Tse, K. K. C.; Lo, S. L. Water Research 2002, 36, 284-290.

(79) Mierzwa, J.; Adeloju, S. B.; Dhindsa, H. S. Analytical Sciences 1997, 13, 189 193.

(80) Arruda, S. C. C.; Rodriguez, A. P. M.; Arruda, M. A. Z. Journal of the Brazilian Chemical Society 2003, 14, 470-474.

(81) Joyce, E.; Phull, S. S.; Lorimer, J. P.; Mason, T. J. Ultrasonics Sonochemistry 2003, 10, 315-318.

(82) Ince, N. H.; Belen, R. Environmental Science \& Technology 2001, 35, 1885-1888.

(83) Sparks, D. L. Kinetics of Soil Chemical Processes; Academic press, San Diego, CA., 1989.

(84) Atkins, P.; de Paula, J. Physical Chemistry, 7 th ed.; W.H. Freeman Company, New York, 2002.

(85) Atkins, P. Physical Chemistry, 4th ed.; W.H. Freeman Company, New York, 1990.

(86) Mason, T. J.; Lorimer, J. P.; Bates, D. M. Ultrasonics 1992, 30, 40-42.

(87) Contamine, R. F.; Wilhelm, A. M.; Berlan, J.; Delmas, H. Ultrasonics Sonochemistry 1995, 2, S43-S47.

(88) Kimura, T.; Sakamoto, T.; Leveque, J. M.; Sohmiya, H.; Fujita, M.; Ikeda, S.; Ando, T. Ultrasonics Sonochemistry 1996, 3, S157-S161.

(89) Skopp, J. Journal of Environmental Quality 1986, 15, 205-213.

(90) Wen, B.; Shan, X. Q.; Lin, J. M.; Tang, G. G.; Bai, N. B.; Yuan, D. A. Soil Science Society of America Journal 2002, 66, 1198-1206.

(91) Barry, D. A.; Parlange, J. Y.; Hensley, P. J. International Journal for Numerical and Analytical Methods in Geomechanics 1993, 17, 243-254.

(92) Huertas, F. J.; Chou, L.; Wollast, R. Geochimica Et Cosmochimica Acta 1999, 63, 3261-3275.

(93) Gu, B. H.; Schmitt, J.; Chen, Z. H.; Liang, L. Y.; Mccarthy, J. F. Environmental Science \& Technology 1994, 28, 38-46.

(94) Shiowatana, J.; Tantidanai, N.; Nookabkaew, S.; Nacapricha, D. Journal of Environmental Quality 2001, 30, 1195-1205.

(95) Chomchoei, R.; Shiowatana, J.; Pongsakul, P. Analytica Chimica Acta 2002, 472, 147-159.

(96) Sabbah, I.; Ball, W. P.; Young, D. F.; Bouwer, E. J. Environmental Engineering Science 2005, 22, 350-366.

(97) Zhang, P. C.; Sparks, D. L. Environmental Science \& Technology 1990, 24, 18481856.

(98) Quaghebeur, M.; Rate, A.; Rengel, Z.; Hinz, C. Journal of Environmental Quality 2005, 34, 479-486.

(99) Jenkins, G.; Schaer, N.; WVDEP, 2005.

(100) Liu, G.; Zhang, Y.; Qi, C.; Zheng, L.; Chen, Y.; Peng, Z. Environ Monit Assess 2006, 2007, 99-103.

(101) Liu, G.; Zhang, Y.; Qi, C.; Zheng, L.; Chen, Y.; Peng, Z. Environ Monit Assess 2007, 133, 99-103.

(102) Peak, D.; Sparks, D. L. Environmental Science \& Technology 2002, 36, 1460 1466. 
(103) He, Z. Q.; Traina, S. J.; Bigham, J. M.; Weavers, L. K. Environmental Science \& Technology 2005, 39, 1037-1044.

(104) Kulp, T. R.; Pratt, L. M. Geochimica Et Cosmochimica Acta 2004, 68, 36873701.

(105) Velinsky, D. J.; Cutter, G. A. Analytica Chimica Acta 1990, 235, 419-425.

(106) Manjanna, J.; Venkateswaran, G.; Kumbhar, A. G. Bulletin of Electrochemistry 2003, 19, 541-546.

(107) Farmer, A. D.; Collings, A. F.; Jameson, G. J. International Journal of Mineral Processing 2000, 60, 101-113.

(108) Linge, K. L.; Oldham, C. E. J Environ Qual 2002, 31, 822-828.

(109) Stolz, J. E.; Basu, P.; Santini, J. M.; Oremland, R. S. Annual Review of Microbiology 2006, 60, 107-130.

(110) Duzgoren-Aydin, N. S.; Aydin, A.; Malpas, J. Catena 2002, 50, 17-41.

(111) Islam, M. R.; Peuraniemi, V.; Aario, R.; Rojstaczer, S. Applied Geochemistry 2002, 17, 885-902.

(112) Tourliere, B.; Perrin, J.; Le Berre, P.; Pasquet, J. F. Journal of Applied Geophysics 2003, 53, 91-102.

(113) Long, D. G. F. Applied Clay Science 2000, 16, 97-115.

(114) Cravero, F.; Dominguez, E.; Iglesias, C. Applied Clay Science 2001, 18, 157-172.

(115) Al-Hamdan, A. Z.; Reddy, K. R. Adsorption-Journal of the International Adsorption Society 2005, 11, 529-546.

(116) Arias, M.; Barral, M. T.; Da Silva-Carvalhal, J.; Mejuto, J. C.; Rubinos, D. Clay Minerals 2004, 39, 35-45.

(117) Wen, H. J.; Carignan, J.; Qlu, Y. H.; Liu, S. R. Environmental Science \& Technology 2006, 40, 1126-1132.

(118) Fernandez, M. G. C.; Palacios, M. A.; Camara, C. Analytica Chimica Acta 1993, 283, 386-392.

(119) Arai, Y.; Sparks, D. L.; Davis, J. A. Environmental Science \& Technology 2005, 39, 2537-2544.

(120) Cullen, W. R.; Reimer, K. J. Chemical Reviews 1989, 89, 713-764.

(121) Tschapek, M.; Tcheichvili, L.; Wasowski, C. Clay minerals 1974, 10, 219-229.

(122) Johnson, T. M. Chemical Geology 2004, 204, 201-214.

(123) Shaker, A. M. Journal of Colloid and Interface Science 1996, 180, 225-231.

(124) Tan, T. T. Y.; Beydoun, D.; Amal, R. Journal of Physical Chemistry B 2003, 107, 4296-4303.

(125) Redman, A. D.; Macalady, D. L.; Ahmann, D. Environ Sci Technol 2002, 36, 2889-2896.

(126) Satterberg, J.; Arnarson, T. S.; Lessard, E. J.; Keil, R. G. Marine Chemistry 2003, 81, 11-18.

(127) Simoneit, B. R. Anat Rec 2002, 268, 186-195.

(128) Noffke, N.; Geddes, G.; Klenke, T. Earth-Science Reviews 2003, 62, 163.

(129) Faure, G. Principles and applications of Inorganic geochemistry, 1 st ed.; Macmillian, 1991.

(130) Plancon, A. American Mineralogist 2002, 87, 1672-1677.

(131) Renton, J. J., 2007.

(132) Ringner, M. Nat Biotechnol 2008, 26, 303-304. 
(133) Faria, R.; Duncan, J. C.; Brereton, R. G. Polymer Testing 2007, 26, 402-412.

(134) Astel, A.; Tsakovski, S.; Barbieri, P.; Simeonov, V. Water Res 2007, 41, 45664578.

(135) Astel, A.; Tsakovski, S.; Simeonov, V.; Reisenhofer, E.; Piselli, S.; Barbieri, P. Anal Bioanal Chem 2008, 390, 1283-1292.

(136) Pardo, R.; Vega, M.; Deban, L.; Cazurro, C.; Carretero, C. Analytica Chimica Acta 2008, 606, 26-36.

(137), 545, 1.

(138) Gabriel, K. R. Biometrika 1971, 58, 453-457.

(139) ICDD Powder Diffraction File. Alphabetical indexes. Inorganic phases, 1997.

(140) Asuero, A. G.; Sayago, A.; GonzÃ ;lez, A. G. Critical Reviews in Analytical Chemistry 2006, 36, 41 - 59.

(141) Vesper, D.; Roy, M.; Rhoads, C. J. International Journal of Coal Geology 2008, 73, 237.

(142) Dontsova, K. M.; Bigham, J. M. Soil Science Society of America Journal 2005, 69, 1026-1035.

(143) Kennedy, M. J.; Pevear, D. R.; Hill, R. J. Science 2002, 295, 657-660.

(144) Indraratne, S. P.; Goh, T. B.; Shindo, H. Geoderma 2007, 139, 314-320.

(145) Shannon, R. D. Acta Crystallographica 1976, A32, 751.

(146) Srodon, J.; Drits, V. A.; McCarty, D. K.; Hsieh, J. C. C.; Eberl, D. D. Clays and Clay Minerals 2001, 49, 514-528. 